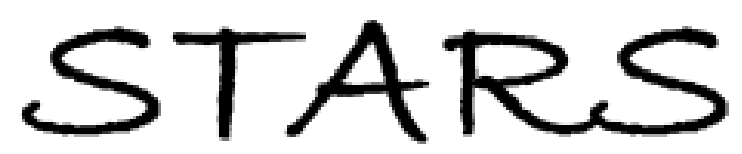

University of Central Florida

STARS

\title{
Effectiveness And Kinetics Of Ferrate As A Disinfectant For Ballast Water
}

Andrea L. Jessen

University of Central Florida

Part of the Environmental Engineering Commons

Find similar works at: https://stars.library.ucf.edu/etd

University of Central Florida Libraries http://library.ucf.edu

This Masters Thesis (Open Access) is brought to you for free and open access by STARS. It has been accepted for inclusion in Electronic Theses and Dissertations by an authorized administrator of STARS. For more information, please contact STARS@ucf.edu.

\section{STARS Citation}

Jessen, Andrea L., "Effectiveness And Kinetics Of Ferrate As A Disinfectant For Ballast Water" (2006). Electronic Theses and Dissertations. 6123.

https://stars.library.ucf.edu/etd/6123

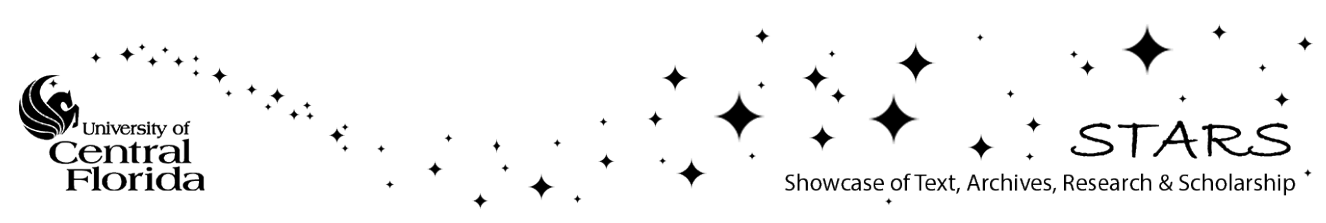




\title{
EFFECTIVENESS AND KINETICS OF FERRATE AS A DISINFECTANT FOR BALLAST WATER
}

\author{
by \\ ANDREA L. JESSEN \\ B.S. Bates College, 1985 \\ A thesis submitted in partial fulfillment of the requirements \\ for the degree of Master of Science \\ in the Department of Civil and Environmental Engineering \\ in the College of Engineering and Computer Science \\ at the University of Central Florida \\ Orlando, Florida
}

Summer Term

2006 


\begin{abstract}
The introduction of aquatic nuisance species (ANS) and bacterial pathogens from discharge of ballast water by sea-faring vessels is an ongoing problem that threatens ecosystems and human health. This study investigates the disinfecting capability of ferrate in a marine environment on several organisms listed in international standards for ballast water management. Organisms were grown in a saline solution and were treated with dosages of ferrate ranging from 0.25-5.0 $\mathrm{mg} / \mathrm{l}$. A ferrate dose of $5 \mathrm{mg} / \mathrm{l}$ resulted in almost complete kill for all organisms tested. Smaller dosages have also been very effective, particularly if all organic material from the nutrient broth used to cultivate them is removed by washing the cells with saline solution. Ferrate appears to act very quickly, with tailing occurring after about 5-15 minutes. Analyses of the data with the CT approach, the Chick-Watson and Hom's models, and an oxidant demand equation derived from equations recommended by the Water Environment Federation (WEF) are in good agreement that ferrate concentration is more important than contact time. The Hom's model appeared to most accurately represent the action of ferrate on these organisms. Salinity and $\mathrm{pH}$ did not adversely affect results, and regrowth was not a problem. Two measures to reduce clumping did not eliminate the observed tailing effect, suggesting a different mechanism for this phenomena. These preliminary tests indicate that ferrate could be a very effective disinfectant in the treatment of ballast water, and the short half-life of ferrate is an advantage, since the ballast water is subsequently released into the environment.
\end{abstract}


This thesis is dedicated to Jerry Lunde for his endless support, and to all my "best friends": Cypress, Sherman, Medley, Murphy, Kaboom!, Flannel, Turbo, and Chaos 


\section{ACKNOWLEDGMENTS}

Many thanks to Drs. Randall and Reinhart for their

guidance, patience, knowledge, and great insight.

Thanks also to Dr. Wanielista for acting as my third advisor on

short notice and for his helpful comments for revision of this thesis.

Funding for this study by Luke Daly of

Ferrate Treatment Technologies, Inc., in

Orlando, FL, is gratefully acknowledged.

Thanks also to Lucia Lettie for preparing ferrate

and offering advice. 


\section{TABLE OF CONTENTS}

LIST OF FIGURES ...................................................................................... VII

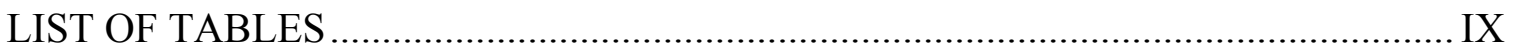

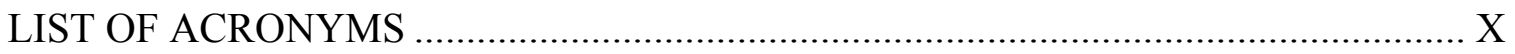

CHAPTER 1: GENERAL INTRODUCTION …....................................................... 1

CHAPTER 2: LITERATURE REVIEW .......................................................... 4

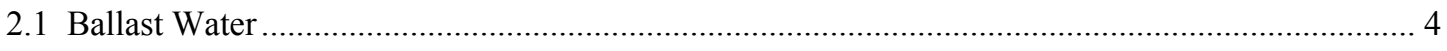

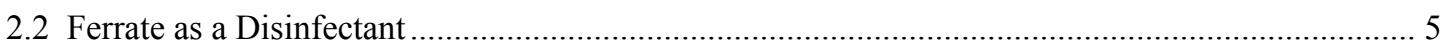

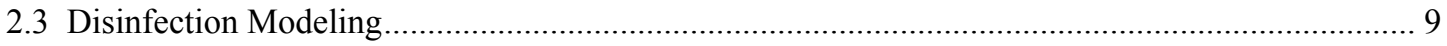

2.4 Mechanisms for Disinfection Kinetics Deviations ..................................................................... 14

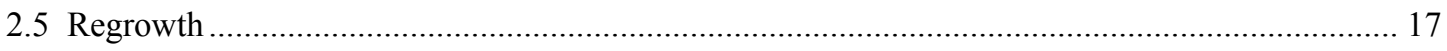

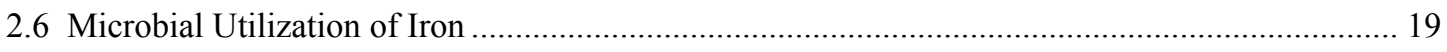

CHAPTER 3: RESULTS AND DISCUSSION ......................................................... 23

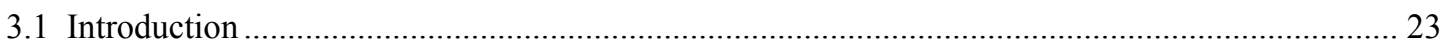

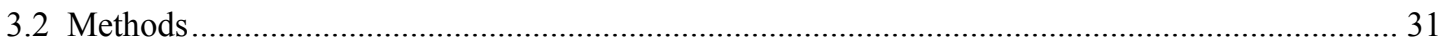

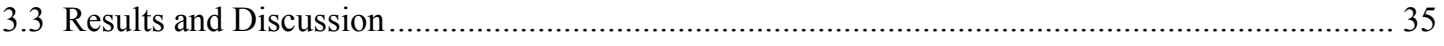

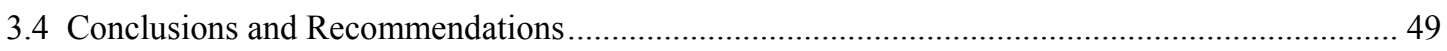

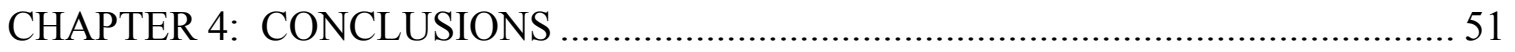

CHAPTER 5: RECOMMENDATIONS FOR FUTURE STUDY .............................. 53

APPENDIX A: EXPERIMENTAL OUTLINE AND OPTIMIZATION ....................... 56

APPENDIX B: SUMMARY GRAPHS OF DOSE RESPONSE CURVES FOR TEST

ORGANISMS TO FERRATE DISINFECTION …........................................ 67 
APPENDIX C: SAMPLE CALCULATIONS OF KINETIC MODEL CONSTANTS AND PH AND SALINITY EFFECTS ……………….................................... 71

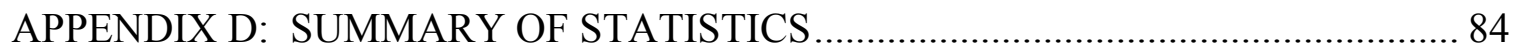

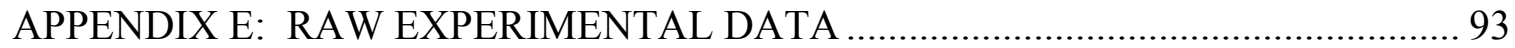

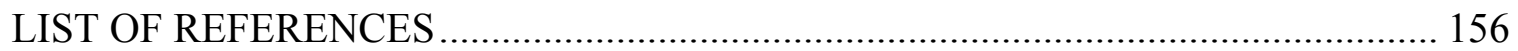




\section{LIST OF FIGURES}

Figure 1: Effect of Ferrate Dosage on E. coli MPN over Time: Results of One

Experiment.

Figure 2: Chick-Watson Analysis of E. coli Disinfection Experiment: Results of One

Experiment.

Figure 3: Effect of $\mathrm{pH}$ on Log Reduction of E. coli by $0.75 \mathrm{mg} / 1$ Ferrate (averages of 2 experiments).

Figure 4: Effect of Salinity on E. coli Mortality at Various Ferrate Dosages (averages of

2 experiments).

Figure 5: Effect of Initial K. pneumoniae Concentration on Effectiveness of a $1 \mathrm{mg} / \mathrm{l}$

Ferrate Dosage.

Figure 6: Effect of Low Speed Centrifugation to Remove Clumps................................ 46

Figure 7: Effect of Vigorous Vortexing to Reduce Potential Clumping. ....................... 46

Figure 8: Regrowth of E. coli after Ferrate Exposure (average of 2 experiments)........ 48

Figure A-1: Effect of Stirring on Ferrate Effectiveness on K. pneumoniae Mortality.... 63

Figure A-2: Effect of Vortexing on Ferrate Effectiveness on E. coli Mortality.............. 64

Figure A-3: Effect of Washing on E. coli Mortality by $0.5 \mathrm{mg} / 1$ Ferrate. ....................... 65

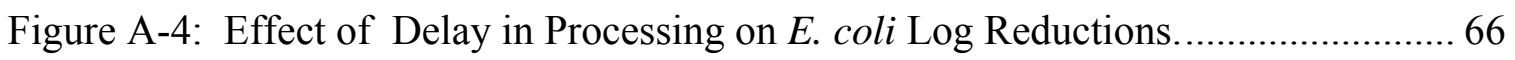

Figure B-1: Summary of Dose Response Curves for E. coli..................................... 68

Figure B-2: Summary of Dose Response Curves for K. pneumoniae ........................... 69

Figure B-3: Summary of Dose Response Curve for Enterococci.............................. 69

Figure B-4: Summary of Dose Response Curves for V. cholerae. .............................. 70

Figure C-1: Dosage-Response Curve for Sample Calculation. ................................... 73

Figure C-2: Log Reduction Graph for Sample Calculation......................................... 74

Figure C-3: Chick-Watson Analysis for Sample Calculation: Step 1......................... 74 
Figure C-4: Part 2 of Chick-Watson Analysis for Sample Calculation (4-log reduction).

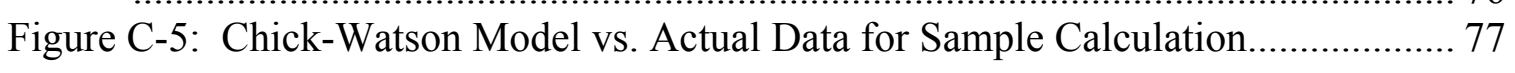

Figure C-6: Hom's Model vs. Actual Data for Sample Calculation............................. 78

Figure C-7: Graph for K. pneumoniae to Obtain Oxidant Demand Coefficients at 1 min. 


\section{LIST OF TABLES}

Table 1: Log reductions for test organisms for $5 \mathrm{mg} / 1$ ferrate dose for $5 \mathrm{~min}$ contact time.

Table 2: Coefficients of the two kinetic models for ferrate on the study organisms....... 37

Table 3: Coefficients for the oxidant demand equation for ferrate on the study organisms.

Table 4: Time (in minutes) to obtain a 4-log reduction of the organisms (extrapolated from experimental data using Hom's model coefficients).................................. 39

Table 5: Ratio of time required to obtain a 4-log reduction at 0.1 and $5.0 \mathrm{mg} /$ ferrate... 40

Table C-1: Contact Times Needed for Each Dosage (Part 2 of Chick-Watson Analysis)

Table C-2: Sample Calculations for Oxidant Demand Equation Parameters and Statistics.

Table C-3: Sample Calculations for Hypothesis Testing of Oxidant Demand Slope Comparisons.

Table D-1: Means and SDs for Chick-Watson and Hom's Coefficients....................... 85

Table D-2: Summary of pH Statistics for 0.75 mg/l Ferrate Dosage............................. 90

Table D-3: Summary of $\mathrm{pH}$ Statistics for $1.5 \mathrm{mg} / \mathrm{l}$ Ferrate Dosage............................... 91

Table D-4: Summary of Statistics for Anti-Clumping (AC) Measures. ......................... 92 


\section{LIST OF ACRONYMS}

\begin{tabular}{|c|c|}
\hline ANOVA & Analysis of Variance \\
\hline ANS & Aquatic nuisance species \\
\hline $\mathrm{AOC}$ & Assimilable organic content \\
\hline ATP & Adenosine triphosphate \\
\hline awcg & Area with confluent growth \\
\hline AWWA & American Water Works Association \\
\hline$\beta$ & The number of disinfectant-binding sites on an organism \\
\hline b & WEF experimental regression coefficient \\
\hline BRP & Bacterial regrowth potential \\
\hline $\mathrm{C}_{0}$ & Initial concentration of disinfectant \\
\hline $\mathrm{CFU}$ & Colony-forming unit \\
\hline $\mathrm{C}_{\mathrm{t}}$ & Concentration of disinfectant at time $t$ \\
\hline CT & Contact-time product \\
\hline d & WEF experimental regression coefficient \\
\hline DBP & Disinfection byproduct \\
\hline DOC & Dissolved organic content \\
\hline EPA & Environmental Protection Agency \\
\hline FAU & Formazin attenuation unit \\
\hline HNLC & High-nutrient, low-chlorophyll \\
\hline IMO & International Maritime Organization \\
\hline IO & Instant Ocean \\
\hline $\mathrm{k}, \mathrm{k}_{\mathrm{i}}$, and $\mathrm{k}_{2}$ & Experimental rate constants \\
\hline k' & Chick-Watson die-off constant \\
\hline $\mathrm{k}^{*}$ & Rate constant \\
\hline $\mathrm{K}_{\mathrm{d}}$ & Michaelis constant \\
\hline $\mathrm{m}$ & Coefficient of importance for time \\
\hline MEPC & Maritime Environment Protection Committee \\
\hline MPN & Most probable number \\
\hline$\eta$ & An efficiency factor \\
\hline $\mathrm{n}$ & Chick-Watson coefficient of dilution \\
\hline nd & Not done \\
\hline NB & Nutrient broth \\
\hline $\mathrm{N}_{0}$ & Initial bacterial concentration \\
\hline $\mathrm{N}_{\mathrm{t}}$ & Bacterial concentration at time $t$ \\
\hline NTU & Nephelometric turbidity unit \\
\hline $\mathrm{T}$ & An experimental constant \\
\hline THM & Trihalomethanes \\
\hline TOC & Total organic content \\
\hline UV & Ultraviolet \\
\hline WEF & Water Environment Federation \\
\hline WS & Working solution \\
\hline $\mathrm{x}$ & An empirical constant \\
\hline
\end{tabular}




\section{CHAPTER 1: GENERAL INTRODUCTION}

Aquatic invasive species (AIS) are non-native organisms that have been introduced into a body of water. If the organism has a detrimental impact on that water body, then it is also considered an aquatic nuisance species (ANS). Detrimental effects can include loss of biodiversity, reduction in numbers of native species, and disruption of the ecological balance, as well as impacts on commercial, agricultural, recreational, and municipal uses of the water body. Human health can also be impacted, particularly in the case of bacterial, fungal, and viral pathogens.

Ships have long been recognized as a source of ANS. In fact, anti-fouling paint was introduced years ago, in part to combat this problem, making ballast water the primary vector for ANS, including bacterial pathogens (US Environmental Protection Agency, USEPA, 2001). Vibrio epidemics in S. America, for example, have been traced to ballast water, and Latin American strains of $V$. cholerae, which lack hemolysin, have been identified in ballast water of cargo ships docked in the American Gulf Coast. The current method of disinfection of ballast water is mid-ocean ballast exchange, which is relatively ineffective (USEPA, 2001). International agencies, in particular the International Maritime Organization (IMO), are encouraging the development of new processes for ballast water treatment, and have established standards for testing of these processes. New techniques and equipment for the preparation of ferrate make it a promising, cost-effective, environmentally-friendly alternative to mid-ocean exchange and other disinfection processes. Ferrate is iron with a valence of +6 , making it an extremely powerful oxidant. As a result it inactivates and kills organisms. A company located in Orlando, Florida, Ferrate Treatment Technologies, LLC (“FTT”) has developed 
instrumentation to produce ferrate onboard vessels for immediate use as a ballast water disinfectant. Therefore, one objective of this study was to determine whether ferrate could meet the international standards for successful ballast water treatment, including final concentrations of less than $1 \mathrm{CFU} / \mathrm{ml}$ of Enterococci, less than $2.5 \mathrm{CFUs} / \mathrm{ml}$ of Escherichia coli, less than 1 CFU/100 mls of Vibrio cholerae, and an unspecified but measured endpoint for coliforms. To this end, pure cultures of Escherichia coli, Klebsiella pneumoniae, and V. cholerae, and a mixed culture of Enterococcus faecium and E. faecilis, were grown in saline solution to simulate ballast water, and were treated with dosages of ferrate ranging from $0.25-5.0 \mathrm{mg} / \mathrm{l}$.

Different models are used to describe disinfection kinetics. The CT approach, used commonly in drinking water regulations (AWWA, 1999), assumes that equal products of concentrations (C) and contact times (T) will result in equivalent log reductions. The ChickWatson law relates the survival rate of the target organism to the concentration of disinfectant and a die-off constant (Metcalf \& Eddy, 2003). Because of deviations from this law, such as tailing or shoulders caused by media interactions, disinfectant decay, and other factors, this law or equation has been modified by Hom to also consider the effect of time on the rate of disinfection (Hom, 1972). Another approach based on equations recommended by the Water Environment Federation (WEF, 1996) assumes a linear relationship between dosage-response and concentration after initial oxidant demand, for a given time. These approaches to disinfection modeling were applied to a series of dosage-response curves of ferrate acting upon the test organisms in a saline environment, to establish which model best predicted the action of ferrate on these organism. The literature review in Chapter 2 of this thesis delves further into the topic of disinfection modeling, as well as the subjects of ballast water, regrowth, and microbial iron metabolism. 
Many variables could affect disinfection on-board, such as $\mathrm{pH}$, salinity, initial bacterial concentration, temperature, and organic content. The first three of these variables were tested for their effect on ferrate disinfection, and the possibility of regrowth was also explored. Results of this testing and of the disinfection and disinfection modeling are presented in Chapter 3 , as a paper to be submitted to Water Environment Research. A dose of $5 \mathrm{mg} / \mathrm{l}$ resulted in complete disinfection of all organisms tested, and smaller dosages were also very effective. Tailing was consistently observed, and the Hom's model had the highest correlation coefficients.

This leads to the conclusion, discussed further in Chapter 4, that disinfection with ferrate can meet international standards, that the Hom's model can be used to estimate log removals under conditions similar to experimental conditions, and that further testing is warranted. Practical considerations are also discussed, and lead to some of the recommendations for future study outlined in Chapter 5. 


\section{CHAPTER 2: LITERATURE REVIEW}

\subsection{Ballast Water}

Ballast water provides stability to ocean-going vessels, and its uptake and discharge allows ships to compensate for cargo loads. Because ballast water is a sample of one ecosystem being transplanted into another, it represents a great potential for biological invasion. American waters receive more than 79 million tonnes of foreign ballast water per year (Carlton et al, 1995), and the number of species carried in these waters is vast. All major marine trophic groups were found in ballast water from Japanese cargo ships in an Oregonian port, such that ballast water acts as a phyletically and ecologically nonselective transport vector (Carlton and Geller, 1993). Many recent biological invasions have been attributed to ballast water release, the most famous of which is Dreissena polymorpha, the zebra mussel, which was most likely introduced via release of larvae contained in ship ballast water into the Great Lakes in the late 1980s (Hebert et al., 1989). The zebra mussel continues to expand its range, and its tendency to form dense mats has lead to pipe fouling at power plants and other facilities (Kovalak et al, 1993).

Bacteria are also among the aquatic nuisance species (ANS) introduced by ballast water discharge. One study found Vibrio cholerae 01 in ballast water from five of 19 cargo ships sampled in Alabama and Mississippi (McCarthy and Khambaty, 1994), causing the Food and Drug Administration and US Coast Guard to recommend that ship crews exchange their ballast water in mid-ocean, prior to entry into US ports. Viable counts of the $V$. cholerae were on the order of $10^{6} / \mathrm{ml}$, in salinities ranging from 12 to $32 \mathrm{ppt}$, again 
emphasizing the potential environmental impacts of ballast water. However, open-ocean exchange proved inadequate, and even fresh-water flushing leaves many viable organisms (Hulsmann and Galil, 2001). Because of the growing urgency of this problem, voluntary international guidelines for ballast water management have been established by the Maritime Environment Protection Committee (MEPC) of the International Maritime Organization (IMO) (Raaymakers, 2001), and performance specifications have been set for the successful testing and approval of ballast water management systems.

\subsection{Ferrate as a Disinfectant}

Ferrate $\left(\mathrm{FeO}_{4}^{-}\right)$is iron with a valence of +6 , which confers upon it a strong tendency to accept electrons, to attain its preferred valence of +2 or +3 . Therefore, it acts as an oxidant, like many disinfectants, with a reduction potential of $+2.20 \mathrm{~V}$ in acidic solution and $+0.72 \mathrm{~V}$ in alkaline solution (Wood, 1957). This reduction potential makes it a more powerful oxidant in acid than hypochlorite, ozone, hydrogen peroxide, or permanganate (Lee et al, 2004). By oxidizing molecules, it inactivates enzymes, resulting in cell death (Metcalf \& Eddy, 2003). Because of its steric resemblance to the phosphate anion, ferrate binds to enzyme phosphoryl groups and therefore site-specifically inactivates phosphatases, dehydrogenases, phosphorylase $b$, phosphoglucomutase, and other proteins with this functional group. It also specifically oxidizes amino acid residues on muscle phosphorylase, pancreatic ribonuclease, triose phosphate isomerase, and E. coli DNA polymerase-I (Basu et al, 1987). Because the byproduct of ferrate is $\mathrm{Fe}^{+3}$, it can also be 
used as a coagulant (Jiang et al, 2002), and for other uses, but its cost of production has hindered its usage.

Disinfection commonly has two goals: the immediate destruction or inactivation of pathogens and persistent inactivation of pathogens through residual action (Xie, 2004). An ideal disinfectant should be toxic to microorganisms, yet non-toxic to higher forms of life. Treatment of ballast water, and other applications to prevent the spread of invasive species, has slightly different goals, since the water is typically treated and then released into the local environment. Because the local species are quite similar to the alien species, the disinfectant should not persist in the environment, to avoid harming the local biota. Also, some higher organisms, such as crustaceans, are considered invasive, so an ideal disinfectant for ballast water would have a broader spectrum of action. Many oxidants have the disadvantage of producing disinfection byproducts (DBPs). For example, trihalomethanes (THMs) are a common DBP of chlorination, and their concentration in drinking water is regulated because of health concerns (Metcalf \& Eddy, 2003), although the validity of those concerns is debatable (White, 1999). Ferrate has the advantage that its breakdown product is some form of iron, which is non-toxic to humans except in very large doses. However, other environmental impacts must be considered. For example, to avoid bacterial, algal, and phytoplankton blooms, release of ferrate-treated water should be avoided in the few oceanic areas in which iron appears to be the limiting nutrient for bacterial growth: equatorial Pacific and other high-nutrient, low-chlorophyll (HNLC) areas, upwelling regions, the Southern Ocean, and the sub-Arctic Pacific (Kirchman, 2000). Moreover, even if the breakdown product of the oxidant is not in itself toxic, they can react with constituents in the water to produce environmentally harmful products. THMs, for 
example, are formed by the reaction of natural organic matter with chlorine or other oxidants (Metcalf \& Eddy, 2003). The presence of natural organic matter also reduces the effectiveness of oxidants. In the case of chlorination, this produces a stepwise phenomena referred to as breakpoint chlorination chemistry, in which the chlorine first reacts with readily oxidizable organic and inorganic material, then with ammonia to form chloramines, and then with less readily oxidizable molecules, including, presumably, the target species, producing a free chlorine residual when oxidizable matter is consumed (Matheickal et al, 2004). Thus, one would expect the action of ferrate to vary with respect to organic content, in terms of both effectiveness and possible DBP formation.

Three general methods of synthesizing ferrate have been used: wet oxidation, dry oxidation, and electrolysis (Lee et al, 2004). Electrolysis involves the anodization of a pure iron electrode in concentrated alkaline solution. The reaction at the cathode is:

$$
\mathrm{Fe}+8 \mathrm{OH}^{-} \rightarrow \mathrm{FeO}_{4}{ }^{-2}+4 \mathrm{H}_{2} \mathrm{O}+6 \mathrm{e}^{-}
$$

In dry oxidation, iron oxides are treated with oxidants at high temperature and pressure to generate ferrate salts, as in the following reaction:

$$
\mathrm{Fe}_{2} \mathrm{O}_{3}+3 \mathrm{Na}_{2} \mathrm{O}_{2} \rightarrow 2 \mathrm{Na}_{2} \mathrm{FeO}_{4}+\mathrm{Na}_{2} \mathrm{O}
$$

Dry oxidation has the advantage of a one-step, high-yield process (Perfiliev and Sharma, 2004), and shows potential as a green technology to recycle iron oxide wastes from steel manufacturing processes. Wet oxidation shows good potential for small-scale ferrate production, but the requirement for relatively pure chemicals leads to relatively high costs (Lee et al, 2004). Typically, ferric ion is oxidized to ferrate by concentrated 
hypochlorite in strong basic solution, after which it is precipitated as potassium ferrate by the addition of excess potassium hydroxide, according to the following reactions:

$$
\begin{aligned}
& 2 \mathrm{Fe}(\mathrm{OH})_{3}+3 \mathrm{NaClO}+4 \mathrm{NaOH} \rightarrow 2 \mathrm{Na}_{2} \mathrm{FeO}_{4}+3 \mathrm{NaCl}+5 \mathrm{H}_{2} \mathrm{O} \\
& 2 \mathrm{Na}_{2} \mathrm{FeO}_{4}+2 \mathrm{KOH} \rightarrow \mathrm{K}_{2} \mathrm{FeO}_{4} \downarrow+2 \mathrm{NaOH}
\end{aligned}
$$

Ferrate Treatment Technologies has developed a novel, patented, wet oxidation method of ferrate synthesis, using relatively inexpensive chemicals, that can be conducted with equipment onboard a vessel, for on-site ballast treatment, using the following reaction:

$$
\mathrm{H}_{2} \mathrm{O}+2 \mathrm{NaOH}+3 \mathrm{CaOCl}+\mathrm{FeCl}_{3} \rightarrow \mathrm{Na}_{2} \mathrm{FeO}_{4}+3 \mathrm{CaCl}_{2}+2 \mathrm{H}_{2} \mathrm{O}
$$

Ferrate salts decompose to non-toxic forms of iron in aqueous solution, such as ferric hydroxide, which precipitates according to the following equation (Jiang and Lloyd, 2002):

$$
4 \mathrm{Na}_{2} \mathrm{FeO}_{4}+10 \mathrm{H}_{2} \mathrm{O} \rightarrow 4 \mathrm{Fe}(\mathrm{OH})_{3} \downarrow+8 \mathrm{NaOH}+3 \mathrm{O}_{2} \uparrow
$$

Ferrate can also decompose to ferric oxyhydroxides, according to the following equation (Schink and Waite, 1980):

$$
2 \mathrm{FeO}_{4}^{-2}+3 \mathrm{H}_{2} \mathrm{O} \rightarrow 2 \mathrm{FeO}(\mathrm{OH})+1.5 \mathrm{O}_{2}+4 \mathrm{OH}^{-}
$$

The rate of decomposition depends upon many factors, including $\mathrm{pH}$, temperature, and initial ferrate concentration. According to a Pourbaix diagram, ferrate is most stable in an alkaline, highly aerobic environment. It will convert to aqueous ferric and ferrous iron in acidic, aerobic environments, and to non-aqueous $\mathrm{Fe}(\mathrm{OH})_{3}$ and $\mathrm{Fe}(\mathrm{OH})_{2}$ precipitates in 
alkaline, aerobic-to-somewhat anoxic conditions, and to solid $\mathrm{Fe}$ in highly anoxic (i.e. reducing or low oxidation-reduction potential) conditions, across the entire $\mathrm{pH}$ range. More dilute solutions result in a decreased driving force towards precipitation (Western Oregon Univ., 2006). Seawater is typically slightly alkaline, so depending on the oxygen levels, decomposing ferrate would be expected to precipitate as a hydroxide or as solid Fe, as long as the $\mathrm{pH}$ does not become acidic. Precipitation of ferrate might be a useful method to remove it from treated ballast water, prior to discharge, in order to meet effluent iron standards. These vary widely by state, country, and water classification. Within Florida waters, the maximum iron standard ranges from 0.3-1.0 mg/l (Florida Department of Environmental Protection, 2006).

\subsection{Disinfection Modeling}

The effectiveness of ferrate must be compared with that of free chlorine and chloramines, as well as other disinfectants, using similar techniques and models. The CT approach, used commonly in drinking water regulations (American Water Works Assn., 1999), looks at combinations of concentrations and contact times. It assumes a linear relationship between contact time and disinfection. This is rarely observed, however. Often, there are tailing and shoulder or lag effects, resulting from disinfectant, environmental, and bacterial characteristics, and numerous modelers have sought to explain these relationships, and to predict disinfection rates from them. The Chick-Watson law relates the survival rate of the target organism to the concentration of disinfectant and a dieoff constant (Metcalf and Eddy, 2003). It is expressed as: 


$$
\mathrm{dN}_{\mathrm{t}} / \mathrm{dt}=-\mathrm{k}^{\prime} \mathrm{C}^{\mathrm{n}} \mathrm{N}_{\mathrm{t}}
$$

where $\mathrm{N}_{\mathrm{t}}$ is the number of organisms at time $\mathrm{t}, \mathrm{k}$ ' is the die-off constant, $\mathrm{C}$ is the concentration of disinfectant, and $\mathrm{n}$ is a coefficient of dilution which determines the relative importance of disinfectant concentration. The integrated form of this equation is:

$$
\ln \left(\mathrm{N}_{\mathrm{t}} / \mathrm{N}_{0}\right)=-\mathrm{k}^{\prime} \mathrm{C}^{\mathrm{n}} \mathrm{t}
$$

where $\mathrm{N}_{0}$ is the starting bacterial concentration. When $\mathrm{n}$ is greater than 1 , concentration is more important than time, and vice versa. Deviations from this law, such as tailing or shoulders caused by media interactions, disinfectant decay, and other factors, result in a non-linear graph of time versus survival $\left(\mathrm{N}_{\mathrm{t}} / \mathrm{N}_{0}\right)$. A log-log plot can still result in a linear graph for these deviations, provided $\mathrm{C}^{\mathrm{n}} \mathrm{t}$ is a constant (American Water Works Assn., 1999). In order to better describe deviations from Chick-Watson behavior, Equation 7 was modified by Hom to also consider the non-linear effect of time (Hom, 1972). The integrated form of Hom's equation is:

$$
\ln \left(\mathrm{N}_{\mathrm{t}} / \mathrm{N}_{0}\right)=-\mathrm{k}^{\prime} \mathrm{C}^{\mathrm{n}} \mathrm{t}^{\mathrm{m}}
$$

where $\mathrm{m}$ is a coefficient of importance for time. The rate of inactivation decreases with time when $\mathrm{m}$ is less than 1 . Adding the $\mathrm{m}$ coefficient permits further characterization of the effect of time on disinfection efficiency, but might also lead to over-parameterization.

The Hom's equation has been further modified to consider disinfectant decay/demand (Haas and Joffe, 1994). If the decay/demand is first order, then: 


$$
\mathrm{C}_{\mathrm{t}}=\mathrm{C}_{0} \mathrm{e}^{\left(-\mathrm{k}^{*} \mathrm{t}\right)}
$$

where $\mathrm{C}_{0}$ is initial disinfectant concentration, $\mathrm{C}_{\mathrm{t}}$ is the concentration at time $\mathrm{t}$, and $\mathrm{k}^{*}$ is a rate constant. First-order decay appears to be a close approximation for chlorine and ozone decomposition. Applying this to the Hom's equation results in the following:

$$
\ln \left(\mathrm{N}_{\mathrm{t}} / \mathrm{N}_{0}\right)=-\mathrm{k}^{\prime} \mathrm{C}_{0}{ }^{\mathrm{n}} \mathrm{t}^{\mathrm{m}} \eta
$$

where $\eta$ is an efficiency factor to correct for disinfectant loss. The solution requires the incomplete $\gamma$ function and is therefore difficult to solve by standard computer packages. A simplifying assumption that disinfectant demand is minor results in the following approximation:

$$
\eta=\left[\left\{1-\mathrm{e}^{(-\psi / \mathrm{m})}\right\} /(\psi / \mathrm{m})\right]^{\mathrm{m}}
$$

where $\psi=\mathrm{n} * \mathrm{k} * \mathrm{t}$. This can then be substituted into Eqtn. 12 .

A general differential rate law of disinfection states that the rate of inactivation, $\mathrm{dN} / \mathrm{dt}$, relates to its components as:

$$
\mathrm{dN} / \mathrm{dt}=-\mathrm{kmN}^{\mathrm{x}} \mathrm{C}^{\mathrm{n}} \mathrm{t}^{\mathrm{m}-1}
$$

where $\mathrm{k}$ is an experimental reaction rate constant, $\mathrm{x}$ is an empirical constant, and other variables are as previously defined (Gyurek and Finch, 1998). This equation reduces to the Chick-Watson equation when $\mathrm{m}=1$ and $\mathrm{x}=1$, and to the Hom's equation when $\mathrm{x}=1$.

Furthermore, if first-order rate kinetics are assumed, then: 


$$
\mathrm{dN} / \mathrm{dt}=-\mathrm{kmN}^{\mathrm{x}} \mathrm{C}_{0} \mathrm{e}^{\mathrm{n}} \mathrm{k}^{\mathrm{k} t} \mathrm{t}^{\mathrm{m}-1}
$$

In this equation, $\mathrm{k}^{\prime}$ is the rate of first-order disinfectant decay. Integrating this, with $\mathrm{m}=1$, results in the Rational model, calculated by Haas et al (1994) as:

$$
\log \left(\mathrm{N} / \mathrm{N}_{0}\right)=-\log \left[1+(\mathrm{x}-1)^{*}(\mathrm{k} /(\mathrm{k} n)) *\left(\mathrm{C}_{0}{ }^{\mathrm{n}}-\mathrm{C}_{\mathrm{f}}{ }^{\mathrm{n}}\right) * \mathrm{~N}_{0}{ }^{\mathrm{x}-1}\right] /(\mathrm{x}-1)
$$

Yet another variation on the Chick-Watson model includes a lag phase, in which limited inactivation occurs, followed by a first order (i.e. $\mathrm{n}=1$ ) Chick-Watson equation (Rennecker et al, 2001). The lag phase accounts for observed shoulder effects in inactivation of protozoan cysts. This is similar to the Collins-Selleck model, which also has a biphasic model:

$$
\begin{aligned}
& \text { For } \mathrm{C}_{\mathrm{t}}<=\mathrm{T}, \mathrm{N} / \mathrm{N}_{0}=1 \\
& \text { For } \mathrm{C}_{\mathrm{t}}>=\mathrm{T}, \mathrm{N} / \mathrm{N}_{0}=\left(\mathrm{T} /\left(\mathrm{C}_{\mathrm{t}}\right)^{\mathrm{n}}\right.
\end{aligned}
$$

$\mathrm{T}$ and $\mathrm{n}$ are experimental constants that can be calculated from a linear adjustment of the logarithmic form of Equation 17 (Qualls and Johnson, 1985). This model adjusts for an initial reduction of disinfectant upon contact with the water or medium. Hassen et al (2000) found it necessary to add another experimental constant, m, such that Equation 17 becomes:

$$
\text { For } \mathrm{C}_{\mathrm{t}}>=\mathrm{T}, \mathrm{N} / \mathrm{N}_{0}=\left(\mathrm{T} /\left(\mathrm{C}^{\mathrm{m}} \mathrm{t}\right)^{\mathrm{n}}\right.
$$

in order for this model to adequately describe inactivation of indicator bacteria (fecal coliforms and fecal streptococci) by chlorine. 
The original Selleck model derived from an empirical model to explain the rate of inactivation of coliform bacteria by chlorine. Its linear form is:

$$
\log \left(\mathrm{N} / \mathrm{N}_{0}\right)=-\mathrm{n} \log \left[1+\left(\mathrm{C}_{0} / \mathrm{kk}^{\prime}\right)^{*}\left(1-\mathrm{e}-{ }^{\mathrm{k}^{\mathrm{t}} \mathrm{t}}\right)\right]
$$

Again, $\mathrm{n}$ and $\mathrm{k}$ are determined experimentally (Selleck et al, 1978), and it is used primarily to describe initial shoulder effects, followed by a reduction in disinfection (Gyurek and Finch, 1998).

Another model for microbial inactivation by chemical disinfection is analogous to the model for microbial growth, and is therefore referred to as the Monod model (Haas, 1981). It states that:

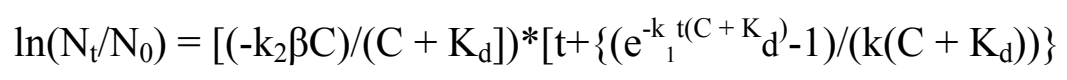

In this equation, $\beta$ is the number of disinfectant-binding sites on the organism, $\mathrm{k}, \mathrm{k}_{1}$, and $\mathrm{k}_{2}$ are constants, and $\mathrm{C}$ is the liquid concentration of disinfectant, which is distinguished from the concentration of disinfectant at the microbial surface. Also, since it is analogous to Michaelis-Menten enzyme kinetics, $K_{d}$ is a Michaelis constant, i.e. $K_{d}=k_{-1} / k_{1}$. A concentration-dependent lag phase is implicit in this model, and the rate of disinfection is defined as the slope of the linear portion of a plot of $\ln \left(\mathrm{N}_{\mathrm{t}} / \mathrm{N}_{0}\right)$ vs. t.

An equation recommended by the Water Environment Federation Wastewater Disinfection Manual of Practice (WEF, 1996) has been adapted to describe inactivation of a dinoflagellate alga in ballast water by ozone (Oemcke and van Leeuwen, 2005), in the form: 


$$
-\log \left(\mathrm{N} / \mathrm{N}_{0}\right)=\mathrm{b}(\log \mathrm{C})+\mathrm{d}
$$

where $\mathrm{C}$ is the oxidant concentration after initial demand has been met, $\mathrm{b}$ and $\mathrm{d}$ are experimental regression coefficients, and other terms are as described. A steeper slope (i.e. higher $\mathrm{b}$ ) indicates a higher kill achieved with relatively low doses, and a higher x-intercept indicates a relatively high initial oxidant demand. This is not a rate equation, but a statement of survival as a function of dose, so the coefficients must be determined for each experimental contact time. This equation is referred to as the "oxidant demand" model.

Both the Chick-Watson and Hom's equations assume that the concentration of disinfectant is constant for the test period or for a given contact time. This is not necessarily valid for some disinfectants, such as free chlorine(Haas, 1979). Assuming that disinfectant concentration follows first-order decay requires the incomplete $\gamma$ function for an exact solution of the Hom's model (Haas and Joffe, 1994). However, many studies have found good correlation coefficients using Chick-Watson or Hom's models for disinfection of various bacteria by free chlorine, implying that the assumptions of these models are valid over the contact times studied (Haas and Karra, 1984), probably because coefficients for time adjust for the loss of disinfectant.

\subsection{Mechanisms for Disinfection Kinetics Deviations}

As mentioned, a perfectly linear relationship between contact time and disinfection levels is rarely observed, and advances in disinfection modeling have addressed tailing and shoulder effects. A shoulder effect refers to a lag phase in the survival vs. time graph, and 
often occurs in organisms that form clumps, such as Naegleria gruberii (AWWA, 1999). This is because a colony or plaque-forming unit is not inactivated until all of its member cells are inactivated, causing an initial lag phase. Clumping can also cause tailing, as can several other mechanisms, including:

- Characteristics of the bacterial population, including resistant subpopulations, clumping, or hardening.

- Characteristics of the media, such as shielding by large particles.

- Nature of the disinfectant, such as decay.

Obviously, different classes and species of microorganisms have differing susceptibilities to various disinfectants and disinfection processes. The United States EPA has identified Mycobacterium avium as the most disinfectant-resistant waterborne bacteria on its Contaminate Candidate List (Gerba et al, 2003). However, other bacteria are capable of developing resistant subpopulations. For example, a chlorine-resistant subpopulation of fecal coliforms has been identified in the oxidation towers of a Virginia wastewater treatment plant that was experiencing erratic disinfection rates (Scully et al, 1999). The natural variability of a bacterial population favors the development of a resistant subpopulation under adverse conditions.

Hardening is conversion to resistant forms during disinfection. It was initially observed in poliovirus in response to formaldehyde inactivation during preparation of the Salk vaccine (Nathanson and Langmuir, 1963). Bacteria and other microorganisms possess many mechanisms for responding to adverse environmental, including, among some 
bacterial species, the formation of spores, a dehydrated life-stage that is resistant to chemical and UV disinfection, as well as $\mathrm{pH}$, temperature, and water moisture conditions.

Shielding can be a major problem in wastewater, which of course has a great deal of particulate matter, and one study found that a critical particle size was necessary to shield coliform bacteria from UV disinfection in secondary wastewater (Emerick et al, 2000). Shielding is a potential product in any water that contains particles, which includes almost all salt and fresh waters.

Obviously, the problem of disinfectant decay in drinking water has been addressed by the inclusion of a chlorine, or other disinfectant, residual. However, chemicals tend to interact with other chemicals, with organisms, and with the environment, so decay or displacement has been addressed by numerous models. Analysis of a drinking water system using a network water quality model that included disinfectant kinetics and decay lead to a prediction of unacceptable risks from pathogenic bacteria intrusion, even with a detectable chloramine residual (Propato and Uber, 2004). Sohn et al (2004) compared and improved various models of disinfectant decay, and found good predictions for chlorine decay by both empirical power function models and empirical kinetic models. These models are generally very complex. Although the Hom's model assumes constant disinfectant concentration, it can also be used with a geometric mean residual $\left(\mathrm{C}_{\mathrm{ave}}\right)$, if the initial and final disinfectant concentrations $\left(\mathrm{C}_{0}\right.$ and $\left.\mathrm{C}_{\mathrm{f}}\right)$ are known, resulting in the equation (Finch et al, 1993):

$$
\log \left(\mathrm{N}_{\mathrm{t}} / \mathrm{N}_{0}\right)=-\mathrm{k}\left(\mathrm{C}_{\mathrm{ave}}\right)^{\mathrm{n}} \mathrm{t}^{\mathrm{m}}
$$


Likewise, different models have been used to address different mechanisms of deviation from ideal disinfection behavior. Equation 12, for example, has been used to address the general problem of tailing, but it is difficult to use and highly empirical (AWWA, 1999). If disinfectant concentration is constant, it reduces to Equation 8, which is easier to use. Shoulder effects have been described by a number of models, including a series event, a multitarget, or a diffusional model. Models also try to account for other phenomena that affect disinfection rates by influencing natural die-off rates, such as temperature, salinity, and sunlight. These generally affect the rate constant, $\mathrm{k}$ or k'. The Arrhenius equation, for example, predicts a change in the die-off rate constant according to the relationship:

$$
\mathrm{k}^{\prime}{ }_{\mathrm{T}}=\mathrm{k}^{\prime}{ }_{20} \mathrm{~B}^{(\mathrm{T}-20)}
$$

where $\mathrm{T}$ is the temperature of interest in Celsius, $\mathrm{k}_{20}{ }_{20}$ is the rate constant at $20^{\circ} \mathrm{C}$, and $\mathrm{B}$ is an empirical constant related to activation energy and the universal gas content (WEF, 1996), represented as $\theta$ in other texts. Equation 23 is only valid for temperatures that are not lethal to bacteria.

\subsection{Regrowth}

Regrowth measures the ability of disinfectant-damaged microbes to recover through repair mechanisms and reproduce, which is a major issue for drinking water, since even small numbers of pathogens can cause significant harm to the public. It is most often a problem following UV irradiation (WEF, 1996). It is distinguished from aftergrowth, 
which is the growth of native microbes within the water distribution system (Escobar et al, 2001). Regrowth is dependent upon the amount of nutrients and organic matter in the medium, which is referred to as bacterial regrowth potential (BRP). Therefore, it correlates with dissolved organic content (DOC) and total dissolved nitrogen (Bolster et al, 2005), total organic content (TOC) (Rizzo, et al, 2004), and assimilable organic content (AOC) (Escobar et al, 2001), a readily usable form of biodegradable organic carbon. Furthermore, the source of the organic matter affects BRP. Freshly derived terrestrial dissolved organic matter (DOM), for example, correlated with a higher BRP than did reservoir water DOM (Page et al, 2002). The authors postulated that this is due to microbial pre-degradation of the reservoir-derived DOM, such that it is a less desirable substrate.

Corrosion products from pipes and other materials can indirectly increase regrowth rates by creating an oxidant demand and therefore reducing the level of disinfection. Likewise, nutrients such as humic acid can also exert an oxidant demand, and therefore increase re-growth rates by serving as food for bacteria and by lowering disinfectant efficiency. Thus, disinfectant levels, corrosion products, and nutrient levels appear to exert a complex interaction upon the growth of Mycobacterium avium (Norton et al, 2004). A model to predict the regrowth and aftergrowth potential of drinking water, based on its nutrient potential, has been developed by Jegatheesan et al (2004). It incorporates Monodtype bacterial growth, bacterial death and lysis, and measurements of BDOC fractions to predict the growth potential of indigenous bacteria based on nutritional status of the water. Regrowth can affect the kinetics of disinfection, but generally has a minor impact (WEF, 1996). 


\subsection{Microbial Utilization of Iron}

Iron metabolism in bacteria will affect their susceptibility to ferrate, as well as their use of its reduced forms. Iron is required in a myriad of metabolic processes, by both eukaryotes and prokaryotes. It is, for example, a cofactor for many enzymes, and a major role of iron in mammals and other eukaryotes is as a component of heme, used to transport oxygen. In an aerobic, $\mathrm{pH}-$ neutral environment, ferric iron $\left(\mathrm{Fe}^{+3}\right)$ has a concentration of less than $10^{-18} \mathrm{M}$, because iron hydroxide, $\mathrm{Fe}\left(\mathrm{OH}_{3}\right)$, is insoluble under these conditions (Raymond and Dertz, 2004). Hence, organisms have evolved mechanisms for recognizing, transporting, and storing iron, which results in an even lower concentration of free iron within their circulatory systems. Pathogenic bacteria compete for iron binding with their host by two main strategies. One is by essentially stealing iron from host proteins by binding heme to outer membrane receptors and transporting it into the cell by ABC (ATPbinding cassette) permeases. This strategy can involve hemophores, which bind heme initially and then bind to specific outer membrane receptors (Debarbieux and Wandersman, 2004). The second strategy is the production of siderophores, which are chelating agents that specifically and strongly bind iron and deliver it to bacterial cell surface receptors, which transport it by permeases into the cell. Bacteria exposed to blood produce siderophores, emphasizing the importance of competition with host proteins for iron, and the production of siderophores by bacteria is one aspect of virulence, because the loss of iron to the pathogen inhibits or hinders the host's defenses. There are three broad groups of siderophores, classified by the chelating group: catecholates, hydroxamates, and hydroxycarboxylates. Catecholates, for example, contain catechol, which has two 
hydroxyls attached to an aromatic ring; the oxygen atoms bind iron. In gram-positive bacteria, iron-siderophore complexes are recognized by binding proteins anchored to the inner membrane, and transported by $\mathrm{ABC}$ permeases into the cell (Raymond and Dertz, 2004). Gram-negative bacteria, on the other hand, possess high-affinity outer membrane receptors that capture iron-siderophore complex and translocate them into the periplasmic space through the Ton complex, which is coupled to the proton-motive force in the cytoplasmic membrane, for eventual transfer into the cell by periplasmic-binding proteins and ATP-dependent membrane transporters (Cohen, 2004). Many bacteria produce more than one type of siderophore. Escherichia coli, for example, produces enterobactin, a catecholate siderophore with three catechol groups, giving it six coordinating atoms per molecule, and aerobactin, a carboxylate-hydroxymate mixed siderophore. For a siderophore to be effective, the iron-siderophore complex must be more stable than the iron hydroxide, and it must have comparable or greater affinity for iron than the host transport/storage proteins. For a siderophore to contribute to virulence, its affinity must be greater than that of the host proteins (Raymond and Dertz, 2004).

Some pathogenic bacteria can be found in the marine environment. For example, $E$. coli, a well-characterized member of the enteric bacteria and a common cause of gastroenteritis (Brock et al, 1994), is almost ubiquitous. Enteric bacteria are a group of gram-negative, oxidase-negative, nonsporulating, facultatively aerobic, sugar-fermenting bacilli. The Vibrio genus is comprised of salt-tolerant species, growing naturally in sea water, that produce a variety of infections, including gastroenteritis, wound and ear infections, and sepsis. V. cholerae, the causative agent of cholera, is a small, gramnegative sucrose-fermenting. Serotype O1 is associated with epidemic disease. Species of 
Vibrio have two chromosomes, unlike most other bacteria, and genes for multiple iron transport systems are located on both chromosomes. Plasmids can also supply siderophorecoding genes to Vibrio species, which can also contribute to virulence. V. cholerae uses a catechol siderophore-vibriobactin — as well as a heme receptor and other iron transport systems. Vibriobactin production is highest in environmental isolates, suggesting that this siderophore is more important than the other iron transport systems in the environment. Since heme is a common constituent of vertebrate blood, but not of marine environments, one would expect heme receptors to gain importance in the vertebrate host. V. vulnificus is an opportunistic marine pathogen that causes hemorrhagic septicemia in humans and marine animals, with a high associated mortality rate. It uses a catecholate siderophore very similar to vibriobactin — vulnibactin —and a hydroxamate siderophore. Vibrio are not particular about where they get their iron; they possess outer membrane receptors that recognize siderophores from other bacteria, including enterobactin from Enterobacteriaceae (DiLorenzo et al, 2004).

In marine environments, iron enters the water by solubilization of the earth's crust, which contains abundant iron (Kirchman, 2000), and by atmospheric deposition of Aeolian dust into the sea (Duce and Tindale, 1991). However, the insolubility of iron oxides limits its availability, and its use by phytoplankton reduces it still more in the marine surface layer. Heterotrophic bacteria account for perhaps $40 \%$ of total iron use in the ocean, and iron appears to be the limiting nutrient for bacterial growth in a few oceanic areas: equatorial Pacific and other low-chlorophyll, high-nutrient (HNLC) areas, upwelling regions, the Southern Ocean (Kirchman, 2000), and the sub-Arctic Pacific (Falkowski, 1995). The enzymes involved in nitrate assimilation and $\mathrm{N}_{2}$ fixation use iron as a 
coenzyme, and iron shortage seems to constrain the rates of these processes (Duce and Tindale, 1991). Cyanobacteria — a group of bacteria capable of photosynthesis and also called the blue-green algae (Lehninger, 1982)—have been the best-studied group for response to iron limitation. Changes include an increase in glycogen reserves, reduction in the numbers of some proteins, such as thylakoids, which support photosynthetic processes, and production of novel proteins, including siderophores (Mann, 1995). Ferredoxin, an iron-containing enzyme which carries electrons from chlorophyll to various electron donors (Falkoski, 1995), is replaced by the flavin mononucleotide (FMN)-containing flavodoxin (Lehninger, 1982). Thus, bacteria have strategies to respond to iron limitations, but it does appear to limit microbial growth in some marine environments.

After transport into the microbial cell, ferric iron is reduced to facilitate its removal from the chelating claws of the siderophore, and siderophore-transported iron has been found in the intracellular $\mathrm{Fe}^{+2}$ pool within 30 minutes of transport. This is apparently accomplished by siderophore-iron reductases. Intracellular storage of iron is complicated by its chemical properties, which favor the formation of toxic free radicals and insoluble ferric-hydroxide polymers. Mammalian cells therefore store iron as haemosiderin and ferritin, protein shells surrounding an inorganic ferric oxyhydroxide core. Ferritin consists of an oligomeric protein of 24 similar or identical subunits that form a hollow protein shell. The core stores up to 4500 iron atoms as ferric hydroxyphosphate micelles, which are nontoxic and bioavailable. Likewise, bacteria store iron in bacterioferritins, which are very similar to human ferritin, or in ferritin-like proteins. Ferritin is highly conserved across species (Crichton, 2001). 


\section{CHAPTER 3 - RESULTS AND DISCUSSION}

\section{Adapted from a Manuscript Submitted to Water Environment Research Journal}

\subsection{Introduction}

The introduction of aquatic nuisance species (ANS) and bacterial pathogens from discharge of ballast water by sea-faring vessels is an ongoing problem that threatens ecosystems and human health. Ballast water provides stability to ocean-going vessels, and its uptake and discharge allows ships to compensate for cargo loads. American waters receive more than 79 million tonnes of foreign ballast water per year (Carlton et al, 1995), and the number of species carried in these waters is vast. All major marine trophic groups were found in ballast water from Japanese cargo ships in an Oregonian port, such that ballast water acts "as a phyletically and ecologically nonselective transport vector" (Carlton and Geller, 1993). Many recent biological invasions have been attributed to ballast water release, the most famous of which is Dreissena polymorpha, the zebra mussel, which was most likely introduced via release of larvae contained in ship ballast water into the Great Lakes in the late 1980s (Hebert et al., 1989). Zebra mussels continue to expand their range, and their tendency to form dense mats has lead to pipe fouling at power plants and other facilities (Kovalak et al, 1993).

Bacteria are also among the aquatic nuisance species (ANS) introduced by ballast water discharge. One study found Vibrio cholerae 01 in ballast water from 5 of 19 cargo ships sampled in Alabama and Mississippi (McCarthy and Khambaty, 1994), causing the Food and Drug Administration and US Coast Guard to recommend that ship crews 
exchange their ballast water in mid-ocean, prior to entry into US ports. Viable counts of $V$. cholerae were on the order of $10^{6} / \mathrm{ml}$, in salinities ranging from 12 to $32 \mathrm{ppt}$, again emphasizing the potential environmental impacts of ballast water. However, open-ocean exchange proved inadequate, and even fresh-water flushing leaves many viable organisms in tanks (Hulsmann and Galil, 2001).

Because of the growing urgency of this problem, voluntary international guidelines for ballast water management have been established by the Maritime Environment Protection Committee (MEPC) of the International Maritime Organization (IMO) (Raaymakers, 2001), and performance specifications have been set for the successful testing and approval of ballast water management systems, including:

- The final concentration of Enterococci should be less than $1 \mathrm{CFU} / \mathrm{ml}$, - The final concentration of Escherichia coli should be less than $2.5 \mathrm{CFUs} / \mathrm{ml}$, and

- The final concentration of Vibrio cholerae should be less than $1 \mathrm{CFU} / 100 \mathrm{mls}$

An exact standard of reduction for coliforms has not been set, but the IMO specifications state that they should be measured in any proposed treatment method.

Disinfection of potable water commonly has two goals: the immediate destruction or inactivation of pathogens, and persistent inactivation of pathogens through residual action (Xie, 2004). An ideal disinfectant should be toxic to microorganisms, yet non-toxic to higher forms of life. Treatment of ballast water, and other applications to prevent the spread of invasive species, has slightly different goals than that of drinking water, since the water is typically treated, and then released into the local environment. Because the local species are quite similar to the aliens, the disinfectant should not persist in the environment, so that the local biota is not harmed. Also, some higher organisms, such as crustaceans, are considered invasive, so an ideal disinfectant for ballast water would have a broader 
spectrum of action. One agent that holds promise for ballast water disinfection is ferrate.

Ferrate is iron with a valence of +6 , which confers upon it a tendency to accept electrons, to attain its preferred valence of +2 or +3 . Therefore, it acts as an oxidant, like many disinfectants, with a reduction potential of $+2.20 \mathrm{~V}$ in acidic solution and $+0.72 \mathrm{~V}$ in alkaline solution (Wood, 1957). This reduction potential makes it a more powerful oxidant in acid than hypochlorite, ozone, hydrogen peroxide, or permanganate (Lee et al, 2004). By oxidizing other molecules, it inactivates enzymes, resulting in cell death (Metcalf \& Eddy, 2003). Because of its steric resemblance to phosphate anion, ferrate binds to enzyme phosphoryl groups and therefore site-specifically inactivates phosphatases, dehydrogenases, phosphorylase $b$, phosphoglucomutase, and other proteins with this functional group. It also specifically oxidizes amino acid residues on muscle phosphorylase, pancreatic ribonuclease, triose phosphate isomerase, and E. coli DNA polymerase-I (Basu et al, 1987). Ferrate can also be used as a coagulant (Jiang et al, 2002), and for other uses, but its cost of production has hindered its commercial usage.

Three general methods of synthesizing ferrate have been used: wet oxidation, dry oxidation, and electrolysis (Lee et al, 2004). Electrolysis involves the anodization of a pure iron electrode in concentrated alkaline solution. The reaction at the cathode is:

$$
\mathrm{Fe}+8 \mathrm{OH}^{-} \rightarrow \mathrm{FeO}_{4}^{-2}+4 \mathrm{H}_{2} \mathrm{O}+6 \mathrm{e}^{-}
$$

In dry oxidation, iron oxides are treated with oxidants at high temperature and pressure to generate ferrate salts, as in the following reaction:

$$
\mathrm{Fe}_{2} \mathrm{O}_{3}+3 \mathrm{Na}_{2} \mathrm{O}_{2} \rightarrow 2 \mathrm{Na}_{2} \mathrm{FeO}_{4}+\mathrm{Na}_{2} \mathrm{O}
$$


Dry oxidation has the advantage of a one-step process (Perfiliev and Sharma, 2004), and shows potential as a green technology to recycle iron oxide wastes from steel manufacturing processes. Typically, ferric ion is oxidized to ferrate by concentrated hypochlorite in strong basic solution, after which it is precipitated as potassium ferrate by the addition of excess potassium hydroxide. The resultant ferrate sludge is then washed and rinsed many times in alcohols and solvents to obtain a dry, powdered ferrate product according to the following reactions:

$$
\begin{aligned}
& 2 \mathrm{Fe}(\mathrm{OH})_{3}+3 \mathrm{NaClO}+4 \mathrm{NaOH} \rightarrow 2 \mathrm{Na}_{2} \mathrm{FeO}_{4}+3 \mathrm{NaCl}+5 \mathrm{H}_{2} \mathrm{O} \\
& 2 \mathrm{Na}_{2} \mathrm{FeO}_{4}+2 \mathrm{KOH} \rightarrow \mathrm{K}_{2} \mathrm{FeO}_{4} \downarrow+2 \mathrm{NaOH}
\end{aligned}
$$

Wet oxidation shows good potential for ferrate production, but the requirement for relatively pure chemicals has lead to high costs (Lee et al, 2004). A company located in Orlando, Florida, Ferrate Treatment Technologies, LLC ("FTT") has solved the high cost problem of prior wet oxidation ferrate synthesis methods, as well as possible issues of instability, packaging, handling, and transport. FTT developed and patented a novel, on site synthesis method, using relatively inexpensive chemicals, and has manufactured ferrate onboard a 67,000 ton container vessel for ballast treatment using both of the following reactions:

$$
\begin{aligned}
& \mathrm{H}_{2} \mathrm{O}+2 \mathrm{NaOH}+3 \mathrm{CaOCl}+\mathrm{FeCl}_{3} \rightarrow \mathrm{Na}_{2} \mathrm{FeO}_{4}+3 \mathrm{CaCl}_{2}+2 \mathrm{H}_{2} \mathrm{O} \\
& \mathrm{H}_{2} \mathrm{O}+2 \mathrm{NaOH}+3 \mathrm{NaOCl}+\mathrm{FeCl}_{3} \rightarrow \mathrm{Na}_{2} \mathrm{FeO}_{4}+3 \mathrm{NaCl}_{2}+2 \mathrm{H}_{2} \mathrm{O}
\end{aligned}
$$


Ferrate decomposes to non-toxic forms of iron in aqueous solution according to the following equation:

$$
2 \mathrm{FeO}_{4}^{-2}+3 \mathrm{H}_{2} \mathrm{O} \rightarrow 2 \mathrm{FeO}(\mathrm{OH})+1.5 \mathrm{O}_{2}+4 \mathrm{OH}^{-}
$$

The rate of decomposition depends upon many factors, including $\mathrm{pH}$, temperature, and initial ferrate concentration (Schink and Waite, 1980). According to a Pourbaix diagram, ferrate is most stable in an alkaline, highly aerobic environment. It will convert to aqueous ferric and ferrous iron in acidic, aerobic environments, and to non-aqueous $\mathrm{Fe}(\mathrm{OH})_{3}$ and $\mathrm{Fe}(\mathrm{OH})_{2}$ precipitates in alkaline, aerobic-to-somewhat anoxic conditions, and to solid Fe in highly anoxic (i.e. reducing or low oxidation-reduction potential) conditions, across the entire $\mathrm{pH}$ range. More dilute solutions result in a decreased driving force towards precipitation (Western Oregon Univ., 2006). Seawater is typically slightly alkaline, so depending on the oxygen levels, ferrate would be expected to precipitate out as a hydroxide or as solid Fe, as long as the $\mathrm{pH}$ does not become acidic. Precipitation of ferrate might be a useful method to remove it from treated ballast water, prior to discharge, in order to meet effluent iron standards. These vary widely by state, country, and water classification. Within Florida waters, the maximum iron standard ranges from $0.3-1.0 \mathrm{mg} / \mathrm{l}$ (Florida Department of Environmental Protection, 2006).

Many oxidants have the disadvantage of producing disinfection byproducts (DBPs). For example, trihalomethanes (THMs) are a common DBP of chlorination, and their concentration in drinking water is regulated because of health concerns (Metcalf \& Eddy, 2003), although the validity of those concerns is debatable (White, 1999). Ferrate has the advantage that its breakdown product is some form of iron, which is non-toxic to humans 
except in very large doses. Even if the breakdown products of the oxidant are not in themselves toxic, they can react with constituents in the water to produce environmentally harmful products. THMs, for example, are formed by the reaction of natural organic matter with chlorine or other oxidants (Metcalf \& Eddy, 2003). The presence of natural organic matter also reduces the effectiveness of oxidants. In the case of chlorination, this produces a stepwise phenomena referred to as "breakpoint chlorination chemistry", in which the chlorine first reacts with readily oxidizable organic and inorganic material, then with ammonia to form chloramines, and then with less readily oxidizable molecules, including, presumably, the target species, producing a chlorine residual after all oxidizable matter is consumed (Matheickal et al, 2004). Likewise, one would expect the action of ferrate to vary with respect to organic content, which creates an additional oxidant demand.

The effectiveness of ferrate must be compared with that of free chlorine and chloramines, as well as other disinfectants, using similar techniques and models. The CT approach, used commonly in drinking water regulations (American Water Works Assn., 1999), looks at combinations of concentrations and contact times. It assumes a linear relationship between contact time and degree of disinfection. This is rarely observed, however. Often, there are "tailing" and "shoulder" or "lag" effects, resulting from disinfectant, environmental, and bacterial characteristics, and numerous modelers have sought to explain these phenomena, and to predict disinfection rates from them. The Chick-Watson law relates the survival rate of the target organism to the concentration of disinfectant and a die-off constant (Metcalf and Eddy, 2003). It is expressed as:

$$
\mathrm{dN}_{\mathrm{t}} / \mathrm{dt}=-\mathrm{k}^{\prime} \mathrm{C}^{\mathrm{n}} \mathrm{N}_{\mathrm{t}}
$$


where $\mathrm{N}_{\mathrm{t}}$ is the number of organisms at time $t, \mathrm{k}^{\prime}$ is the die-off constant, $\mathrm{C}$ is the concentration of disinfectant, and $\mathrm{n}$ is a "coefficient of dilution" which determines the relative importance of disinfectant concentration. The integrated form of this equation is:

$$
\ln \left(\mathrm{N}_{\mathrm{t}} / \mathrm{N}_{0}\right)=-\mathrm{k}^{\prime} \mathrm{C}^{\mathrm{n}} \mathrm{t}
$$

where $\mathrm{N}_{0}$ is the starting bacterial concentration. When $\mathrm{n}$ is greater than 1 , concentration is more important than time. Deviations from this law, such as "tailing" or "shoulders" caused by media interactions, disinfectant decay, and other factors, result in a non-linear graph of time versus survival $\left(\mathrm{N}_{\mathrm{t}} / \mathrm{N}_{0}\right)$. A log-log plot can still result in a linear graph for these deviations, provided $\mathrm{C}^{\mathrm{n}} \mathrm{t}$ is a constant (American Water Works Assn., 1999). In order to better describe deviations from Chick-Watson behavior, Equation 2 was modified by Hom to also consider the effect of time (Hom, 1972). The integrated form of Hom's equation is:

$$
\ln \left(\mathrm{N}_{\mathrm{t}} / \mathrm{N}_{0}\right)=-\mathrm{k}^{\prime} \mathrm{C}^{\mathrm{n}} \mathrm{t}^{\mathrm{m}}
$$

where $\mathrm{m}$ is a coefficient of importance for time. The rate of inactivation decreases with time when $\mathrm{m}$ is less than 1. Adding the $\mathrm{m}$ coefficient permits further characterization of the effect of time on disinfection efficiency, but might also lead to over-parameterization.

A general differential rate law of disinfection states that the rate of inactivation, $\mathrm{dN} / \mathrm{dt}$, relates to its components as:

$$
\mathrm{dN} / \mathrm{dt}=-\mathrm{kmN}^{\mathrm{x}} \mathrm{C}^{\mathrm{n}} \mathrm{t}^{\mathrm{m}-1}
$$


where $\mathrm{k}$ is an experimental reaction rate constant and other variables are as defined (Gyurek and Finch, 1998). This equation reduces to the Chick-Watson equation when $\mathrm{m}=$ 1 and $\mathrm{x}=1$, and to the Hom's equation when $\mathrm{x}=1$. Both the Chick-Watson and Hom's equations assume that the concentration of disinfectant is constant for the test period or for a given contact time. This is not necessarily valid for some disinfectants, such as chlorine residual (Haas, 1979). Assuming that disinfectant concentration follows first-order decay requires the incomplete $\gamma$ function for an exact solution of the Hom's model (Haas and Joffe, 1994). However, many studies have found good correlation coefficients using Chick-Watson or Hom's models for disinfection of various bacteria by free chlorine, implying that the assumptions of these models are valid over the contact times studied (Haas and Karra, 1984).

An equation similar to one recommended by the Water Environment Federation Wastewater Disinfection Manual of Practice (WEF, 1996) has been used to describe inactivation of a dinoflagellate algae in ballast water (Oemcke and van Leeuwen, 2005), in the form:

$$
-\log \left(\mathrm{N} / \mathrm{N}_{0}\right)=\mathrm{b}(\log \mathrm{C})+\mathrm{d}
$$

where $\mathrm{C}$ is the oxidant concentration after initial demand has been met, $\mathrm{b}$ and $\mathrm{d}$ are experimental regression coefficients, and other terms are as described. A steeper slope (i.e. higher b) indicates a higher kill achieved with relatively low doses, and a higher $\mathrm{x}$-intercept indicates a relatively high initial oxidant demand. This is similar to the Chick-Watson model but does not consider time as a variable, so the coefficients must be determined for 
each experimental contact time. This equation is referred to as the "oxidant demand" model.

\subsection{Methods}

Heterotrophic and coliform bacteria were represented by Escherichia coli and Klebsiella pneumoniae (ATCC \#s 11303 and 13833, respectively). The Enterococcus group was represented by a mixed culture of Enterococcus faecium and E. faecilis (ATCC \#s 19434 and 19433, respectively). Vibrio cholerae was grown from ATCC \#51352 stock. Instant Ocean (IO, Aquarium Systems, Mentor, $\mathrm{OH}$ ) was added to de-ionized water to produce salt water at 36 ppt per the manufacturer's instructions. All bacteria were cultured under sterile conditions at room temperature $\left(22^{\circ} \mathrm{C}\right)$, with shaking at $25 \mathrm{rpm}$, in a 5:1 mixture of IO:nutrient broth ( $8 \mathrm{~g} / 1)$, for 3-4 days. At time of testing, the bacterial cell suspension was centrifuged for 10 minutes and resuspended in 36 ppt IO (unless otherwise indicated), under sterile conditions. Bacteria were washed twice more in this manner, resuspended in $36 \mathrm{ppt}$ IO, and quantified. E. faecium, E. faecilis, Escherichia coli, and K. pneumoniae were quantified by the IDEXX Quanti-Tray (IDEXX Laboratories, Inc., Westbrook, ME) enumeration procedure. $V$. cholerae was quantified by plate culture using nutrient agar (Difco brand, Becton Dickinson \& Co., Franklin Lakes, NJ). The suspension of bacteria was subdivided into a number of flasks or 50-ml centrifuge tubes, ferrate was added at a range of dosages with stirring or shaking, and bacterial enumeration was performed again at a number of time intervals for each dosage. At sampling time, an appropriate amount of liquid from each vial was transferred to a 100-ml Coliform Test Vial, with the sodium thiosulfate pellet 
already in solution, to stop the oxidation reaction immediately, in a final volume of $100 \mathrm{mls}$. Colilert-18 substrate for quantification of $K$. pneumoniae and E. coli was added prior to transfer to Quanti-trays, which were heat sealed with an IDEXX Quanti-Tray Sealer, and incubated at $35^{\circ} \mathrm{C}$ for 18 hours. K. pneumoniae was quantified by color change, E. coli by fluorescence, and Pseudomonas aeruginosa was run as a negative control. Combined cultures of Enterococcus faecilis and E. faecium were quantified by the IDEXX Enterolert Quanti-Tray enumeration procedure. Blue fluorescence was detected with a UV light, after incubation at $41^{\circ} \mathrm{C}$ for 24 hours. For both Quanti-Tray enumeration procedures, MPN/100 $\mathrm{ml}$ was calculated from the most probable number (MPN) tables provided by the manufacturer, and converted to MPN/ml, using the appropriate dilution. When no wells were positive, a value of one was used for calculations (expressed as $<$ value accounting for dilution). Because testing was performed on salt water specimens, the procedure for marine water samples was followed and specimens were diluted at least tenfold with sterile distilled water, i.e. $10 \mathrm{mls}$ of sample in the final volume of $100 \mathrm{mls}$ was the lowest dilution. Untreated cultures of these organisms were run as positive controls, and tap water was run as a negative control. For V. cholerae, aliquots for all time points were added to disposable glass tubes containing sodium thiosulfate at a final concentration (after adding treated specimen) of $0.81 \mathrm{mM}$. Serial dilutions were performed in dilution buffer containing 2.00 $\mathrm{mM}$ magnesium chloride $\left(\mathrm{MgCl}_{2} \cdot 6 \mathrm{H}_{2} \mathrm{O}\right)$ and $0.312 \mathrm{mM}$ potassium phosphate $\left(\mathrm{KH}_{2} \mathrm{POB}_{4}\right)$, and 100-1000 ul was transferred to nutrient agar (Remel brand, Lenexa, KS) plates and spread using a glass spreader. The plates were incubated for 7 days at $35{ }^{\circ} \mathrm{C}$, at which time colonies were counted, and expressed as CFUs/ml. For kinetics, four experiments were run for each organism, and the Chick-Watson kinetic model coefficients were obtained for each 
experiment by the method of Metcalf and Eddy (2003), using Microsoft Excel spreadsheets. The Hom's model coefficients were calculated by the method of the American Water Works Association (1999), using multiple linear regression and SPSS statistical software. The oxidant demand coefficients were determined by combining the experimental data for each organism and calculating the coefficients in equation 12 by linear regression for contact times of 1, 5, 15, and 30 mins., using Microsoft Excel. The x-intercept (initial oxidant demand) is solved from the equation for the linear regression, with appropriate conversions from the log values. Slopes were compared by hypothesis testing in regression by the method of Helsel and Hirsch (2002), using a standard Student's t table.

The effect of salinity was investigated by dividing a washed E. coli suspension, and bringing it up to equal volumes of either $36 \mathrm{ppt}$ or $10 \mathrm{ppt} \mathrm{IO.} \mathrm{Various} \mathrm{dosages} \mathrm{of} \mathrm{ferrate}$ ranging from $0.25-5 \mathrm{mg} / 1$ were added and sampled at various times. Untreated controls were sampled at the same times for the two salinities, to control for differences in mortality due to salinity without the addition of ferrate, and sodium thiosulfate was also added to untreated controls. The delta log removals were calculated by subtracting untreated controls from the treated controls for each salinity over time. Similarly, the effect of $\mathrm{pH}$ was tested by preparing a washed E. coli suspension in IO as described above, and measuring the initial $\mathrm{pH}$. One portion of the suspension was then adjusted to a $\mathrm{pH} 1.5$ units higher than the initial $\mathrm{pH}$ with $1 \mathrm{~N}$ sodium hydroxide, and one portion was adjusted to a $\mathrm{pH} 1.5$ units lower than the initial $\mathrm{pH}$ with $1 \mathrm{~N}$ hydrochloric acid. Two ferrate dosages, 0.75 and $1.5 \mathrm{mg} / \mathrm{L}$, were tested at various times for the three $\mathrm{pHs}$, and untreated controls were also sampled for each of the conditions (initial $\mathrm{pH}$, acidic $\mathrm{pH}$, and alkaline $\mathrm{pH}$ ) to adjust for any disinfection effects resulting from the changes in starting $\mathrm{pH}$ alone. Delta log removals due to the effect of 
ferrate were calculated for each of the $\mathrm{pH}$ conditions and dosages by subtracting the change in MPN for the untreated control from the corresponding treated condition. Salinity and $\mathrm{pH}$ experiments were done in duplicate with separate ferrate batches. The statistical significance of $\mathrm{pH}$ and salinity effects was determined using a fixed effect ANOVA of a multi-factorial design in S-PLUS 2000, using time, dosage, and $\mathrm{pH}$ or salinity as independent variables. Anti-clumping effects were investigated by washing E. coli three times with IO, as described above, and then either including a low-speed centrifugation (170g for $5 \mathrm{~min}$ ) and resuspension of the supernatant in an appropriate volume of IO, or intense vortexing after addition of ferrate and just before each sampling event. These were done as two separate experiments and compared simultaneously with normal preparation and treatment, i.e. washing the bacterial culture three times with $\mathrm{IO}$ and resuspension in IO, and shaking the specimens prior to sampling. The statistical significance of anti-clumping measures was determined by again using a fixed effect ANOVA of a multi-factorial design in S-PLUS 2000, using time, dosage, and anti-clumping measure (low-speed centrifugation or vortexing vs. normal preparation) as independent variables. Regrowth was measured by growing and resuspending E. coli in IO, as above, dosing with 0,5 , or $10 \mathrm{mg} / 1$ ferrate for one minute, then quenching with sodium thiosulfate, and quantifying at $15 \mathrm{~min}$. Glucose was added to aliquots from each of these conditions, to a final concentration of $0.2 \mathrm{mg} / \mathrm{l}$, and bacteria were re-quantified at 48 hours. 


\subsection{Results and Discussion}

Log Reductions and Kinetics. The average log reductions achieved at 5 minutes for a 5 $\mathrm{mg} / \mathrm{l}$ dosage for the test organisms are summarized in Table 1 . The number of observation (n) used to obtain these values are given in parentheses for this and subsequent tables. The $\mathrm{MPN} / \mathrm{ml}$ at various times and dosages for a typical experiment are shown in Figure 1. The corresponding log-log graph of contact time versus survival is shown in Figure 2, to obtain the contact times necessary to obtain a 4-log reduction for each dosage, following Metcalf and Eddy's (2003) procedure for determining the Chick-Watson coefficients, as described in the Methods section. The resultant coefficients for the Chick-Watson and Hom's models for the four organisms are summarized in Table 2, as well as the correlation coefficients. The fact that $\mathrm{m}$ does not equal one for any of the organisms indicates deviations from Chick's

Table 1: Log reductions for test organisms for $5 \mathrm{mg} / \mathrm{l}$ ferrate dose for $5 \mathrm{~min}$ contact time.

\begin{tabular}{|l|r|r|}
\hline Organism & $\begin{array}{r}\text { Mean Log } \\
\text { Reduction }\end{array}$ & $\begin{array}{r}\text { Standard } \\
\text { Deviation }\end{array}$ \\
\hline E. coli $(\mathrm{n}=4)$ & 6.8 & 0.3 \\
K. pneumoniae $(\mathrm{n}=4)$ & 7.3 & 0.8 \\
Enterococci $(\mathrm{n}=4)$ & 5.5 & 0.5 \\
V. cholerae $(\mathrm{n}=4)$ & 4.4 & 0.2 \\
\hline
\end{tabular}




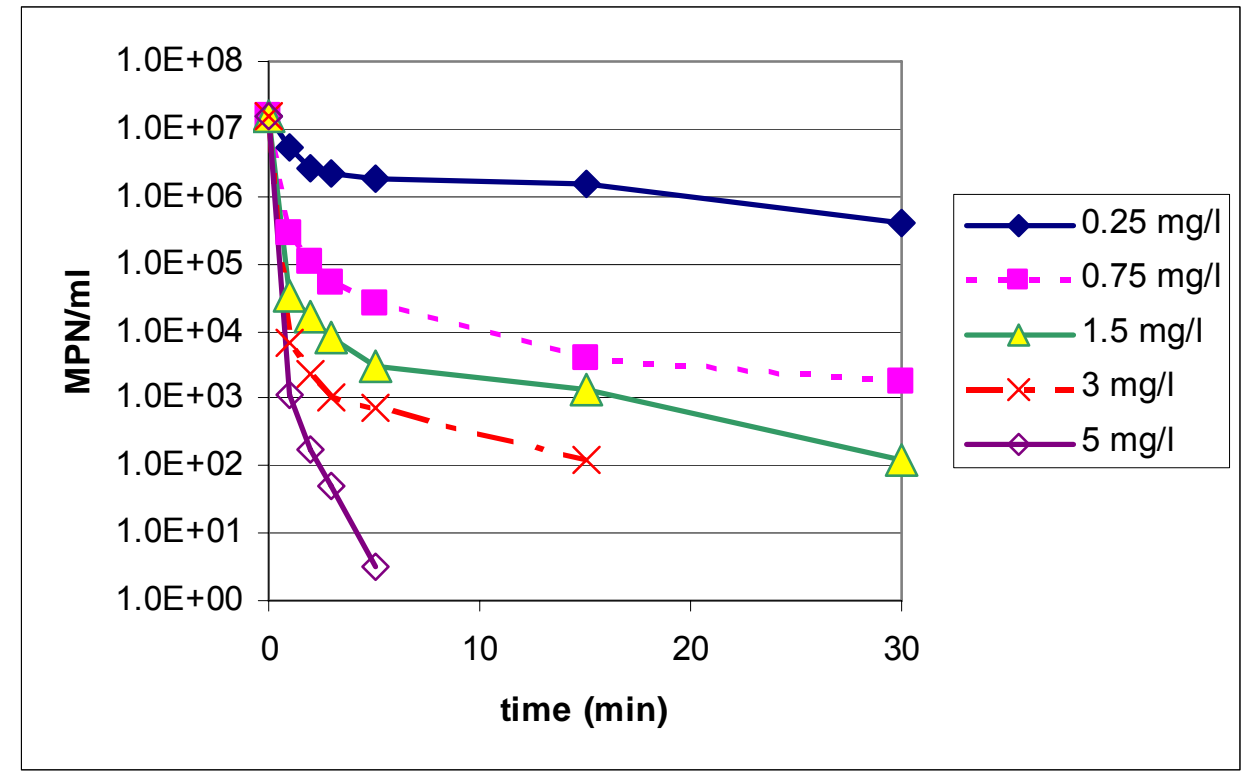

Figure 1: Effect of Ferrate Dosage on E. coli MPN over Time: Results of One Experiment.

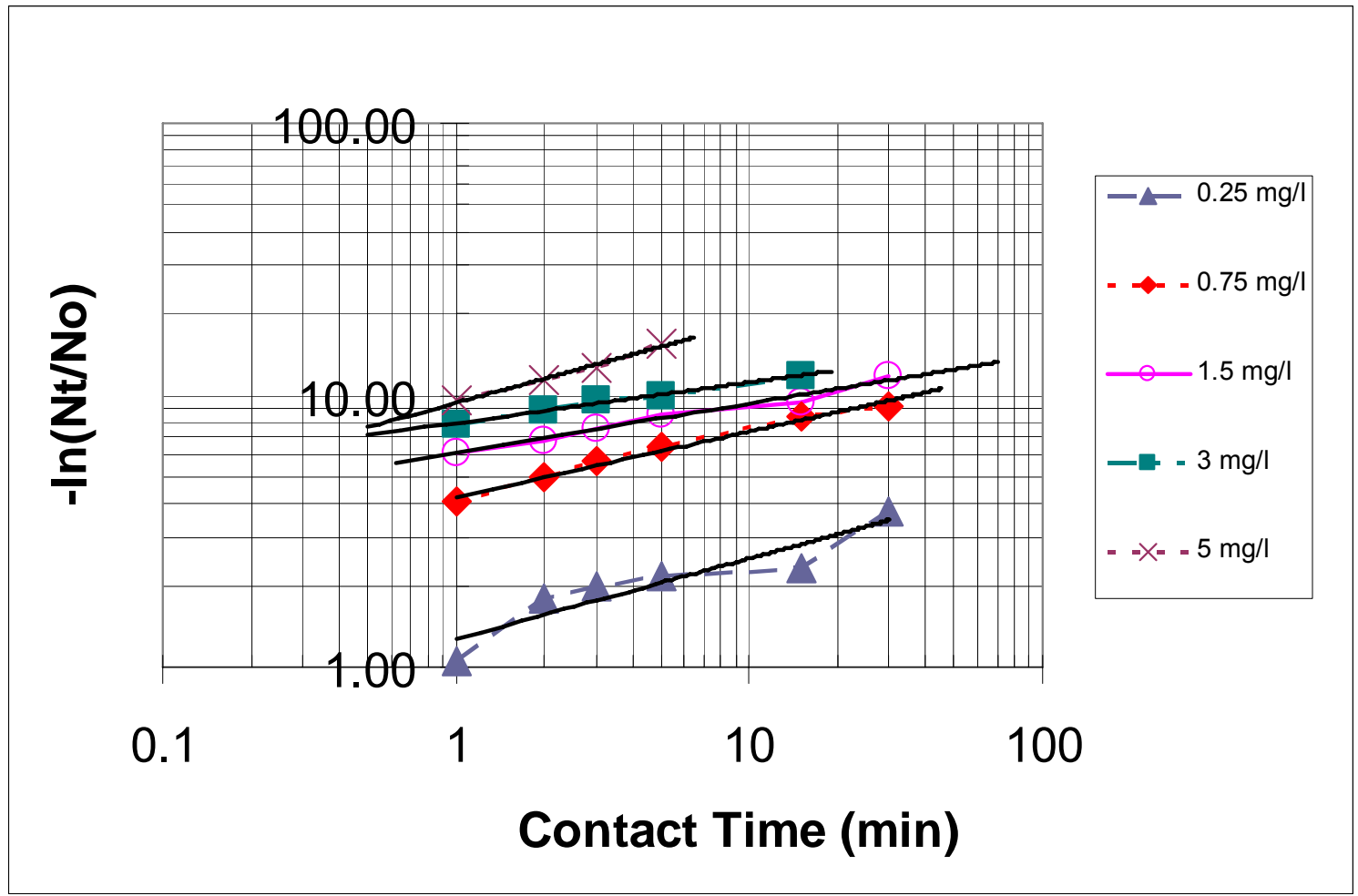

Figure 2: Chick-Watson Analysis of $E$. coli Disinfection Experiment: Results of One Experiment. 
Table 2: Coefficients of the Two Kinetic Models for Ferrate on the Study Organisms.

\begin{tabular}{|r|ccc|cccc|}
\hline & \multicolumn{3}{|c|}{ Chick-Watson Coefficients $^{1}$} & \multicolumn{4}{c|}{ Hom Coefficients $^{1}$} \\
\cline { 2 - 8 } Organism & $\mathrm{n}$ & $\mathrm{k}^{\prime}$ & $\mathrm{R}$ & $\mathrm{n}$ & $\mathrm{m}$ & $\mathrm{K}$ & $\mathrm{R}$ \\
\hline & 2.1 & $0.9+/-$ & 0.78 & 0.5 & 0.2 & 5.4 & 0.96 \\
E. coli & $+/-0.3$ & 0.4 & $+/-0.04$ & $+/-0.2$ & $+/-0.04$ & $+/-1.5$ & $+/-0.02$ \\
& $(\mathrm{n}=80)$ & $(\mathrm{n}=80)$ & $(\mathrm{n}=110)$ & $(\mathrm{n}=110)$ & $(\mathrm{n}=110)$ & $(\mathrm{n}=110)$ & $(\mathrm{n}=110)$ \\
$\mathrm{K}$ & 5.4 & $0.013+/-$ & 0.67 & 0.8 & 0.2 & 2.9 & 0.97 \\
pneumoniae & $+/-1.1$ & 0.009 & $+/-0.08$ & $+/-0.2$ & $+/-0.03$ & $+/-0.8$ & $+/-0.01$ \\
& $(\mathrm{n}=88)$ & $(\mathrm{n}=88)$ & $(\mathrm{n}=112)$ & $(\mathrm{n}=112)$ & $(\mathrm{n}=112)$ & $(\mathrm{n}=112)$ & $(\mathrm{n}=112)$ \\
& 2.4 & $0.3+/-$ & 0.78 & 0.7 & 0.3 & 3.0 & 0.96 \\
Enterococci & $+/-0.2$ & 0.3 & $+/-0.06$ & $+/-0.1$ & $+/-0.08$ & $+/-0.9$ & $+/-0.02$ \\
& $(\mathrm{n}=84)$ & $(\mathrm{n}=84)$ & $(\mathrm{n}=108)$ & $(\mathrm{n}=108)$ & $(\mathrm{n}=108)$ & $(\mathrm{n}=108)$ & $(\mathrm{n}=108)$ \\
& 3.1 & $0.034+/-$ & 0.72 & 0.4 & 0.15 & 4.0 & 0.95 \\
V. cholerae & $+/-0.3$ & 0.02 & $+/-0.05$ & $+/-0.02$ & $+/-.01$ & $+/-0.3$ & $+/-0.02$ \\
& $(\mathrm{n}=63)$ & $(\mathrm{n}=63)$ & $(\mathrm{n}=108)$ & $(\mathrm{n}=108)$ & $(\mathrm{n}=108)$ & $(\mathrm{n}=108)$ & $(\mathrm{n}=108)$ \\
\hline
\end{tabular}

${ }^{1}$ Means and SDs of 4 experiments/organism.

Law. The shape of the dosage-response curves and the observation that all of the Hom's m coefficients are less than one indicates that tailing is occurring. Furthermore, a ChickWatson $\mathrm{n}$ coefficient of greater than 1 indicates that dosage is more important than time, which is what is observed for all organisms.

The coefficients and correlations obtained from the oxidant demand equation are summarized in Table 3. The fact that the initial oxidant demand (x-intercept) values are highest for 1-min contact times indicates that the initial oxidant demand had not been met until the later contact times. Our slope or b values $(2.1-6.5)$ are considerably higher than those of Oemcke and van Leeuwen (2005) $(0.2-0.5)$, which theoretically indicates greater inactivation at lower dosages, but it is not valid to compare rates of inactivation of bacteria with a dinoflaggelate algae, and the uncommon use of this equation limits other comparisons. The $b$ coefficient is fairly consistent for each organism at the various contact times.

Comparing slopes for each organism at the different contact times, at the $p=0.05$ level, the 1-min. contact time is different from at least one other time for each organism, perhaps again suggesting that the initial oxidant demand had not been satisfied yet for this contact time. 
Table 3: Coefficients for the Oxidant Demand Equation for Ferrate on the Study Organisms.

\begin{tabular}{|c|c|c|c|c|c|}
\hline Organism & $\begin{array}{l}\text { Time } \\
\text { (min) }\end{array}$ & b & d & $\mathbf{R}$ & $\begin{array}{r}\text { Initial } \\
\text { Demand }\end{array}$ \\
\hline \multirow{4}{*}{ E. coli } & $1(n=20)$ & 3.06 & 2.43 & 0.96 & 0.16 \\
\hline & $5(n=20)$ & 4.23 & 3.60 & 0.97 & 0.14 \\
\hline & $15(n=18)$ & 4.54 & 4.02 & 0.97 & 0.13 \\
\hline & $30(n=12)$ & 4.98 & 4.44 & 0.98 & 0.13 \\
\hline \multirow{4}{*}{$\begin{array}{l}\text { K. } \\
\text { pneumoniae }\end{array}$} & $1(n=20)$ & 5.27 & 1.08 & 0.97 & 0.62 \\
\hline & $5(n=20)$ & 6.06 & 2.23 & 0.93 & 0.43 \\
\hline & $15(n=20)$ & 6.51 & 2.52 & 0.95 & 0.41 \\
\hline & $30(n=12)$ & 5.55 & 2.83 & 0.93 & 0.31 \\
\hline \multirow{4}{*}{ Enterococci } & $1(n=20)$ & 2.79 & 1.76 & 0.88 & 0.23 \\
\hline & $5(n=20)$ & 3.53 & 2.75 & 0.95 & 0.17 \\
\hline & $15(n=16)$ & 3.42 & 3.04 & 0.95 & 0.13 \\
\hline & $30(n=12)$ & 3.71 & 3.32 & 0.94 & 0.13 \\
\hline \multirow{4}{*}{ V. cholerae } & $1(n=20)$ & 2.10 & 1.78 & 0.94 & 0.14 \\
\hline & $5(n=20)$ & 2.56 & 2.54 & 0.98 & 0.10 \\
\hline & $15(n=16)$ & 2.44 & 2.76 & 0.95 & 0.07 \\
\hline & $30(n=12)$ & 2.66 & 2.94 & 0.92 & 0.08 \\
\hline
\end{tabular}

The only other slopes that differ significantly are the 5 and 30-min contact times for E. coli, suggesting again the importance of dosage. This equation is not a rate equation, as is ChickWatson and Hom's, and in fact only relates survival as a function of dosage for a given contact time. Also, because it is necessary to calculate coefficients for each contact time, this approach seemed more cumbersome than the Hom's model. Furthermore, the consistently higher correlation coefficients obtained with the Hom's equations, summarized in Table 4,

Table 4: Correlation Coefficients for the Disinfection Equations

\begin{tabular}{|l|r|r|r|}
\hline \multirow{2}{*}{ Organism } & \multicolumn{3}{|c|}{ R values for the Disinfection Modeling Equations } \\
\cline { 2 - 4 } & Hom's & Chick-Watson & Oxidant Demand \\
\hline E. coli & 0.96 & 0.78 & $0.96-0.98$ \\
\hline K. pneumoniae & 0.97 & 0.67 & $0.93-0.97$ \\
\hline Enterococci & 0.96 & 0.79 & $0.88-0.95$ \\
\hline V. cholerae & 0.95 & 0.72 & $0.92-0.98$ \\
\hline
\end{tabular}


indicate that the 3-parameter model is necessary to adequately model the data. Therefore, the following equations best predict the effect of ferrate on the test organisms:
E. coli
$\ln \mathrm{S}=-5.4 \mathrm{C}^{0.5} \mathrm{t}^{0.2}$
K. pneumoniae $\ln \mathrm{S}=-2.9 \mathrm{C}^{0.8} \mathrm{t}^{0.2}$
Enterococci $\quad \ln \mathrm{S}=-3.0 \mathrm{C}^{0.7} \mathrm{t}^{0.3}$
V. cholerae $\quad \ln \mathrm{S}=-4.0 \mathrm{C}^{0.4 \mathrm{t}^{0.2}}$

where $\mathrm{t}$ is time in minutes, $\mathrm{C}$ is initial ferrate concentration in $\mathrm{mg} / \mathrm{l}$, and $\mathrm{S}$ is survival of the $\operatorname{organism}\left(\mathrm{N}_{\mathrm{t}} / \mathrm{N}_{0}\right)$.

These equations result in the times required to obtain a 4-log reduction over a range of ferrate dosages, presented in Table 5. K. pneumoniae demonstrates the greatest dependence on dosage, as evidenced by the relatively large ratio of times required to achieve 4-log reductions at the low and high dosages in Table 5, summarized in Table 6.

Table 5: Time (in minutes) to Obtain a 4-Log Reduction of the Organisms (extrapolated from experimental data using Hom's model coefficients).

\begin{tabular}{|r|r|r|r|r|}
\hline \multirow{2}{*}{$\begin{array}{l}\text { Ferrate Dosage } \\
\text { (mg/l) }\end{array}$} & \multicolumn{5}{|c|}{ Organism } \\
\hline
\end{tabular}


Table 6: Ratio of Time Required to Obtain a 4-Log Reduction at 0.1 and $5.0 \mathrm{mg}$ / Ferrate.

\begin{tabular}{|c|r|r|r|}
\hline \multicolumn{4}{|c|}{ Organism } \\
\hline E. coli & $\begin{array}{c}\text { K. } \\
\text { pneumoniae }\end{array}$ & Enterococci & $\begin{array}{c}\text { V. } \\
\text { cholerae }\end{array}$ \\
\hline 15216 & 6462766 & 9061 & 2489 \\
\hline
\end{tabular}

As mentioned, the observation that all of the Hom's m coefficients are less than one and that all of the Chick-Watson $\mathrm{n}$ coefficients are greater than one indicates that dosage is more important than time. Haas and Karra (1984) reviewed a number of disinfection studies conducted under demand-free conditions, determined by chemical analyses of the residual, and found that free chlorine generally produced Chick-Watson $\mathrm{n}$ values greater than 1 (i.e. tailing), whereas $n$ values of less than 1 (i.e. shoulders) were observed with combined chlorine. However, most of the studies they examined were at lower (2-3) log reductions than this study, which also was not done under demand-free conditions. They observe that the Hom's model did not significantly increase predictive power for most of the experiments, but also note that a less satisfactory agreement with Chick-Watson is likely for higher log reductions, since tailing is a more common occurrence with greater inactivation values. In addition, the $\mathrm{k}$ coefficients are experimental rate constants: the higher the $\mathrm{k}$ value, the lower the survival. The Chick-Watson k' values cited by Haas and Karra for experiments with $E$. coli range from $0.3-30.6$ for free chlorine for $\mathrm{pH}$ values ranging from $7.0-10.7 \mathrm{l} / \mathrm{mg}$-min, and from 2.5 x 10-5 - 1.0 1/mg-min for $\mathrm{pH}$ values from 7.0 - 10.5. The Chick-Watson $\mathrm{n}$ values range from $0.8-1.5$ for free chlorine and from $0-13.3$ for combined chlorine. Thus, this study's $n$ value of 2.1 and the $\mathrm{k}$ value of 0.9 for E. coli is comparable to the values of either of the other disinfectants, given the wide ranges, but a direct comparison is difficult, given the differences in experimental design, particularly the high salinity of this study. 
pH and Salinity. The transferability of these equations to ballast water applications will depend upon several factors, including $\mathrm{pH}$ and salinity. The $\mathrm{pH}$ of seawater is close to that of the bacterial suspensions in IO (approximately 8), but the $\mathrm{pH}$ of ballast water might differ significantly, due to products of corrosion or metabolism of bacteria and other organisms present. The results for a $0.75 \mathrm{mg} / 1$ ferrate dosage, shown in Figure 3, indicate that a slightly acidic $\mathrm{pH}$ (6.5) enhanced disinfection. Results for $1.5 \mathrm{mg} / \mathrm{l}$ ferrate (not shown) were similar ( $\mathrm{p}<0.001$ for acidic $\mathrm{pH}$ for both dosages), whereas an alkaline $\mathrm{pH}$ had a much smaller effect ( $p>0.05$ for both dosages). However, at the $0.75 \mathrm{mg} / \mathrm{l}$ dosage, the $\mathrm{p}$ value of alkaline vs. starting $\mathrm{pH}$ was 0.07 , and log reductions appeared to be increasing with time relative to the neutral $\mathrm{pH}$. The effect of the $\mathrm{pH}$ change itself was minor for the acidic conditions (a 0.09 log change over the experimental time of 30 minutes) but slightly higher (a $0.25 \mathrm{log}$ reduction) for the alkaline condition. This effect has been subtracted from the effect of ferrate for each time point, as described in the Methods section, to determine the log removals shown in Figure 3. These results are consistent with the higher reduction potential of ferrate in acidic solution, but the effects of the increased stability of ferrate in alkaline solution are less clear, and perhaps are being confused by the higher mortality from alkaline $\mathrm{pH}$ and the small sample size (two experiments). Salinity did not have a clear effect on log reductions $(\mathrm{p}>0.05)$, as shown in Figure 4. 


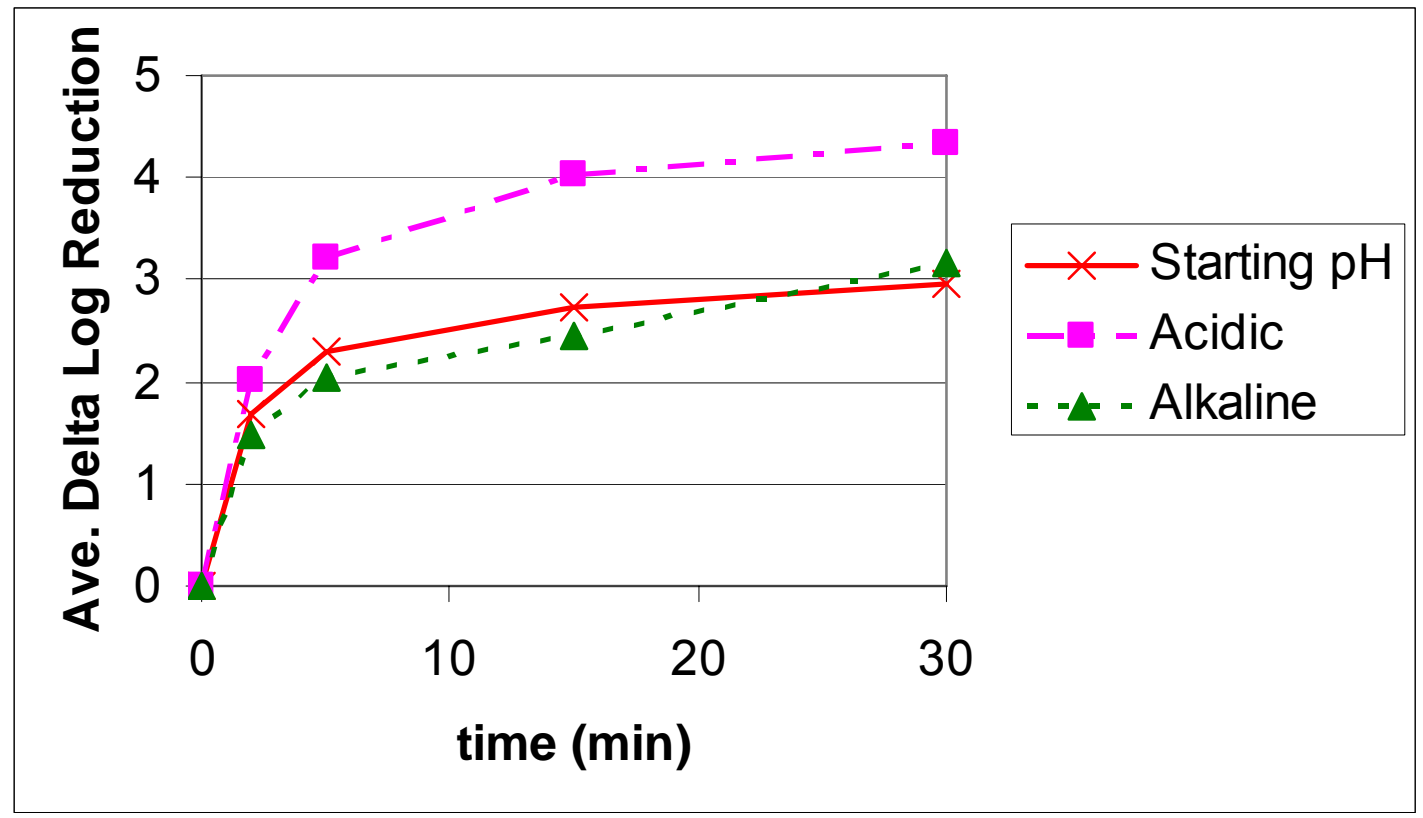

Figure 3: Effect of pH on Log Reduction of E. coli by $0.75 \mathrm{mg} / \mathrm{l}$ Ferrate (averages of 2 experiments).

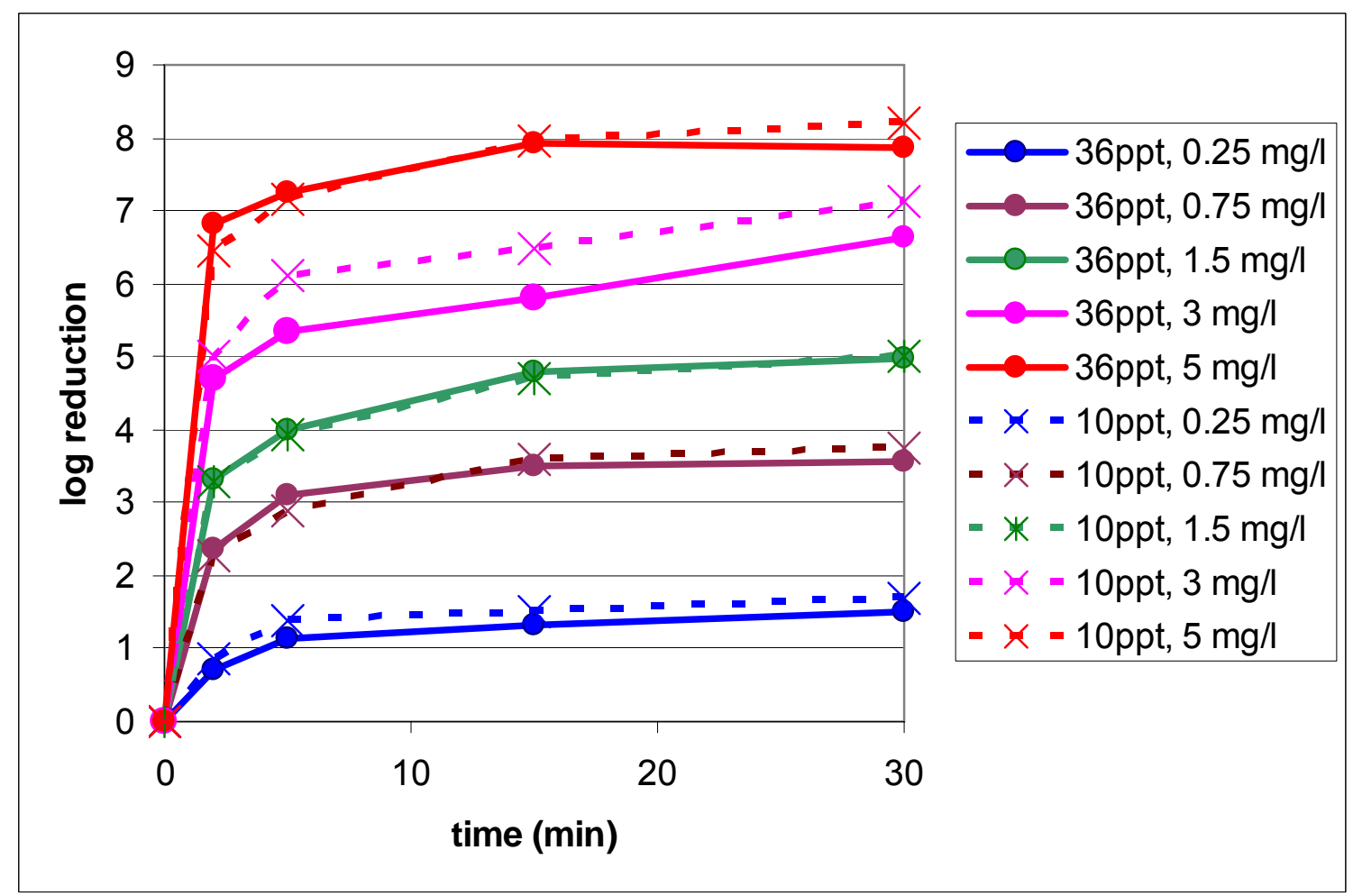

Figure 4: Effect of Salinity on E. coli Mortality at Various Ferrate Dosages (averages of 2 experiments). 
Initial Bacterial Concentration $\left(\mathbf{N}_{\mathbf{0}}\right)$. Because the starting bacterial concentration represents an oxidant demand, this also has a potential impact on disinfectant dosage, but the literature on this subject is somewhat contradictory. Rincon and Pulgarin (2004), for example, found that as $\mathrm{N}_{0}$ increased, the time for inactivation of $E$. coli with illuminated $\mathrm{TiO}_{2}$ (photocatalysis) increased, or in other words, efficiency of disinfection decreased. Likewise, Greets and Fomichev (1985) found that the disinfection efficiency of ozone on E. coli and P. aeruginosa (and their phages) improved with a decrease in their initial concentration, and that disinfection seemed to be a function of the concentration of ozone per bacterial cell. On the other hand, Haas and Kaymak (2003) found that as $\mathrm{N}_{0}$ decreased, the disinfection efficiency of ozone against Giardia muris decreased. Figure 5 indicates that a reduction in starting concentration of $K$. pneumoniae corresponded with an increase in log kill by a $1 \mathrm{mg} / 1$ ferrate dose. The initial bacterial concentration $\left(\mathrm{N}_{0}\right)$ was $5.3 \times 10^{7}$ organisms $/ \mathrm{ml}$, and there was a particularly significant increase in log kills with the first $\log$ dilution at 5 minutes. After this the log kills seemed to stabilize, although the results at the final time of measurement (10 min. of additional kill, for a final time of $15 \mathrm{~min}$ ) increased in a linear fashion with dilution until the 1:1000 dilution. This is probably because the final dilution of $1: 1000 \mathrm{~N}_{0}$ resulted in no bacteria detected at the end time, and this was counted as 1 organism according to the procedure outlined in the Methods section, and multiplied by 1000 for the dilution, resulting in the log reduction shown. Thus, the decrease in log reduction for the final dilution appeared to be attributable to the decrease in bacteria available to kill, i.e. the log kill began to decrease simply because there were fewer bacteria to kill. Similar results with respect to the effect 


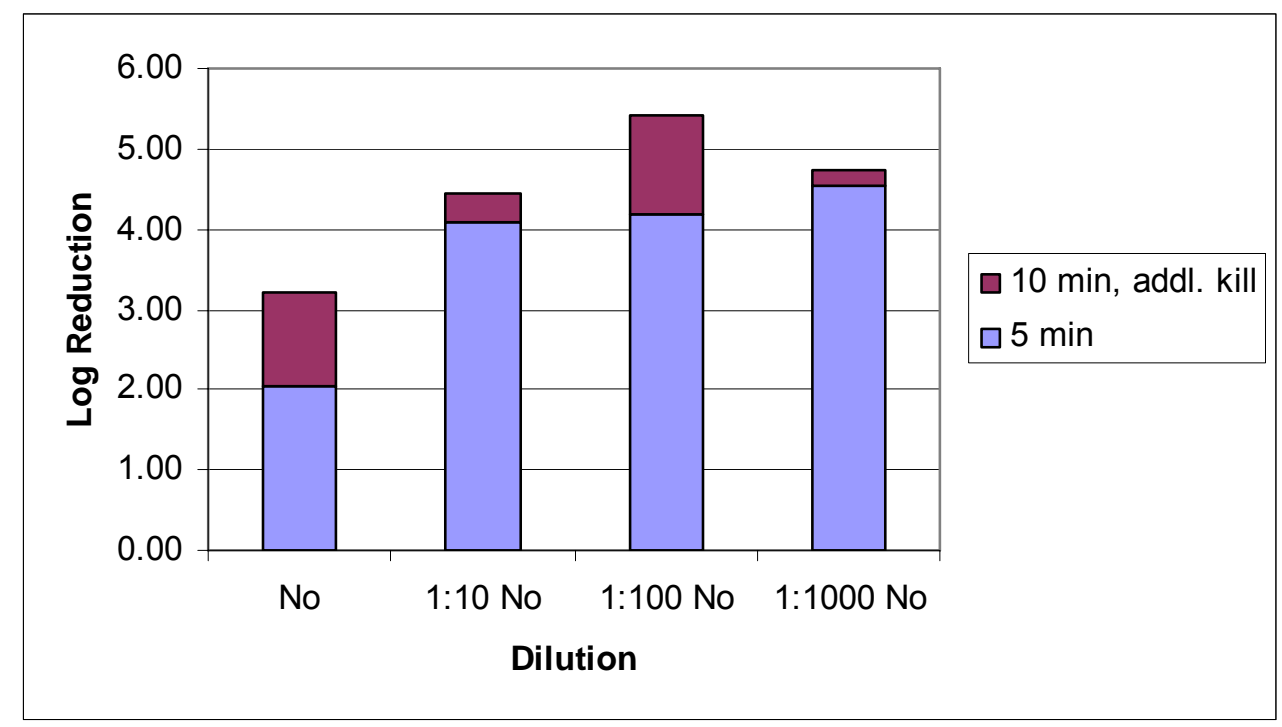

Figure 5: Effect of Initial $K$. pneumoniae Concentration on Effectiveness of a 1 mg/l Ferrate Dosage.

of initial bacterial concentration were obtained for E. coli (data not shown). The data indicates that the log kill achieved with a given contact time and dosage decreased as initial bacterial concentration increased. The initial values used in this study were conservative in that they were quite high (approximately $10^{7} \mathrm{MPN} / \mathrm{ml}$ for E. coli and $\mathrm{K}$. pneumoniae, and $10^{5} \mathrm{MPN} / \mathrm{ml}$ for Enterococci). Initial studies by this research group found an MPN for E. coli of less than 1 per $\mathrm{ml}$ in two locations in waters of the Port of Cape Canaveral, approximately seven orders of magnitude lower than our initial concentrations. Therefore, our estimated dose would be higher than the actual requirement to inactivate the organisms to the required standard.

However, in other countries, researchers are finding higher concentrations of organisms in ballast water, with a great deal of variability. For example, specific oligonucleotide probe analysis of six ballast waters in Singapore Harbour found concentrations of eubacteria, Enterobacteria, Vibrio spp, and E. coli ranging from $10^{4}$ to $10^{6}$ cells $/ \mathrm{ml}$ for each of these organism classes (Joachimsthal et al, 2004). It is possible 
that holding water promotes breeding of bacteria, but the same team of researchers found slightly lower concentrations in ballast water relative to seawater, and hypothesized that ballast water creates an environment that favors facultative anaerobic bacteria, which might also favor pathogens (Joachimsthal et al, 2003). Therefore, our starting bacterial concentrations might be comparable to, or perhaps slightly higher than, typical ballast water concentrations. Furthermore, the ferrate demand in ballast water due to oxidantdemanding compounds, including inorganics such as corrosion products, and organics needs to be assessed to translate results into the field, along with field testing in a variety of locations.

Anti-clumping. The observation of tailing indicates that clumping of cells might have occurred in the experiments. To investigate this possibility, two anti-clumping proceduresa low-speed centrifugation to remove clumps and intense vortexing-were compared to the standard procedure. The results are presented in Figures 6 and 7. Neither procedure eliminated the observation of tailing, but both procedures appeared to improve the log reductions $(\mathrm{p}<0.05)$ over the "normal" preparation. There was a procedural bias in that the anti-clumping procedure was performed before the "normal" preparation procedure, using 


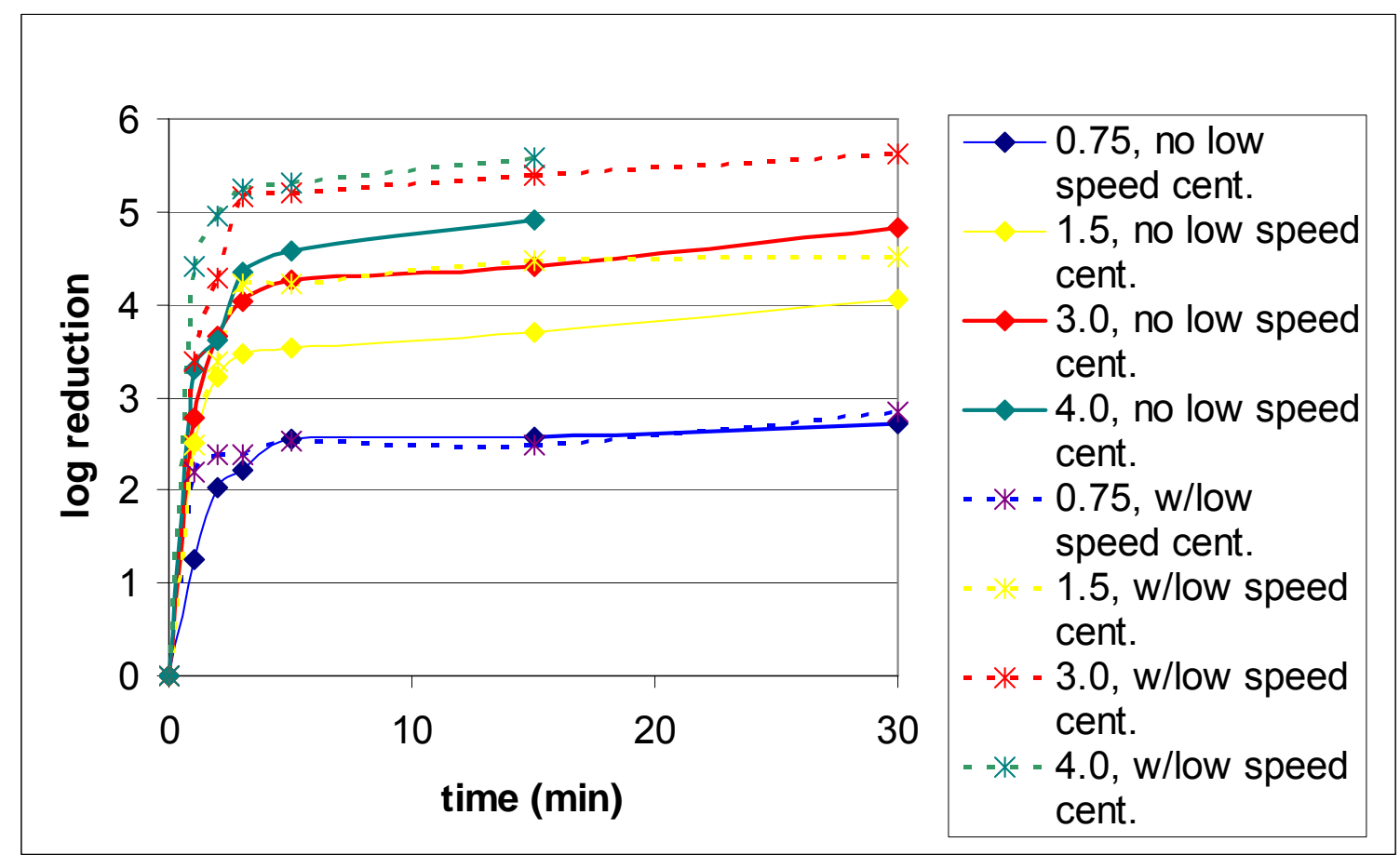

Figure 6: Effect of Low Speed Centrifugation to Remove Clumps.

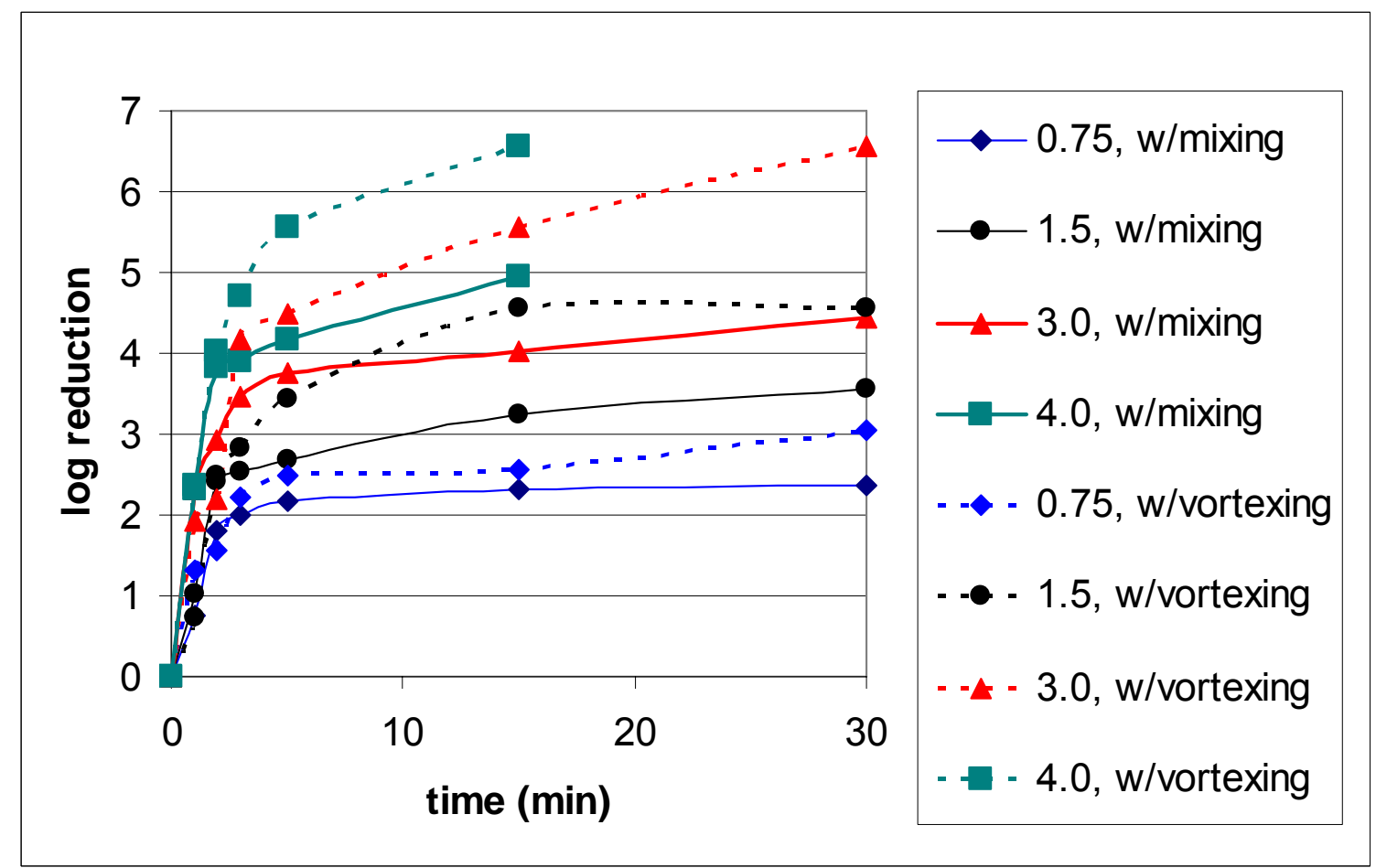

Figure 7: Effect of Vigorous Vortexing to Reduce Potential Clumping. 
the same batch of ferrate to eliminate any variability between batches. This meant that if ferrate dissipated during the intervening time the actual dose received by the "normal" preparation would be lower. However, a preliminary study by this lab found ferrate to be stable for hours at $20^{\circ} \mathrm{C}$, suggesting that this effect was probably minimal. However, because of the additional step of the low-speed centrifugation, it was impossible to control for $\mathrm{N}_{0}$ in this comparison, since part of the biomass was removed in centrifugation relative to the "normal" preparation. Because of the anticipated removal of some of the bacteria in this step, this procedure was conducted with three times the volume relative to the "normal" preparation, which resulted in a higher $\mathrm{N}_{0}$ for the low-speed centrifugation procedure than the "normal" preparation ( $4.9 \times 10^{6}$ vs. $1.5 \times 10^{6} \mathrm{MPN} / \mathrm{ml}$, respectively. $)$ Although the log reductions are expressed relative to the starting concentration for that condition, $\mathrm{N}_{0}$ is a variable that could have affected the results, as discussed above. However, since centrifugation had a higher initial concentration this difference could not explain the increased log removals observed. This is supported by the fact that vortexing increased removals even though this procedure did not significantly affect the initial bacterial concentration (Figure 7).

Regrowth from a viable but not culturable state. Lastly, possible regrowth of $E$. coli was investigated. Figure 8 summarizes the average results of two experiments. The short contact time of $1 \mathrm{~min}$ with a high ferrate dosage of $10 \mathrm{mg} / 1$ resulted in irreversible kill, with no regrowth, even with the addition of glucose. The same contact time with a ferrate dose of $5 \mathrm{mg} / \mathrm{l}$ did not produce a complete kill, but the number of bacteria continued to decline following the exposure to ferrate, even with the addition of glucose, indicating irreparable damage to the organisms. However, the population with glucose 
declined at a slower rate than did the population without glucose, indicating at least some metabolic activity. The data imply that at the higher doses the bacteria were probably killed rather than temporarily impaired and not metabolically active in the enumeration method, but at $5 \mathrm{mg} / \mathrm{l}$ there were still some potentially viable organisms. Neither of the disinfected samples showed a rebound in E. coli numbers, whether substrate was added or not.

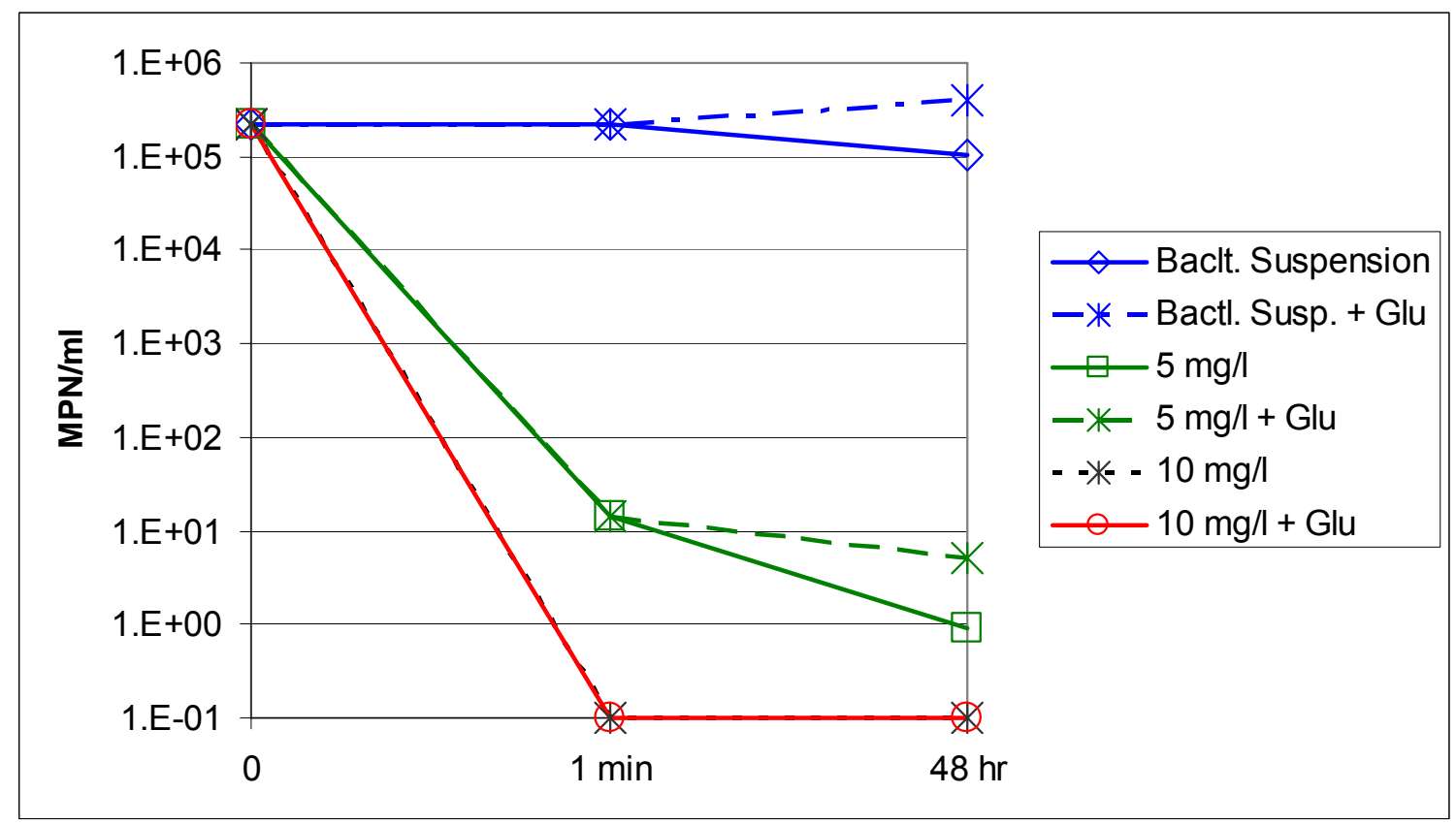

Figure 8: Regrowth of $E$. coli after Ferrate Exposure (average of 2 experiments).

\section{Comparison with Alternative Ballast Water Treatment Processes. The}

attractiveness of ferrate as a disinfectant for ballast water requires a comparison with other disinfectants, and the problem of ANS has spurred recent studies of disinfection of seawater. Azanza et al (2001) measured the decimal reduction times (D-values), which is the time to achieve a one-log reduction, of $E$. coli in seawater in response to treatment with ultraviolet (UV) radiation and with chlorine. At $35 \mathrm{ppt}$ salinity and $25^{\circ} \mathrm{C}$, they obtained a D-value of 
2.0-2.7 min for a $0.5 \mathrm{ppm}$ dosage of chlorine, and a D-value of $0.23-0.37 \mathrm{~min}$ for $\mathrm{UV}$ radiation at a dosage of $16 \mathrm{mWs}^{-1} \mathrm{~cm}^{-2}$. Substituting this dosage of ferrate and this level of survival into our Hom's equation for E. coli (Equation 13), we obtain a D-value of $0.1 \mathrm{~min}$, which is superior to their values. Oemcke et al (2004) obtained 2- to 3-log reductions at somewhat higher UV doses. The hydroxyl radical, generated by ionization of seawater using a strong electric field, produced at least 2-log reductions of microorganisms (Bai et al, 2003), and heating of ballast water also shows early potential as a ballast water disinfectant (Rigby et al, 2002). Ferrate shows potential as an effective oxidant for ballast water, and merits additional study, as well as cost-effectiveness comparisons with the alternatives after required dosages for all candidates are established.

\subsection{Conclusions and Recommendations}

A dosage of $5 \mathrm{mg} / \mathrm{l}$ ferrate was sufficient to achieve the international standards of less than $1 \mathrm{CFU} / 100 \mathrm{mls}$ for $V$. cholerae, less than $2.5 \mathrm{CFUs} / \mathrm{ml}$ for $E$. coli, and less than 1 $\mathrm{CFU} / \mathrm{ml}$ for Enterococci, with our experimental initial concentrations of at least $10^{4}$ bacteria/ml and very short contact times, and 4 log removals could be achieved for all organisms with a ferrate dosage of $2 \mathrm{mg} / \mathrm{l}$ and a contact time of at least 20 minutes. Both the Chick-Watson and Hom's models indicate that dosage is more important than time, and the Hom's model was superior in predicting the action of ferrate. The tailing effect that was consistently observed in the dosage-response curves suggests that ferrate decomposes rapidly, a desirable trait for subsequent release into the receiving water body, and the natural alkalinity of seawater favors precipitation of the remaining iron for later removal with the 
ballast tank sludge, if needed to comply with iron discharge standards,. The disinfection properties of ferrate need to be validated under a variety of field conditions, including a range of initial bacterial concentrations and organic content, but they appear to be significant with various $\mathrm{pH}$ values and salinities. Ferrate compares favorably with other candidates for ballast water treatment, and shows promise as an environmentally-friendly, effective disinfectant. 


\section{CHAPTER 4 - CONCLUSIONS}

All three organisms listed in the international standards for ballast water managementE. coli, Vibrio cholerae, and Enterococci-were tested. A dosage of $5 \mathrm{mg} / 1$ ferrate was sufficient to achieve the international standards of less than $1 \mathrm{CFU} / 100 \mathrm{mls}$ for V. cholerae, less than $2.5 \mathrm{CFUs} / \mathrm{ml}$ for E. coli, and less than $1 \mathrm{CFU} / \mathrm{ml}$ for Enterococci, with our experimental initial concentrations of at least $10^{4}$ bacteria/ml and very short contact times, and four log removals could be achieved for all organisms with a ferrate dosage of $2 \mathrm{mg} / \mathrm{l}$ and a contact time of at least 20 minutes. This combination of dosage and contact time would also result in a 4-log reduction of $K$. pneumoniae, which represented coliforms in this study. K. pneumoniae showed the greatest dependence on dosage rather than time, but the international standards do not specify an endpoint for this organism, or for coliforms.

Kinetic modeling with three different equations or models, as well as the CT approach, indicated that the dosage of ferrate was more important than the contact time for all four organisms. A tailing effect was consistently observed, and because the Hom's equation is designed to model tailing and shoulder effects, it yielded the highest correlation coefficients, It was also relatively easy to perform using statistical software, and therefore was superior to the other models. Preliminary testing suggested that the tailing effect was not attributable to clumping. It might be the result of precipitation or decomposition of the ferrate, or to some other mechanism, such as resistant subpopulations. Onboard testing should reveal whether this will be a significant problem. If it is the result of rapid decomposition of ferrate, then this is an advantage for subsequent release into the environment. 
The $2 \mathrm{mg} / \mathrm{l}$ suggested dosage would exceed Florida iron discharge standards, but the natural alkalinity of seawater favors precipitation of the remaining iron within the tank, requiring later removal with ballast tank sludge. It is also possible that lower bacterial concentrations in ballast water will reduce the dosage required, based on the effect of starting bacterial concentration on log reductions noted in Chapter 3 .

The disinfection properties of ferrate need to be validated under a variety of field conditions, including a range of initial bacterial concentrations and organic content, but they appear to be significant with various $\mathrm{pH}$ values and salinities. Ferrate compares favorably with other candidates for ballast water treatment, and shows promise as an environmentallyfriendly, effective disinfectant. 


\section{CHAPTER 5 - RECOMMENDATIONS FOR FUTURE STUDY}

Obviously, an important next step is onboard testing of ferrate for ballast water disinfection. Ideally, results should be correlated with organic content, bacterial types and concentrations, $\mathrm{pH}$ values, temperatures, and other potentially relevant parameters. This would be important not only from a scientific standpoint, but also from a marketing standpoint, in order to extrapolate results to a variety of ballast water conditions encountered worldwide. It is reasonable to expect that field conditions, particularly organic content, might lower observed log reductions, since removal of nutrient broth was required for optimization of experimental procedure (Appendix A). After obtaining acceptable kill rates of a dinoflagellate alga by ozone in ballast water, Oemcke and van Leeuwen (2005) concluded that corrosion products and organic matter in ballast water storage tanks would probably lower efficiency to an unacceptable level, and that the disinfectant would have to be applied during ballast intake. Likewise, ferrate efficiency will depend not only upon field conditions, but also on practical aspects of application.

Precipitation of iron for disposal in the post-treatment sludge should also be explored. This might be necessary to meet simultaneous requirements for disinfection and iron discharge. As mentioned, the maximum iron standard ranges from $0.3-1.0 \mathrm{mg} / 1$ within Florida waters, which might make it problematic to achieve sufficient log reductions, depending on bacterial concentrations, organic content, and other factors and constraints. Also as mentioned, iron release might encourage bacterial, algal, and phytoplanktonic blooms in areas where iron is the limiting nutrient. Although the vast volume of ocean water will undoubtedly dilute this effect, the potential for harmful 
effects on the environment, and certainly the legal discharge standards, must be addressed. An initial study by another graduate student (Adham Mukkatash) indicated approximately an $85 \%$ reduction of ferrate in solution after 30 min at ambient temperature, and the redox equilibria of ferrate favor precipitation, but the iron concentration in solution and in precipitate needs to be established, particularly onboard. The configuration of the onboard ballast water treatment and disposal will probably dictate disinfection optimization. For example, if it is possible to withdraw sediment from the ballast water storage tanks, this might be an easy solution. It might also be easier to treat the ballast intake, as suggested by Oemcke and van Leeuwen (2005), but this might necessitate $100 \%$ kill if conditions in the storage tanks favor bacterial growth.

Another practical aspect of ferrate treatment is the determination of the bacterial community that one would expect to encounter in ballast water. Obviously, this will vary greatly, as researchers are discovering, but can probably be narrowed somewhat for a geographical region. Although all of the test organisms seemed to be susceptible to ferrate disinfection, possibly because of common strategies for iron uptake, as mentioned in Chapter 2, these were relatively homogeneous laboratory cultures. Environmental isolates of Vibrio have different types and amounts of iron-binding proteins (Chapter 2), but iron uptake by blood-borne strains is better studied than environmental strains, and the uptake of ferrate might differ from that of iron. Ferrate-resistant strains might be encountered in the oceanic environment. Detailed descriptions of the bacterial assemblages, and the relative effectiveness of ferrate on each, would provide interesting scientific information not only on ferrate disinfection, but also on iron uptake by environmental pathogens, and for ballast water researchers worldwide. 
All of the practical considerations mentioned are applicable to almost all disinfection processes, so of course another recommendation is for cost-effectiveness comparisons with other ballast water disinfectant candidates. This will depend on the availability of other cost estimates for other disinfectants, but certainly a first step is estimating costs for ferrate disinfection after establishing onboard requirements. Also, estimates of stability and production variability onboard would assist in the evaluation of ferrate as a ballast water disinfectant, as well as other potential applications.

The tailing effect that was consistently observed remains an interesting and unexplained phenomenon. Experiments to elucidate its cause could prove enlightening. For example, to test for resistant subpopulations, as opposed to the precipitation or reduction of ferrate, the bacteria remaining from one disinfection could be disinfected a second time. Resistant subpopulations should result in much lower log reductions with the second disinfection, whereas higher secondary log reductions would suggest that the original ferrate precipitated, decomposed, or otherwise lost its effectiveness. 
APPENDIX A: EXPERIMENTAL OUTLINE AND OPTIMIZATION 


\section{A.1 Ferrate Experiment Outline}

\section{A.1.1 Preparation of Solutions, Reagents, Materials, and Plates.}

A. Preparation of R2A agar plates:

Dissolve $14.56 \mathrm{~g}$ of R2A agar in $800 \mathrm{mls}$ of distilled water in a $11 \mathrm{flask}$. Heat with stirring to dissolve the agar. Cover loosely and autoclave for 15 minutes at $121^{\circ} \mathrm{C}$. Allow to cool until it is just cool enough to handle comfortably $\left(45-50^{\circ} \mathrm{C}\right)$. Pour about $15 \mathrm{mls}$ of agar into sterile Petri dishes, covering bottom uniformly. Close and allow to solidify for about one hour. Invert and dry overnight, then store in sealed bags at $4^{\circ} \mathrm{C}$.

B. Dilution Buffer

$1.25 \mathrm{ml}$ stock phosphate solution $+5 \mathrm{ml} \mathrm{MgCl-hydrate} \mathrm{solution} \mathrm{in} 11 \mathrm{H}_{2} \mathrm{O}$; autoclave

C. Stock Phosphate Solution

$9.89 \mathrm{~g}$ potassium phosphate $\left(\mathrm{KH}_{2} \mathrm{PO}_{4}\right)$ per 1

D. MgCl-Hydrate solution

$8.11 \mathrm{~g} \mathrm{MgCl}_{2}-6 \mathrm{H}_{2} \mathrm{O}$ per $100 \mathrm{ml}$

E. Sodium Thiosulfate $0.081 \mathrm{M}$

$10 \mathrm{~g}$ NaThiosulfate in $500 \mathrm{mls}$ water; autoclave

F. Instant Ocean (IO): 1/2 cup/gallon, autoclave

G. Sterile water (autoclaved).

H. Nutrient broth (NB)

$8 \mathrm{~g}$ in 11 . Autoclave. 
I. E. Coli, or other organism, pellet started in NB per vendor instructions.

Transfer to IO/NB after appropriate incubation time. Incubate 3-5 days, with gentle rocking. Record $\mathrm{pH}$ and FAUs/NTUs prior to expt.

J. Autoclave flasks, beakers, centrifuge vials, etc.

\section{A.1.2 Ferrate Preparation}

A. Ensure water bath is between water level bars.

B. Dissolve $\mathrm{CaOCl}_{2}$

1. Measure weight of water cylinder, add 9.8-9.9 $\mathrm{g} \mathrm{H}_{2} \mathrm{O}$, re-weigh cylinder.

2. Measure weight of $\mathrm{NaOH}$ cylinder, add 32.5-32.6 g NaOH, re-weigh cylinder.

3. Measure $2.698 \mathrm{~g}$ of $\mathrm{CaOCl}$.

4. Record all results. Exact measures will be used in spreadsheet (ss).

5. Add water, $\mathrm{NaOH}$, and $\mathrm{CaOCl}$ together in reactor. Stir for 90 mins at $7-8$ on dial. Parafilm.

C. Turn on spectrophotometer (switch turns on in 2 steps). Warm up $>=15$ mins.

D. Prepare Boric Solution

$0.7098 \mathrm{~g}$ di-sodium hydrogen phosphate (anhydrous) $+0.3814 \mathrm{~g}$ sodium tetraborate decahydrate in 11 vol. flask.

E. Get computer/spectrophotometer ready. Go to $001 \mathrm{chem}$ and $510 \mathrm{~nm}$. Mode of operation $=$ scope. Integration period $=19$, ave $=1$, boxcar $=0$. Wash cuvette 3 times w/borate buffer, fill w/borate and insert, and w/spec set to 
"scope" click on "reference" and check that peak is within the frame, and "store". Cover hole, click on "dark", make sure it's a straight line, and "store". Go to mode of operation, "absorbance", and "scan". This should be close to zero.

F. Bring up Excel and ss.

G. Turn on water bath at approx. $80 \mathrm{~min}$, so that it is at $33^{\circ} \mathrm{C}$ when ferrate is added.

H. Slowly add $5 \mathrm{~g} \mathrm{FeCl}_{3}$ to reactor. Set $\mathrm{t}=0$.

I. Every $10 \mathrm{~min}$, add 3 drops ferrate to $50 \mathrm{mls}$ boric acid. Stir. Weigh before and after and enter difference into ss to determine conversion yield.

Maximum is achieved at $>80 \%$ or over $26 \mathrm{~g} / \mathrm{l}$ of ferrate.

J. Use ss to calculate necessary volumes for experiment.

K. Clean all glassware with $50 \% \mathrm{HCl}$ and reactor $\mathrm{w} / 10 \% \mathrm{HCl}$. Rinse thoroughly $\mathrm{w} / \mathrm{diH}_{2} \mathrm{O}$

\section{A.1.3 Experimental Procedure for HPC}

A. Use working solution (WS) of E.Coli, or other organism, incubated in 4:1

IO:NB for 3-5 days at room temp w/gentle shaking. Record $\mathrm{pH}$ and

FAU/NTU of WS on day of expt.

B. Prepare appropriate plate controls: open/hood, open/ctr, closed/hood, DB, IO.

C. Determine appropriate dilutions of WS for TC and HPC.

D. Apply ferrate per experimental. design, typically $5 \mathrm{mg} / 1$ final concentration in $200 \mathrm{mls}$. Ensure that all mixtures are being adequately stirred. 
E. At appropriate times and concentrations, stop reaction by reducing ferrate with sodium thiosulfate.

F. Make serial dilutions w/dilution buffer. Plate onto R2A agar plates at appropriate dilutions.

G. Allow plates to dry for $10-15$ minutes. Invert and incubate at $26^{\circ} \mathrm{C}$ for 3-7 days.

\section{A.1.4 Quantification of HPC}

A. Count all colonies.

B. Optimum colony counts are 30-300. Less than 30 is statistically unreliable, and greater than 300 results in crowding, which inhibits growth.

C. Multiply by dilution factor.

D. Note that final numbers are expressed as $\mathrm{cfu} / \mathrm{ml}$. Since $0.1 \mathrm{ml}$ of sample is typically plated, this counts as a dilution and must be included in the final calculation.

\section{A.1.5 Experimental Procedure and Quantification for Quanti-Trays/TC (total coliform)/EC (E. coli)}

A. Salt water specimens must be diluted at least 1:10. To ensure that the sample is quenched immediately, have the sodium thiosulfate pellet already dissolved in an amount of sterile water appropriate for the dilution. 
B. $100 \mathrm{mls}$ of diluted sample are mixed with one pack of substrate reagent in a sterile vessel, which is then capped and shaken till substrate dissolves.

Colilert-18 substrate is used for K. pneumoniae and E. coli; Enterolert is used for Enterococci.

C. This mixture is poured into a Quant-Tray and sealed in the sealer.

D. The trays are incubated at $35^{\circ} \mathrm{C}$ for 18 hours (Colilert-18) or $41^{\circ} \mathrm{C}$ for 24 hours (Enterolert).

E. Results are read as follows for Colilert-18:

Colorless or very lightly yellow $=$ negative

Clearly yellow $=$ positive

E. coli will also fluoresce under uv light.

F. Results are read as follows for Enterolert under uv light:

Colorless $=$ negative

Clearly fluorescent $=$ positive

G. The number of positive small and large wells is compared to the chart to determine most probable number (MPN).

H. This gives the MPN in the $100 \mathrm{ml}$ sample. Divide by 100 to obtain MPN/ml, and multiply by any appropriate dilutions.

\section{A.1.6 Sterile Technique-A Few Notes}

The idea is to prevent any contamination of samples and procedures. Therefore:

- Use sterile gloves.

- Wipe down surfaces with disinfectant. 
- Perform testing in biological safety cabinet (BSC).

- Flame vessel (e.g. bottle) openings before pouring.

- Get all reagents and equipment ready in BSC before beginning procedure.

- Do not touch agar or liquids. 


\section{A.2 Optimization of Experimental Procedure}

\section{A.2.1 Effect of Stirring or Vortexing}

\section{A.2.1.1 Effect of Stirring}

Summary: The effect of stirring on disinfection effectiveness was investigated by treating aliquots of a suspension of K. pneumoniae in IO, in glass flasks on a stir plate, with $2 \mathrm{mg} / \mathrm{l}$ ferrate for three conditions: no stirring (NS), moderate stirring (MS, low speed on stir plate), or vigorous stirring (VS, high speed on stir plate, such that a vortex was apparent). Reaction aliquots were quenched at 5 and 15 mins, and K. pneumoniae was quantified by HPC. Figure A-1 summarizes the results, which indicate that stirring markedly increases the log reductions. Vigorous stirring is recommended for faster, greater $\log$ reductions.

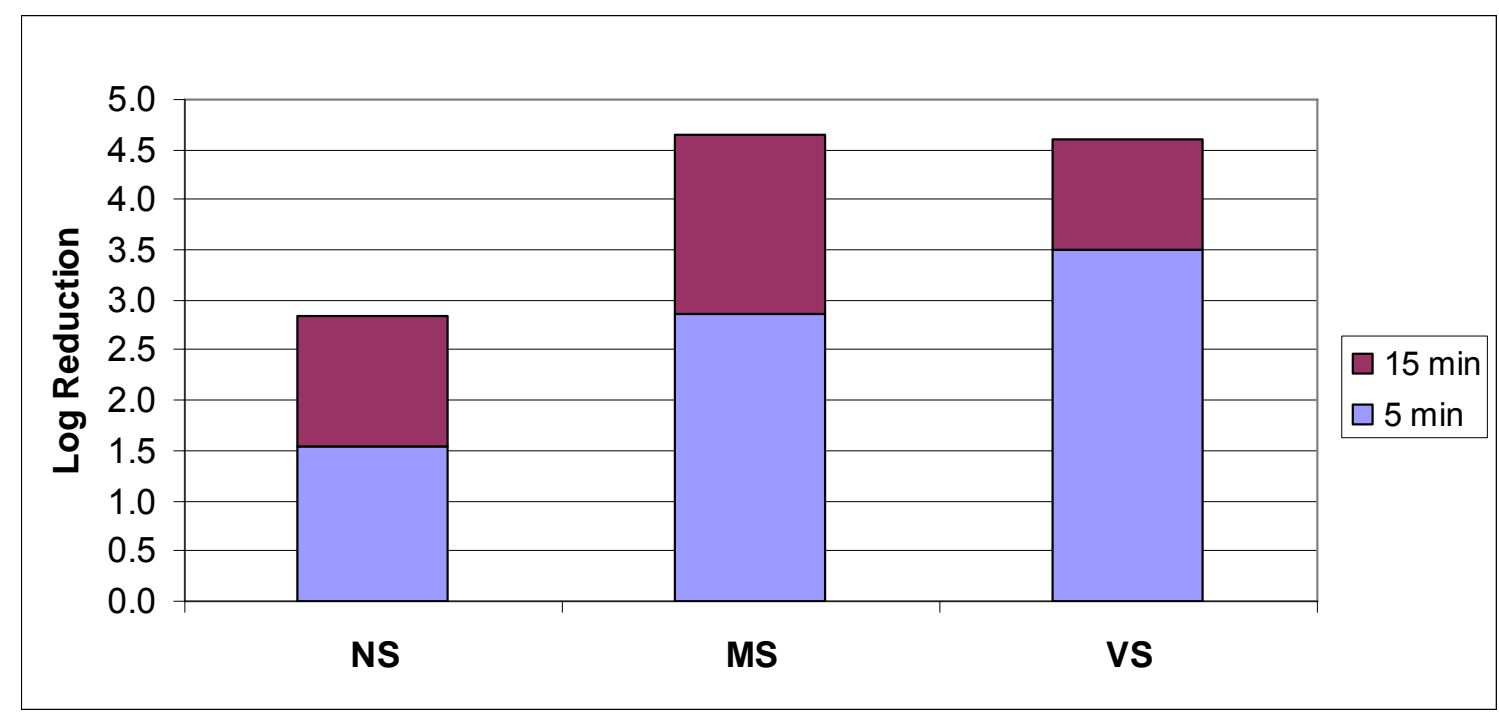

Figure A-1: Effect of Stirring on Ferrate Effectiveness on K. pneumoniae Mortality. 


\section{A.2.1.2 Effect of Vortexing}

Summary: The effect of vortexing on disinfection effectiveness was investigated by treating aliquots of a suspension of $E$. coli in IO in 50-ml disposable centrifuge tubes with 0.75-4 mg/l ferrate for two conditions: normal preparation (inverting tube after ferrate treatment and immediately prior to sampling) and vigorous vortexing (vortexing on high setting after ferrate treatment and immediately prior to each sampling event). Reaction aliquots were quenched at various times, and E. coli was quantified by the Quanti-Tray method. Figure A-2 summarizes the results, which indicate that vortexing markedly increased the log reductions. Vortexing is recommended for faster, greater log reductions.

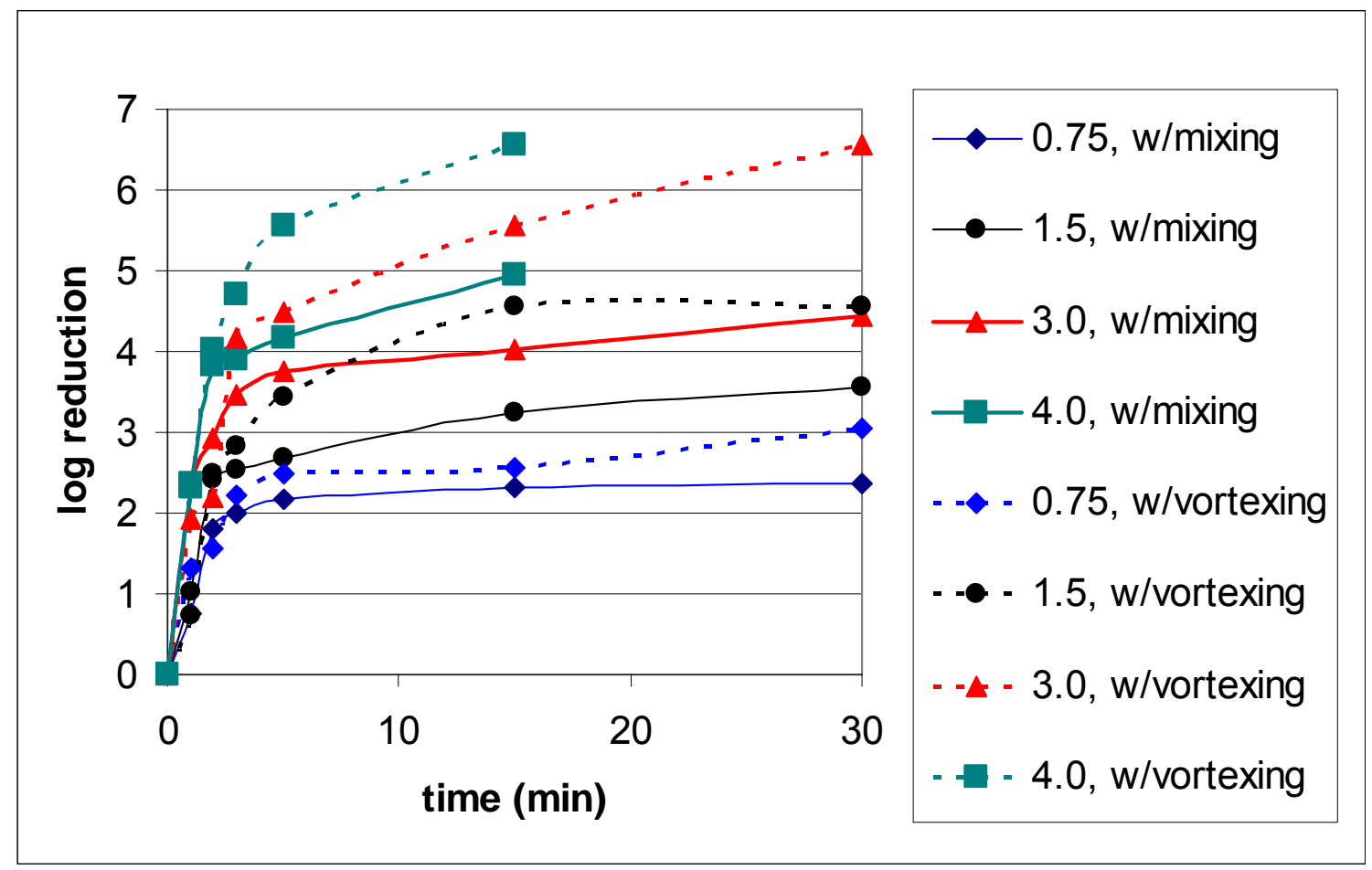

Figure A-2: Effect of Vortexing on Ferrate Effectiveness on E. coli Mortality. 


\section{A.2.2 Effect of Washing of Bacterial Suspension}

Summary: The effect of washing to remove NB on disinfection effectiveness was investigated by spinning a suspension of $E$. coli in 5:1 IO:NB once, resuspending an aliquot in IO ("1X Wash", and re-spinning an aliquot and resuspending an aliquot in IO (“2X Wash”). This was repeated one more time (“3X Wash”). These aliquots were then treated with $0.5 \mathrm{mg} / \mathrm{l}$ ferrate, and reaction aliquots were quenched at $5 \mathrm{~min}$. E. coli was quantified by the Quanti-Tray method, and compared with the starting bacterial concentration $\left(\mathrm{N}_{0}\right)$ for each of the three conditions. Figure A-3 summarizes the results, which indicate that washing repeatedly increased the log reductions. It should be noted that $\mathrm{N}_{0}$ was not the same for these three conditions, but had a fairly small range of $3.2 \mathrm{x}$ $10^{5}-2.3 \times 10^{6}$ organisms $/ \mathrm{ml}$, and there is about a $2 \log$ increase. Washing at least two times is recommended for greater log reductions.

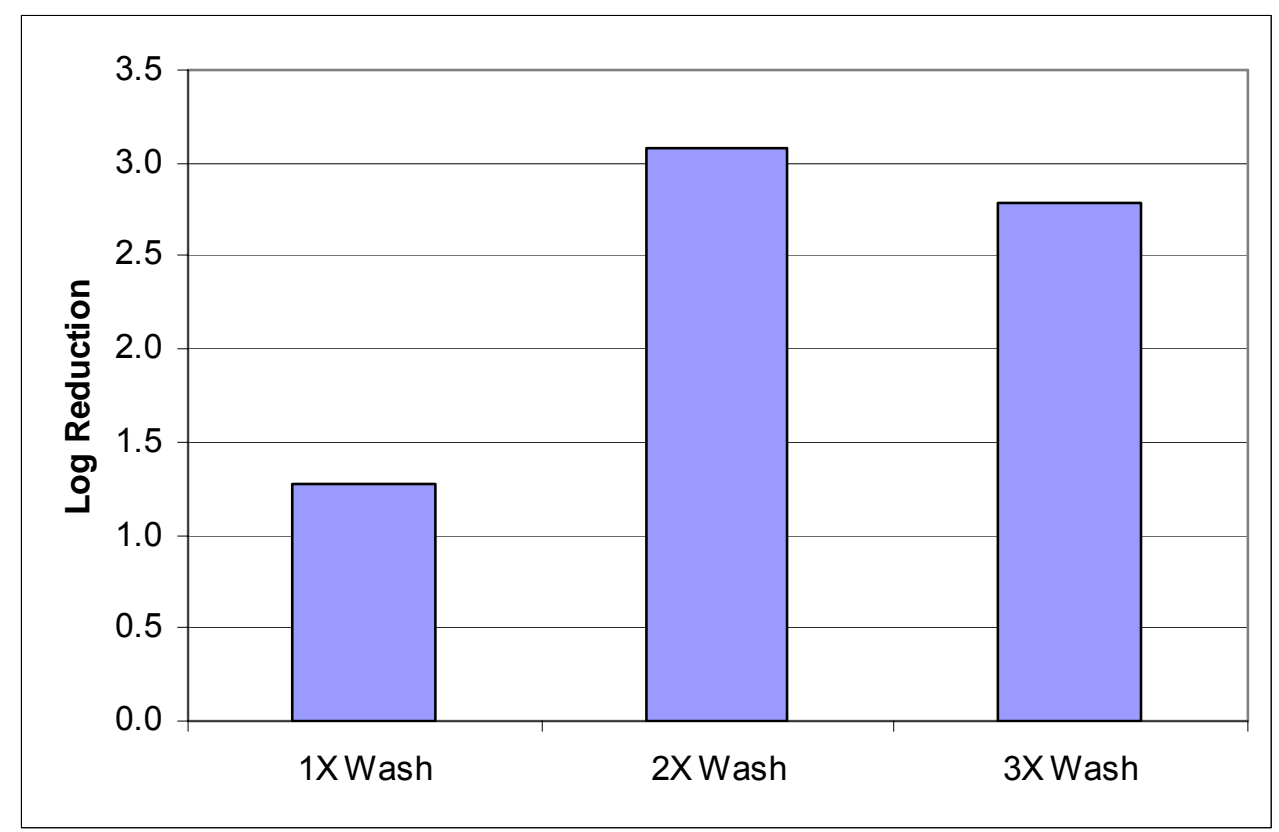

Figure A-3: Effect of Washing on E. coli Mortality by $0.5 \mathrm{mg} / \mathrm{l}$ Ferrate. 


\section{A.2.3 Effect of Delay in_Processing}

Summary: Because large experiments with many stopped reactions at various times and dosages required a delay in processing, this experiment investigated whether this delay would impact results. The effect of delay was investigated by performing a small dosage-response experiment with two dosages and several contact times done in duplicate. The reactions were stopped at the appropriate times and dilutions by adding aliquots to thiosulfate in solution in 100-ml Coliform Test Vial, as described in the Methods section of Chapter 3. Samples were then either processed as quickly as possible ("Immed.") or after a 3-hr delay ("Wait"). Results are graphed in Figure A-4 and indicate that a delay in process would not adversely affect results.

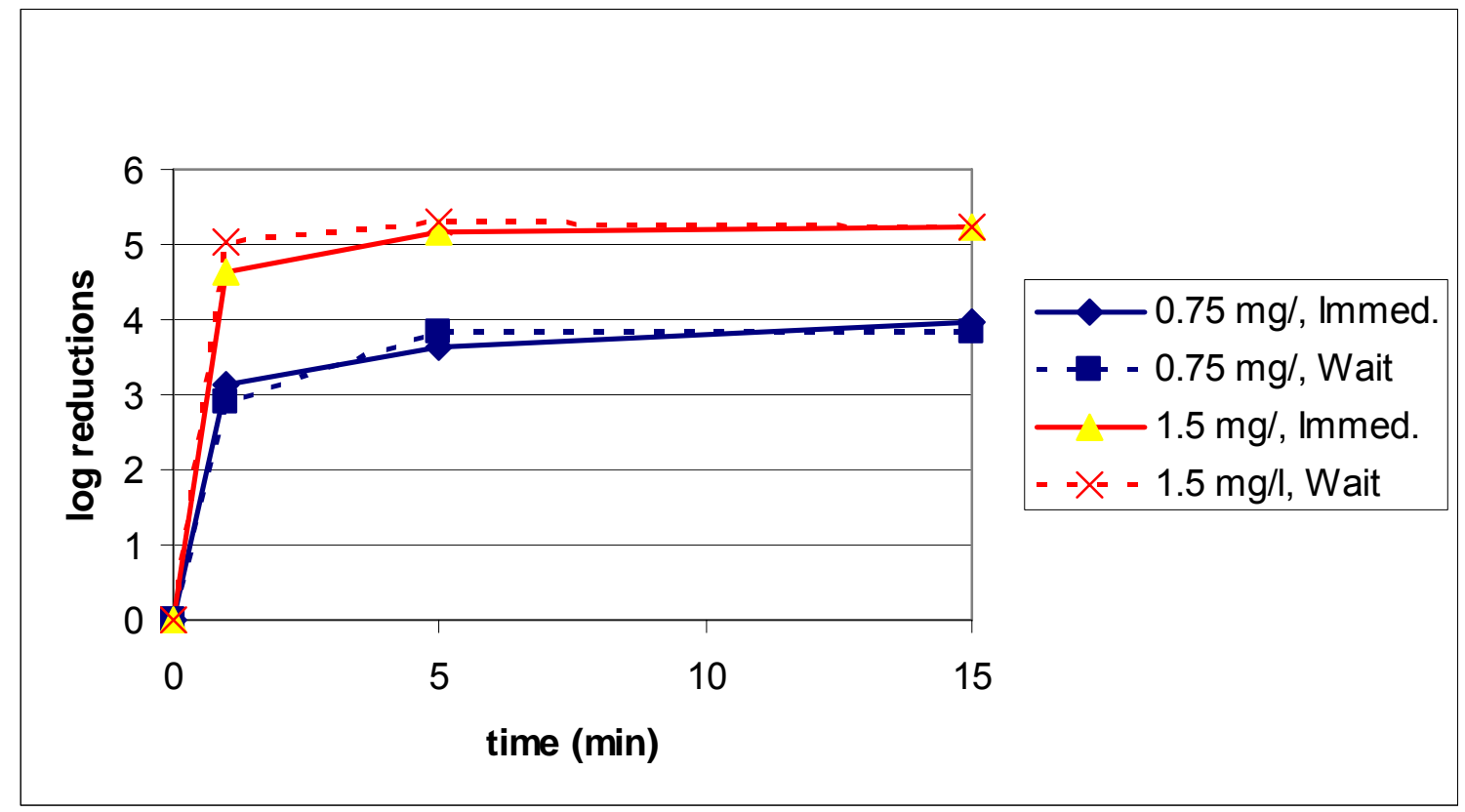

Figure A-4: Effect of Delay in Processing on E. coli Log Reductions. 
APPENDIX B: SUMMARY GRAPHS OF DOSE RESPONSE CURVES FOR TEST ORGANISMS TO FERRATE DISINFECTION 
Each graph represents means and SDs of four experiments.

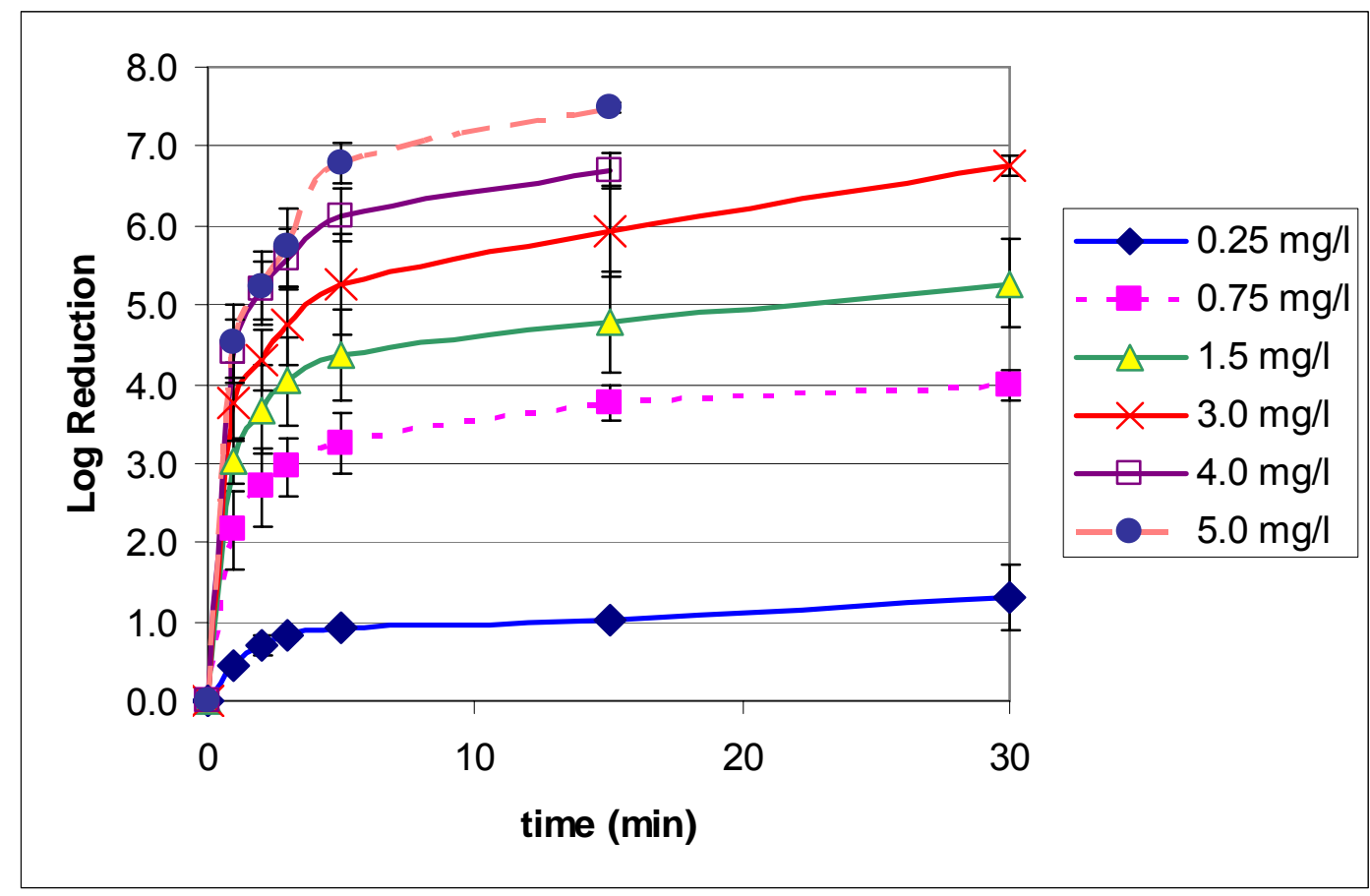

Figure B-1: Summary of Dose Response Curves for $E$. coli. 


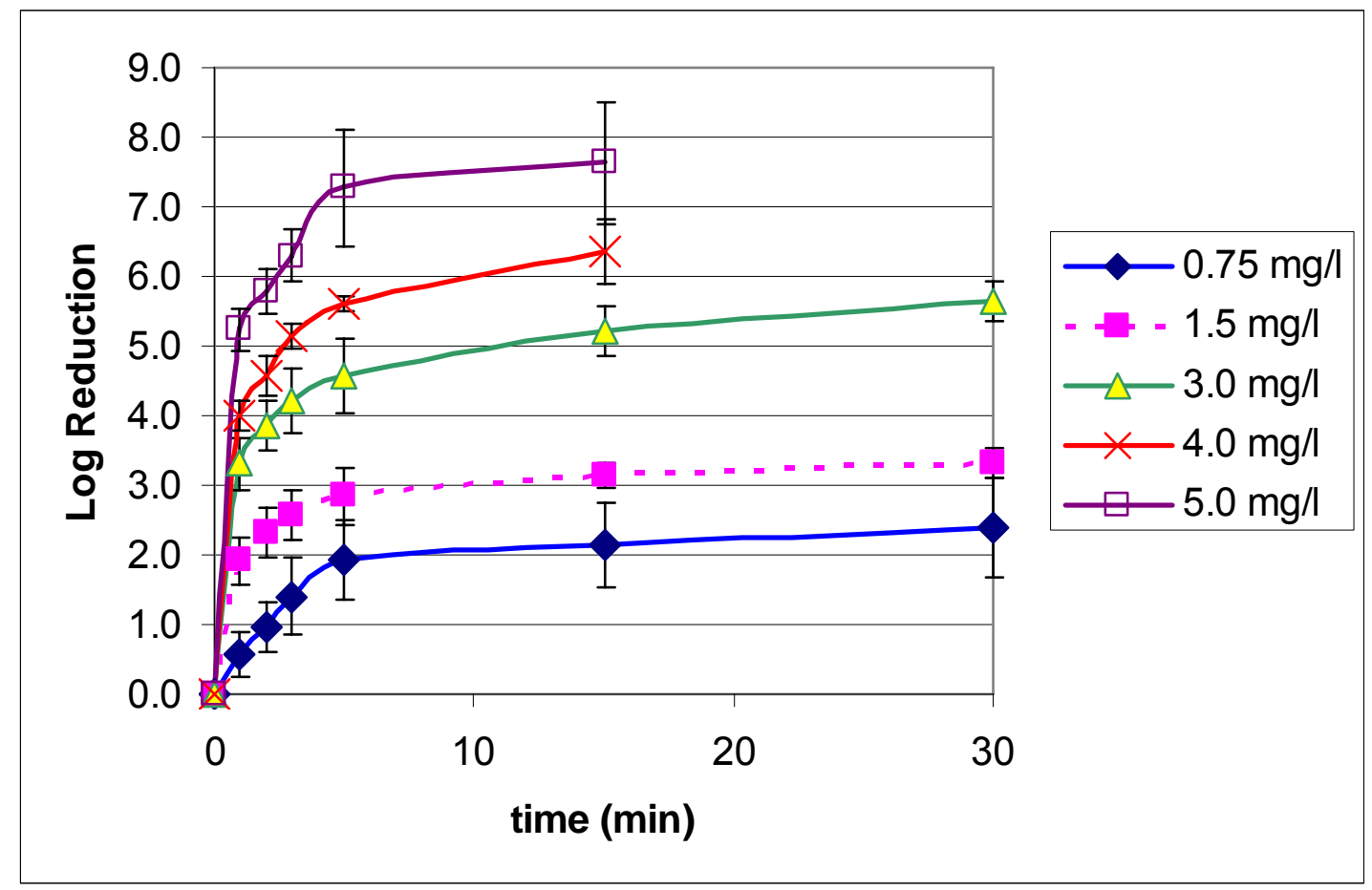

Figure B-2: Summary of Dose Response Curves for K. pneumoniae.

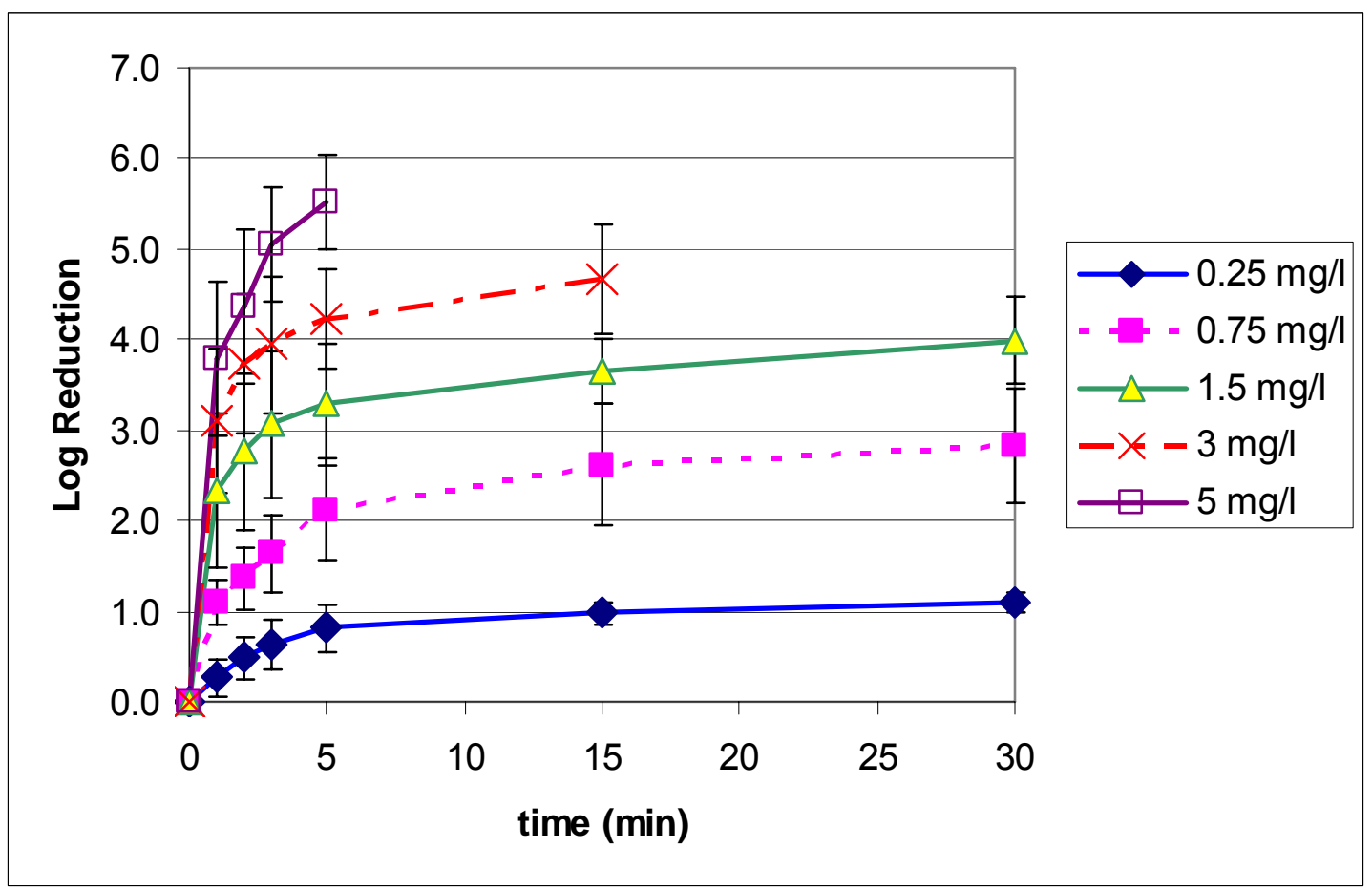

Figure B-3: Summary of Dose Response Curve for Enterococci. 


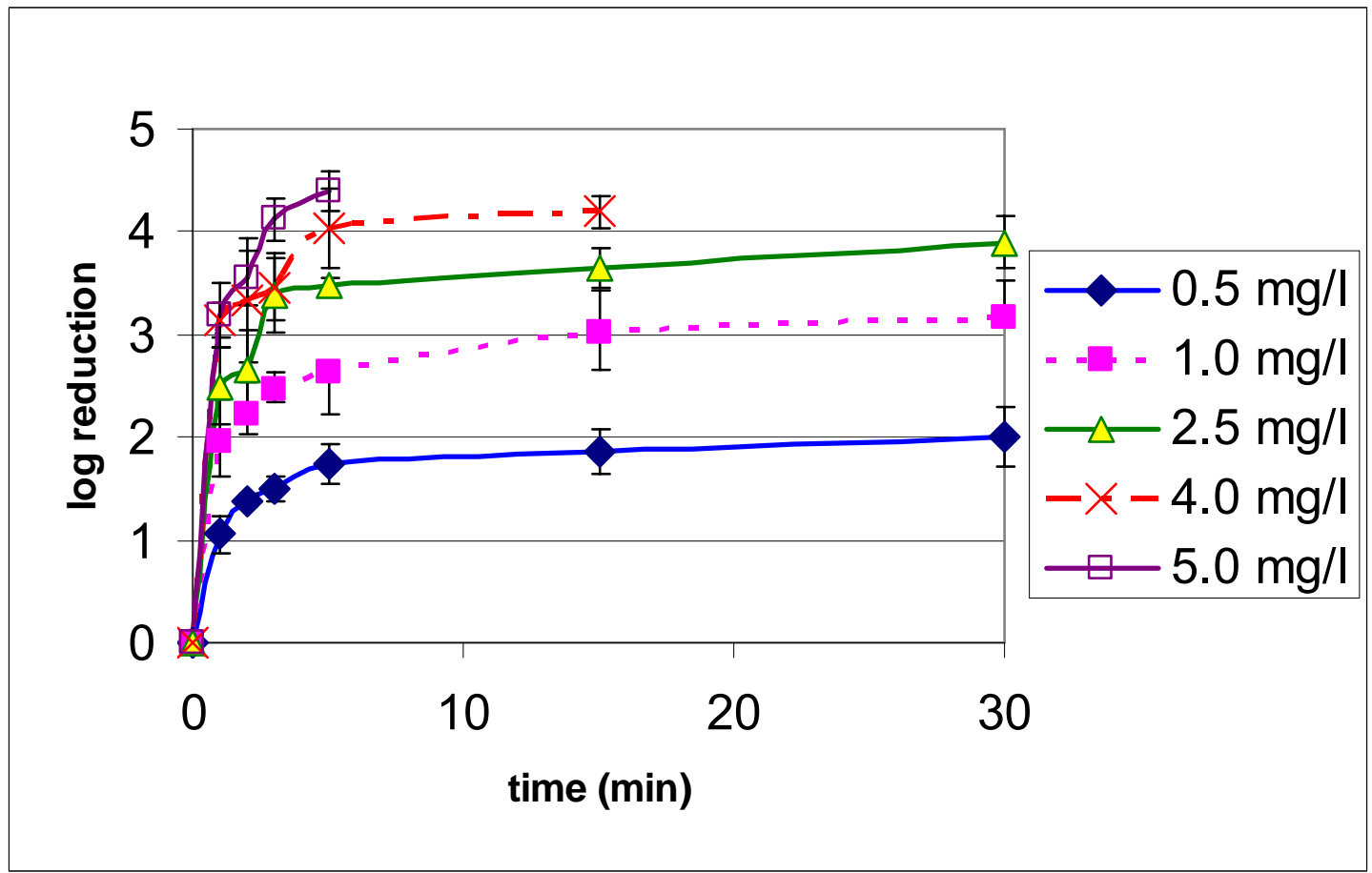

Figure B-4: Summary of Dose Response Curves for V. cholerae. 


\section{APPENDIX C: SAMPLE CALCULATIONS OF KINETIC MODEL CONSTANTS AND PH AND SALINITY EFFECTS}




\section{C.1 Calculations for Chick-Watson and Hom's Coefficients}

The following are the series of calculations conducted to obtain the Chick-Watson and Hom's coefficients for one experiment, in this case for E. coli, experiment \# 79. These calculations were conducted for each of four dosage-response experiments for each of the four organisms. Please see Appendix E for raw data, or spreadsheets for all experiments are available upon request.

1. Quanti-Tray wells were read and tabulated per the procedure in Appendix A for each dosage and time. For example, in this experiment, for $0.25 \mathrm{mg} / \mathrm{l}$ ferrate at one min., two dilutions were done, $10^{3}$ and $10^{6}$. For the lower dilution, all 49 large and 48 small wells were positive, which according to the MPN table results in a value of $>2419.6$. For the $10^{6}$ dilution, 45 large and 15 small wells were positive, which corresponds to a value of 157.6 organisms per $100 \mathrm{mls}$ of sample. This value is used, since the $10^{3}$ dilution value is outside the linearity of the test procedure. It is then multiplied by the dilution and divided by 100 to obtain organisms $(\mathrm{MPN})$ per ml, such that $\left(157.6 \times 10^{6}\right) / 100=157.6 \times 10^{4}$ organisms or MPN/ml. Please note that $V$. cholerae was done by plate method, so colonies on plates were instead counted, in duplicate for each dilution, to produce CFU/ml values. All other calculations were the same. Figure C-1 shows the graph of results from these readings and calculations, for experiment $\# 79$. 


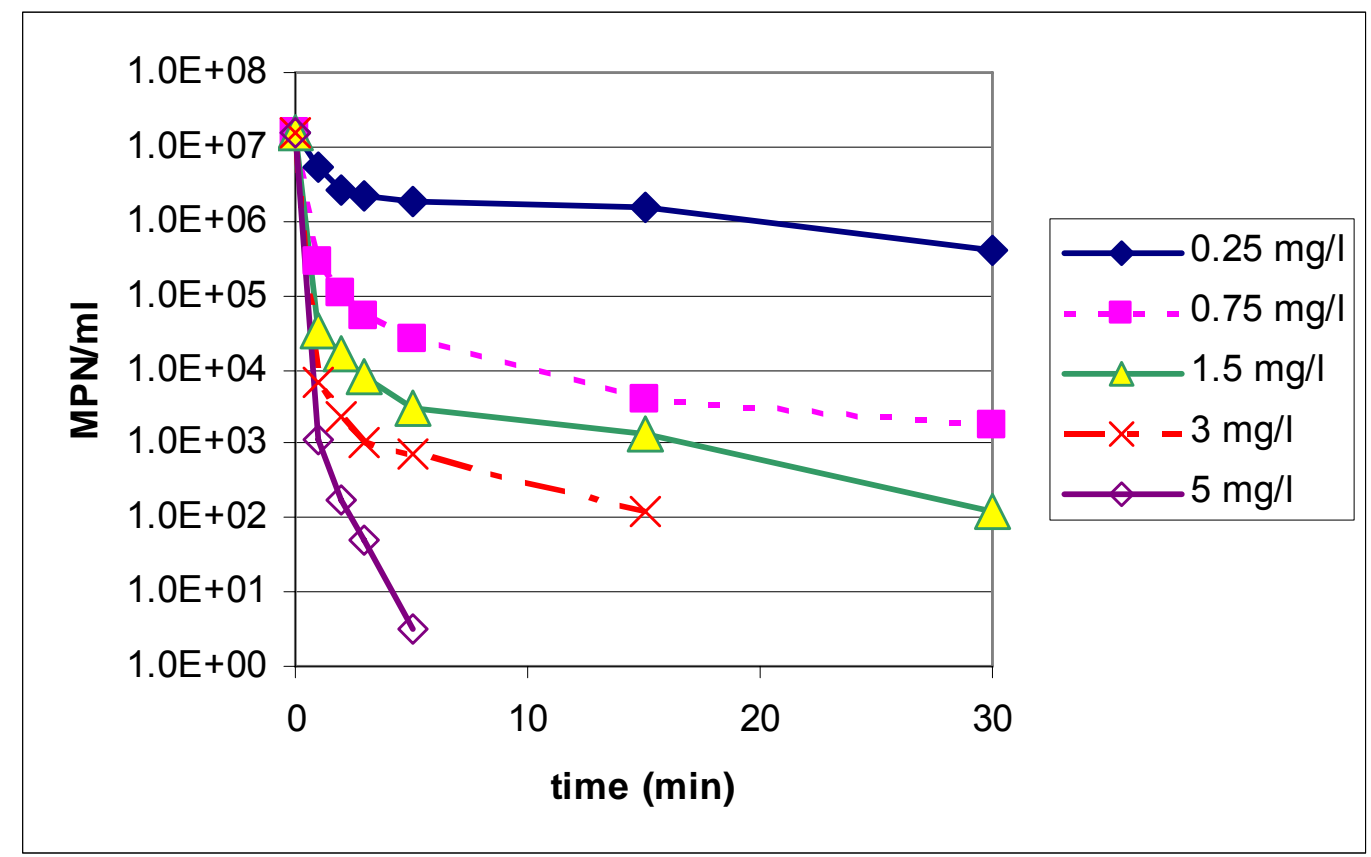

Figure C-1: Dosage-Response Curve for Sample Calculation.

2. The starting bacterial concentration $\left(\mathrm{N}_{0}\right.$, which was calculated by the same procedure) was then divided by the value for each dosage and time $\left(\mathrm{N}_{t}\right)$ and the $\log$ of this is taken to obtain the log reduction for each dosage and time, as shown in Figure C-2.

3. To calculate the Chick-Watson constants, the negative natural $\log$ of $\mathrm{N}_{\mathrm{t}} / \mathrm{N}_{0}$ vs. contact time was graphed log-log, as shown in Figure C-3, per the method of Metcalf \& Eddy (2003). Trend lines were included for ease of reading. 


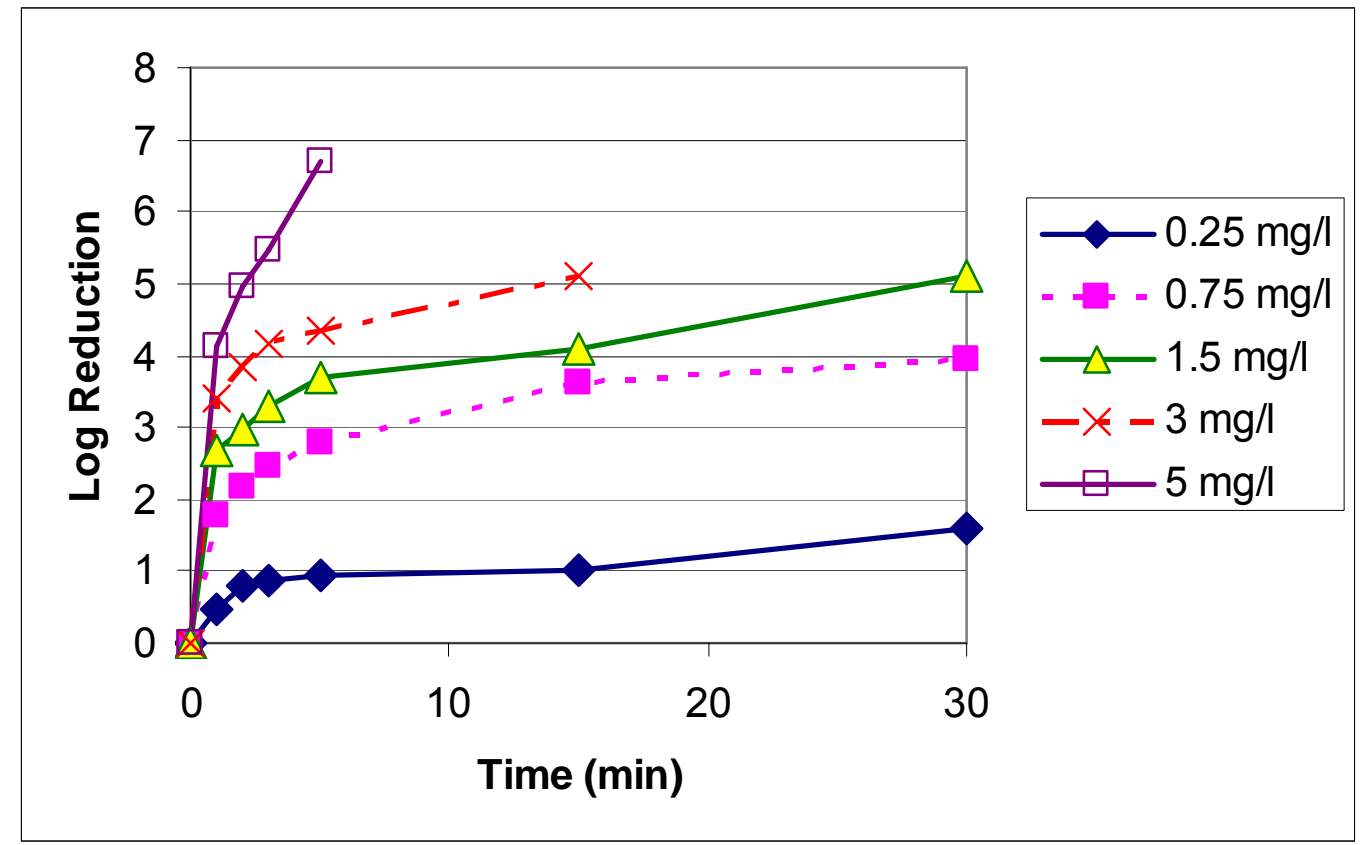

Figure C-2: Log Reduction Graph for Sample Calculation.

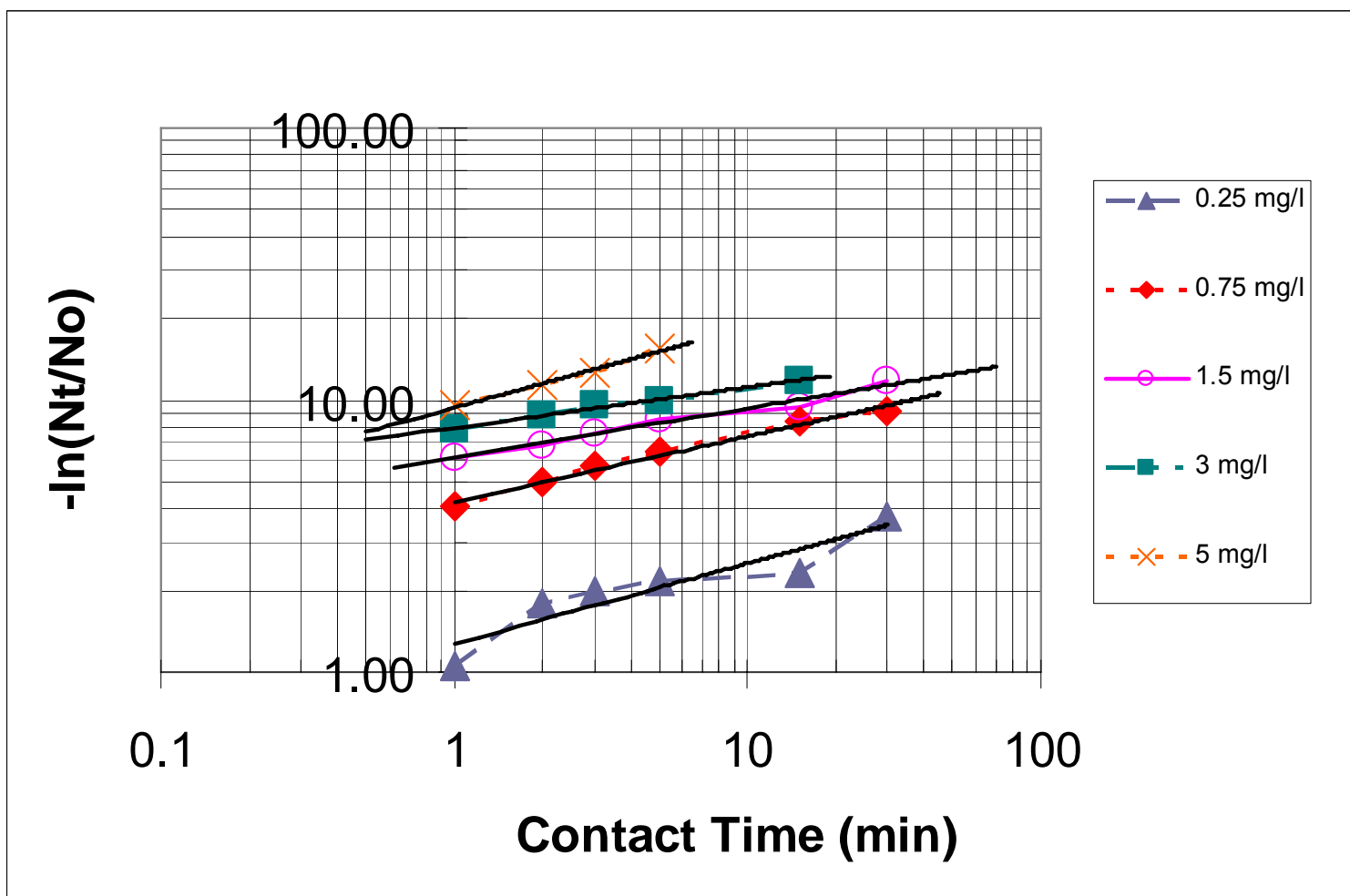

Figure C-3: Chick-Watson Analysis for Sample Calculation: Step 1 
4. For a 4-log removal, this corresponds with $\mathrm{N}_{\mathrm{t}} / \mathrm{N}_{0}=0.0001$, so $-\ln \left(\mathrm{N}_{\mathrm{t}} / \mathrm{N}_{0}\right)=9.2$.

Thus, for each dosage, the contact time needed to achieve this log reduction was determined from Figure 19, as shown in Table C-1.

\section{Table C-1: Contact Times Needed \\ for Each Dosage (Part 2 of \\ Chick-Watson Analysis)}

\begin{tabular}{|r|r|}
\hline $\begin{array}{r}\text { Time to } \\
99.99 \% \text { Kill } \\
(\mathrm{min})\end{array}$ & $\begin{array}{r}\text { Ferrate } \\
\text { Dosage } \\
(\mathrm{mg} / \mathrm{l})\end{array}$ \\
\hline 28 & 0.75 \\
\hline 11 & 1.5 \\
\hline 3 & 3 \\
\hline 1 & 5 \\
\hline
\end{tabular}

5. This was then plotted log-log, as shown in Figure C-4. A trend line was again included for ease of interpretation.

6. From this, the Chick-Watson $n$ coefficient is equal to the negative of the inverse of the slope. The y-intercept was estimated from the graph (in this case as 5), and $\mathrm{k}$ is then calculated from the equation:

$$
\mathrm{k}=-\ln \left(\mathrm{N}_{\mathrm{t}} / \mathrm{N}_{0}\right) / \exp ^{(\mathrm{n} \ln (\mathrm{y}-\mathrm{int}))}
$$

Since the slope in this case is -0.57 , then $n=1.76$. Then, since $\mathrm{N}_{\mathrm{t}} / \mathrm{N}_{0}=0.0001$ for a 4- $\log$ reduction, $\mathrm{k}=0.55$. This was done for each experiment for each organism, generating average $\mathrm{n}$ and $\mathrm{k}$ values. 


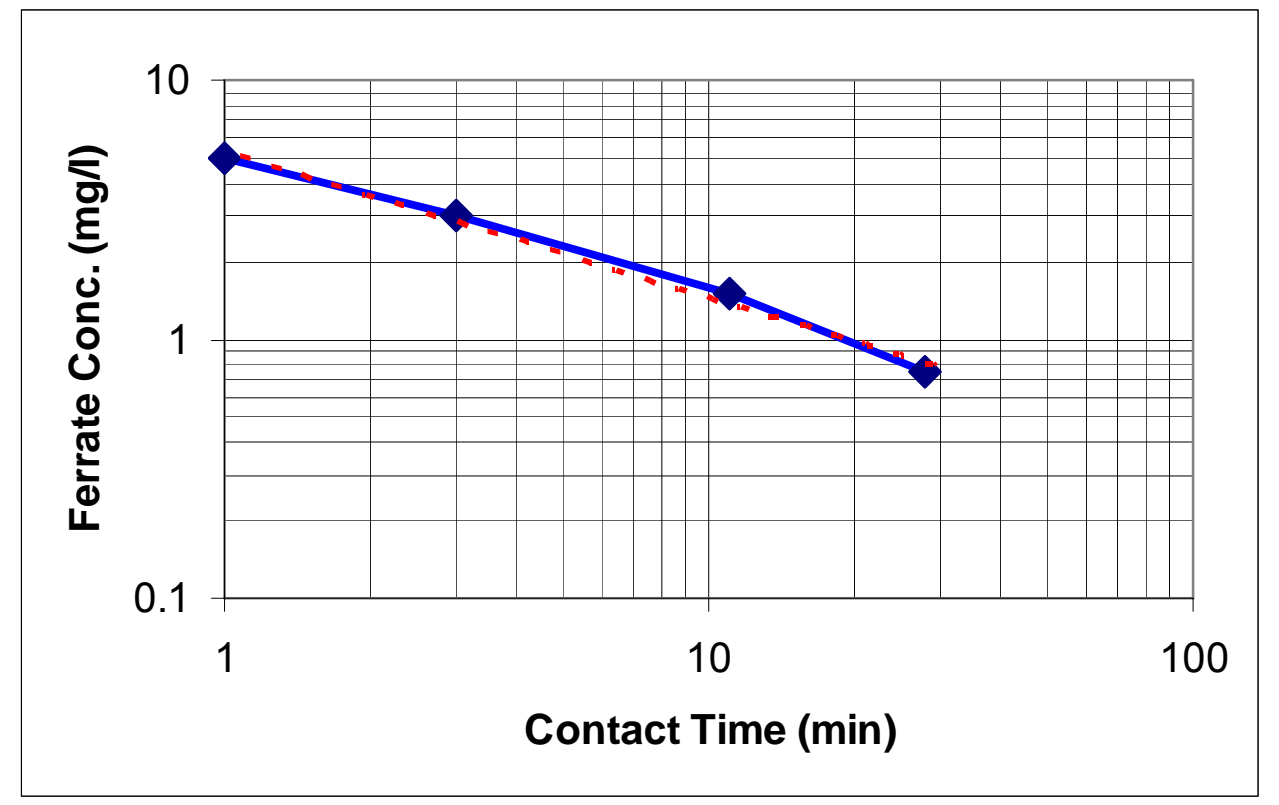

Figure C-4: Part 2 of Chick-Watson Analysis for Sample Calculation (4-log reduction).

7. To generate Hom's coefficients, according to the method of the American Water Works Association (1999), three columns of values were generated for each time (t) and dosage (concentration, $C)$ of ferrate: $\ln (\mathrm{t}), \ln (\mathrm{C})$, and $\ln \left(-\ln \left(\mathrm{N}_{\mathrm{t}} / \mathrm{N}_{0}\right)\right)$.

These were then entered into an SPSS input file, and a linear regression was run with $\ln (\mathrm{t})$ and $\ln (\mathrm{C})$ as independent variables and $\ln \left(-\ln \left(\mathrm{N}_{\mathrm{t}} / \mathrm{N}_{0}\right)\right)$ as the dependent variable. From this, the coefficient for $\ln (\mathrm{t})=\mathrm{m}$, the coefficient for $\ln (\mathrm{C})=\mathrm{n}$, and $\exp ^{\text {(coeff. for consant) }}=\mathrm{k}$. For experiment $\# 79$, Hom's $\mathrm{m}=0.236, \mathrm{n}=0.619$, and $\mathrm{k}=$ 3.963. Means and SDs were calculated for the four experiments.

8. Since the Chick-Watson law states that $\ln \left(\mathrm{N}_{\mathrm{t}} / \mathrm{N}_{0}\right)=-\mathrm{k}^{\prime} \mathrm{C}^{\mathrm{n}} \mathrm{N}_{\mathrm{t}}$, actual vs. predicted values were compared by graphing $\ln \left(\mathrm{N}_{\mathrm{t}} / \mathrm{N}_{0}\right)$ (actual, or experimental) against $-\mathrm{k}^{\prime} \mathrm{C}^{\mathrm{n}} \mathrm{N}_{\mathrm{t}}$ (predicted, from the calculated coefficients), as shown in Figure C-5. The correlation coefficient, R, was calculated by Excel. 


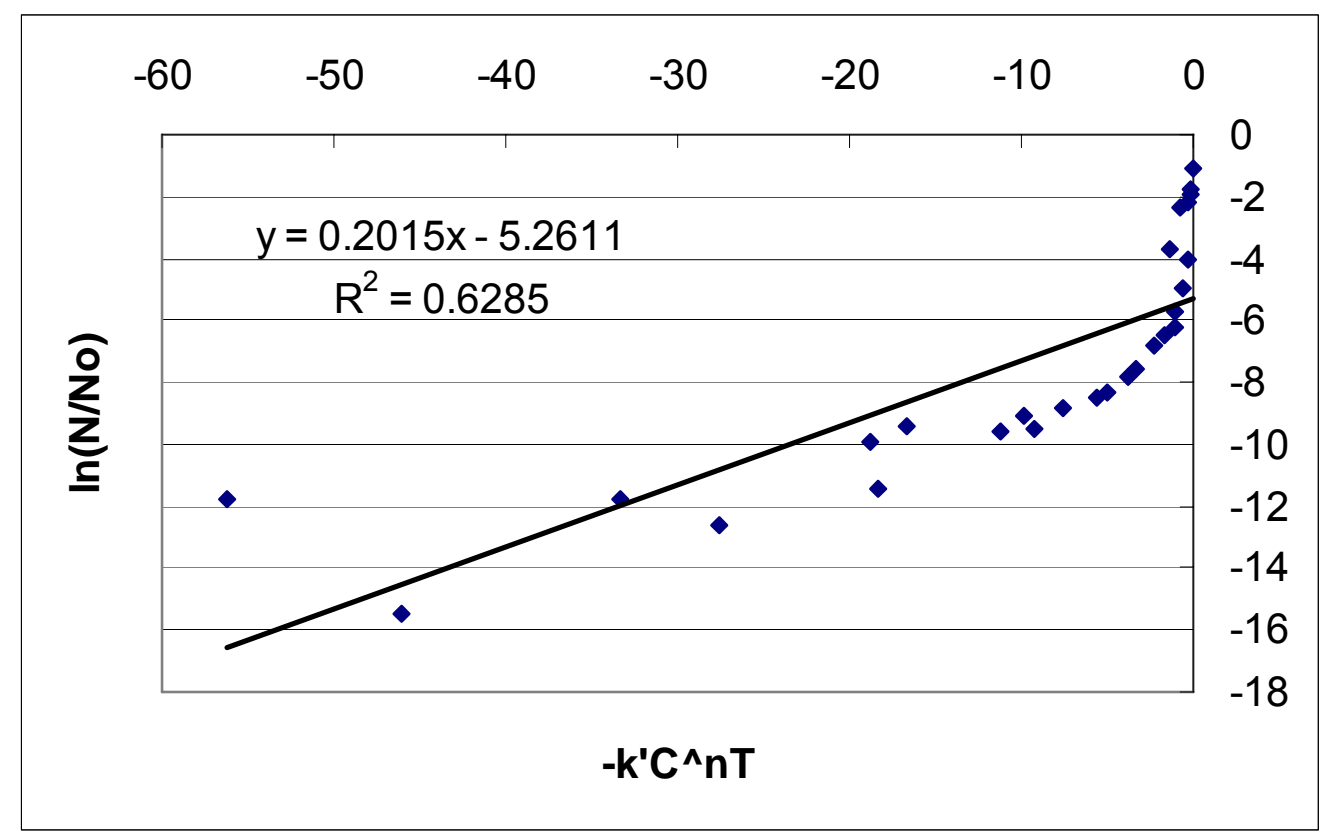

Figure C-5: Chick-Watson Model vs. Actual Data for Sample Calculation.

9. Likewise, the Hom's model states that $\ln \left(\mathrm{N}_{\mathrm{t}} / \mathrm{N}_{0}\right)$ (actual) $=\mathrm{k}^{\prime} \mathrm{C}^{\mathrm{n}} \mathrm{t}^{\mathrm{m}}$ (predicted), so, these were graphed, as shown in Figure C-6, and R was calculated in Excel.

10. Means and SDs for R values for both models were generated for each organism. 


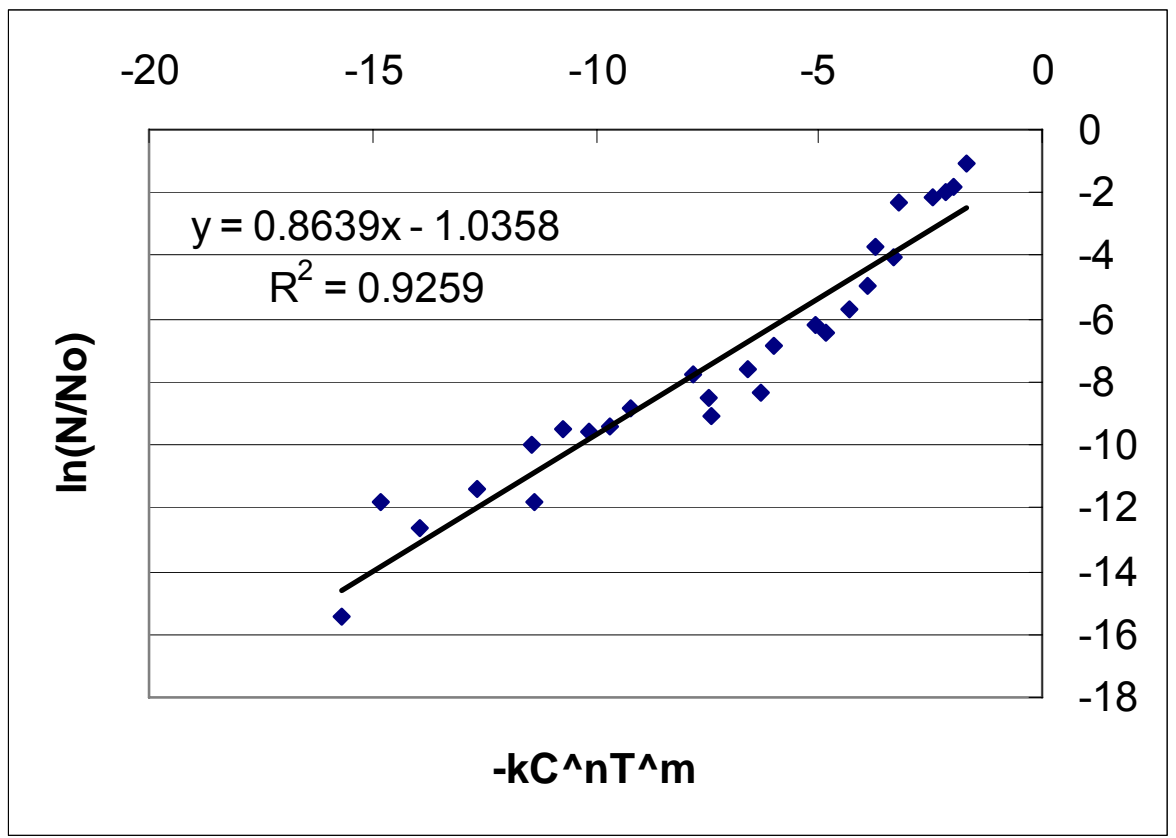

Figure C-6: Hom's Model vs. Actual Data for Sample Calculation. 


\section{C.2 Calculations for Oxidant Demand Coefficients}

The oxidant demand equations were applied to the same dosage-response experiments used to generate the Chick-Watson and Hom's coefficients. However, since coefficients must be determined for separate time points, the four experiments for each organism were combined in order to generate enough data points.

1. $\mathrm{N}_{\mathrm{t}} / \mathrm{N}_{0}$ was calculated, as in section C.1, for each concentration, and this was done for each time. Because of the closeness of time points, the rest of the analysis was done for $1,5,15$, and 30 mins only.

2. $\log (C)$ and $-\log \left(\mathrm{N}_{\mathrm{t}} / \mathrm{N}_{0}\right)$ were calculated and graphed. Linear regression was performed to obtain slope, intercept, and variance $\left(\mathrm{R}^{2}\right)$. Figure $\mathrm{C}-7$ shows the resultant graph and equation for $K$. pneumoniae at $\mathrm{t}=1 \mathrm{~min}$.

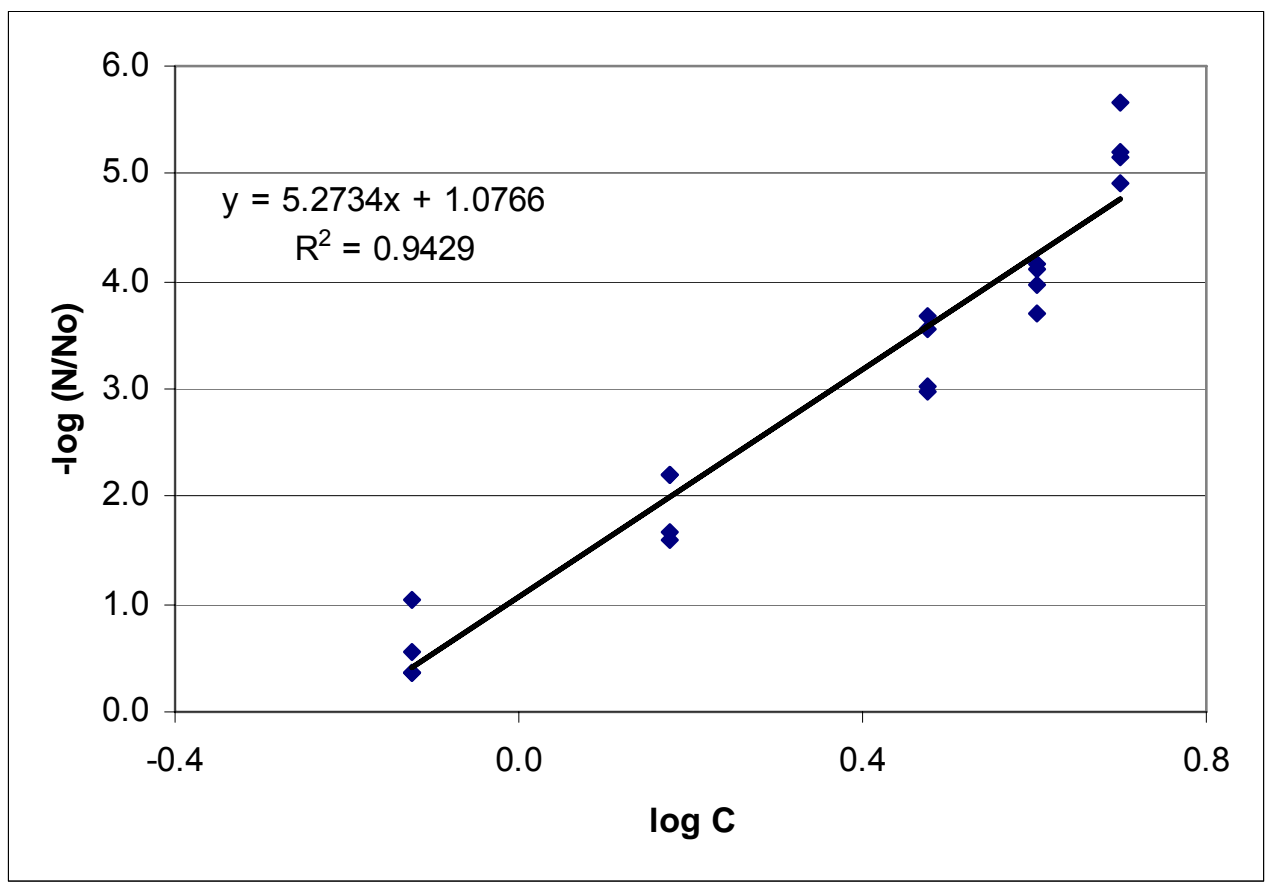

Figure C-7: Graph for K. pneumoniae to Obtain Oxidant Demand Coefficients at 1 min. 
3. The correlation coefficient $\mathrm{R}$ was calculated as the square root of the variance.

4. The slope is equal to the b coefficient, and the y-intercept is the d coefficient.

The x-intercept (initial oxidant demand) is solved from the equation for the linear regression, with appropriate conversions from the $\log$ values. I.e. $\mathrm{N}_{\mathrm{t}} / \mathrm{N}_{0}=1$ (to correspond with point where survival begins to decline from unity), so $\log \left(\mathrm{N}_{\mathrm{t}} / \mathrm{N}_{0}\right)=0$, then $\mathrm{x}=(\mathrm{y}-\mathrm{d}) / \mathrm{b}$, and initial oxidant demand $=10^{\mathrm{x}}$.

5. To determine whether the slopes (b coefficient) differed significantly for the different contact times, the equation:

$$
\mathrm{t}=\left(\mathrm{b}_{1}-\mathrm{b}_{1}^{*}\right) /\left(\mathrm{s} / \text { sq.rt. }\left(\mathrm{SS}_{\mathrm{x}}\right)\right)
$$

was used to test the null hypothesis that $\mathrm{b}_{1}-\mathrm{b}_{1}{ }^{*}=0$. In this equation, $\mathrm{SS}_{\mathrm{x}}$ is the sum of squares for $\mathrm{x}$ (where $\mathrm{x}$ is $\log$ of ferrate concentration, $\mathrm{C}$, and $\left.\mathrm{SS}_{\mathrm{x}}=\Sigma\left(\mathrm{x}-\mathrm{x}_{\mathrm{avg}}\right)^{2}\right)$, $b_{1}{ }^{*}$ is a slope other than $b_{1}$, in this case, a slope for a different contact time, and $s$ is the standard error of the regression. This can be calculated as the square root of the mean square error (MSE), which is defined as:

$$
\begin{aligned}
& \mathrm{MSE}=\mathrm{s}^{2}=\left(\mathrm{SS}_{\mathrm{y}}-\mathrm{b}_{1} \mathrm{~S}_{\mathrm{xy}}\right) /(\mathrm{n}-2) \\
& \text { where }: \\
& \mathrm{SS}_{\mathrm{y}}=\Sigma\left(\mathrm{y}-\mathrm{y}_{\mathrm{avg}}\right)^{2} \\
& \mathrm{~S}_{\mathrm{xy}}=\Sigma\left(\mathrm{x}-\mathrm{x}_{\mathrm{avg}}\right)\left(\mathrm{y}-\mathrm{y}_{\mathrm{avg}}\right) \\
& \text { and } \mathrm{n}=\text { number of observations }
\end{aligned}
$$

This is equivalent to the Excel function for the standard error of the regression of $\mathrm{y}$ and $\mathrm{x}$ ("STEYX"). Thus, for the example given in Figure 22 for K. pneumoniae at $1 \mathrm{~min}$, these calculations result in the values given in Table C-2.

6. This was done for all contact times, and the slope of each one was compared with all the others (which becomes $b_{1}{ }^{*}$ in equation 1 ). The degrees of freedom for 
each comparison was calculated as $\mathrm{n}+\mathrm{n}_{1}{ }^{*}-2$ where $\mathrm{n}_{1}{ }^{*}$ is the number of observations for $b_{1}{ }^{*}$. This was used to obtain the null hypothesis $t$ values $\left(t_{\text {crit }}\right)$

Table C-2: Sample Calculations for Oxidant Demand Equation Parameters and Statistics.

\begin{tabular}{|rrrrr|rr|}
\hline $\begin{array}{r}\mathrm{C} \\
(\mathrm{mg} / \mathrm{l})\end{array}$ & $\mathrm{N} / \mathrm{N}_{0}$ & $\log \mathrm{C}$ & $\log \left(\mathrm{N} / \mathrm{N}_{0}\right)$ & $\left(\mathrm{x}-\mathrm{x}_{\text {avg }}\right)^{2}$ & Parameter & Value \\
\hline 0.75 & 0.4433 & -0.12 & 0.35 & 0.241 & $\mathrm{~b}$ & 5.27 \\
1.5 & 0.0213 & 0.18 & 1.67 & 0.036 & $\mathrm{~d}$ & 1.08 \\
3 & 0.0011 & 0.48 & 2.98 & 0.012 & $\mathrm{n}$ & 20 \\
4 & 0.0001 & 0.60 & 4.12 & 0.056 & $\mathrm{R}^{2}$ & 0.94 \\
5 & 0.0000 & 0.70 & 5.65 & 0.111 & $\mathrm{R}$ & 0.97 \\
0.75 & 0.4261 & -0.12 & 0.37 & 0.241 & $\mathrm{x}_{\text {avg }}$ & 0.37 \\
1.5 & 0.0255 & 0.18 & 1.59 & 0.036 & $\mathrm{SS}_{\mathrm{x}}$ & 1.824 \\
3 & 0.0010 & 0.48 & 3.02 & 0.012 & $\mathrm{~S}$ & 0.413 \\
4 & 0.0002 & 0.60 & 3.69 & 0.056 & & \\
5 & 0.0000 & 0.70 & 4.92 & 0.111 & & \\
0.75 & 0.2768 & -0.12 & 0.56 & 0.241 & & \\
1.5 & 0.0063 & 0.18 & 2.20 & 0.036 & & \\
3 & 0.0002 & 0.48 & 3.68 & 0.012 & & \\
4 & 0.0001 & 0.60 & 3.98 & 0.056 & & \\
5 & 0.0000 & 0.70 & 5.19 & 0.111 & & \\
0.75 & 0.0897 & -0.12 & 1.05 & 0.241 & & \\
1.5 & 0.0063 & 0.18 & 2.20 & 0.036 & & \\
3 & 0.0003 & 0.48 & 3.56 & 0.012 & & \\
4 & 0.0001 & 0.60 & 4.16 & 0.056 & & \\
5 & 0.0000 & 0.70 & 5.16 & 0.111 & & \\
\hline
\end{tabular}

from a standard Student's $t$ test table. Plugging these values into equation 1 results in the values given in Table C-3. 
Table C-3: Sample Calculations for Hypothesis Testing of Oxidant Demand Slope Comparisons.

\begin{tabular}{|c|c|c|}
\hline$b^{*}(5 \min )$ & $b^{*}(15 \min )$ & $b^{*}(30 \min )$ \\
\hline 6.06 & 6.51 & 5.55 \\
\hline $\mathrm{df}(5 \mathrm{~min})$ & $\mathrm{df}(15 \mathrm{~min})$ & $\mathrm{df}(30 \mathrm{~min})$ \\
\hline 38 & 38 & 30 \\
\hline tcrit & tcrit & tcrit \\
\hline 2.025 & 2.025 & 2.042 \\
\hline tcalc(vs 5') & tcalc(vs 15') & tcalc(vs 30') \\
\hline-1.816 & -3.062 & -0.636 \\
\hline $\begin{array}{l}\text { Significant at } p= \\
\text { no }=\end{array}$ & 0.05 (alpha $=$ & 5) level? \\
\hline
\end{tabular}

7. This was done for all organisms for the $1,5,15$, and 30 min contact times. 


\section{C.3 Calculations for $\mathrm{pH}$ and Salinity Effects}

1. MPNs at various times and dosages were determined for ferrate-treated and untreated specimens, and the log reduction was calculated relative to the starting bacterial concentration, $\mathrm{N}_{0}$. For example, for the $-1.5 \mathrm{pH}$ condition (please see Section 3.1.2 for procedure outline), two different dilutions $-10^{-1}$ and $10^{-3}-$ were done at $\mathrm{t}=30 \mathrm{~min}$. The MPN/100 $\mathrm{ml}$ for these was 920.8 and 7.5 , respectively, which calculated to 92 and $75 \mathrm{MPN} / \mathrm{ml}\left(\mathrm{N}_{\mathrm{t}}\right)$, respectively, after considering the dilution. If, as in this example, more than one dilution resulted in a value within linearity of the test, then, in general, an average of these, or the value that resulted in the smoothest curve, or the more conservative value was used. The log reduction was then calculated relative to $\mathrm{N}_{0}\left(\log \left(\mathrm{N}_{0} / \mathrm{N}_{\mathrm{t}}\right)\right.$. The same was done for the untreated specimen at this time point. Thus, for the example, the log reduction for the treated specimen was 5.72 and 0.09 for the untreated specimen, resulting in a delta $\log$ reduction of 5.63 .

2. The delta log reductions were then tabulated for each condition. For $\mathrm{pH}$, the delta $\log$ reductions for each $\mathrm{pH}$ condition and time point were tabulated for each dosage. For salinity, the delta log reductions for each salinity condition, time point, and dosage were tabulated.

3. These were then entered into S-PLUS 2000 and a fixed effect ANOVA of a multifactorial design was run, using time, dosage, and $\mathrm{pH}$ or salinity as independent variables, and delta $\log$ reduction as the dependent variable.

4. Results are summarized in Appendix D. 
APPENDIX D: SUMMARY OF STATISTICS 
D.1 Summary of Statistics: Chick-Watson and Hom's Coefficients

Table D-1: Means and SDs for Chick-Watson and Hom's Coefficients.

\begin{tabular}{|c|c|c|c|c|c|c|c|c|c|c|}
\hline \multirow[b]{2}{*}{ Organism } & \multirow[b]{2}{*}{ Expt. \# } & \multicolumn{3}{|c|}{$\underline{\mathrm{CW}}$ means and SDs } & \multicolumn{4}{|c|}{ Hom's means and SDS } & \multicolumn{2}{|c|}{ Model vs Actual } \\
\hline & & $\mathrm{n}$ & $k^{\prime}$ & $\mathrm{R}$ & $\mathrm{n}$ & $\mathrm{M}$ & k & $\mathrm{R}$ & Rhom & Rcw \\
\hline \multirow{6}{*}{ E. coli } & 79 & 1.756 & 0.545 & 0.793 & 0.619 & 0.236 & 3.963 & 0.962 & 0.970 & 0.793 \\
\hline & 80 & 1.917 & 0.616 & 0.766 & 0.667 & 0.194 & 4.306 & 0.940 & 0.950 & 0.765 \\
\hline & 92 & 2.545 & 1.394 & 0.822 & 0.291 & 0.150 & 6.896 & 0.973 & 0.965 & 0.822 \\
\hline & 93 & 2.113 & 0.904 & 0.722 & 0.393 & 0.163 & 6.443 & 0.971 & 0.966 & 0.736 \\
\hline & mean & 2.083 & 0.865 & 0.776 & 0.493 & 0.186 & 5.402 & 0.962 & 0.963 & 0.779 \\
\hline & sd & 0.341 & 0.385 & 0.043 & 0.180 & 0.038 & 1.482 & 0.015 & 0.009 & 0.037 \\
\hline \multirow{6}{*}{$\begin{array}{c}K . \\
\text { pneumoniae }\end{array}$} & 86 & 6.939 & 0.004 & 0.566 & 1.025 & 0.229 & 2.257 & 0.973 & 0.970 & 0.606 \\
\hline & 87 & 5.246 & 0.008 & 0.636 & 0.933 & 0.248 & 2.223 & 0.974 & 0.979 & 0.632 \\
\hline & 88 & 4.841 & 0.013 & 0.723 & 0.718 & 0.225 & 3.459 & 0.960 & 0.969 & 0.708 \\
\hline & 89 & 4.529 & 0.025 & 0.746 & 0.696 & 0.185 & 3.796 & 0.980 & 0.980 & 0.721 \\
\hline & mean & 5.389 & 0.013 & 0.668 & 0.843 & 0.222 & 2.934 & 0.972 & 0.975 & 0.667 \\
\hline & $\mathrm{sd}$ & 1.074 & 0.009 & 0.083 & 0.162 & 0.026 & 0.813 & 0.008 & 0.006 & 0.056 \\
\hline \multirow{6}{*}{ Enterococci } & 74 & 2.284 & 0.108 & 0.841 & 0.895 & 0.399 & 1.815 & 0.972 & 0.967 & 0.793 \\
\hline & 75 & 2.737 & 0.057 & 0.805 & 0.627 & 0.247 & 2.795 & 0.984 & 0.948 & 0.765 \\
\hline & 81 & 2.323 & 0.441 & 0.737 & 0.687 & 0.224 & 3.808 & 0.960 & 0.958 & 0.823 \\
\hline & 82 & 2.230 & 0.688 & 0.709 & 0.738 & 0.249 & 3.572 & 0.936 & 0.964 & 0.736 \\
\hline & mean & 2.394 & 0.324 & 0.773 & 0.737 & 0.280 & 2.998 & 0.963 & 0.958 & 0.794 \\
\hline & sd & 0.232 & 0.297 & 0.061 & 0.115 & 0.080 & 0.899 & 0.020 & 0.010 & 0.029 \\
\hline \multirow{6}{*}{ V. cholerae } & 94 & 2.786 & 0.041 & 0.651 & 0.413 & 0.152 & 4.336 & 0.934 & 0.934 & 0.651 \\
\hline & 95 & 3.037 & 0.023 & 0.733 & 0.427 & 0.139 & 4.092 & 0.963 & 0.960 & 0.733 \\
\hline & 96 & 3.404 & 0.012 & 0.713 & 0.413 & 0.168 & 3.626 & 0.931 & 0.931 & 0.713 \\
\hline & 97 & 2.801 & 0.061 & 0.778 & 0.376 & 0.146 & 4.092 & 0.963 & 0.966 & 0.778 \\
\hline & mean & 3.007 & 0.034 & 0.719 & 0.407 & 0.151 & 4.037 & 0.948 & 0.948 & 0.719 \\
\hline & $s d$ & 0.289 & 0.021 & 0.053 & 0.022 & 0.012 & 0.297 & 0.018 & 0.018 & 0.053 \\
\hline
\end{tabular}


D.2 Summary of Statistics: Oxidant Demand Equation Coefficients and Hypothesis Testing

D.2.1 Oxidant Demand Coefficients and Hypothesis Testing for E. coli

\begin{tabular}{|c|c|c|c|c|c|c|c|c|c|c|c|c|c|c|c|}
\hline $\begin{array}{r}\text { time } \\
(\mathrm{min})\end{array}$ & $\mathbf{n}$ & $\mathbf{s}$ & $\mathbf{S S}_{\mathrm{x}}$ & b & d & $\mathbf{R}^{2}$ & $X_{\text {avg }}$ & $\begin{array}{r}b^{*} \\
(1 \mathrm{~min})\end{array}$ & $\begin{array}{r}b^{*} \\
(5 \mathrm{~min})\end{array}$ & $\begin{array}{r}b^{*} \\
(15 \mathrm{~min}) \\
\end{array}$ & $\begin{array}{r}b^{*} \\
\text { (30min) } \\
\end{array}$ & $\begin{array}{r}d f \\
(1 \mathrm{~min})\end{array}$ & $\begin{array}{r}d f \\
(5 \mathrm{~min})\end{array}$ & $\begin{array}{r}d f \\
(15 \mathrm{~min}) \\
\end{array}$ & $\begin{array}{r}d f \\
\text { (30min) }\end{array}$ \\
\hline 1 & 20 & 0.388 & 3.296 & 3.06 & 2.43 & 0.92 & 0.25 & & 4.231 & 4.539 & 4.976 & & 38 & 36 & 30 \\
\hline 5 & 20 & 0.465 & 3.296 & 4.23 & 3.60 & 0.94 & 0.25 & 3.057 & & 4.539 & 4.976 & 38 & & 36 & 30 \\
\hline 15 & 18 & 0.514 & 3.099 & 4.54 & 4.02 & 0.95 & 0.20 & 3.057 & 4.231 & & 4.976 & 36 & 36 & & 28 \\
\hline 30 & 12 & 0.335 & 1.367 & 4.98 & 4.44 & 0.96 & -0.004 & 3.057 & 4.231 & 4.539 & & 30 & 30 & 28 & \\
\hline
\end{tabular}

\begin{tabular}{|c|c|c|c|c|c|c|c|c|c|c|c|}
\hline $\begin{array}{l}t_{\text {calc }} \\
\text { (vs 1') }\end{array}$ & $\begin{array}{l}t_{\text {calc }} \\
\text { (vs 5') }\end{array}$ & $\begin{array}{l}t_{\text {calc }} \\
\text { (vs 15') }\end{array}$ & $\begin{array}{l}t_{\text {calc }} \\
\text { (vs 30') }\end{array}$ & $t_{\text {crit }}$ & $t_{\text {crit }}$ & $t_{\text {crit }}$ & $t_{\text {crit }}$ & \multicolumn{4}{|c|}{$\begin{array}{l}\text { Significant at } p=0.05(\text { alpha }=0.025) \\
\text { level? }\end{array}$} \\
\hline & -4.997 & -5.872 & -8.106 & & 2.025 & 2.03 & 2.042 & & yes & yes & yes \\
\hline 4.997 & & -1.125 & -2.847 & 2.025 & & 2.03 & 2.042 & yes & & no & yes \\
\hline 5.872 & 1.125 & & -1.539 & 2.03 & 2.03 & & 2.048 & yes & no & & no \\
\hline 8.106 & 2.847 & 1.539 & & 2.042 & 2.042 & 2.048 & & yes & yes & no & \\
\hline
\end{tabular}


D.2.2 Oxidant Demand Coefficients and Hypothesis Testing for K. pneumoniae

\begin{tabular}{|c|c|c|c|c|c|c|c|c|c|c|c|c|c|c|c|}
\hline $\begin{array}{r}\text { time } \\
(\min )\end{array}$ & $\mathbf{n}$ & $\mathbf{s}$ & $\mathbf{S S}_{\mathrm{x}}$ & b & d & $\mathbf{R}^{2}$ & $x_{\text {avg }}$ & $\begin{array}{r}b^{*} \\
(1 \mathrm{~min})\end{array}$ & $\begin{array}{r}b^{*} \\
(5 \mathrm{~min})\end{array}$ & $\begin{array}{r}b^{*} \\
(15 \mathrm{~min})\end{array}$ & $\begin{array}{r}b^{*} \\
\text { (30min) }\end{array}$ & $\begin{array}{r}\text { df } \\
(1 \mathrm{~min})\end{array}$ & $\begin{array}{r}\text { df } \\
(5 \mathrm{~min})\end{array}$ & $\begin{array}{r}\text { df } \\
(15 \mathrm{~min}) \\
\end{array}$ & $\begin{array}{r}d f \\
(30 \mathrm{~min})\end{array}$ \\
\hline 1 & 20 & 0.413 & 1.824 & 5.27 & 1.08 & 0.94 & 0.58 & & 6.058 & 6.511 & 5.553 & & 38 & 38 & 30 \\
\hline 5 & 20 & 0.754 & 1.824 & 6.06 & 2.23 & 0.87 & 0.37 & 5.273 & & 6.511 & 5.553 & 38 & & 38 & 30 \\
\hline 15 & 20 & 0.679 & 1.824 & 6.51 & 2.52 & 0.90 & 0.37 & 5.273 & 6.058 & & 5.553 & 38 & 38 & & 30 \\
\hline 30 & 12 & 0.580 & 0.725 & 5.55 & 2.83 & 0.87 & 0.18 & 5.273 & 6.058 & 6.511 & & 30 & 30 & 30 & \\
\hline
\end{tabular}

\begin{tabular}{|c|c|c|c|c|c|c|c|c|c|c|c|}
\hline $\begin{array}{l}t_{\text {calc }} \\
\text { (vs 1') }\end{array}$ & $\begin{array}{l}t_{\text {calc }} \\
\text { (vs 5') }\end{array}$ & $\begin{array}{l}t_{\text {calc }} \\
\text { (vs 15') }\end{array}$ & $\begin{array}{l}t_{\text {calc }} \\
\text { (vs 30') }\end{array}$ & $t_{\text {crit }}$ & $t_{\text {crit }}$ & $t_{\text {crit }}$ & $t_{\text {crit }}$ & $\begin{array}{l}\text { Sign } \\
\text { level }\end{array}$ & at $p$ & 05 (a & $.025)$ \\
\hline & -1.816 & -3.062 & -0.636 & & 2.025 & 2.025 & 2.042 & & no & yes & no \\
\hline 1.816 & & -0.854 & 0.854 & 2.025 & & 2.025 & 2.042 & no & & no & no \\
\hline 3.062 & 0.854 & & 1.717 & 2.025 & 2.025 & & 2.042 & yes & no & & no \\
\hline 0.636 & -0.854 & -1.717 & & 2.042 & 2.042 & 2.042 & & no & no & no & \\
\hline
\end{tabular}


D.2.3 Oxidant Demand Coefficients and Hypothesis Testing for Enterococci

\begin{tabular}{|c|c|c|c|c|c|c|c|c|c|c|c|c|c|c|c|}
\hline $\begin{array}{r}\text { time } \\
(\min )\end{array}$ & $\mathbf{n}$ & $\mathbf{s}$ & SS $_{x}$ & b & d & $\mathbf{R}^{2}$ & $x_{\text {avg }}$ & $\begin{array}{r}b^{*} \\
(1 \mathrm{~min})\end{array}$ & $\begin{array}{r}b^{*} \\
(5 \mathrm{~min})\end{array}$ & $\begin{array}{r}b^{*} \\
(15 \mathrm{~min})\end{array}$ & $\begin{array}{r}b^{*} \\
\text { (30min) }\end{array}$ & $\begin{array}{r}d f \\
(1 \mathrm{~min})\end{array}$ & $\begin{array}{r}d f \\
(5 \mathrm{~min})\end{array}$ & $\begin{array}{r}d f \\
(15 \mathrm{~min})\end{array}$ & $\begin{array}{r}d f \\
\text { (30min) }\end{array}$ \\
\hline 1 & 20 & 0.743 & 4.189 & 2.79 & 1.76 & 0.77 & 0.13 & & 3.529 & 3.423 & 3.706 & & 38 & 34 & 30 \\
\hline 5 & 20 & 0.550 & 4.189 & 3.53 & 2.75 & 0.91 & 0.13 & 2.788 & & 3.423 & 3.706 & 38 & & 34 & 30 \\
\hline 15 & 16 & 0.462 & 2.995 & 3.42 & 3.04 & 0.91 & -0.02 & 2.788 & 3.529 & & 3.706 & 34 & 34 & & 26 \\
\hline 30 & 12 & 0.462 & 1.232 & 3.71 & 3.32 & 0.89 & -0.18 & 2.788 & 3.529 & 3.423 & & 30 & 30 & 26 & \\
\hline
\end{tabular}

\begin{tabular}{|c|c|c|c|c|c|c|c|c|c|c|c|}
\hline \multirow[t]{2}{*}{$\begin{array}{l}t_{\text {calc }} \\
\text { (vs 1') }\end{array}$} & \multirow{2}{*}{$\begin{array}{c}\begin{array}{l}\mathbf{t}_{\text {calc }} \\
\text { (vs 5') }\end{array} \\
-2.346\end{array}$} & \multirow{2}{*}{$\begin{array}{l}\mathbf{t}_{\text {calc }} \\
\text { (vs 15') }\end{array}$} & \multirow{2}{*}{$\begin{array}{r}\begin{array}{l}\mathbf{t}_{\text {calc }} \\
\text { (vs 30') }\end{array} \\
-2.509\end{array}$} & \multirow[t]{2}{*}{$t_{\text {crit }}$} & \multirow{2}{*}{$\frac{\mathbf{t}_{\text {crit }}}{2.025}$} & \multirow{2}{*}{$\frac{t_{\text {crit }}}{2.033}$} & \multirow{2}{*}{$\frac{t_{\text {crit }}}{2.042}$} & \multicolumn{4}{|c|}{$\begin{array}{l}\text { Significant at } p=0.05(\text { alpha }=0.025) \\
\text { level? }\end{array}$} \\
\hline & & & & & & & & & yes & no & yes \\
\hline 2.346 & & 0.397 & -0.576 & 2.025 & & 2.033 & 2.042 & yes & & no & no \\
\hline 1.997 & -0.397 & & -0.891 & 2.033 & 2.033 & & 2.056 & no & no & & no \\
\hline 2.509 & 0.576 & 0.891 & & 2.042 & 2.042 & 2.056 & & yes & no & no & \\
\hline
\end{tabular}


D.2.4 Oxidant Demand Coefficients and Hypothesis Testing for Vibrio cholerae

\begin{tabular}{|c|c|c|c|c|c|c|c|c|c|c|c|c|c|c|c|}
\hline $\begin{array}{r}\text { time } \\
(\min )\end{array}$ & $\mathrm{n}$ & $\mathbf{s}$ & $S_{S_{x}}$ & b & d & $\mathbf{R}_{2}$ & $x_{\text {avg }}$ & $\begin{array}{r}b^{*} \\
(1 \mathrm{~min})\end{array}$ & $\begin{array}{r}b^{*} \\
\text { (5min) }\end{array}$ & $\begin{array}{r}b^{*} \\
\text { (15min) }\end{array}$ & $\begin{array}{r}b^{*} \\
\text { (30min) }\end{array}$ & $\begin{array}{r}d f \\
(1 \mathrm{~min})\end{array}$ & $\begin{array}{r}d f \\
(5 \mathrm{~min})\end{array}$ & $\begin{array}{r}d f \\
(15 m i n)\end{array}$ & $\begin{array}{r}d f \\
(30 \mathrm{~min})\end{array}$ \\
\hline 1 & 20 & 0.304 & 2.837 & 2.10 & 1.78 & 0.88 & 0.28 & & 2.555 & 2.438 & 2.662 & & 38 & 34 & 30 \\
\hline 5 & 20 & 0.212 & 2.837 & 2.55 & 2.54 & 0.96 & 0.28 & 2.098 & & 2.438 & 2.662 & 38 & & 34 & 30 \\
\hline 15 & 16 & 0.300 & 2.237 & 2.44 & 2.76 & 0.90 & 0.17 & 2.098 & 2.555 & & 2.662 & 34 & 34 & & 26 \\
\hline 30 & 12 & 0.347 & 0.983 & 2.66 & 2.94 & 0.85 & 0.032 & 2.098 & 2.555 & 2.438 & & 30 & 30 & 26 & \\
\hline
\end{tabular}

\begin{tabular}{|c|c|c|c|c|c|c|c|c|c|c|c|}
\hline $\begin{array}{l}t_{\text {calc }} \\
\text { (vs 1') }\end{array}$ & $\begin{array}{l}t_{\text {calc }} \\
\text { (vs 5') }\end{array}$ & $\begin{array}{l}t_{\text {calc }} \\
\text { (vs 15') }\end{array}$ & $\begin{array}{l}t_{\text {calc }} \\
\text { (vs 30') }\end{array}$ & $t_{\text {crit }}$ & $t_{\text {crit }}$ & $t_{\text {crit }}$ & $t_{\text {crit }}$ & $\begin{array}{l}\text { Sign } \\
\text { level }\end{array}$ & $t$ at $p$ & 5 (al) & $=0.025)$ \\
\hline & -2.975 & -1.788 & -2.392 & & 2.025 & 2.033 & 2.042 & & yes & no & yes \\
\hline 2.975 & & 0.726 & -0.530 & 2.025 & & 2.033 & 2.042 & yes & & no & no \\
\hline 1.788 & -0.726 & & -0.879 & 2.033 & 2.033 & & 2.056 & no & no & & no \\
\hline 2.392 & 0.530 & 0.879 & & 2.042 & 2.042 & 2.056 & & yes & no & no & \\
\hline
\end{tabular}


D.3 Summary Statistics for $\mathrm{pH}$ and Salinity Effects and Anti-Clumping Measures

Table D-2: Summary of pH Statistics for 0.75 mg/l Ferrate Dosage.

\begin{tabular}{|c|c|c|c|c|c|}
\hline \multicolumn{6}{|c|}{ Comparison: All three $\mathrm{pH}$ condtions. } \\
\hline Variable & DF & $\begin{array}{l}\text { Sum of } \\
\text { Squares }\end{array}$ & $\begin{array}{l}\text { Mean } \\
\text { Square }\end{array}$ & F Value & $\operatorname{Pr}(\mathrm{F})$ \\
\hline $\mathrm{pH}$ & 2 & 5.86 & 2.93 & 54.5 & $2.7 \times 10^{-8}$ \\
\hline Time & 3 & 10.45 & 3.48 & 63.6 & $8.9 \times 10^{-10}$ \\
\hline Residuals & 18 & 0.98 & 0.054 & & \\
\hline \multicolumn{6}{|c|}{ Comparison: Acid vs. neutral pH. } \\
\hline Variable & DF & $\begin{array}{l}\text { Sum of } \\
\text { Squares }\end{array}$ & $\begin{array}{l}\text { Mean } \\
\text { Square }\end{array}$ & F Value & $\operatorname{Pr}(F)$ \\
\hline $\mathrm{pH}$ & 1 & 3.80 & 3.80 & 56.8 & $1.2 \times 10^{-5}$ \\
\hline Time & 3 & 7.61 & 2.54 & 37.9 & $4.3 \times 10^{-6}$ \\
\hline Residuals & 11 & 0.74 & 0.067 & & \\
\hline \multicolumn{6}{|c|}{ Comparison: Alkaline vs. neutral pH. } \\
\hline Variable & DF & $\begin{array}{l}\text { Sum of } \\
\text { Squares }\end{array}$ & $\begin{array}{l}\text { Mean } \\
\text { Square }\end{array}$ & F Value & $\operatorname{Pr}(F)$ \\
\hline $\mathrm{pH}$ & 1 & 0.071 & 0.071 & 4.01 & 0.07 \\
\hline Time & 3 & 4.84 & 1.61 & 90.5 & $5.0 \times 10^{-8}$ \\
\hline Residuals & 11 & 0.19 & 0.017 & & \\
\hline
\end{tabular}


Table D-3: Summary of pH Statistics for $1.5 \mathrm{mg} / \mathrm{l}$ Ferrate Dosage.

\begin{tabular}{|l|r|r|r|r|r|}
\hline \multicolumn{7}{|c|}{ Comparison: All three $\mathrm{pH}$ condtions. } \\
\hline Variable & DF & $\begin{array}{r}\text { Sum of } \\
\text { Squares }\end{array}$ & $\begin{array}{r}\text { Mean } \\
\text { Square }\end{array}$ & F Value & $\operatorname{Pr}(\mathrm{F})$ \\
\hline $\mathrm{pH}$ & 2 & 5.93 & 2.96 & 129.3 & $2.1 \times 10^{-11}$ \\
\hline Time & 3 & 10.1 & 3.36 & 146.6 & $7.8 \times 10^{-13}$ \\
\hline Residuals & 18 & 0.41 & 0.023 & & \\
\hline \multicolumn{7}{|c|}{} \\
\hline \multicolumn{7}{|c|}{ Comparison: Acid vs. neutral pH. } \\
\hline Variable & DF & Squares & Square & F Value & $\operatorname{Pr}(\mathrm{F})$ \\
\hline pH & 1 & 4.51 & 4.51 & 244.8 & $7.3 \times 10^{-9}$ \\
\hline Time & 3 & 7.10 & 2.37 & 128.6 & $7.6 \times 10^{-9}$ \\
\hline Residuals & 11 & 0.20 & 0.018 & & \\
\hline \multicolumn{7}{|c|}{} \\
\hline \multicolumn{7}{|c|}{ Comparison: Alkaline vs. neutral pH. } \\
\hline Variable & DF & Squares & Square & F Value & $\operatorname{Pr}(\mathrm{F})$ \\
\hline pH & 1 & 0.00092 & 0.00092 & 0.041 & 0.84 \\
\hline Time & 3 & 5.91 & 1.97 & 86.8 & $1.0 \times 10^{-7}$ \\
\hline Residuals & 11 & 0.25 & 0.023 & & \\
\hline
\end{tabular}

Table D.3-3: Summary of Statistics for Salinity Effect

\begin{tabular}{|l|r|r|r|r|r|}
\hline Variable & DF & $\begin{array}{r}\text { Sum of } \\
\text { Squares }\end{array}$ & $\begin{array}{r}\text { Mean } \\
\text { Square }\end{array}$ & F Value & $\operatorname{Pr}(F)$ \\
\hline Salinity & 1 & 0.36 & 0.36 & 3.58 & 0.063 \\
\hline Time & 3 & 24.7 & 8.23 & 81.4 & $<10-8$ \\
\hline Dosage & 4 & 369 & 92.3 & 913.0 & $<10-8$ \\
\hline Residuals & 71 & 7.18 & 0.10 & & \\
\hline
\end{tabular}


Table D-4: Summary of Statistics for Anti-Clumping (AC) Measures.

\begin{tabular}{|l|r|r|r|r|r|}
\hline \multicolumn{6}{|c|}{ Comparison: Low-Speed Centrifugation vs. Normal Prepartion. } \\
\hline Variable & DF & $\begin{array}{r}\text { Sum of } \\
\text { Squares }\end{array}$ & $\begin{array}{r}\text { Mean } \\
\text { Square }\end{array}$ & F Value & $\operatorname{Pr}(\mathrm{F})$ \\
\hline AC & 1 & 4.36 & 4.36 & 16.7 & $2.1 \times 10^{-4}$ \\
Measure & 3 & 37.7 & 12.6 & 47.9 & $<10^{-10}$ \\
\hline Dosage & 1 & 4.31 & 4.31 & 16.5 & $2.2 \times 10^{-4}$ \\
\hline Time & 40 & 10.5 & 0.26 & & \\
\hline Residuals & 40 & & \\
\hline \multicolumn{7}{|c|}{ Comparison: Vortexing vs. Normal Prepartion. } \\
\hline \multicolumn{7}{|r|}{} & Sum of & Mean & & \\
\hline Variable & DF & Squares & Square & F Value & $\operatorname{Pr}(\mathrm{F})$ \\
\hline AC & 1 & 5.94 & 5.94 & 8.20 & 0.0067 \\
Measure & 3 & 32.7 & 10.9 & 15.1 & $1.2 \times 10^{-6}$ \\
\hline Dosage & 1 & 21.4 & 21.4 & 29.5 & $3.2 \times 10^{-6}$ \\
\hline Time & 39 & 28.2 & 0.72 & & \\
\hline Residuals & \multicolumn{7}{|c|}{} \\
\hline
\end{tabular}


APPENDIX E: RAW EXPERIMENTAL DATA 
Experiment numbers correspond to numbers in the lab notebooks, which are numbered chronologically. Raw data can also be supplied as Excel files upon request. Gaps in the numbering sequences in this appendix are attributable to experiments to establish protocol or to experiments of questionable success. Experiments are arranged here by purpose. Nd means "not done", awcg means "area with confluent growth".

\section{E.1 Dosage Response Experiments with E. coli}

\begin{tabular}{|c|c|c|c|c|c|}
\hline Expt.\# & \multicolumn{5}{|l|}{23} \\
\hline Date of Expt.: & \multicolumn{5}{|l|}{$4 / 12 / 2005$} \\
\hline Date HPC read: & \multicolumn{5}{|l|}{$4 / 15 / 2005$} \\
\hline Purpose: & \multicolumn{5}{|c|}{$\begin{array}{l}\text { Investigate effect of time on disinfection } \mathrm{w} / 2 \mathrm{mg} / \mathrm{l} \\
\text { ferrate }\end{array}$} \\
\hline WS: & \multicolumn{5}{|c|}{$\begin{array}{l}\text { E. Coli in IO:NB, } 600 \text { mls as a } 5: 1 \text { dilution, grown for } \\
4 \text { days on shaker table at } R T \text {, then spun and } \\
\text { resuspended in } 5: 1 \mathrm{IO}: \mathrm{dH} 2 \mathrm{O}\end{array}$} \\
\hline \multicolumn{6}{|c|}{ Heterotrophic Plate Count } \\
\hline & & $\begin{array}{l}\text { Number of } \\
\text { Colonies }\end{array}$ & & & \\
\hline Specimen/QC & $\begin{array}{l}\text { Dilution } \\
\left(10^{\wedge}-n\right)\end{array}$ & Plate 1 & $\begin{array}{l}\text { Plat } \\
\text { e } 2\end{array}$ & $\begin{array}{l}\text { ave } \\
\text { count }\end{array}$ & $\begin{array}{l}\text { Colony } \\
\text { Count }\end{array}$ \\
\hline QC open, hood & & 0 & & & 0 \\
\hline QC closed, hood & & 0 & & & 0 \\
\hline QC open, counter & & 0 & & & 0 \\
\hline dilution buffer & & 0 & & & 0 \\
\hline Instant Ocean & & nd & & & nd \\
\hline \multicolumn{6}{|c|}{$\begin{array}{l}\text { All specs. w/ferrate stopped w/TS; all } \\
\text { concs. are } 2 \mathrm{mg} / \mathrm{l}\end{array}$} \\
\hline & & & & & \\
\hline WS 0' & 6 & 18 & 22 & 20 & $\begin{array}{r}2.00 \mathrm{E}+0 \\
7\end{array}$ \\
\hline WS 0' & 5 & 206 & 199 & $\begin{array}{r}202 . \\
5\end{array}$ & $\begin{array}{r}2.03 E+0 \\
7\end{array}$ \\
\hline $2 \mathrm{mg} / \mathrm{l}, 10^{\prime}$ & 3 & 129 & 153 & 141 & $\begin{array}{r}1.41 \mathrm{E}+0 \\
5\end{array}$ \\
\hline $2 \mathrm{mg} / \mathrm{l}, 25^{\prime}$ & 3 & 58 & 69 & 63.5 & $\begin{array}{r}6.35 \mathrm{E}+0 \\
4\end{array}$ \\
\hline $2 \mathrm{mg} / \mathrm{l}, 2^{\prime}$ & 4 & 7 & 5 & 6 & $\begin{array}{r}6.00 \mathrm{E}+0 \\
4\end{array}$ \\
\hline $2 \mathrm{mg} / \mathrm{l}, 50^{\prime}$ & 2 & 158 & 177 & $\begin{array}{r}167 . \\
5\end{array}$ & $\begin{array}{r}1.68 \mathrm{E}+0 \\
4 \\
\end{array}$ \\
\hline $3 \mathrm{mg} / \mathrm{l}, 50^{\prime}$ & 3 & 18 & 35 & 26.5 & $\begin{array}{r}2.65 \mathrm{E}+0 \\
4\end{array}$ \\
\hline
\end{tabular}




\begin{tabular}{|l|r|r|r|r|r|} 
& \\
$2 \mathrm{mg} / \mathrm{l}, 75^{\prime}$ & 2 & $7.40 \mathrm{E}+0$ \\
\hline
\end{tabular}




\begin{tabular}{|l|l|}
\hline Expt. \#: & 30 \\
\hline Date of Expt.: & $5 / 3 / 2005$ \\
\hline Date HPC read: & $5 / 6 / 2005$ \\
\hline Purpose: & $\begin{array}{l}\text { Investigate effect of time on effectiveness of disinfection } \mathrm{w} / 5 \mathrm{mg} / \mathrm{l} \\
\text { ferrate }\end{array}$ \\
\hline WS: & $\begin{array}{l}\text { E Coli in IO:NB, } 600 \mathrm{mls} \text { as a } 5: 1 \text { dilution, grown for } 2 \text { days on shaker } \\
\text { table at RT, then spun and resuspended in 5:1 IO:dH2O }\end{array}$ \\
\hline
\end{tabular}

\begin{tabular}{|c|c|c|c|c|c|}
\hline \multicolumn{6}{|c|}{ Heterotrophic Plate Count } \\
\hline & & $\begin{array}{l}\text { Number of } \\
\text { Colonies }\end{array}$ & & & \\
\hline Specimen/QC & $\begin{array}{l}\text { Dilution } \\
\left(10^{\wedge}-n\right)\end{array}$ & Plate 1 & $\begin{array}{l}\text { Plat } \\
\text { e } 2\end{array}$ & $\begin{array}{l}\text { ave } \\
\text { count }\end{array}$ & $\begin{array}{l}\text { Colony } \\
\text { Count }\end{array}$ \\
\hline QC open, hood & & 0 & & & 0 \\
\hline QC closed, hood & & 0 & & & 0 \\
\hline QC open, counter & & 3 & & & 3 \\
\hline dilution buffer & & 0 & & & 0 \\
\hline Instant Ocean & & nd & & & nd \\
\hline \multicolumn{6}{|c|}{$\begin{array}{l}\text { All specs. w/ferrate stopped w/TS; all } \\
\text { concs. are } 5 \mathrm{mg} / \mathrm{l}\end{array}$} \\
\hline WS 0' & 6 & 63 & 66 & 64.5 & $\begin{array}{r}6.45 \mathrm{E}+0 \\
7 \\
\end{array}$ \\
\hline WS 0' & 7 & 6 & 9 & 7.5 & $\begin{array}{r}7.50 \mathrm{E}+0 \\
7 \\
\end{array}$ \\
\hline $5 \mathrm{mg} / \mathrm{l}, 15^{\prime}$ & 1 & 2 & 1 & 1.5 & $\begin{array}{r}1.50 \mathrm{E}+0 \\
1 \\
\end{array}$ \\
\hline $5 \mathrm{mg} / \mathrm{l}, 15^{\prime}$ & $1,1 \mathrm{ml}$ & 35 & $\mathrm{cg}$ & 35 & $\begin{array}{r}3.50 \mathrm{E}+0 \\
1 \\
\end{array}$ \\
\hline $5 \mathrm{mg} / \mathrm{l}, 60^{\prime}$ & 1 & 0 & 0 & 0 & $\begin{array}{r}0.00 \mathrm{E}+0 \\
0\end{array}$ \\
\hline $5 \mathrm{mg} / \mathrm{l}, 60^{\prime}$ & $1,1 \mathrm{ml}$ & 0 & 0 & 0 & $\begin{array}{r}0.00 \mathrm{E}+0 \\
0\end{array}$ \\
\hline
\end{tabular}




\begin{tabular}{|l|l|}
\hline Expt. \#: & 32 \\
\hline Date of Expt.: & $5 / 3 / 2005$ \\
\hline Date HPC read: & $5 / 17 / 2005$ \\
\hline Purpose: & Investigate effect of time on effectiveness of disinfection w/5 mg/l ferrate \\
\hline WS: & $\begin{array}{l}\text { E Coli in IO:NB, } 600 \text { mls as a } 5: 1 \text { dilution, grown for } 2 \text { days on shaker table at } \\
\text { RT, then spun and resuspended in } 5: 1 \text { IO:dH2O }\end{array}$ \\
\hline
\end{tabular}

\begin{tabular}{|c|c|c|c|c|c|}
\hline \multicolumn{6}{|c|}{ Heterotrophic Plate Count } \\
\hline & & $\begin{array}{l}\text { Number of } \\
\text { Colonies }\end{array}$ & & & \\
\hline Specimen/QC & $\begin{array}{l}\text { Dilution } \\
\left(10^{\wedge}-n\right)\end{array}$ & Plate 1 & $\begin{array}{l}\text { Plat } \\
\text { e } 2\end{array}$ & $\begin{array}{l}\text { ave } \\
\text { count }\end{array}$ & $\begin{array}{l}\text { Colony } \\
\text { Count }\end{array}$ \\
\hline QC open, hood & & 0 & & & 0 \\
\hline QC closed, hood & & 0 & & & 0 \\
\hline QC open, counter & & 1 & & & 1 \\
\hline dilution buffer & & nd & & & nd \\
\hline Instant Ocean & & nd & & & nd \\
\hline \multicolumn{6}{|c|}{$\begin{array}{l}\text { all specs. w/ferrate stopped w/TS; all } \\
\text { concs. are } 5 \mathrm{mg} / \mathrm{l}\end{array}$} \\
\hline & & & & & \\
\hline WS 0' & 5 & 125 & 119 & 122 & $\begin{array}{r}1.22 \mathrm{E}+0 \\
7\end{array}$ \\
\hline WS 0' & 6 & 23 & 14 & 18.5 & $\begin{array}{r}1.85 \mathrm{E}+0 \\
7\end{array}$ \\
\hline 5 mg/l, 15' & 1 & 18 & 16 & 17 & $\begin{array}{r}1.70 \mathrm{E}+0 \\
2\end{array}$ \\
\hline $5 \mathrm{mg} / \mathrm{l}, 15^{\prime}$ & $1,1 \mathrm{ml}$ & 38 & $\mathrm{cg}$ & 38 & $\begin{array}{r}3.80 \mathrm{E}+0 \\
1\end{array}$ \\
\hline $5 \mathrm{mg} / \mathrm{l}, 60^{\prime}$ & 1 & 0 & 0 & 0 & $\begin{array}{r}0.00 \mathrm{E}+0 \\
0\end{array}$ \\
\hline $5 \mathrm{mg} / \mathrm{l}, 60^{\prime}$ & $1,1 \mathrm{ml}$ & 0 & 0 & 0 & $\begin{array}{r}0.00 \mathrm{E}+0 \\
0\end{array}$ \\
\hline
\end{tabular}




\begin{tabular}{|l|l|}
\hline Expt. \#: & 34 \\
\hline Date of Expt.: & $5 / 3 / 2005$ \\
\hline Date HPC read: & $5 / 6 / 2005$ \\
\hline Purpose: & Investigate effect of time on effectiveness of disinfection w/5 mg/l ferrate \\
\hline WS: & $\begin{array}{l}\text { E. Coli in IO:NB, } 600 \text { mls as a } 5: 1 \text { dilution, grown for } 2 \text { days on shaker table } \\
\text { at RT, then spun and resuspended in 5:1 IO:dH2O }\end{array}$ \\
\hline
\end{tabular}

\begin{tabular}{|c|c|c|c|c|c|}
\hline \multicolumn{6}{|c|}{ Heterotrophic Plate Count } \\
\hline & & $\begin{array}{l}\text { Number of } \\
\text { Colonies }\end{array}$ & & & \\
\hline Specimen/QC & $\begin{array}{l}\text { Dilution } \\
\left(10^{\wedge}-n\right)\end{array}$ & Plate 1 & $\begin{array}{l}\text { Plat } \\
\text { e } 2\end{array}$ & $\begin{array}{l}\text { ave } \\
\text { count }\end{array}$ & $\begin{array}{l}\text { Colony } \\
\text { Count }\end{array}$ \\
\hline QC open, hood & & 0 & & & 0 \\
\hline QC closed, hood & & nd & & & nd \\
\hline QC open, counter & & nd & & & nd \\
\hline dilution buffer & & 0 & & & 0 \\
\hline Instant Ocean & & nd & & & nd \\
\hline \multicolumn{6}{|c|}{$\begin{array}{l}\text { all specs. w/ferrate stopped w/TS; all } \\
\text { concs. are } 5 \mathrm{mg} / \mathrm{l}\end{array}$} \\
\hline & & & & & \\
\hline WS 0' & 5 & 111 & 130 & $\begin{array}{r}120 . \\
5\end{array}$ & $\begin{array}{r}1.21 \mathrm{E}+0 \\
7\end{array}$ \\
\hline WS 0' & 6 & 15 & 19 & 17 & $\begin{array}{r}1.70 \mathrm{E}+0 \\
7 \\
\end{array}$ \\
\hline 5 mg/l, $15^{\prime}$ & 1 & 0 & 0 & 0 & $\begin{array}{r}0.00 \mathrm{E}+0 \\
0\end{array}$ \\
\hline 5 mg/l, 15' & $1,1 \mathrm{ml}$ & 3 & 0 & 1.5 & $\begin{array}{r}1.50 \mathrm{E}+0 \\
0\end{array}$ \\
\hline $5 \mathrm{mg} / \mathrm{l}, 60^{\prime}$ & 1 & 0 & 0 & 0 & $\begin{array}{r}0.00 \mathrm{E}+0 \\
0 \\
\end{array}$ \\
\hline $5 \mathrm{mg} / \mathrm{l}, 60^{\prime}$ & $1,1 \mathrm{ml}$ & 0 & 0 & 0 & $\begin{array}{r}0.00 \mathrm{E}+0 \\
0\end{array}$ \\
\hline
\end{tabular}




\begin{tabular}{|l|l|}
\hline Expt. \#: & 45 \\
\hline Date of Expt.: & $5 / 25 / 2005$ \\
\hline Date HPC read: & $5 / 30 / 2005$ \\
\hline Purpose: & Investigate short contact times for disinfection w/2 mg/l ferrate \\
\hline WS: & $\begin{array}{l}\text { E Coli in IO:NB, } 600 \text { mls as a 5:1 dilution, grown for } 4 \text { days on shaker table at } \\
\text { RT, then spun and resuspended in } 100 \mathrm{mls} \mathrm{5:1} \mathrm{IO:dH2O}\end{array}$ \\
\hline
\end{tabular}

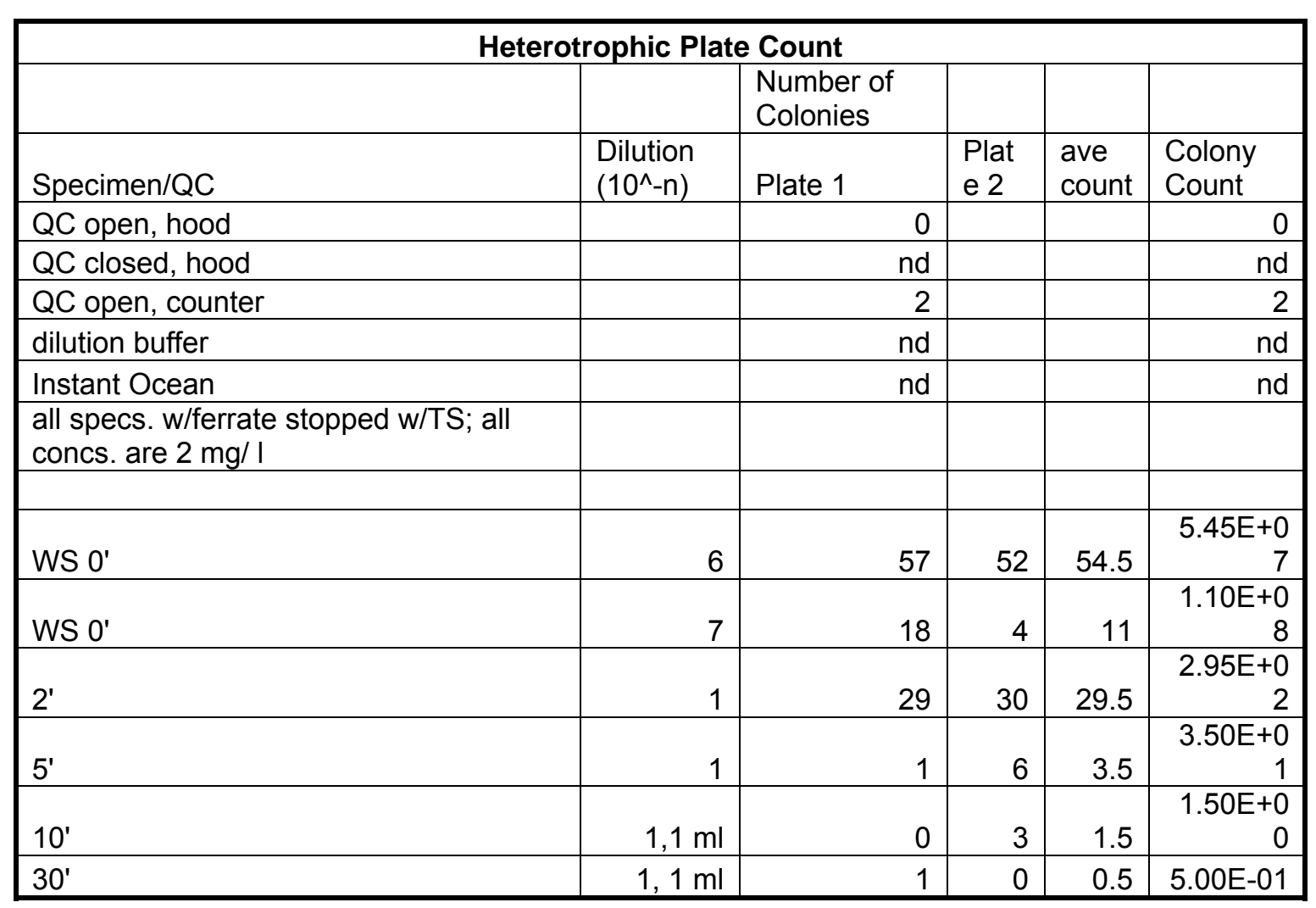




\begin{tabular}{|l|l|}
\hline Expt. \#: & 51 \\
\hline Date of Expt.: & $6 / 7 / 2005$ \\
\hline Date HPC read: & $6 / 13 / 2005$ \\
\hline Purpose: & Investigate short contact times for disinfection w/2 mg/l ferrate \\
\hline WS: & $\begin{array}{l}\text { E Coli in IO:NB, } 600 \text { mls as a 5:1 dilution, grown for } 4 \text { days on shaker table at } \\
\text { RT, then spun and resuspended in 200 mls 5:1 IO:dH2O }\end{array}$ \\
\hline
\end{tabular}

\begin{tabular}{|c|c|c|c|c|c|}
\hline \multicolumn{6}{|c|}{ Heterotrophic Plate Count } \\
\hline & & $\begin{array}{l}\text { Number of } \\
\text { Colonies }\end{array}$ & & & \\
\hline Specimen/QC & $\begin{array}{l}\text { Dilution } \\
\left(10^{\wedge}-n\right)\end{array}$ & Plate 1 & $\begin{array}{l}\text { Plat } \\
\text { e } 2\end{array}$ & $\begin{array}{l}\text { ave } \\
\text { count }\end{array}$ & $\begin{array}{l}\text { Colony } \\
\text { Count }\end{array}$ \\
\hline QC open, hood & & 0 & & & 0 \\
\hline QC closed, hood & & nd & & & nd \\
\hline QC open, counter & & 3 & & & 3 \\
\hline dilution buffer & & nd & & & nd \\
\hline Instant Ocean & & nd & & & nd \\
\hline \multicolumn{6}{|c|}{$\begin{array}{l}\text { all specs. w/ferrate stopped w/TS; all } \\
\text { concs. are } 2 \mathrm{mg} / \mathrm{l}\end{array}$} \\
\hline & & & & & \\
\hline WS $0^{\prime}$ & 5 & 53 & 51 & 52 & $\begin{array}{r}5.20 \mathrm{E}+0 \\
6\end{array}$ \\
\hline WS 0' & 6 & 5 & 6 & 5.5 & $\begin{array}{r}5.50 \mathrm{E}+0 \\
6\end{array}$ \\
\hline $2^{\prime}$ & 1 & 9 & 13 & 11 & $\begin{array}{r}1.10 \mathrm{E}+0 \\
2\end{array}$ \\
\hline $5^{\prime}$ & 1 & 2 & 2 & 2 & $\begin{array}{r}2.00 \mathrm{E}+0 \\
1 \\
\end{array}$ \\
\hline $10^{\prime}$ & $1,1 \mathrm{ml}$ & awcg & 2 & 2 & $\begin{array}{r}2.00 \mathrm{E}+0 \\
0\end{array}$ \\
\hline $30^{\prime}$ & $1,1 \mathrm{ml}$ & 1 & 0 & 0 & $\begin{array}{r}0.00 \mathrm{E}+0 \\
0\end{array}$ \\
\hline
\end{tabular}




\begin{tabular}{|l|l|}
\hline Expt. \#: & 53 \\
\hline Date of Expt.: & $6 / 15 / 2005$ \\
\hline Date HPC read: & $6 / 21 / 2005$ \\
\hline Purpose: & Investigate short contact times for disinfection w/1.5 mg/l ferrate \\
\hline WS: & $\begin{array}{l}\text { E Coli in IO:NB, } 600 \text { mls as a } 5: 1 \text { dilution, grown for } 4 \text { days on shaker table at } \\
\text { RT, then spun and resuspended in } 100 \mathrm{mls} \mathrm{5:1} \mathrm{IO:dH2O}\end{array}$ \\
\hline
\end{tabular}

\begin{tabular}{|c|c|c|c|c|c|}
\hline \multicolumn{6}{|c|}{ Heterotrophic Plate Count } \\
\hline & & $\begin{array}{l}\text { Number of } \\
\text { Colonies }\end{array}$ & & & \\
\hline Specimen/QC & $\begin{array}{l}\text { Dilution } \\
\left(10^{\wedge}-n\right)\end{array}$ & Plate 1 & $\begin{array}{l}\text { Plat } \\
\text { e } 2\end{array}$ & $\begin{array}{l}\text { ave } \\
\text { coun } \\
t\end{array}$ & $\begin{array}{l}\text { Colony } \\
\text { Count }\end{array}$ \\
\hline QC open, hood & & 0 & & & 0 \\
\hline QC closed, hood & & nd & & & nd \\
\hline QC open, counter & & 7 & & & 7 \\
\hline dilution buffer & & 0 & & & 0 \\
\hline Instant Ocean & & nd & & & nd \\
\hline \multicolumn{6}{|c|}{$\begin{array}{l}\text { all specs. w/ferrate stopped w/TS; all } \\
\text { concs. are } 1.5 \mathrm{mg} / \mathrm{I}\end{array}$} \\
\hline & & & & & \\
\hline WS 0' & 5 & 34 & 30 & 32 & $\begin{array}{r}3.20 \mathrm{E}+0 \\
6 \\
\end{array}$ \\
\hline WS 0' & 6 & 1 & 5 & 3 & $\begin{array}{r}3.00 \mathrm{E}+0 \\
6 \\
\end{array}$ \\
\hline $2^{\prime}$ & 2 & 16 & 19 & 17.5 & $\begin{array}{r}1.75 \mathrm{E}+0 \\
3\end{array}$ \\
\hline $5^{\prime}$ & 1 & 102 & 93 & 97.5 & $\begin{array}{r}9.75 \mathrm{E}+0 \\
2 \\
\end{array}$ \\
\hline $8^{\prime}$ & 2 & 2 & 5 & 3.5 & $\begin{array}{r}3.50 \mathrm{E}+0 \\
2 \\
\end{array}$ \\
\hline $10^{\prime}$ & 1 & 24 & 27 & 25.5 & $\begin{array}{r}2.55 \mathrm{E}+0 \\
2 \\
\end{array}$ \\
\hline $15^{\prime}$ & 1 & 8 & 20 & 14 & $\begin{array}{r}1.40 \mathrm{E}+0 \\
2\end{array}$ \\
\hline
\end{tabular}




\begin{tabular}{|l|l|}
\hline Expt. \#: & 59 \\
\hline Date of Expt.: & $6 / 27 / 2005$ \\
\hline $\begin{array}{l}\text { Date HPC } \\
\text { read: }\end{array}$ & $7 / 1 / 2005$ \\
\hline Purpose: & Investigate short contact times of $0.5 \mathrm{mg} / \mathrm{l}$ ferrate on E. coli \\
\hline WS: & $\begin{array}{l}\text { E. coli in IO:NB, } 600 \mathrm{mls} \text { as a } 5: 1 \text { dilution, grown for } 4 \text { days on shaker table at RT, } \\
\text { then spun and resuspended in 5:1 IO:dH2O }\end{array}$ \\
\hline
\end{tabular}

\begin{tabular}{|c|c|c|c|c|c|}
\hline \multicolumn{6}{|c|}{ Heterotrophic Plate Count } \\
\hline & & \multicolumn{2}{|c|}{$\begin{array}{c}\text { Number of } \\
\text { Colonies }\end{array}$} & & \\
\hline Specimen/QC & Dilution $\left(10^{\wedge}-n\right)$ & $\begin{array}{r}\text { Plate } \\
1\end{array}$ & $\begin{array}{r}\text { Plate } \\
2\end{array}$ & Ave. Count & Colony Count \\
\hline QC open, hood & & 1 & & & 1 \\
\hline QC closed, hood & & nd & & & nd \\
\hline QC open, counter & & 1 & & & 1 \\
\hline dilution buffer & & 0 & & & 0 \\
\hline Instant Ocean & & nd & & & nd \\
\hline \multicolumn{6}{|c|}{ all specs. w/ferrate stopped w/TS; all concs. are $0.5 \mathrm{mg} / \mathrm{l}$} \\
\hline & & & & & \\
\hline WS 0' & 5 & 38 & 35 & 36.5 & $3.65 E+06$ \\
\hline WS 0' & 6 & 1 & 3 & 2 & $2.00 \mathrm{E}+06$ \\
\hline $1^{\prime}$ & 4 & 46 & 41 & 43.5 & $4.35 E+05$ \\
\hline $2^{\prime}$ & 4 & 15 & 23 & 19 & $1.90 \mathrm{E}+05$ \\
\hline $3^{\prime}$ & 3 & 105 & 99 & 102 & $1.02 E+05$ \\
\hline $4^{\prime}$ & 3 & 42 & 42 & 42 & $4.20 \mathrm{E}+04$ \\
\hline $5^{\prime}$ & 3 & 21 & 33 & 27 & $2.70 \mathrm{E}+04$ \\
\hline $7^{\prime}$ & 3 & 25 & 28 & 26.5 & $2.65 E+04$ \\
\hline $10^{\prime}$ & 3 & 30 & 26 & 28 & $2.80 E+04$ \\
\hline
\end{tabular}




\begin{tabular}{|c|c|c|c|c|c|c|c|c|c|}
\hline $\begin{array}{l}\text { Date of } \\
\text { Expt: }\end{array}$ & \multicolumn{9}{|l|}{$7 / 1 / 2005$} \\
\hline Expt \#: & \multicolumn{9}{|l|}{63} \\
\hline Date read: & \multicolumn{9}{|c|}{$7 / 2 / 2005$} \\
\hline Purpose: & \multicolumn{9}{|c|}{ Dosage Response Curve for E. coli } \\
\hline WS: & \multicolumn{9}{|c|}{ E.coli grown in 5:1 IO:NB for 5 days, spun, washed $\mathrm{X} 3$ and resuspended in $5: 1 \mathrm{IO} / \mathrm{diH} 2 \mathrm{O}$} \\
\hline \multirow[b]{2}{*}{ Conc.(mg/l) } & \multirow[b]{2}{*}{$\begin{array}{l}\text { time } \\
(\min )\end{array}$} & \multirow[b]{2}{*}{ dilution } & \multirow{2}{*}{$\begin{array}{l}\mathrm{lg} \\
\text { wls } \\
\text { pos }\end{array}$} & \multirow{2}{*}{$\begin{array}{l}\text { sm } \\
\text { wls } \\
\text { pos }\end{array}$} & \multirow[b]{2}{*}{$\begin{array}{l}\text { MPN/ } \\
100 \mathrm{ml}\end{array}$} & \multirow[b]{2}{*}{$\mathrm{MPN} / \mathrm{ml}$} & \multirow[b]{2}{*}{$\begin{array}{l}\text { calc } \\
\text { MPN/ml }\end{array}$} & \multirow[b]{2}{*}{$C^{*} T$} & \multirow[b]{2}{*}{$\begin{array}{l}\text { log } \\
\text { redctn. }\end{array}$} \\
\hline & & & & & & & & & \\
\hline 0 & 0 & 5 & 49 & 36 & 866.4 & 866400 & 866400 & 0 & $\mathrm{~N} / \mathrm{A}$ \\
\hline 0 & 0 & 7 & 7 & 0 & 7.5 & 750000 & 750000 & 0 & $\mathrm{~N} / \mathrm{A}$ \\
\hline 0 & 0 & 9 & 1 & 0 & 1 & 10000000 & 10000000 & 0 & $\mathrm{~N} / \mathrm{A}$ \\
\hline 0.25 & 1 & 1 & 49 & 48 & $>2419.6$ & $>24.2$ & $>24.2$ & 0.25 & $\mathrm{~N} / \mathrm{A}$ \\
\hline 0.25 & 1 & 3 & 49 & 47 & 2419.5 & 24195 & 24195 & 0.25 & 1.52 \\
\hline 0.25 & 1 & 5 & 21 & 6 & 34.5 & 34500 & 34500 & 0.25 & 1.37 \\
\hline 0.25 & 2 & 3 & 49 & 46 & 1986.3 & 19863 & 19863 & 0.5 & 1.61 \\
\hline 0.25 & 2 & 5 & 15 & 4 & 22.3 & 22300 & 22300 & 0.5 & 1.56 \\
\hline 0.25 & 3 & 1 & 49 & 48 & $>2419.6$ & $>24.2$ & $>24.2$ & 0.75 & $\mathrm{~N} / \mathrm{A}$ \\
\hline 0.25 & 3 & 3 & 49 & 43 & 1413.6 & 14136 & 14136 & 0.75 & 1.76 \\
\hline 0.25 & 3 & 5 & 16 & 2 & 21.3 & 21300 & 21300 & 0.75 & 1.58 \\
\hline 0.25 & 5 & 3 & 49 & 44 & 1553.1 & 15531 & 15531 & 1.25 & 1.72 \\
\hline 0.25 & 5 & 5 & 14 & 0 & 16.1 & 16100 & 16100 & 1.25 & 1.70 \\
\hline 0.75 & 1 & 1 & 49 & 48 & $>2419.6$ & $>24.2$ & $>24.2$ & 0.75 & $\mathrm{~N} / \mathrm{A}$ \\
\hline 0.75 & 1 & 4 & 38 & 3 & 72.7 & 7270 & 7270 & 0.75 & 2.05 \\
\hline 0.75 & 2 & 1 & 49 & 48 & $>2419.6$ & $>24.2$ & $>24.2$ & 1.5 & $\mathrm{~N} / \mathrm{A}$ \\
\hline 0.75 & 2 & 4 & 27 & 2 & 40.4 & 4040 & 4040 & 1.5 & 2.30 \\
\hline 0.75 & 3 & 1 & 49 & 48 & $>2419.6$ & $>24.2$ & $>24.2$ & 2.25 & $\mathrm{~N} / \mathrm{A}$ \\
\hline 0.75 & 3 & 4 & 16 & 2 & 21.3 & 2130 & 2130 & 2.25 & 2.58 \\
\hline 0.75 & 5 & 1 & 49 & 48 & $>2419.6$ & $>24.2$ & $>24.2$ & 3.75 & $\mathrm{~N} / \mathrm{A}$ \\
\hline 0.75 & 5 & 4 & 10 & 1 & 12.1 & 1210 & 1210 & 3.75 & 2.82 \\
\hline 1.5 & 1 & 1 & 49 & 48 & $>2419.6$ & $>24.2$ & $>24.2$ & 1.5 & $\mathrm{~N} / \mathrm{A}$ \\
\hline 1.5 & 1 & 4 & 15 & 1 & 18.7 & 1870 & 1870 & 1.5 & 2.64 \\
\hline 1.5 & 2 & 1 & 49 & 45 & 1732.9 & 173.29 & 173.29 & 3 & 3.67 \\
\hline 1.5 & 2 & 3 & 12 & 1 & 14.6 & 146 & 146 & 3 & 3.74 \\
\hline 1.5 & 3 & 1 & 49 & 44 & 1553.1 & 155.31 & 155.31 & 4.5 & 3.72 \\
\hline 1.5 & 3 & 3 & 9 & 0 & 9.8 & 98 & 98 & 4.5 & 3.92 \\
\hline 1.5 & 5 & 1 & 49 & 37 & 920.8 & 92.08 & 92.08 & 7.5 & 3.94 \\
\hline 1.5 & 5 & 3 & 6 & 0 & 6.3 & 63 & 63 & 7.5 & 4.11 \\
\hline
\end{tabular}




\begin{tabular}{|c|c|c|c|c|c|c|c|c|c|}
\hline $\begin{array}{l}\text { Date of } \\
\text { Expt: }\end{array}$ & \multicolumn{9}{|l|}{$7 / 6 / 2005$} \\
\hline Expt \#: & \multicolumn{9}{|l|}{64} \\
\hline Date read: & \multicolumn{9}{|l|}{$7 / 7 / 2005$} \\
\hline Purpose: & \multicolumn{9}{|c|}{ Dosage Response Curve for E. coli } \\
\hline WS: & \multicolumn{9}{|c|}{$\begin{array}{l}\text { E.coli grown in 5:1 IO:NB for } 5 \text { days, then spun, washed } X 3 \text { and resuspended in 5:1 } \\
\text { IO/diH2O }\end{array}$} \\
\hline \multirow[b]{2}{*}{ Conc.(mg/l) } & \multirow[b]{2}{*}{$\begin{array}{l}\text { time } \\
(\min )\end{array}$} & \multirow[b]{2}{*}{ dilution } & \multirow{2}{*}{$\begin{array}{l}\text { lg } \\
\text { wls } \\
\text { pos }\end{array}$} & \multirow{2}{*}{$\begin{array}{l}\text { sm } \\
\text { wls } \\
\text { pos }\end{array}$} & \multirow[b]{2}{*}{$\begin{array}{l}\text { MPN/ } \\
100 \mathrm{ml}\end{array}$} & \multirow[b]{2}{*}{$\mathrm{MPN} / \mathrm{ml}$} & \multirow[b]{2}{*}{$\begin{array}{l}\text { calc } \\
\mathrm{MPN} / \mathrm{ml}\end{array}$} & \multirow[b]{2}{*}{$C^{*} T$} & \multirow[b]{2}{*}{$\begin{array}{l}\log \\
\text { redctn. }\end{array}$} \\
\hline & & & & & & & & & \\
\hline 0 & 0 & 3 & 49 & 48 & $>2419.6$ & $>24.2$ & $>24.2$ & 0 & $\mathrm{~N} / \mathrm{A}$ \\
\hline 0 & 0 & 5 & 25 & 3 & 37.9 & 37900 & 37900 & 0 & $\mathrm{~N} / \mathrm{A}$ \\
\hline 0 & 0 & 7 & 0 & 0 & 0 & 0 & 100000 & 0 & $\mathrm{~N} / \mathrm{A}$ \\
\hline 0.25 & 1 & 1 & 49 & 48 & $>2419.6$ & $>24.2$ & $>24.2$ & 0.25 & $\mathrm{~N} / \mathrm{A}$ \\
\hline 0.25 & 1 & 3 & 45 & 30 & 250.4 & 2504 & 2504 & 0.25 & 1.18 \\
\hline 0.25 & 1 & 5 & 6 & 0 & 6.3 & 6300 & 6300 & 0.25 & 0.78 \\
\hline 0.25 & 2 & 3 & 44 & 26 & 199.3 & 1993 & 1993 & 0.5 & 1.28 \\
\hline 0.25 & 2 & 5 & 4 & 1 & 5.2 & 5200 & 5200 & 0.5 & 0.86 \\
\hline 0.25 & 3 & 1 & 49 & 47 & 2419.6 & 241.96 & 241.96 & 0.75 & 2.19 \\
\hline 0.25 & 3 & 3 & 44 & 23 & 182.9 & 1829 & 1829 & 0.75 & 1.32 \\
\hline 0.25 & 3 & 5 & 3 & 0 & 3.1 & 3100 & 3100 & 0.75 & 1.09 \\
\hline 0.25 & 5 & 3 & 41 & 19 & 132 & 1320 & 1320 & 1.25 & 1.46 \\
\hline 0.25 & 5 & 5 & 0 & 0 & 0 & 0 & 1000 & 1.25 & 1.58 \\
\hline 0.75 & 1 & 1 & 49 & 47 & 2419.6 & 241.96 & 241.96 & 0.75 & 2.19 \\
\hline 0.75 & 1 & 4 & 3 & 0 & 3.1 & 310 & 310 & 0.75 & 2.09 \\
\hline 0.75 & 2 & 1 & 49 & 42 & 1299.65 & 129.97 & 129.97 & 1.5 & 2.46 \\
\hline 0.75 & 2 & 4 & 3 & 0 & 3.1 & 310 & 310 & 1.5 & 2.09 \\
\hline 0.75 & 3 & 1 & 49 & 36 & 866.4 & 86.64 & 86.64 & 2.25 & 2.64 \\
\hline 0.75 & 3 & 4 & 1 & 0 & 1 & 100 & 100 & 2.25 & 2.58 \\
\hline 0.75 & 5 & 1 & 48 & 21 & 285.1 & 28.51 & 28.51 & 3.75 & 3.12 \\
\hline 0.75 & 5 & 4 & 1 & 0 & 1 & 100 & 100 & 3.75 & 2.58 \\
\hline 1.5 & 1 & 1 & 40 & 9 & 95.9 & 9.59 & 9.59 & 1.5 & 3.60 \\
\hline 1.5 & 1 & 3 & 3 & 0 & 3.1 & 31 & 31 & 1.5 & 3.09 \\
\hline 1.5 & 2 & 1 & 26 & 1 & 36.9 & 3.69 & 3.69 & 3 & 4.01 \\
\hline 1.5 & 2 & 3 & 3 & 0 & 3.1 & 31 & 31 & 3 & 3.09 \\
\hline 1.5 & 3 & 1 & 14 & 1 & 17.3 & 1.73 & 1.73 & 4.5 & 4.34 \\
\hline 1.5 & 3 & 3 & 1 & 0 & 1 & 10 & 10 & 4.5 & 3.58 \\
\hline 1.5 & 5 & 1 & 5 & 0 & 5.1 & 0.51 & 0.51 & 7.5 & 4.87 \\
\hline 1.5 & 5 & 3 & 0 & 0 & 0 & 0 & 10 & 7.5 & 3.58 \\
\hline
\end{tabular}




\begin{tabular}{|c|c|c|c|c|c|c|c|c|c|}
\hline $\begin{array}{l}\text { Date of } \\
\text { Expt: }\end{array}$ & \multicolumn{9}{|l|}{$7 / 6 / 2005$} \\
\hline Expt \#: & \multicolumn{9}{|l|}{65} \\
\hline Date read: & \multicolumn{9}{|l|}{$7 / 7 / 2005$} \\
\hline Purpose: & \multicolumn{9}{|c|}{ Dosage Response Curve for E. coli } \\
\hline WS: & \multicolumn{9}{|c|}{$\begin{array}{l}\text { E.coli grown in } 5: 1 \mathrm{IO}: \mathrm{NB} \text { for } 5 \text { days, then spun, washed } \mathrm{X} 3 \text { and resuspended in } 5: 1 \\
1 \mathrm{O} / \mathrm{diH} 2 \mathrm{O}\end{array}$} \\
\hline \multirow[b]{2}{*}{ Conc.(mg/l) } & \multirow[b]{2}{*}{$\begin{array}{l}\text { time } \\
(\min )\end{array}$} & \multirow[b]{2}{*}{ dilution } & \multirow{2}{*}{$\begin{array}{l}\text { lg } \\
\text { wls } \\
\text { pos }\end{array}$} & \multirow{2}{*}{$\begin{array}{l}\text { sm } \\
\text { wls } \\
\text { pos }\end{array}$} & \multirow[b]{2}{*}{$\begin{array}{l}\text { MPN/ } \\
100 \mathrm{ml}\end{array}$} & \multirow[b]{2}{*}{$\mathrm{MPN} / \mathrm{ml}$} & \multirow[b]{2}{*}{$\begin{array}{l}\text { calc } \\
\mathrm{MPN} / \mathrm{ml}\end{array}$} & \multirow[b]{2}{*}{$C^{*} T$} & \multirow[b]{2}{*}{$\begin{array}{l}\log \\
\text { redctn. }\end{array}$} \\
\hline & & & & & & & & & \\
\hline 0 & 0 & 3 & 49 & 48 & $>2419.6$ & $>24.2$ & $>24.2$ & 0 & $\mathrm{~N} / \mathrm{A}$ \\
\hline 0 & 0 & 5 & 25 & 3 & 37.9 & 37900 & 37900 & 0 & $\mathrm{~N} / \mathrm{A}$ \\
\hline 0 & 0 & 7 & 1 & 0 & 1 & 100000 & 100000 & 0 & $\mathrm{~N} / \mathrm{A}$ \\
\hline 0.25 & 1 & 1 & 49 & 48 & $>2419.6$ & $>24.2$ & $>24.2$ & 0.25 & $\mathrm{~N} / \mathrm{A}$ \\
\hline 0.25 & 1 & 3 & 48 & 36 & 574.8 & 5748 & 5748 & 0.25 & 3.24 \\
\hline 0.25 & 1 & 5 & 11 & 0 & 12.2 & 12200 & 12200 & 0.25 & 2.91 \\
\hline 0.25 & 2 & 3 & 48 & 30 & 436 & 4360 & 4360 & 0.5 & 3.36 \\
\hline 0.25 & 2 & 5 & 10 & 0 & 11 & 11000 & 11000 & 0.5 & 2.96 \\
\hline 0.25 & 3 & 1 & 49 & 48 & $>2419.6$ & $>24.2$ & $>24.2$ & 0.75 & $\mathrm{~N} / \mathrm{A}$ \\
\hline 0.25 & 3 & 3 & 46 & 25 & 241.5 & 2415 & 2415 & 0.75 & 3.62 \\
\hline 0.25 & 3 & 5 & 4 & 1 & 5.2 & 5200 & 5200 & 0.75 & 3.28 \\
\hline 0.25 & 5 & 3 & 45 & 16 & 162.4 & 1624 & 1624 & 1.25 & 3.79 \\
\hline 0.25 & 5 & 5 & 2 & 0 & 2 & 2000 & 2000 & 1.25 & 3.70 \\
\hline 0.75 & 1 & 1 & 49 & 48 & $>2419.6$ & $>24.2$ & $>24.2$ & 0.75 & $\mathrm{~N} / \mathrm{A}$ \\
\hline 0.75 & 1 & 4 & 4 & 0 & 4.1 & 410 & 410 & 0.75 & 4.39 \\
\hline 0.75 & 2 & 1 & 49 & 35 & 816.4 & 81.64 & 81.64 & 1.5 & 5.09 \\
\hline 0.75 & 2 & 4 & 2 & 0 & 2 & 200 & 200 & 1.5 & 4.70 \\
\hline 0.75 & 3 & 1 & 49 & 29 & 579.4 & 57.94 & 57.94 & 2.25 & 5.24 \\
\hline 0.75 & 3 & 4 & 2 & 0 & 2 & 200 & 200 & 2.25 & 4.70 \\
\hline 0.75 & 5 & 1 & 48 & 24 & 328.2 & 32.82 & 32.82 & 3.75 & 5.48 \\
\hline 0.75 & 5 & 4 & 2 & 0 & 2 & 200 & 200 & 3.75 & 4.70 \\
\hline 1.5 & 1 & 1 & 36 & 4 & 67.7 & 6.77 & 6.77 & 1.5 & 6.17 \\
\hline 1.5 & 1 & 3 & 3 & 0 & 3.1 & 31 & 31 & 1.5 & 5.51 \\
\hline 1.5 & 2 & 1 & 22 & 3 & 32.3 & 3.23 & 3.23 & 3 & 6.49 \\
\hline 1.5 & 2 & 3 & 1 & 0 & 1 & 10 & 10 & 3 & 6.00 \\
\hline 1.5 & 3 & 1 & 7 & 2 & 9.6 & 0.96 & 0.96 & 4.5 & 7.02 \\
\hline 1.5 & 3 & 3 & 0 & 0 & 0 & 0 & 1000 & 4.5 & 4.00 \\
\hline 1.5 & 5 & 1 & 2 & 0 & 2 & 0.2 & 0.2 & 7.5 & 7.70 \\
\hline 1.5 & 5 & 3 & 0 & 0 & 0 & 0 & 1000 & 7.5 & 4.00 \\
\hline
\end{tabular}




\begin{tabular}{|c|c|c|c|c|c|c|c|c|c|}
\hline $\begin{array}{l}\text { Date of } \\
\text { Expt: }\end{array}$ & \multicolumn{9}{|c|}{$8 / 17 / 2005$} \\
\hline Expt \#: & \multicolumn{9}{|c|}{79} \\
\hline Date read: & \multicolumn{9}{|c|}{$8 / 18 / 2005$} \\
\hline Purpose: & \multicolumn{9}{|c|}{ Dosage Response Curve for E. coli } \\
\hline WS: & \multicolumn{9}{|c|}{ E.coli grown in 5:1 IO:NB for 3 days, spun, washed $\mathrm{X} 3$ and resuspended in 5:1 IO/diH2O } \\
\hline \multirow[b]{2}{*}{ Conc.(mg/l) } & \multirow[b]{2}{*}{$\begin{array}{l}\text { time } \\
(\min )\end{array}$} & \multirow[b]{2}{*}{ dilution } & \multirow{2}{*}{$\begin{array}{l}\text { lg } \\
\text { wls } \\
\text { pos }\end{array}$} & \multirow{2}{*}{$\begin{array}{l}\text { sm } \\
\text { wls } \\
\text { pos }\end{array}$} & \multirow[b]{2}{*}{$\begin{array}{l}\text { MPN/ } \\
100 \mathrm{ml}\end{array}$} & \multirow[b]{2}{*}{$\mathrm{MPN} / \mathrm{ml}$} & \multirow[b]{2}{*}{$\begin{array}{l}\text { calc } \\
\text { MPN/ml }\end{array}$} & \multirow[b]{2}{*}{$\mathrm{C}^{*} \mathrm{~T}$} & \multirow[b]{2}{*}{$\begin{array}{l}\text { log } \\
\text { redctn. }\end{array}$} \\
\hline & & & & & & & & & \\
\hline 0 & 0 & nd & nd & nd & nd & nd & nd & 0 & $\mathrm{~N} / \mathrm{A}$ \\
\hline 0 & 0 & 7 & 45 & 15 & 157.6 & 15760000 & 15760000 & 0 & $\mathrm{~N} / \mathrm{A}$ \\
\hline 0 & 0 & 5 & 49 & 48 & $>2419.6$ & $>24.2$ & $>24.2$ & 0 & $\mathrm{~N} / \mathrm{A}$ \\
\hline 0.25 & 1 & 3 & 49 & 48 & $>2419.6$ & $>24.2$ & $>24.2$ & 0.25 & $\mathrm{~N} / \mathrm{A}$ \\
\hline 0.25 & 1 & 6 & 49 & 28 & 547.5 & 5475000 & 5475000 & 0.25 & 0.46 \\
\hline 0.25 & 2 & 3 & 49 & 48 & $>2419.6$ & $>24.2$ & $>24.2$ & 0.5 & $\mathrm{~N} / \mathrm{A}$ \\
\hline 0.25 & 2 & 6 & 48 & 19 & 260.3 & 2603000 & 2603000 & 0.5 & 0.78 \\
\hline 0.25 & 3 & 3 & 49 & 48 & $>2419.6$ & $>24.2$ & $>24.2$ & 0.75 & $\mathrm{~N} / \mathrm{A}$ \\
\hline 0.25 & 3 & 6 & 48 & 15 & 218.7 & 2187000 & 2187000 & 0.75 & 0.86 \\
\hline 0.25 & 5 & 3 & 49 & 48 & $>2419.6$ & $>24.2$ & $>24.2$ & 1.25 & $\mathrm{~N} / \mathrm{A}$ \\
\hline 0.25 & 5 & 6 & 48 & 10 & 178.9 & 1789000 & 1789000 & 1.25 & 0.94 \\
\hline 0.25 & 15 & 3 & 49 & 48 & $>2419.6$ & $>24.2$ & $>24.2$ & 3.75 & $\mathrm{~N} / \mathrm{A}$ \\
\hline 0.25 & 15 & 6 & 47 & 9 & 155.3 & 1553000 & 1553000 & 3.75 & 1.01 \\
\hline 0.25 & 30 & 3 & 49 & 48 & $>2419.6$ & $>24.2$ & $>24.2$ & 7.5 & $\mathrm{~N} / \mathrm{A}$ \\
\hline 0.25 & 30 & 5 & 49 & 22 & 387.3 & 387300 & 387300 & 7.5 & 1.61 \\
\hline 0.75 & 1 & 2 & 49 & 48 & $>2419.6$ & $>24.2$ & $>24.2$ & 0.75 & $\mathrm{~N} / \mathrm{A}$ \\
\hline 0.75 & 1 & 5 & 49 & 16 & 275.5 & 275500 & 275500 & 0.75 & 1.76 \\
\hline 0.75 & 2 & 2 & 49 & 48 & $>2419.6$ & $>24.2$ & $>24.2$ & 1.5 & $\mathrm{~N} / \mathrm{A}$ \\
\hline 0.75 & 2 & 5 & 46 & 1 & 109.8 & 109800 & 109800 & 1.5 & 2.16 \\
\hline 0.75 & 3 & 2 & 49 & 48 & $>2419.6$ & $>24.2$ & $>24.2$ & 2.25 & $\mathrm{~N} / \mathrm{A}$ \\
\hline 0.75 & 3 & 5 & 31 & 4 & 52.9 & 52900 & 52900 & 2.25 & 2.47 \\
\hline 0.75 & 5 & 2 & 49 & 48 & $>2419.6$ & $>24.2$ & $>24.2$ & 3.75 & $\mathrm{~N} / \mathrm{A}$ \\
\hline 0.75 & 5 & 5 & 20 & 0 & 24.9 & 24900 & 24900 & 3.75 & 2.80 \\
\hline 0.75 & 15 & 2 & 49 & 48 & $>2419.6$ & $>24.2$ & $>24.2$ & 11.25 & $\mathrm{~N} / \mathrm{A}$ \\
\hline 0.75 & 15 & 4 & 25 & 3 & 37.9 & 3790 & 3790 & 11.25 & 3.62 \\
\hline 0.75 & 30 & 2 & 49 & 48 & $>2419.6$ & $>24.2$ & $>24.2$ & 22.5 & $\mathrm{~N} / \mathrm{A}$ \\
\hline 0.75 & 30 & 4 & 15 & 0 & 17.5 & 1750 & 1750 & 22.5 & 3.95 \\
\hline 1.5 & 1 & 4 & 49 & 19 & 325.5 & 32550 & 32550 & 1.5 & 2.69 \\
\hline 1.5 & 2 & 4 & 45 & 17 & 167.4 & 16740 & 16740 & 3 & 2.97 \\
\hline 1.5 & 3 & 2 & 49 & 48 & $>2419.6$ & $>24.2$ & $>24.2$ & 4.5 & $\mathrm{~N} / \mathrm{A}$ \\
\hline 1.5 & 3 & 4 & 40 & 3 & 80.9 & 8090 & 8090 & 4.5 & 3.29 \\
\hline 1.5 & 5 & 4 & 23 & 1 & 31.3 & 3130 & 3130 & 7.5 & 3.70 \\
\hline 1.5 & 15 & 3 & 47 & 4 & 130.9 & 1309 & 1309 & 22.5 & 4.08 \\
\hline 1.5 & 30 & 3 & 10 & 1 & 12.1 & 121 & 121 & 45 & 5.11 \\
\hline 3 & 1 & 3 & 49 & 31 & 648.8 & 6488 & 6488 & 3 & 3.39 \\
\hline 3 & 2 & 3 & 49 & 13 & 235.9 & 2359 & 2359 & 6 & 3.82 \\
\hline 3 & 3 & 3 & 42 & 9 & 107.6 & 1076 & 1076 & 9 & 4.17 \\
\hline 3 & 5 & 3 & 39 & 2 & 74.4 & 744 & 744 & 15 & 4.33 \\
\hline 3 & 15 & 3 & 10 & 1 & 12.1 & 121 & 121 & 75 & 5.11 \\
\hline 5 & 1 & 3 & 43 & 9 & 114.5 & 1145 & 1145 & 5 & 4.14 \\
\hline 5 & 2 & 3 & 14 & 1 & 17.3 & 173 & 173 & 10 & 4.96 \\
\hline 5 & 3 & 3 & 5 & 0 & 5.2 & 52 & 52 & 15 & 5.48 \\
\hline 5 & 5 & 1 & 18 & 7 & 30.7 & 3.07 & 3.07 & 0 & 6.71 \\
\hline
\end{tabular}




\begin{tabular}{|c|c|c|c|c|c|c|c|c|c|}
\hline $\begin{array}{l}\text { Date of } \\
\text { Expt: }\end{array}$ & \multicolumn{9}{|c|}{$8 / 17 / 2005$} \\
\hline Expt \#: & \multicolumn{9}{|c|}{80} \\
\hline Date read: & \multicolumn{9}{|c|}{$8 / 18 / 2005$} \\
\hline Purpose: & \multicolumn{9}{|c|}{ Dosage Response Curve for E. coli } \\
\hline WS: & \multicolumn{9}{|c|}{ E.coli grown in 5:1 IO:NB for 3 days, spun, washed $\mathrm{X} 3$ and resuspended in 5:1 IO/diH2O } \\
\hline \multirow[b]{2}{*}{ Conc.(mg/l) } & \multirow[b]{2}{*}{$\begin{array}{l}\text { time } \\
(\min )\end{array}$} & \multirow[b]{2}{*}{ dilution } & \multirow{2}{*}{$\begin{array}{l}\mathrm{lg} \\
\text { wls } \\
\text { pos }\end{array}$} & \multirow{2}{*}{$\begin{array}{l}\text { sm } \\
\text { wls } \\
\text { pos }\end{array}$} & \multirow[b]{2}{*}{$\begin{array}{l}\text { MPN/ } \\
100 \mathrm{ml}\end{array}$} & \multirow[b]{2}{*}{$\mathrm{MPN} / \mathrm{ml}$} & \multirow[b]{2}{*}{$\begin{array}{l}\text { calc } \\
\text { MPN/ml }\end{array}$} & \multirow[b]{2}{*}{$C^{*} T$} & \multirow[b]{2}{*}{$\begin{array}{l}\text { log } \\
\text { redctn. }\end{array}$} \\
\hline & & & & & & & & & \\
\hline 0 & 0 & nd & nd & nd & nd & nd & nd & 0 & $\mathrm{~N} / \mathrm{A}$ \\
\hline 0 & 0 & 7 & 45 & 15 & 157.6 & 15760000 & 15760000 & 0 & $\mathrm{~N} / \mathrm{A}$ \\
\hline 0 & 0 & 5 & 49 & 48 & $>2419.6$ & $>24.2$ & $>24.2$ & 0 & $\mathrm{~N} / \mathrm{A}$ \\
\hline 0.25 & 1 & 3 & 49 & 48 & $>2419.6$ & $>24.2$ & $>24.2$ & 0.25 & $\mathrm{~N} / \mathrm{A}$ \\
\hline 0.25 & 1 & 6 & 49 & 29 & 579.4 & 5794000 & 5794000 & 0.25 & 0.43 \\
\hline 0.25 & 2 & 3 & 49 & 48 & $>2419.6$ & $>24.2$ & $>24.2$ & 0.5 & $\mathrm{~N} / \mathrm{A}$ \\
\hline 0.25 & 2 & 6 & 48 & 28 & 396.8 & 3968000 & 3968000 & 0.5 & 0.60 \\
\hline 0.25 & 3 & 3 & 49 & 48 & $>2419.6$ & $>24.2$ & $>24.2$ & 0.75 & $\mathrm{~N} / \mathrm{A}$ \\
\hline 0.25 & 3 & 6 & 49 & 15 & 261.3 & 2613000 & 2613000 & 0.75 & 0.78 \\
\hline 0.25 & 5 & 3 & 49 & 48 & $>2419.6$ & $>24.2$ & $>24.2$ & 1.25 & $\mathrm{~N} / \mathrm{A}$ \\
\hline 0.25 & 5 & 6 & 48 & 12 & 193.5 & 1935000 & 1935000 & 1.25 & 0.91 \\
\hline 0.25 & 15 & 3 & 49 & 48 & $>2419.6$ & $>24.2$ & $>24.2$ & 3.75 & $\mathrm{~N} / \mathrm{A}$ \\
\hline 0.25 & 15 & 6 & 47 & 7 & 145 & 1450000 & 1450000 & 3.75 & 1.04 \\
\hline 0.25 & 30 & 3 & 49 & 48 & $>2419.6$ & $>24.2$ & $>24.2$ & 7.5 & $\mathrm{~N} / \mathrm{A}$ \\
\hline 0.25 & 30 & 5 & 49 & 44 & 1553.1 & 1553100 & 1553100 & 7.5 & 1.01 \\
\hline 0.75 & 1 & 2 & 49 & 48 & $>2419.6$ & $>24.2$ & $>24.2$ & 0.75 & $\mathrm{~N} / \mathrm{A}$ \\
\hline 0.75 & 1 & 5 & 41 & 15 & 119.1 & 119100 & 119100 & 0.75 & 2.12 \\
\hline 0.75 & 2 & 2 & 49 & 48 & $>2419.6$ & $>24.2$ & $>24.2$ & 1.5 & $\mathrm{~N} / \mathrm{A}$ \\
\hline 0.75 & 2 & 5 & 18 & 0 & 21.8 & 21800 & 21800 & 1.5 & 2.86 \\
\hline 0.75 & 3 & 2 & 49 & 48 & $>2419.6$ & $>24.2$ & $>24.2$ & 2.25 & $\mathrm{~N} / \mathrm{A}$ \\
\hline 0.75 & 3 & 5 & 14 & 1 & 17.3 & 17300 & 17300 & 2.25 & 2.96 \\
\hline 0.75 & 5 & 2 & 49 & 48 & $>2419.6$ & $>24.2$ & $>24.2$ & 3.75 & $\mathrm{~N} / \mathrm{A}$ \\
\hline 0.75 & 5 & 5 & 10 & 1 & 12.1 & 12100 & 12100 & 3.75 & 3.11 \\
\hline 0.75 & 15 & 2 & 49 & 48 & $>2419.6$ & $>24.2$ & $>24.2$ & 11.25 & $\mathrm{~N} / \mathrm{A}$ \\
\hline 0.75 & 15 & 4 & 26 & 3 & 39.9 & 3990 & 3990 & 11.25 & 3.60 \\
\hline 0.75 & 30 & 2 & 49 & 48 & $>2419.6$ & $>24.2$ & $>24.2$ & 22.5 & $\mathrm{~N} / \mathrm{A}$ \\
\hline 0.75 & 30 & 4 & 22 & 2 & 30.9 & 3090 & 3090 & 22.5 & 3.71 \\
\hline 1.5 & 1 & 4 & 44 & 17 & 154.1 & 15410 & 15410 & 1.5 & 3.01 \\
\hline 1.5 & 2 & 4 & 27 & 2 & 40.4 & 4040 & 4040 & 3 & 3.59 \\
\hline 1.5 & 2 & 2 & 49 & 46 & 1986.3 & 1986.3 & 1986.3 & 3 & 3.90 \\
\hline 1.5 & 3 & 4 & 16 & 0 & 18.9 & 1890 & 1890 & 4.5 & 3.92 \\
\hline 1.5 & 5 & 3 & 46 & 8 & 137.6 & 1376 & 1376 & 7.5 & 4.06 \\
\hline 1.5 & 15 & 3 & 33 & 4 & 58.3 & 583 & 583 & 22.5 & 4.43 \\
\hline 1.5 & 30 & 3 & 28 & 1 & 41 & 410 & 410 & 45 & 4.58 \\
\hline 3 & 1 & 3 & 49 & 27 & 517.2 & 5172 & 5172 & 3 & 3.48 \\
\hline 3 & 2 & 3 & 36 & 11 & 82.3 & 823 & 823 & 6 & 4.28 \\
\hline 3 & 3 & 3 & 29 & 2 & 44.8 & 448 & 448 & 9 & 4.55 \\
\hline 3 & 5 & 1 & 49 & 32 & 686.7 & 68.67 & 68.67 & 15 & 5.36 \\
\hline 3 & 15 & 1 & 46 & 18 & 190.4 & 19.04 & 19.04 & 75 & 5.92 \\
\hline 5 & 1 & 3 & 43 & 9 & 114.5 & 1145 & 1145 & 5 & 4.14 \\
\hline 5 & 2 & 3 & 18 & 1 & 23.1 & 231 & 231 & 10 & 4.83 \\
\hline 5 & 3 & 3 & 7 & 0 & 7.5 & 75 & 75 & 15 & 5.32 \\
\hline 5 & 5 & 1 & 22 & 0 & 28.2 & 2.82 & 2.82 & 0 & 6.75 \\
\hline
\end{tabular}




\begin{tabular}{|c|c|c|c|c|c|c|c|c|}
\hline $\begin{array}{l}\text { Date of } \\
\text { Expt: }\end{array}$ & \multicolumn{8}{|c|}{$9 / 13 / 2005$} \\
\hline Expt \#: & \multicolumn{8}{|c|}{92} \\
\hline Date read: & \multicolumn{8}{|c|}{$9 / 14 / 2005$} \\
\hline Purpose: & \multicolumn{8}{|c|}{ Dosage Response Curve for E. coli } \\
\hline WS: & \multicolumn{8}{|c|}{ E.coli grown in 5:1 IO:NB for 5 days, spun, washed $\mathrm{X} 3$, \& resuspended in 5:1 IO/diH2O } \\
\hline \multirow[b]{2}{*}{ Conc.(mg/l) } & \multirow{2}{*}{$\begin{array}{l}\text { time } \\
(\min )\end{array}$} & & \multirow{2}{*}{$\begin{array}{l}\text { lg wls } \\
\text { pos }\end{array}$} & \multirow{2}{*}{$\begin{array}{l}\text { sm wls } \\
\text { pos }\end{array}$} & \multirow{2}{*}{$\begin{array}{l}\text { MPN/ } \\
100 \mathrm{ml}\end{array}$} & & \multirow{2}{*}{$\begin{array}{l}\text { calc } \\
\text { MPN/ml }\end{array}$} & \multirow{2}{*}{$\begin{array}{l}\text { log } \\
\text { redctn. }\end{array}$} \\
\hline & & dilution & & & & $\mathrm{MPN} / \mathrm{ml}$ & & \\
\hline 0 & 0 & 7 & 44 & 14 & 141.4 & 14140000 & 14140000 & N/A \\
\hline 0 & 0 & 5 & 49 & 48 & $>2419.6$ & $>24.2$ & $>24.2$ & $\mathrm{~N} / \mathrm{A}$ \\
\hline 0.75 & 1 & 3 & nd & nd & nd & nd & nd & nd \\
\hline 0.75 & 1 & 4 & 48 & 13 & 201.4 & 20140 & 20140 & 2.85 \\
\hline 0.75 & 2 & 3 & nd & nd & nd & nd & nd & nd \\
\hline 0.75 & 2 & 4 & 38 & 4 & 74.9 & 7490 & 7490 & 3.28 \\
\hline 0.75 & 3 & 3 & nd & nd & nd & nd & nd & nd \\
\hline 0.75 & 3 & 4 & 33 & 8 & 65.7 & 6570 & 6570 & 3.33 \\
\hline 0.75 & 5 & 3 & nd & nd & $>2419.6$ & $>24.2$ & $>24.2$ & N/A \\
\hline 0.75 & 5 & 4 & 20 & 3 & 28.8 & 2880 & 2880 & 3.69 \\
\hline 0.75 & 15 & 1 & nd & nd & nd & nd & nd & nd \\
\hline 0.75 & 15 & 3 & 48 & 20 & 272.3 & 2723 & 2723 & 3.72 \\
\hline 0.75 & 30 & 1 & nd & nd & nd & nd & nd & nd \\
\hline 0.75 & 30 & 3 & 44 & 8 & 118.7 & 1187 & 1187 & 4.08 \\
\hline 1.5 & 1 & 2 & nd & nd & nd & nd & nd & nd \\
\hline 1.5 & 1 & 4 & 46 & 9 & 142.1 & 14210 & 14210 & 3.00 \\
\hline 1.5 & 2 & 4 & 18 & 1 & 23.1 & 2310 & 2310 & 3.79 \\
\hline 1.5 & 3 & 3 & 29 & 8 & 54.5 & 545 & 545 & 4.41 \\
\hline 1.5 & 5 & 3 & 17 & 1 & 21.6 & 216 & 216 & 4.82 \\
\hline 1.5 & 15 & 3 & 7 & 2 & 9.6 & 96 & 96 & 5.17 \\
\hline 1.5 & 30 & 3 & 4 & 0 & 4.1 & 41 & 41 & 5.54 \\
\hline 3 & 1 & 3 & 48 & 16 & 275.5 & 2755 & 2755 & 3.71 \\
\hline 3 & 1 & 5 & nd & nd & nd & nd & nd & nd \\
\hline 3 & 2 & 3 & 35 & 7 & 70.3 & 703 & 703 & 4.30 \\
\hline 3 & 2 & 5 & nd & nd & nd & nd & nd & nd \\
\hline 3 & 3 & 2 & 46 & 11 & 151.5 & 151.5 & 151.5 & 4.97 \\
\hline 3 & 5 & 2 & 24 & 0 & 31.7 & 31.7 & 31.7 & 5.65 \\
\hline 3 & 15 & 2 & 5 & 1 & 6.3 & 6.3 & 6.3 & 6.35 \\
\hline 3 & 30 & 2 & 3 & 0 & 3.1 & 3.1 & 3.1 & 6.66 \\
\hline 4 & 1 & 3 & 42 & 9 & 107.6 & 1076 & 1076 & 4.12 \\
\hline 4 & 1 & 2 & nd & nd & nd & nd & nd & nd \\
\hline 4 & 2 & 2 & 46 & 14 & 167 & 167 & 167 & 4.93 \\
\hline 4 & 2 & 2 & nd & nd & nd & nd & nd & nd \\
\hline 4 & 3 & 2 & 33 & 10 & 69.5 & 69.5 & 69.5 & 5.31 \\
\hline 4 & 5 & 2 & 14 & 2 & 18.5 & 18.5 & 18.5 & 5.88 \\
\hline 4 & 15 & 2 & 4 & 0 & 4.1 & 4.1 & 4.1 & 6.54 \\
\hline 4 & 30 & 2 & nd & nd & nd & nd & nd & nd \\
\hline 5 & 1 & 2 & 48 & 15 & 218.7 & 218.7 & 218.7 & 4.81 \\
\hline 5 & 2 & 2 & 38 & 9 & 86.2 & 86.2 & 86.2 & 5.21 \\
\hline 5 & 3 & 2 & 19 & 5 & 29.8 & 29.8 & 29.8 & 5.68 \\
\hline 5 & 5 & 2 & 2 & 2 & 4.1 & 4.1 & 4.1 & 6.54 \\
\hline 5 & 15 & 1 & 5 & 0 & 5.2 & 0.52 & 0.52 & 7.43 \\
\hline
\end{tabular}




\begin{tabular}{|c|c|c|c|c|c|c|c|c|}
\hline \multirow{2}{*}{$\begin{array}{l}\text { Date of } \\
\text { Expt: } \\
\text { Expt \#: } \\
\text { Date read: } \\
\text { Purpose: } \\
\text { WS: } \\
\\
\text { Conc.(mg/l) }\end{array}$} & \multicolumn{8}{|c|}{$\begin{array}{l}\text { 9/13/2005 } \\
93 \\
9 / 14 / 2005 \\
\text { Dosage Response Curve for E. coli } \\
\text { E.coli grown in 5:1 IO:NB for } 5 \text { days,spun, washed X3 and resuspended in 5:1 } \\
\text { IO/diH2O }\end{array}$} \\
\hline & $\begin{array}{l}\text { time } \\
(\min )\end{array}$ & dilution & $\begin{array}{l}\text { lg wls } \\
\text { pos }\end{array}$ & $\begin{array}{l}\text { sm wls } \\
\text { pos }\end{array}$ & $\begin{array}{l}\text { MPN/ } \\
100 \mathrm{ml}\end{array}$ & MPN/ml & $\begin{array}{l}\text { calc } \\
\text { MPN/ml }\end{array}$ & $\begin{array}{l}\text { log } \\
\text { redctn. }\end{array}$ \\
\hline 0 & 0 & nd & nd & $\mathrm{nd}$ & $\mathrm{nd}$ & nd & nd & $N / A$ \\
\hline 0 & 0 & 7 & 44 & 14 & 141.4 & 14140000 & 14140000 & N/A \\
\hline 0 & 0 & 5 & 49 & 48 & $>2419.6$ & $>24.2$ & $>24.2$ & N/A \\
\hline 0.75 & 1 & 3 & 49 & 48 & $>2419.6$ & $>24.2$ & $>24.2$ & $\mathrm{~N} / \mathrm{A}$ \\
\hline 0.75 & 1 & 5 & 46 & 17 & 184.2 & 184200 & 184200 & 1.89 \\
\hline 0.75 & 2 & 3 & nd & nd & nd & nd & nd & nd \\
\hline 0.75 & 2 & 4 & 49 & 25 & 461.1 & 46110 & 46110 & 2.49 \\
\hline 0.75 & 3 & 3 & nd & nd & nd & nd & nd & nd \\
\hline 0.75 & 3 & 4 & 43 & 12 & 124.6 & 12460 & 12460 & 3.05 \\
\hline 0.75 & 5 & 3 & nd & nd & $>2419.6$ & $>24.2$ & $>24.2$ & N/A \\
\hline 0.75 & 5 & 4 & 30 & 6 & 53.7 & 5370 & 5370 & 3.42 \\
\hline 0.75 & 15 & 1 & nd & nd & nd & nd & nd & nd \\
\hline 0.75 & 15 & 3 & 43 & 8 & 111.2 & 1112 & 1112 & 4.10 \\
\hline 0.75 & 30 & 1 & nd & nd & nd & nd & nd & nd \\
\hline 0.75 & 30 & 3 & 42 & 7 & 101.7 & 1017 & 1017 & 4.14 \\
\hline 1.5 & 1 & 2 & nd & nd & nd & nd & nd & nd \\
\hline 1.5 & 1 & 4 & 31 & 7 & 58.1 & 5810 & 5810 & 3.39 \\
\hline 1.5 & 2 & 4 & 6 & 0 & 6.3 & 630 & 630 & 4.35 \\
\hline 1.5 & 3 & 3 & 28 & 3 & 44.1 & 441 & 441 & 4.51 \\
\hline 1.5 & 5 & 3 & 15 & 1 & 18.7 & 187 & 187 & 4.88 \\
\hline 1.5 & 15 & 3 & 5 & 0 & 5.2 & 52 & 52 & 5.43 \\
\hline 1.5 & 30 & 3 & 2 & 0 & 2 & 20 & 20 & 5.85 \\
\hline 3 & 1 & 3 & 30 & 2 & 47.1 & 471 & 471 & 4.48 \\
\hline 3 & 1 & 5 & nd & nd & nd & $\mathrm{nd}$ & nd & nd \\
\hline 3 & 2 & 3 & 20 & 0 & 24.9 & 249 & 249 & 4.75 \\
\hline 3 & 2 & 5 & nd & nd & nd & nd & nd & nd \\
\hline 3 & 3 & 2 & 37 & 6 & 75.1 & 75.1 & 75.1 & 5.27 \\
\hline 3 & 5 & 2 & 19 & 3 & 27.2 & 27.2 & 27.2 & 5.72 \\
\hline 3 & 15 & 2 & 5 & 1 & 6.3 & 6.3 & 6.3 & 6.35 \\
\hline 3 & 30 & 2 & 1 & 1 & 2 & 2 & 2 & 6.85 \\
\hline 4 & 1 & 3 & 21 & 2 & 29.2 & 292 & 292 & 4.69 \\
\hline 4 & 1 & 2 & nd & nd & nd & nd & nd & nd \\
\hline 4 & 2 & 3 & 5 & 0 & 5.2 & 52 & 52 & 5.43 \\
\hline 4 & 2 & 2 & nd & nd & nd & nd & nd & nd \\
\hline 4 & 3 & 2 & 16 & 1 & 20.1 & 20.1 & 20.1 & 5.85 \\
\hline 4 & 5 & 2 & 4 & 2 & 6.2 & 6.2 & 6.2 & 6.36 \\
\hline 4 & 15 & 2 & 2 & 0 & 2 & 2 & 2 & 6.85 \\
\hline 4 & 30 & 2 & nd & nd & nd & nd & nd & nd \\
\hline 5 & 1 & 2 & 44 & 9 & 122.3 & 122.3 & 122.3 & 5.06 \\
\hline 5 & 2 & 2 & 15 & 2 & 19.9 & 19.9 & 19.9 & 5.85 \\
\hline 5 & 3 & 2 & 5 & 0 & 5.2 & 5.2 & 5.2 & 6.43 \\
\hline 5 & 5 & 2 & 1 & 0 & 1 & 1 & 1 & 7.15 \\
\hline 5 & 15 & 1 & 4 & 0 & 4.1 & 0.41 & 0.41 & 7.54 \\
\hline
\end{tabular}




\section{E.2 Dosage Response Experiments for K. pneumoniae}

Expt. \#:

Date of Expt.:

Date HPC read:

Purpose:

WS:
31

$5 / 3 / 2005$

$5 / 6 / 2005$

Dosage response of $K$. pneumoniae to $5 \mathrm{mg} / \mathrm{l}$ ferrate

K. pneumoniae in IO:NB, $600 \mathrm{mls}$ as a $5: 1$ dilution, grown for 4 days on shaker table at RT, then spun and resuspended in 5:1 IO:dH2O

\begin{tabular}{|c|c|c|c|c|c|}
\hline \multicolumn{6}{|c|}{ Heterotrophic Plate Count } \\
\hline & & $\begin{array}{l}\text { Number of } \\
\text { Colonies }\end{array}$ & & & \\
\hline Specimen/QC & $\begin{array}{l}\text { Dilution } \\
\left(10^{\wedge}-n\right)\end{array}$ & Plate 1 & $\begin{array}{l}\text { Plat } \\
\text { e } 2\end{array}$ & $\begin{array}{l}\text { ave } \\
\text { coun } \\
t\end{array}$ & $\begin{array}{l}\text { Colony } \\
\text { Count }\end{array}$ \\
\hline QC open, hood & & 0 & & & 0 \\
\hline QC closed, hood & & 0 & & & 0 \\
\hline QC open, counter & & 3 & & & 3 \\
\hline dilution buffer & & 0 & & & 0 \\
\hline Instant Ocean & & nd & & & nd \\
\hline \multicolumn{6}{|c|}{$\begin{array}{l}\text { all specs. w/ferrate stopped w/TS; all } \\
\text { concs. are } 5 \mathrm{mg} / \mathrm{l}\end{array}$} \\
\hline & & & & & \\
\hline WS 0' & 6 & 34 & 38 & 36 & $\begin{array}{r}3.60 \mathrm{E}+0 \\
7\end{array}$ \\
\hline WS 0' & 7 & 1 & 4 & 2.5 & $\begin{array}{r}2.50 \mathrm{E}+0 \\
7\end{array}$ \\
\hline 5 mg/l, 15' & 1 & 58 & 57 & 57.5 & $\begin{array}{r}5.75 \mathrm{E}+0 \\
2\end{array}$ \\
\hline 5 mg/l, 15' & 2 & 13 & 8 & 10.5 & $\begin{array}{r}1.05 \mathrm{E}+0 \\
1\end{array}$ \\
\hline $5 \mathrm{mg} / \mathrm{l}, 60^{\prime}$ & 1 & cont & 0 & cont & $\mathrm{N} / \mathrm{A}$ \\
\hline 5 mg/l, 60' & $1,1 \mathrm{ml}$ & 0 & 0 & 0 & $\begin{array}{r}0.00 \mathrm{E}+0 \\
0\end{array}$ \\
\hline
\end{tabular}




\begin{tabular}{|l|l|}
\hline Expt. \#: & 33 \\
\hline Date of Expt.: & $5 / 3 / 2005$ \\
\hline Date HPC read: & $5 / 6 / 2005$ \\
\hline Purpose: & Dosage response of $K$. pneumoniae to $5 \mathrm{mg} / \mathrm{l}$ ferrate \\
\hline WS: & $\begin{array}{l}\text { K. pneumoniae in IO:NB, } 600 \text { mls as a } 5: 1 \text { dilution, grown for } 4 \text { days on shaker } \\
\text { table at RT, then spun and resuspended in 5:1 IO:dH2O }\end{array}$ \\
\hline
\end{tabular}

\begin{tabular}{|c|c|c|c|c|c|}
\hline \multicolumn{6}{|c|}{ Heterotrophic Plate Count } \\
\hline & & $\begin{array}{l}\text { Number of } \\
\text { Colonies }\end{array}$ & & & \\
\hline Specimen/QC & $\begin{array}{l}\text { Dilution } \\
\left(10^{\wedge}-n\right)\end{array}$ & Plate 1 & $\begin{array}{l}\text { Plate } \\
2\end{array}$ & $\begin{array}{l}\text { ave } \\
\text { coun } \\
t\end{array}$ & $\begin{array}{l}\text { Colony } \\
\text { Count }\end{array}$ \\
\hline QC open, hood & & 0 & & & 0 \\
\hline QC closed, hood & & 0 & & & 0 \\
\hline QC open, counter & & 1 & & & 1 \\
\hline dilution buffer & & nd & & & nd \\
\hline Instant Ocean & & nd & & & nd \\
\hline \multicolumn{6}{|l|}{$\begin{array}{l}\text { all specs. w/ferrate stopped w/TS; all } \\
\text { concs. are } 5 \mathrm{mg} / \mathrm{I}\end{array}$} \\
\hline & & & & & $310 \mathrm{~F}+0$ \\
\hline WS 0' & 6 & 29 & 33 & 31 & 7 \\
\hline WS 0' & 7 & 3 & 1 & 2 & $\begin{array}{r}2.00 \mathrm{E}+0 \\
7 \\
\end{array}$ \\
\hline $5 \mathrm{mg} / \mathrm{l}, 15^{\prime}$ & 1 & 4 & 6 & 5 & $\begin{array}{r}5.00 \mathrm{E}+0 \\
1\end{array}$ \\
\hline 5 mg/l, 15' & $1,1 \mathrm{ml}$ & 48 & $\begin{array}{r}\text { awc } \\
g\end{array}$ & 48 & $\begin{array}{r}4.80 \mathrm{E}+0 \\
1\end{array}$ \\
\hline 5 mg/l, 60' & 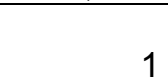 & 0 & 0 & 0 & $\begin{array}{r}0.00 \mathrm{E}+0 \\
0\end{array}$ \\
\hline $5 \mathrm{mg} / \mathrm{l}, 60^{\prime}$ & $1,1 \mathrm{ml}$ & 0 & 0 & 0 & $\begin{array}{r}0.00 \mathrm{E}+0 \\
0\end{array}$ \\
\hline
\end{tabular}




\begin{tabular}{|l|l|}
\hline Expt. \#: & 35 \\
\hline Date of Expt.: & $5 / 3 / 2005$ \\
\hline Date HPC read: & $5 / 6 / 2005$ \\
\hline Purpose: & Dosage response of $K$. pneumoniae to $2 \mathrm{mg} / \mathrm{l}$ ferrate \\
\hline WS: & $\begin{array}{l}\text { K. pneumoniae in IO:NB, } 600 \text { mls as a } 5: 1 \text { dilution, grown for } 4 \text { days on shaker } \\
\text { table at RT, then spun and resuspended in 5:1 IO:dH2O }\end{array}$ \\
\hline
\end{tabular}

\begin{tabular}{|c|c|c|c|c|c|}
\hline \multicolumn{6}{|c|}{ Heterotrophic Plate Count } \\
\hline & & $\begin{array}{l}\text { Number of } \\
\text { Colonies }\end{array}$ & & & \\
\hline Specimen/QC & $\begin{array}{l}\text { Dilution } \\
\left(10^{\wedge}-n\right)\end{array}$ & Plate 1 & $\begin{array}{l}\text { Plat } \\
\text { e } 2\end{array}$ & $\begin{array}{l}\text { ave } \\
\text { coun } \\
t\end{array}$ & $\begin{array}{l}\text { Colony } \\
\text { Count }\end{array}$ \\
\hline QC open, hood & & 0 & & & 0 \\
\hline QC closed, hood & & nd & & & nd \\
\hline QC open, counter & & nd & & & nd \\
\hline dilution buffer & & 0 & & & 0 \\
\hline Instant Ocean & & nd & & & nd \\
\hline \multicolumn{6}{|l|}{$\begin{array}{l}\text { all specs. w/ferrate stopped w/TS; all } \\
\text { concs. are } 5 \mathrm{mg} / \mathrm{l}\end{array}$} \\
\hline & & & & & \\
\hline WS 0' & 6 & 35 & 30 & 32.5 & $\begin{array}{r}3.25 \mathrm{E}+0 \\
7\end{array}$ \\
\hline WS 0' & 7 & 2 & 5 & 3.5 & $\begin{array}{r}3.50 \mathrm{E}+0 \\
7\end{array}$ \\
\hline $5 \mathrm{mg} / \mathrm{l}, 15^{\prime}$ & 1 & 0 & 0 & 0 & $\begin{array}{r}0.00 \mathrm{E}+0 \\
0\end{array}$ \\
\hline $5 \mathrm{mg} / \mathrm{l}, 15^{\prime}$ & $1,1 \mathrm{ml}$ & 2 & 5 & 3.5 & $\begin{array}{r}3.50 \mathrm{E}+0 \\
0\end{array}$ \\
\hline $5 \mathrm{mg} / \mathrm{l}, 60^{\prime}$ & 1 & 0 & 0 & 0 & $\begin{array}{r}0.00 \mathrm{E}+0 \\
0\end{array}$ \\
\hline $5 \mathrm{mg} / \mathrm{l}, 60^{\prime}$ & $1,1 \mathrm{ml}$ & 0 & 0 & 0 & $\begin{array}{r}0.00 \mathrm{E}+0 \\
0\end{array}$ \\
\hline
\end{tabular}




\begin{tabular}{|l|l|}
\hline Expt. \#: & 60 \\
\hline Date of Expt.: & $6 / 27 / 2005$ \\
\hline $\begin{array}{l}\text { Date HPC } \\
\text { read: }\end{array}$ & $7 / 1 / 2005$ \\
\hline Purpose: & Short contact times of $0.5 \mathrm{mg} / \mathrm{l}$ ferrate on K. pneumoniae \\
\hline WS: & $\begin{array}{l}\text { K. pneumoniae in IO:NB, } 600 \text { mls as a } 5: 1 \text { dilution, grown for } 4 \text { days on shaker } \\
\text { table at RT, then spun and resuspended in } 5: 1 \text { IO:dH2O }\end{array}$ \\
\hline
\end{tabular}

\begin{tabular}{|c|c|c|c|c|c|}
\hline \multicolumn{6}{|c|}{ Heterotrophic Plate Count } \\
\hline & & \multicolumn{2}{|c|}{$\begin{array}{c}\text { Number of } \\
\text { Colonies }\end{array}$} & & \\
\hline Specimen/QC & Dilution $\left(10^{\wedge}-n\right)$ & $\begin{array}{r}\text { Plate } \\
1\end{array}$ & $\begin{array}{r}\text { Plate } \\
2\end{array}$ & Ave. Count & Colony Count \\
\hline QC open, hood & & 1 & & & 1 \\
\hline QC closed, hood & & nd & & & nd \\
\hline QC open, counter & & 1 & & & 1 \\
\hline dilution buffer & & 0 & & & 0 \\
\hline Instant Ocean & & nd & & & nd \\
\hline \multicolumn{6}{|c|}{ all specs. w/ferrate stopped w/TS; all concs. are $0.5 \mathrm{mg} / \mathrm{I}$} \\
\hline & & & & & \\
\hline WS 0' & 4 & 87 & 80 & 83.5 & $8.35 \mathrm{E}+05$ \\
\hline WS 0' & 5 & 12 & 10 & 11 & 1.10E+06 \\
\hline $1^{\prime}$ & 4 & 38 & 41 & 39.5 & $3.95 \mathrm{E}+05$ \\
\hline $2^{\prime}$ & 4 & 18 & 27 & 22.5 & $2.25 \mathrm{E}+05$ \\
\hline $3^{\prime}$ & 3 & 140 & 129 & 134.5 & $1.35 \mathrm{E}+05$ \\
\hline $4^{\prime}$ & 3 & 77 & 79 & 78 & $7.80 \mathrm{E}+04$ \\
\hline $5^{\prime}$ & 3 & 58 & 33 & 45.5 & $4.55 \mathrm{E}+04$ \\
\hline $7^{\prime}$ & 3 & 24 & 30 & 27 & $2.70 \mathrm{E}+04$ \\
\hline $10^{\prime}$ & 2 & 208 & 246 & 227 & $2.27 E+04$ \\
\hline
\end{tabular}




\begin{tabular}{|c|c|c|c|c|c|c|c|c|}
\hline $\begin{array}{l}\text { Date of } \\
\text { Expt: }\end{array}$ & \multicolumn{8}{|l|}{ 9/1/2005 } \\
\hline Expt \#: & \multicolumn{8}{|l|}{86} \\
\hline Date read: & \multicolumn{8}{|c|}{$9 / 2 / 2005$} \\
\hline Purpose: & \multicolumn{8}{|c|}{ Dosage Response Curve for $K$. pneumoniae } \\
\hline WS: & \multicolumn{8}{|c|}{$\begin{array}{l}\text { K. pneumoniae grown in } 5: 1 \mathrm{IO} \text { :NB for } 3 \text { days, spun, washed } \mathrm{X} 3 \text {, and resuspended in } \\
5: 1 \mathrm{IO} / \mathrm{diH} 2 \mathrm{O}\end{array}$} \\
\hline \multirow[b]{2}{*}{ Conc.(mg/l) } & \multirow{2}{*}{$\begin{array}{l}\text { time } \\
(\min )\end{array}$} & \multirow[b]{2}{*}{ dilution } & \multirow{2}{*}{$\begin{array}{l}\lg \text { wls } \\
\text { pos }\end{array}$} & \multirow{2}{*}{$\begin{array}{l}\text { sm wls } \\
\text { pos }\end{array}$} & \multirow{2}{*}{$\begin{array}{l}\text { MPN/ } \\
100 \mathrm{ml}\end{array}$} & \multirow[b]{2}{*}{$\mathrm{MPN} / \mathrm{ml}$} & \multirow{2}{*}{$\begin{array}{l}\text { calc } \\
\mathrm{MPN} / \mathrm{ml}\end{array}$} & \multirow{2}{*}{$\begin{array}{l}\text { log } \\
\text { redctn. }\end{array}$} \\
\hline & & & & & & & & \\
\hline 0 & 0 & 3 & 49 & 48 & nd & nd & nd & $\mathrm{N} / \mathrm{A}$ \\
\hline 0 & 0 & 7 & 32 & 7 & 60.9 & 6090000 & 6090000 & $\mathrm{~N} / \mathrm{A}$ \\
\hline 0 & 0 & 5 & 49 & 48 & $>2419.6$ & $>24.2$ & $>24.2$ & $\mathrm{~N} / \mathrm{A}$ \\
\hline 0.75 & 1 & 3 & 49 & 48 & $>2419.6$ & $>24.2$ & $>24.2$ & $\mathrm{~N} / \mathrm{A}$ \\
\hline 0.75 & 1 & 6 & 47 & 24 & 270 & 2700000 & 2700000 & 0.35 \\
\hline 0.75 & 2 & 3 & 49 & 48 & $>2419.6$ & $>24.2$ & $>24.2$ & $\mathrm{~N} / \mathrm{A}$ \\
\hline 0.75 & 2 & 6 & 43 & 16 & 139.1 & 1391000 & 1391000 & 0.64 \\
\hline 0.75 & 3 & 3 & 49 & 48 & $>2419.6$ & $>24.2$ & $>24.2$ & $\mathrm{~N} / \mathrm{A}$ \\
\hline 0.75 & 3 & 6 & 38 & 7 & 81.6 & 816000 & 816000 & 0.87 \\
\hline 0.75 & 5 & 3 & 49 & 48 & $>2419.6$ & $>24.2$ & $>24.2$ & $\mathrm{~N} / \mathrm{A}$ \\
\hline 0.75 & 5 & 6 & 17 & 2 & 22.8 & 228000 & 228000 & 1.43 \\
\hline 0.75 & 15 & 2 & 49 & 48 & $>2419.6$ & $>24.2$ & $>24.2$ & $\mathrm{~N} / \mathrm{A}$ \\
\hline 0.75 & 15 & 5 & 45 & 16 & 162.4 & 162400 & 162400 & 1.57 \\
\hline 0.75 & 30 & 2 & 49 & 48 & $>2419.6$ & $>24.2$ & $>24.2$ & $\mathrm{~N} / \mathrm{A}$ \\
\hline 0.75 & 30 & 5 & 42 & 17 & 133.6 & 133600 & 133600 & 1.66 \\
\hline 1.5 & 1 & 2 & 49 & 48 & $>2419.6$ & $>24.2$ & $>24.2$ & $\mathrm{~N} / \mathrm{A}$ \\
\hline 1.5 & 1 & 4 & 49 & 42 & 1299.7 & 129970 & 129970 & 1.67 \\
\hline 1.5 & 2 & 2 & 49 & 48 & $>2419.6$ & $>24.2$ & $>24.2$ & $\mathrm{~N} / \mathrm{A}$ \\
\hline 1.5 & 2 & 5 & 22 & 2 & 30.9 & 30900 & 30900 & 2.29 \\
\hline 1.5 & 3 & 2 & 49 & 48 & $>2419.6$ & $>24.2$ & $>24.2$ & $\mathrm{~N} / \mathrm{A}$ \\
\hline 1.5 & 3 & 4 & 48 & 17 & 238.2 & 23820 & 23820 & 2.41 \\
\hline 1.5 & 5 & 2 & 49 & 48 & $>2419.6$ & $>24.2$ & $>24.2$ & $\mathrm{~N} / \mathrm{A}$ \\
\hline 1.5 & 5 & 5 & 9 & 0 & 9.8 & 9800 & 9800 & 2.79 \\
\hline 1.5 & 15 & 2 & 49 & 48 & $>2419.6$ & $>24.2$ & $>24.2$ & $\mathrm{~N} / \mathrm{A}$ \\
\hline 1.5 & 15 & 4 & 34 & 11 & 74.8 & 7480 & 7480 & 2.91 \\
\hline 1.5 & 30 & 2 & 49 & 48 & $>2419.6$ & $>24.2$ & $>24.2$ & $\mathrm{~N} / \mathrm{A}$ \\
\hline 1.5 & 30 & 4 & 23 & 5 & 36.8 & 3680 & 3680 & 3.22 \\
\hline 3 & 1 & 4 & 35 & 4 & 64.4 & 6440 & 6440 & 2.98 \\
\hline 3 & 2 & 2 & 49 & 29 & 579.4 & 579.4 & 579.4 & 4.02 \\
\hline 3 & 3 & 2 & 49 & 17 & 290.9 & 290.9 & 290.9 & 4.32 \\
\hline 3 & 3 & 4 & 3 & 0 & 3.1 & 310 & 310 & 4.29 \\
\hline 3 & 5 & 2 & 44 & 19 & 163.1 & 163.1 & 163.1 & 4.57 \\
\hline 3 & 15 & 1 & 46 & 33 & 319.9 & 31.99 & 31.99 & 5.28 \\
\hline 3 & 30 & 1 & 39 & 16 & 109 & 10.9 & 10.9 & 5.75 \\
\hline 4 & 1 & 3 & 28 & 4 & 45.7 & 457 & 457 & 4.12 \\
\hline 4 & 2 & 1 & 49 & 37 & 920.8 & 92.08 & 92.08 & 4.82 \\
\hline 4 & 3 & 1 & 46 & 28 & 268.2 & 26.82 & 26.82 & 5.36 \\
\hline 4 & 5 & 1 & 43 & 15 & 135.4 & 13.54 & 13.54 & 5.65 \\
\hline 4 & 15 & 1 & 21 & 2 & 29.2 & 2.92 & 2.92 & 6.32 \\
\hline 5 & 1 & 1 & 43 & 15 & 135.4 & 13.54 & 13.54 & 5.65 \\
\hline 5 & 2 & 1 & 27 & 3 & 42 & 4.2 & 4.2 & 6.16 \\
\hline 5 & 3 & 1 & 18 & 1 & 23.1 & 2.31 & 2.31 & 6.42 \\
\hline 5 & 5 & 1 & 9 & 0 & 9.8 & 0.98 & 0.98 & 6.79 \\
\hline 5 & 15 & 1 & 3 & 1 & 4.1 & 0.41 & 0.41 & 7.17 \\
\hline
\end{tabular}




\begin{tabular}{|c|c|c|c|c|c|c|c|c|}
\hline $\begin{array}{l}\text { Date of } \\
\text { Expt: }\end{array}$ & \multicolumn{8}{|l|}{$9 / 1 / 2005$} \\
\hline Expt \#: & \multicolumn{8}{|l|}{87} \\
\hline Date read: & \multicolumn{8}{|c|}{$9 / 2 / 2005$} \\
\hline Purpose: & \multicolumn{8}{|c|}{ Dosage Response Curve for K. pneumoniae } \\
\hline WS: & \multicolumn{8}{|c|}{$\begin{array}{l}\text { K. pneumoniae grown in } 5: 1 \mathrm{IO} \text { :NB for } 3 \text { days, spun, washed } \mathrm{X} 3 \text {, and resuspended in } \\
5: 1 \mathrm{IO} / \mathrm{diH} 2 \mathrm{O}\end{array}$} \\
\hline \multirow[b]{2}{*}{ Conc.(mg/l) } & \multirow{2}{*}{$\begin{array}{l}\text { time } \\
(\min )\end{array}$} & \multirow[b]{2}{*}{ dilution } & \multirow{2}{*}{$\begin{array}{l}\lg \text { wls } \\
\text { pos }\end{array}$} & \multirow{2}{*}{$\begin{array}{l}\text { sm wls } \\
\text { pos }\end{array}$} & \multirow{2}{*}{$\begin{array}{l}\text { MPN/ } \\
100 \mathrm{ml}\end{array}$} & \multirow[b]{2}{*}{ MPN/ml } & \multirow{2}{*}{$\begin{array}{l}\text { calc } \\
\mathrm{MPN} / \mathrm{ml}\end{array}$} & \multirow{2}{*}{$\begin{array}{l}\text { log } \\
\text { redctn. }\end{array}$} \\
\hline & & & & & & & & \\
\hline 0 & 0 & 3 & 49 & 48 & nd & nd & nd & $\mathrm{N} / \mathrm{A}$ \\
\hline 0 & 0 & 7 & 32 & 7 & 60.9 & 6090000 & 6090000 & $\mathrm{~N} / \mathrm{A}$ \\
\hline 0 & 0 & 5 & 49 & 48 & $>2419.6$ & $>24.2$ & $>24.2$ & $\mathrm{~N} / \mathrm{A}$ \\
\hline 0.75 & 1 & 3 & 49 & 48 & $>2419.6$ & $>24.2$ & $>24.2$ & $\mathrm{~N} / \mathrm{A}$ \\
\hline 0.75 & 1 & 6 & 47 & 23 & 259.5 & 2595000 & 2595000 & 0.37 \\
\hline 0.75 & 2 & 3 & 49 & 48 & $>2419.6$ & $>24.2$ & $>24.2$ & $\mathrm{~N} / \mathrm{A}$ \\
\hline 0.75 & 2 & 6 & 41 & 16 & 122.2 & 1222000 & 1222000 & 0.70 \\
\hline 0.75 & 3 & 3 & 49 & 48 & $>2419.6$ & $>24.2$ & $>24.2$ & $\mathrm{~N} / \mathrm{A}$ \\
\hline 0.75 & 3 & 6 & 32 & 7 & 60.9 & 609000 & 609000 & 1.00 \\
\hline 0.75 & 5 & 3 & 49 & 48 & $>2419.6$ & $>24.2$ & $>24.2$ & $\mathrm{~N} / \mathrm{A}$ \\
\hline 0.75 & 5 & 5 & 47 & 15 & 191.8 & 191800 & 191800 & 1.50 \\
\hline 0.75 & 15 & 2 & 49 & 48 & $>2419.6$ & $>24.2$ & $>24.2$ & $\mathrm{~N} / \mathrm{A}$ \\
\hline 0.75 & 15 & 5 & 43 & 7 & 108.1 & 108100 & 108100 & 1.75 \\
\hline 0.75 & 30 & 2 & 49 & 48 & $>2419.6$ & $>24.2$ & $>24.2$ & $\mathrm{~N} / \mathrm{A}$ \\
\hline 0.75 & 30 & 4 & 49 & 33 & 727 & 72700 & 72700 & 1.92 \\
\hline 1.5 & 1 & 2 & 49 & 48 & $>2419.6$ & $>24.2$ & $>24.2$ & $\mathrm{~N} / \mathrm{A}$ \\
\hline 1.5 & 1 & 4 & 49 & 44 & 1553.1 & 155310 & 155310 & 1.59 \\
\hline 1.5 & 2 & 2 & 49 & 48 & $>2419.6$ & $>24.2$ & $>24.2$ & $\mathrm{~N} / \mathrm{A}$ \\
\hline 1.5 & 2 & 4 & 49 & 37 & 920.8 & 92080 & 92080 & 1.82 \\
\hline 1.5 & 3 & 2 & 49 & 48 & $>2419.6$ & $>24.2$ & $>24.2$ & $\mathrm{~N} / \mathrm{A}$ \\
\hline 1.5 & 3 & 4 & 49 & 25 & 461.1 & 46110 & 46110 & 2.12 \\
\hline 1.5 & 5 & 2 & 49 & 48 & $>2419.6$ & $>24.2$ & $>24.2$ & $\mathrm{~N} / \mathrm{A}$ \\
\hline 1.5 & 5 & 4 & 49 & 18 & 307.6 & 30760 & 30760 & 2.30 \\
\hline 1.5 & 15 & 2 & 49 & 48 & $>2419.6$ & $>24.2$ & $>24.2$ & $\mathrm{~N} / \mathrm{A}$ \\
\hline 1.5 & 15 & 4 & 30 & 5 & 52 & 5200 & 5200 & 3.07 \\
\hline 1.5 & 30 & 2 & 49 & 48 & $>2419.6$ & $>24.2$ & $>24.2$ & $\mathrm{~N} / \mathrm{A}$ \\
\hline 1.5 & 30 & 4 & 29 & 6 & 51.2 & 5120 & 5120 & 3.08 \\
\hline 3 & 1 & 4 & 33 & 4 & 58.3 & 5830 & 5830 & 3.02 \\
\hline 3 & 2 & 4 & 23 & 0 & 29.9 & 2990 & 2990 & 3.31 \\
\hline 3 & 3 & 2 & 49 & 48 & $>2419.6$ & $>24.2$ & $>24.2$ & $\mathrm{~N} / \mathrm{A}$ \\
\hline 3 & 3 & 4 & 14 & 1 & 17.3 & 1730 & 1730 & 3.55 \\
\hline 3 & 5 & 4 & 8 & 1 & 9.7 & 970 & 970 & 3.80 \\
\hline 3 & 15 & 3 & 9 & 1 & 10.9 & 109 & 109 & 4.75 \\
\hline 3 & 30 & 3 & 1 & 1 & 2 & 20 & 20 & 5.48 \\
\hline 4 & 1 & 3 & 42 & 14 & 123.4 & 1234 & 1234 & 3.69 \\
\hline 4 & 2 & 3 & 27 & 4 & 43.5 & 435 & 435 & 4.15 \\
\hline 4 & 3 & 3 & 6 & 1 & 7.4 & 74 & 74 & 4.92 \\
\hline 4 & 5 & 1 & 44 & 31 & 230 & 23 & 23 & 5.42 \\
\hline 4 & 15 & 1 & 41 & 13 & 113 & 11.3 & 11.3 & 5.73 \\
\hline 5 & 1 & 1 & 49 & 33 & 727 & 72.7 & 72.7 & 4.92 \\
\hline 5 & 2 & 1 & 46 & 22 & 217.8 & 21.78 & 21.78 & 5.45 \\
\hline 5 & 3 & 1 & 40 & 14 & 109.5 & 10.95 & 10.95 & 5.75 \\
\hline 5 & 5 & 1 & 15 & 6 & 24.7 & 2.47 & 2.47 & 6.39 \\
\hline 5 & 15 & 1 & 12 & 0 & 13.5 & 1.35 & 1.35 & 6.65 \\
\hline
\end{tabular}




\begin{tabular}{|c|c|c|c|c|c|c|c|c|}
\hline $\begin{array}{l}\text { Date of } \\
\text { Expt: }\end{array}$ & \multicolumn{8}{|l|}{$9 / 6 / 2005$} \\
\hline Expt \#: & \multicolumn{8}{|l|}{88} \\
\hline Date read: & \multicolumn{8}{|c|}{$9 / 7 / 2005$} \\
\hline Purpose: & \multicolumn{8}{|c|}{ Dosage Response Curve for K. pneumoniae } \\
\hline WS: & \multicolumn{8}{|c|}{$\begin{array}{l}\text { K. pneumoniae grown in 5:1 IO:NB for } 3 \text { days, spun, washed } \mathrm{X} 3 \text {, and resuspended in } \\
5: 1 \mathrm{IO} / \mathrm{diH} 2 \mathrm{O}\end{array}$} \\
\hline Conc.(mg/l) & $\begin{array}{l}\text { time } \\
(\min )\end{array}$ & dilution & $\begin{array}{l}\lg \text { wls } \\
\text { pos }\end{array}$ & $\begin{array}{l}\text { sm wls } \\
\text { pos }\end{array}$ & $\begin{array}{l}\text { MPN/ } \\
100 \mathrm{ml}\end{array}$ & $\mathrm{MPN} / \mathrm{ml}$ & $\begin{array}{l}\text { calc } \\
\mathrm{MPN} / \mathrm{ml}\end{array}$ & $\begin{array}{l}\text { log } \\
\text { redctn. }\end{array}$ \\
\hline 0 & 0 & 3 & 49 & 48 & nd & nd & nd & $\mathrm{N} / \mathrm{A}$ \\
\hline 0 & 0 & 7 & 48 & 23 & 313 & 31300000 & 31300000 & $\mathrm{~N} / \mathrm{A}$ \\
\hline 0 & 0 & 5 & 49 & 48 & $>2419.6$ & $>24.2$ & $>24.2$ & $\mathrm{~N} / \mathrm{A}$ \\
\hline 0.75 & 1 & 3 & nd & nd & nd & nd & nd & nd \\
\hline 0.75 & 1 & 6 & 49 & 36 & 866.4 & 8664000 & 8664000 & 0.56 \\
\hline 0.75 & 2 & 3 & nd & nd & nd & nd & nd & nd \\
\hline 0.75 & 2 & 6 & 48 & 15 & 218.7 & 2187000 & 2187000 & 1.16 \\
\hline 0.75 & 3 & 3 & nd & nd & nd & nd & nd & nd \\
\hline 0.75 & 3 & 6 & 25 & 3 & 37.9 & 379000 & 379000 & 1.92 \\
\hline 0.75 & 5 & 3 & nd & nd & nd & $\mathrm{nd}$ & $\mathrm{nd}$ & nd \\
\hline 0.75 & 5 & 6 & 6 & 1 & 7.4 & 74000 & 74000 & 2.63 \\
\hline 0.75 & 15 & 2 & nd & nd & nd & nd & nd & nd \\
\hline 0.75 & 15 & 6 & 4 & 0 & 4.1 & 41000 & 41000 & 2.88 \\
\hline 0.75 & 30 & 6 & leakd & leakd & leaked & nd & nd & nd \\
\hline 0.75 & 30 & 3 & 49 & 46 & 1986.3 & 19863 & 19863 & 3.20 \\
\hline 1.5 & 1 & 2 & nd & nd & nd & nd & nd & nd \\
\hline 1.5 & 1 & 4 & 49 & 46 & 1986.3 & 198630 & 198630 & 2.20 \\
\hline 1.5 & 2 & 2 & nd & nd & nd & nd & nd & nd \\
\hline 1.5 & 2 & 4 & 49 & 36 & 866.4 & 86640 & 86640 & 2.56 \\
\hline 1.5 & 3 & 2 & nd & nd & nd & nd & nd & nd \\
\hline 1.5 & 3 & 4 & 48 & 29 & 416 & 41600 & 41600 & 2.88 \\
\hline 1.5 & 5 & 2 & nd & nd & nd & nd & nd & nd \\
\hline 1.5 & 5 & 4 & 46 & 22 & 217.8 & 21780 & 21780 & 3.16 \\
\hline 1.5 & 15 & 2 & nd & nd & nd & nd & nd & $\mathrm{nd}$ \\
\hline 1.5 & 15 & 4 & 43 & 17 & 143 & 14300 & 14300 & 3.34 \\
\hline 1.5 & 30 & 2 & nd & nd & nd & nd & nd & nd \\
\hline 1.5 & 30 & 3 & 49 & 40 & 1119.9 & 11199 & 11199 & 3.45 \\
\hline 3 & 1 & 3 & 49 & 31 & 648.8 & 6488 & 6488 & 3.68 \\
\hline 3 & 2 & 3 & 48 & 25 & 344.1 & 3441 & 3441 & 3.96 \\
\hline 3 & 3 & 4 & nd & nd & nd & nd & nd & nd \\
\hline 3 & 3 & 2 & 49 & 43 & 1413.6 & 1413.6 & 1413.6 & 4.35 \\
\hline 3 & 5 & 2 & 48 & 30 & 436 & 436 & 436 & 4.86 \\
\hline 3 & 15 & 2 & 47 & 13 & 178.5 & 178.5 & 178.5 & 5.24 \\
\hline 3 & 30 & 2 & 35 & 12 & 80.5 & 80.5 & 80.5 & 5.59 \\
\hline 4 & 1 & 3 & 48 & 24 & 328.2 & 3282 & 3282 & 3.98 \\
\hline 4 & 2 & 2 & 49 & 34 & 770.1 & 770.1 & 770.1 & 4.61 \\
\hline 4 & 3 & 2 & 45 & 19 & 178 & 178 & 178 & 5.25 \\
\hline 4 & 5 & 2 & 33 & 8 & 65.7 & 65.7 & 65.7 & 5.68 \\
\hline 4 & 15 & 1 & 32 & 2 & 52.1 & 5.21 & 5.21 & 6.78 \\
\hline 5 & 1 & 2 & 48 & 13 & 201.4 & 201.4 & 201.4 & 5.19 \\
\hline 5 & 2 & 1 & 49 & 20 & 344.8 & 34.48 & 34.48 & 5.96 \\
\hline 5 & 3 & 1 & 32 & 13 & 71.9 & 7.19 & 7.19 & 6.64 \\
\hline 5 & 5 & 1 & 4 & 2 & 6.2 & 0.62 & 0.62 & 7.70 \\
\hline 5 & 15 & 1 & 2 & 0 & 2 & 0.2 & 0.2 & 8.19 \\
\hline
\end{tabular}




\begin{tabular}{|c|c|c|c|c|c|c|c|c|}
\hline $\begin{array}{l}\text { Date of } \\
\text { Expt: }\end{array}$ & \multicolumn{8}{|l|}{$9 / 6 / 2005$} \\
\hline Expt \#: & \multicolumn{8}{|l|}{89} \\
\hline Date read: & \multicolumn{8}{|l|}{$9 / 7 / 2005$} \\
\hline Purpose: & \multicolumn{8}{|c|}{ Dosage Response Curve for K. pneumoniae } \\
\hline WS: & \multicolumn{8}{|c|}{$\begin{array}{l}\text { K. pneumoniae grown in 5:1 IO:NB for } 3 \text { days, spun, washed } \mathrm{X} 3 \text {, and resuspended in } \\
5: 1 \mathrm{IO} / \mathrm{diH} 2 \mathrm{O}\end{array}$} \\
\hline Conc.(mg/l) & $\begin{array}{l}\text { time } \\
(\min )\end{array}$ & dilution & $\begin{array}{l}\lg \text { wls } \\
\text { pos }\end{array}$ & $\begin{array}{l}\text { sm wls } \\
\text { pos }\end{array}$ & $\begin{array}{l}\text { MPN/ } \\
100 \mathrm{ml}\end{array}$ & $\mathrm{MPN} / \mathrm{ml}$ & $\begin{array}{l}\text { calc } \\
\mathrm{MPN} / \mathrm{ml}\end{array}$ & $\begin{array}{l}\text { log } \\
\text { redctn. }\end{array}$ \\
\hline 0 & 0 & 3 & 49 & 48 & nd & nd & nd & $\mathrm{N} / \mathrm{A}$ \\
\hline 0 & 0 & 7 & 48 & 23 & 313 & 31300000 & 31300000 & $\mathrm{~N} / \mathrm{A}$ \\
\hline 0 & 0 & 5 & 49 & 48 & $>2419.6$ & $>24.2$ & $>24.2$ & $\mathrm{~N} / \mathrm{A}$ \\
\hline 0.75 & 1 & 3 & nd & nd & nd & nd & nd & nd \\
\hline 0.75 & 1 & 6 & 47 & 25 & 280.9 & 2809000 & 2809000 & 1.05 \\
\hline 0.75 & 2 & 3 & nd & nd & nd & nd & nd & nd \\
\hline 0.75 & 2 & 6 & 43 & 16 & 139.1 & 1391000 & 1391000 & 1.35 \\
\hline 0.75 & 3 & 3 & nd & nd & nd & nd & nd & nd \\
\hline 0.75 & 3 & 6 & 28 & 4 & 45.7 & 457000 & 457000 & 1.84 \\
\hline 0.75 & 5 & 3 & nd & nd & nd & nd & $\mathrm{nd}$ & nd \\
\hline 0.75 & 5 & 6 & 17 & 0 & 20.3 & 203000 & 203000 & 2.19 \\
\hline 0.75 & 15 & 2 & nd & nd & nd & $\mathrm{nd}$ & $\mathrm{nd}$ & nd \\
\hline 0.75 & 15 & 6 & 10 & 1 & 12.1 & 121000 & 121000 & 2.41 \\
\hline 0.75 & 30 & 6 & 8 & 0 & 8.6 & 86000 & 86000 & 2.56 \\
\hline 0.75 & 30 & 3 & 49 & 46 & 1986.3 & 19863 & 19863 & 3.20 \\
\hline 1.5 & 1 & 2 & nd & nd & nd & $\mathrm{nd}$ & nd & nd \\
\hline 1.5 & 1 & 4 & 49 & 46 & 1986.3 & 198630 & 198630 & 2.20 \\
\hline 1.5 & 2 & 2 & nd & nd & nd & $\mathrm{nd}$ & nd & nd \\
\hline 1.5 & 2 & 4 & 49 & 34 & 770.1 & 77010 & 77010 & 2.61 \\
\hline 1.5 & 3 & 2 & nd & nd & nd & nd & nd & nd \\
\hline 1.5 & 3 & 4 & 49 & 25 & 461.1 & 46110 & 46110 & 2.83 \\
\hline 1.5 & 5 & 2 & nd & nd & nd & nd & nd & nd \\
\hline 1.5 & 5 & 4 & 46 & 22 & 217.8 & 21780 & 21780 & 3.16 \\
\hline 1.5 & 15 & 2 & nd & nd & nd & $\mathrm{nd}$ & $\mathrm{nd}$ & $\mathrm{nd}$ \\
\hline 1.5 & 15 & 4 & 47 & 14 & 185 & 18500 & 18500 & 3.23 \\
\hline 1.5 & 30 & 2 & nd & nd & nd & nd & nd & nd \\
\hline 1.5 & 30 & 3 & 49 & 37 & 920.8 & 9208 & 9208 & 3.53 \\
\hline 3 & 1 & 3 & 49 & 36 & 866.4 & 8664 & 8664 & 3.56 \\
\hline 3 & 2 & 3 & 46 & 24 & 233.3 & 2333 & 2333 & 4.13 \\
\hline 3 & 3 & 4 & nd & nd & nd & nd & nd & $\mathrm{nd}$ \\
\hline 3 & 3 & 2 & 49 & 33 & 727 & 727 & 727 & 4.63 \\
\hline 3 & 5 & 2 & 47 & 25 & 280.9 & 280.9 & 280.9 & 5.05 \\
\hline 3 & 15 & 2 & 40 & 4 & 83.3 & 83.3 & 83.3 & 5.57 \\
\hline 3 & 30 & 2 & 19 & 1 & 24.6 & 24.6 & 24.6 & 6.10 \\
\hline 4 & 1 & 3 & 47 & 18 & 214.2 & 2142 & 2142 & 4.16 \\
\hline 4 & 2 & 3 & 36 & 3 & 65.7 & 657 & 657 & 4.68 \\
\hline 4 & 3 & 2 & 49 & 16 & 275.5 & 275.5 & 275.5 & 5.06 \\
\hline 4 & 5 & 2 & 35 & 6 & 68.3 & 68.3 & 68.3 & 5.66 \\
\hline 4 & 15 & 1 & 37 & 8 & 79.8 & 7.98 & 7.98 & 6.59 \\
\hline 5 & 1 & 2 & 49 & 11 & 214.3 & 214.3 & 214.3 & 5.16 \\
\hline 5 & 2 & 1 & 49 & 34 & 770.1 & 77.01 & 77.01 & 5.61 \\
\hline 5 & 3 & 1 & 45 & 9 & 131.4 & 13.14 & 13.14 & 6.38 \\
\hline 5 & 5 & 1 & 2 & 0 & 2 & 0.2 & 0.2 & 8.19 \\
\hline 5 & 15 & 1 & 0 & 0 & 0 & 0 & 0.1 & 8.50 \\
\hline
\end{tabular}




\section{E.3 Dosage Response Experiments for Enterococci}

\begin{tabular}{|c|c|c|c|c|c|c|c|c|}
\hline WS (27-29): & \multicolumn{8}{|c|}{$\begin{array}{l}\text { Enterococcus faecilis and faecium grown in } 5: 1 \mathrm{IO}: \mathrm{NB} \text { for } 5 \text { days, spun, washed, and } \\
\text { resuspended in } 5: 1 \mathrm{IO} / \mathrm{diH} 2 \mathrm{O}\end{array}$} \\
\hline $\begin{array}{l}\text { Date of } \\
\text { Expts: }\end{array}$ & \multicolumn{8}{|l|}{$5 / 3 / 2005$} \\
\hline Date read: & \multicolumn{8}{|l|}{$5 / 5 / 2005$} \\
\hline & & & & \multirow[b]{2}{*}{$\begin{array}{l}\text { lg wells } \\
\text { pos }\end{array}$} & \multirow[b]{2}{*}{$\begin{array}{l}\text { sm wells } \\
\text { pos }\end{array}$} & & & \multirow[b]{2}{*}{$\begin{array}{l}\log \\
\text { redctn }\end{array}$} \\
\hline Condition & $\begin{array}{l}\text { conc } \\
(\mathrm{mg} / \mathrm{l})\end{array}$ & $\begin{array}{l}\text { time } \\
\text { (min) }\end{array}$ & dilution & & & MPN & MPN/ml & \\
\hline Expt. \#: & \multicolumn{8}{|l|}{27} \\
\hline WS & 0 & 0 & 6 & 44 & 10 & 125.9 & 1259000 & 0 \\
\hline $15 \mathrm{~min}$ & 5 & 15 & 1 & 12 & 1 & 14.6 & 1.46 & 5.9 \\
\hline $60 \mathrm{~min}$ & 5 & 60 & 1 & 0 & 0 & 0 & 0 & 6.1 \\
\hline Expt. \#: & \multicolumn{8}{|l|}{28} \\
\hline WS & & 0 & 7 & 10 & 1 & 12.1 & 1210000 & 0 \\
\hline $15 \mathrm{~min}$ & 5 & 15 & 1 & 9 & 2 & 11 & 1.1 & 6.0 \\
\hline $60 \mathrm{~min}$ & 5 & 60 & 1 & 0 & 0 & 0 & 0 & 6.1 \\
\hline Expt. \#: & \multicolumn{8}{|l|}{29} \\
\hline WS & 0 & 6 & 41 & 12 & 110 & 1100000 & 1100000 & 0 \\
\hline $15 \mathrm{~min}$ & 15 & 1 & 3 & 0 & 3.1 & 0.31 & 0.31 & 6.6 \\
\hline $60 \mathrm{~min}$ & 60 & 1 & 0 & 0 & 0 & 0 & 1 & 6.0 \\
\hline
\end{tabular}




\begin{tabular}{|c|c|c|c|c|c|c|c|c|}
\hline $\begin{array}{l}\text { Date of } \\
\text { Expt: }\end{array}$ & \multicolumn{8}{|l|}{$8 / 4 / 2005$} \\
\hline Expt \#: & \multicolumn{8}{|l|}{74} \\
\hline Date read: & \multicolumn{8}{|c|}{$8 / 5 / 2005$} \\
\hline Purpose: & \multicolumn{8}{|c|}{ Dosage Response Curve for Enterococci } \\
\hline WS: & \multicolumn{8}{|c|}{$\begin{array}{l}\text { Enterococci grown in } 5: 1 \mathrm{IO} \text { :NB for } 6 \text { days, spun, washed } \mathrm{X} 3 \text {, and resuspended in } \\
5: 1 \mathrm{IO} / \mathrm{diH} 2 \mathrm{O}\end{array}$} \\
\hline Conc.(mg/l) & $\begin{array}{l}\text { time } \\
(\min )\end{array}$ & dilution & $\begin{array}{l}\lg \text { wls } \\
\text { pos }\end{array}$ & $\begin{array}{l}\text { sm wls } \\
\text { pos }\end{array}$ & $\begin{array}{l}\text { MPN/ } \\
100 \mathrm{ml}\end{array}$ & $\mathrm{MPN} / \mathrm{ml}$ & $\begin{array}{l}\text { calc } \\
\text { MPN/ml }\end{array}$ & $\begin{array}{l}\log \\
\text { redctn. }\end{array}$ \\
\hline 0 & 0 & 3 & 49 & 48 & $>2419.6$ & $>2419.6$ & $>2419.6$ & $\mathrm{~N} / \mathrm{A}$ \\
\hline 0 & 0 & 5 & 46 & 24 & 233.3 & 233300 & 233300 & $\mathrm{~N} / \mathrm{A}$ \\
\hline 0 & 0 & 7 & 5 & 0 & 5 & 500000 & 500000 & $\mathrm{~N} / \mathrm{A}$ \\
\hline 0.25 & 1 & 2 & 49 & 48 & $>2419.6$ & $>2419.6$ & $>2419.6$ & $\mathrm{~N} / \mathrm{A}$ \\
\hline 0.25 & 1 & 4 & 49 & 46 & 1986.3 & 198630 & 198630 & 0.07 \\
\hline 0.25 & 2 & 2 & 49 & 48 & $>2419.6$ & $>2419.6$ & $>2419.6$ & $\mathrm{~N} / \mathrm{A}$ \\
\hline 0.25 & 2 & 4 & 49 & 43 & 1413.6 & 141360 & 141360 & 0.22 \\
\hline 0.25 & 3 & 2 & 49 & 48 & $>2419.6$ & $>2419.6$ & $>2419.6$ & $\mathrm{~N} / \mathrm{A}$ \\
\hline 0.25 & 3 & 4 & 49 & 40 & 1119.9 & 111990 & 111990 & 0.32 \\
\hline 0.25 & 5 & 2 & 49 & 48 & $>2419.6$ & $>2419.6$ & $>2419.6$ & $\mathrm{~N} / \mathrm{A}$ \\
\hline 0.25 & 5 & 4 & 49 & 34 & 770.1 & 77010 & 77010 & 0.48 \\
\hline 0.25 & 15 & 2 & 49 & 48 & $>2419.6$ & $>2419.6$ & $>2419.6$ & $\mathrm{~N} / \mathrm{A}$ \\
\hline 0.25 & 15 & 4 & 49 & 21 & 365.4 & 36540 & 36540 & 0.81 \\
\hline 0.25 & 30 & 3 & 49 & 47 & 2419.6 & 24196 & 24196 & 0.98 \\
\hline 0.75 & 1 & 2 & 49 & 48 & $>2419.6$ & $>2419.6$ & $>2419.6$ & $\mathrm{~N} / \mathrm{A}$ \\
\hline 0.75 & 1 & 4 & 47 & 27 & 304.4 & 30440 & 30440 & 0.88 \\
\hline 0.75 & 2 & 2 & 49 & 48 & $>2419.6$ & $>2419.6$ & $>2419.6$ & $\mathrm{~N} / \mathrm{A}$ \\
\hline 0.75 & 2 & 4 & 45 & 18 & 172.6 & 17260 & 17260 & 1.13 \\
\hline 0.75 & 3 & 2 & 49 & 48 & $>2419.6$ & $>2419.6$ & $>2419.6$ & $\mathrm{~N} / \mathrm{A}$ \\
\hline 0.75 & 3 & 4 & 42 & 8 & 104.6 & 10460 & 10460 & 1.35 \\
\hline 0.75 & 5 & 2 & 49 & 48 & $>2419.6$ & $>2419.6$ & $>2419.6$ & $\mathrm{~N} / \mathrm{A}$ \\
\hline 0.75 & 5 & 4 & 30 & 3 & 48.7 & 4870 & 4870 & 1.68 \\
\hline 0.75 & 15 & 1 & 49 & 48 & $>2419.6$ & $>2419.6$ & $>2419.6$ & $\mathrm{~N} / \mathrm{A}$ \\
\hline 0.75 & 15 & 4 & 14 & 0 & 16.1 & 1610 & 1610 & 2.16 \\
\hline 0.75 & 30 & 2 & 49 & 41 & 1203.3 & 1203.3 & 1203.3 & 2.29 \\
\hline 1.5 & 1 & 3 & 49 & 35 & 816.4 & 8164 & 8164 & 1.46 \\
\hline 1.5 & 2 & 3 & 48 & 22 & 298.7 & 2987 & 2987 & 1.89 \\
\hline 1.5 & 3 & 1 & 49 & 48 & $>2419.6$ & $>2419.6$ & $>2419.6$ & $\mathrm{~N} / \mathrm{A}$ \\
\hline 1.5 & 3 & 3 & 43 & 12 & 124.6 & 1246 & 1246 & 2.27 \\
\hline 1.5 & 5 & 2 & 49 & 33 & 727 & 727 & 727 & 2.51 \\
\hline 1.5 & 15 & 1 & 49 & 40 & 1119.9 & 111.99 & 111.99 & 3.32 \\
\hline 1.5 & 30 & 1 & 49 & 33 & 727 & 72.7 & 72.7 & 3.51 \\
\hline 3 & 1 & 2 & 49 & 44 & 1553.1 & 1553.1 & 1553.1 & 2.18 \\
\hline 3 & 2 & 1 & 49 & 46 & 1986.3 & 198.63 & 198.63 & 3.07 \\
\hline 3 & 3 & 1 & 49 & 38 & 980.4 & 98.04 & 98.04 & 3.38 \\
\hline 3 & 5 & 1 & 48 & 29 & 416 & 41.6 & 41.6 & 3.75 \\
\hline 3 & 15 & 1 & 39 & 11 & 95.9 & 9.59 & 9.59 & 4.39 \\
\hline 5 & 1 & 1 & 49 & 47 & 2419.6 & 241.96 & 241.96 & 2.98 \\
\hline 5 & 2 & 1 & 48 & 20 & 272.3 & 27.23 & 27.23 & 3.93 \\
\hline 5 & 3 & 1 & 29 & 4 & 48 & 4.8 & 4.8 & 4.69 \\
\hline 5 & 5 & 1 & 9 & 1 & 10.9 & 1.09 & 1.09 & 5.33 \\
\hline 5 & 3 & 1 & 45 & 9 & 131.4 & 13.14 & 13.14 & 6.38 \\
\hline 5 & 5 & 1 & 2 & 0 & 2 & 0.2 & 0.2 & 8.19 \\
\hline 5 & 15 & 1 & 0 & 0 & 0 & 0 & 0.1 & 8.50 \\
\hline
\end{tabular}




\begin{tabular}{|c|c|c|c|c|c|c|c|c|}
\hline $\begin{array}{l}\text { Date of } \\
\text { Expt: }\end{array}$ & \multicolumn{8}{|l|}{$8 / 4 / 2005$} \\
\hline Expt \#: & \multicolumn{8}{|l|}{75} \\
\hline Date read: & \multicolumn{8}{|l|}{$8 / 5 / 2005$} \\
\hline Purpose: & \multicolumn{8}{|c|}{ Dosage Response Curve for Enterococci } \\
\hline WS: & \multicolumn{8}{|c|}{$\begin{array}{l}\text { Enterococci grown in } 5: 1 \mathrm{IO}: \mathrm{NB} \text { for } 6 \text { days, spun, washed } \mathrm{X} 3 \text {, and resuspended in } \\
5: 1 \mathrm{IO} / \mathrm{diH} 2 \mathrm{O}\end{array}$} \\
\hline Conc.(mg/l) & $\begin{array}{l}\text { time } \\
(\min )\end{array}$ & dilution & $\begin{array}{l}\lg \text { wls } \\
\text { pos }\end{array}$ & $\begin{array}{l}\text { sm wls } \\
\text { pos }\end{array}$ & $\begin{array}{l}\text { MPN/ } \\
100 \mathrm{ml}\end{array}$ & $\mathrm{MPN} / \mathrm{ml}$ & $\begin{array}{l}\text { calc } \\
\mathrm{MPN} / \mathrm{ml}\end{array}$ & $\begin{array}{l}\log \\
\text { redctn. }\end{array}$ \\
\hline 0 & 0 & 3 & 49 & 48 & $>2419.6$ & $>2419.6$ & $>2419.6$ & $\mathrm{~N} / \mathrm{A}$ \\
\hline 0 & 0 & 5 & 46 & 24 & 233.3 & 233300 & 233300 & $\mathrm{~N} / \mathrm{A}$ \\
\hline 0 & 0 & 7 & 5 & 0 & 5 & 500000 & 500000 & $\mathrm{~N} / \mathrm{A}$ \\
\hline 0.25 & 1 & 2 & 49 & 48 & $>2419.6$ & $>2419.6$ & $>2419.6$ & $\mathrm{~N} / \mathrm{A}$ \\
\hline 0.25 & 1 & 4 & 49 & 35 & 816.4 & 81640 & 81640 & 0.46 \\
\hline 0.25 & 2 & 2 & 49 & 48 & $>2419.6$ & $>2419.6$ & $>2419.6$ & $\mathrm{~N} / \mathrm{A}$ \\
\hline 0.25 & 2 & 4 & 49 & 29 & 579.4 & 57940 & 57940 & 0.60 \\
\hline 0.25 & 3 & 2 & 49 & 48 & $>2419.6$ & $>2419.6$ & $>2419.6$ & $\mathrm{~N} / \mathrm{A}$ \\
\hline 0.25 & 3 & 4 & 48 & 28 & 396.8 & 39680 & 39680 & 0.77 \\
\hline 0.25 & 5 & 2 & 49 & 48 & $>2419.6$ & $>2419.6$ & $>2419.6$ & $\mathrm{~N} / \mathrm{A}$ \\
\hline 0.25 & 5 & 4 & 49 & 22 & 387.3 & 38730 & 38730 & 0.78 \\
\hline 0.25 & 15 & 2 & 49 & 48 & $>2419.6$ & $>2419.6$ & $>2419.6$ & $\mathrm{~N} / \mathrm{A}$ \\
\hline 0.25 & 15 & 4 & 48 & 21 & 285.1 & 28510 & 28510 & 0.91 \\
\hline 0.25 & 30 & 3 & 49 & 46 & 1986.3 & 19863 & 19863 & 1.07 \\
\hline 0.75 & 1 & 2 & 49 & 48 & $>2419.6$ & $>2419.6$ & $>2419.6$ & $\mathrm{~N} / \mathrm{A}$ \\
\hline 0.75 & 1 & 4 & 47 & 18 & 206.4 & 20640 & 20640 & 1.05 \\
\hline 0.75 & 2 & 2 & 49 & 48 & $>2419.6$ & $>2419.6$ & $>2419.6$ & $\mathrm{~N} / \mathrm{A}$ \\
\hline 0.75 & 2 & 4 & 45 & 15 & 157.6 & 15760 & 15760 & 1.17 \\
\hline 0.75 & 3 & 2 & 49 & 48 & $>2419.6$ & $>2419.6$ & $>2419.6$ & $\mathrm{~N} / \mathrm{A}$ \\
\hline 0.75 & 3 & 4 & 42 & 4 & 93.2 & 9320 & 9320 & 1.40 \\
\hline 0.75 & 5 & 2 & 49 & 48 & $>2419.6$ & $>2419.6$ & $>2419.6$ & $\mathrm{~N} / \mathrm{A}$ \\
\hline 0.75 & 5 & 4 & 36 & 3 & 65.7 & 6570 & 6570 & 1.55 \\
\hline 0.75 & 15 & 1 & 49 & 48 & $>2419.6$ & $>2419.6$ & $>2419.6$ & $\mathrm{~N} / \mathrm{A}$ \\
\hline 0.75 & 15 & 4 & 22 & 0 & 28.2 & 2820 & 2820 & 1.92 \\
\hline 0.75 & 30 & 2 & 49 & 44 & 1553.1 & 1553.1 & 1553.1 & 2.18 \\
\hline 1.5 & 1 & 3 & 49 & 34 & 770.1 & 7701 & 7701 & 1.48 \\
\hline 1.5 & 2 & 3 & 48 & 20 & 272.3 & 2723 & 2723 & 1.93 \\
\hline 1.5 & 3 & 1 & 49 & 48 & $>2419.6$ & $>2419.6$ & $>2419.6$ & $\mathrm{~N} / \mathrm{A}$ \\
\hline 1.5 & 3 & 3 & 40 & 12 & 106.7 & 1067 & 1067 & 2.34 \\
\hline 1.5 & 5 & 2 & 46 & 34 & 331.4 & 331.4 & 331.4 & 2.85 \\
\hline 1.5 & 15 & 1 & 49 & 40 & 1119.9 & 111.99 & 111.99 & 3.32 \\
\hline 1.5 & 30 & 1 & 49 & 27 & 517.2 & 51.72 & 51.72 & 3.65 \\
\hline 3 & 1 & 2 & 49 & 44 & 1553.1 & 1553.1 & 1553.1 & 2.18 \\
\hline 3 & 2 & 1 & 49 & 47 & 2419.6 & 241.96 & 241.96 & 2.98 \\
\hline 3 & 3 & 1 & 49 & 43 & 1413.1 & 141.31 & 141.31 & 3.22 \\
\hline 3 & 5 & 1 & 49 & 26 & 488.4 & 48.84 & 48.84 & 3.68 \\
\hline 3 & 15 & 1 & 49 & 15 & 261.3 & 26.13 & 26.13 & 3.95 \\
\hline 5 & 1 & 1 & 49 & 46 & 1986.3 & 198.63 & 198.63 & 3.07 \\
\hline 5 & 2 & 1 & 49 & 33 & 727 & 72.7 & 72.7 & 3.51 \\
\hline 5 & 3 & 1 & 38 & 10 & 88.6 & 8.86 & 8.86 & 4.42 \\
\hline 5 & 5 & 1 & 18 & 7 & 30.7 & 3.07 & 3.07 & 4.88 \\
\hline 5 & 3 & 1 & 45 & 9 & 131.4 & 13.14 & 13.14 & 6.38 \\
\hline 5 & 5 & 1 & 2 & 0 & 2 & 0.2 & 0.2 & 8.19 \\
\hline 5 & 15 & 1 & 0 & 0 & 0 & 0 & 0.1 & 8.50 \\
\hline
\end{tabular}




\begin{tabular}{|c|c|c|c|c|c|c|c|c|}
\hline $\begin{array}{l}\text { Date of } \\
\text { Expt: }\end{array}$ & \multicolumn{8}{|c|}{$8 / 23 / 2005$} \\
\hline Expt \#: & \multicolumn{8}{|c|}{81} \\
\hline Date read: & \multicolumn{8}{|c|}{$8 / 24 / 2005$} \\
\hline Purpose: & \multicolumn{8}{|c|}{ Dosage Response Curve for Enterococci } \\
\hline WS: & \multicolumn{8}{|c|}{$\begin{array}{l}\text { Enterococci grown in } 5: 1 \mathrm{IO}: \mathrm{NB} \text { for } 6 \text { days, spun, washed } \mathrm{X} 3 \text {, and resuspended in } \\
5: 1 \mathrm{IO} / \mathrm{diH} 2 \mathrm{O}\end{array}$} \\
\hline Conc.(mg/l) & $\begin{array}{l}\text { time } \\
(\min )\end{array}$ & dilution & $\begin{array}{l}\lg \text { wls } \\
\text { pos }\end{array}$ & $\begin{array}{l}\text { sm wls } \\
\text { pos }\end{array}$ & $\begin{array}{l}\text { MPN/ } \\
100 \mathrm{ml}\end{array}$ & $\mathrm{MPN} / \mathrm{ml}$ & $\begin{array}{l}\text { calc } \\
\mathrm{MPN} / \mathrm{ml}\end{array}$ & $\begin{array}{l}\log \\
\text { redctn. }\end{array}$ \\
\hline 0 & 0 & 3 & 49 & 47 & 2419.6 & 24196 & 24196 & $\mathrm{~N} / \mathrm{A}$ \\
\hline 0 & 0 & 5 & 40 & 5 & 85.7 & 85700 & 85700 & $\mathrm{~N} / \mathrm{A}$ \\
\hline 0 & 0 & 7 & 1 & 0 & 1 & 100000 & 100000 & $\mathrm{~N} / \mathrm{A}$ \\
\hline 0.25 & 1 & 2 & 49 & 48 & $>2419.6$ & $>2419.6$ & $>2419.6$ & $\mathrm{~N} / \mathrm{A}$ \\
\hline 0.25 & 1 & 5 & 28 & 0 & 39.5 & 39500 & 39500 & 0.34 \\
\hline 0.25 & 2 & 2 & 49 & 46 & 1986.3 & 1986.3 & 1986.3 & 1.63 \\
\hline 0.25 & 2 & 5 & 17 & 0 & 20.3 & 20300 & 20300 & 0.63 \\
\hline 0.25 & 3 & 2 & 49 & 47 & 2419.6 & 2419.6 & 2419.6 & 1.55 \\
\hline 0.25 & 3 & 5 & 12 & 0 & 13.5 & 13500 & 13500 & 0.80 \\
\hline 0.25 & 5 & 2 & 49 & 48 & $>2419.6$ & $>2419.6$ & $>2419.6$ & $\mathrm{~N} / \mathrm{A}$ \\
\hline 0.25 & 5 & 5 & 8 & 0 & 8.6 & 8600 & 8600 & 1.00 \\
\hline 0.25 & 15 & 2 & 47 & 34 & 403.4 & 403.4 & 403.4 & 2.33 \\
\hline 0.25 & 15 & 5 & 7 & 0 & 7.5 & 7500 & 7500 & 1.06 \\
\hline 0.25 & 30 & 2 & 49 & 43 & 1413.6 & 1413.6 & 1413.6 & 1.78 \\
\hline 0.25 & 30 & 5 & 5 & 0 & 5.2 & 5200 & 5200 & 1.22 \\
\hline 0.75 & 1 & 2 & 49 & 46 & 1986.3 & 1986.3 & 1986.3 & 1.63 \\
\hline 0.75 & 1 & 5 & 5 & 0 & 5.2 & 5200 & 5200 & 1.22 \\
\hline 0.75 & 2 & 2 & 49 & 44 & 1553.1 & 1553.1 & 1553.1 & 1.74 \\
\hline 0.75 & 2 & 5 & 3 & 0 & 3.1 & 3100 & 3100 & 1.44 \\
\hline 0.75 & 3 & 2 & 49 & 32 & 686.7 & 686.7 & 686.7 & 2.10 \\
\hline 0.75 & 3 & 5 & 0 & 0 & 0 & 0 & 1000 & 1.93 \\
\hline 0.75 & 5 & 2 & 48 & 15 & 218.7 & 218.7 & 218.7 & 2.59 \\
\hline 0.75 & 5 & 5 & 0 & 1 & 1 & 1000 & 1000 & 1.93 \\
\hline 0.75 & 15 & 2 & 30 & 6 & 53.7 & 53.7 & 53.7 & 3.20 \\
\hline 0.75 & 15 & 4 & 0 & 0 & 0 & 0 & 100 & 2.93 \\
\hline 0.75 & 30 & 2 & 26 & 3 & 39.9 & 39.9 & 39.9 & 3.33 \\
\hline 0.75 & 30 & 4 & 0 & 0 & 0 & 0 & 100 & 2.93 \\
\hline 1.5 & 1 & 2 & 43 & 4 & 99 & 99 & 99 & 2.94 \\
\hline 1.5 & 2 & 2 & 25 & 0 & 33.6 & 33.6 & 33.6 & 3.41 \\
\hline 1.5 & 2 & 4 & 0 & 0 & 0 & 0 & 100 & 2.93 \\
\hline 1.5 & 3 & 2 & 14 & 1 & 17.3 & 17.3 & 17.3 & 3.69 \\
\hline 1.5 & 5 & 1 & 45 & 9 & 131.4 & 13.14 & 13.14 & 3.81 \\
\hline 1.5 & 15 & 1 & 42 & 6 & 98.8 & 9.88 & 9.88 & 3.94 \\
\hline 1.5 & 30 & 1 & 22 & 3 & 32.3 & 3.23 & 3.23 & 4.42 \\
\hline 3 & 1 & 1 & 48 & 17 & 238.2 & 23.82 & 23.82 & 3.56 \\
\hline 3 & 2 & 1 & 21 & 8 & 37.3 & 3.73 & 3.73 & 4.36 \\
\hline 3 & 3 & 1 & 17 & 1 & 21.6 & 2.16 & 2.16 & 4.60 \\
\hline 3 & 5 & 1 & 14 & 2 & 18.5 & 1.85 & 1.85 & 4.67 \\
\hline 3 & 15 & 1 & 5 & 1 & 6.3 & 0.63 & 0.63 & 5.13 \\
\hline 5 & 1 & 1 & 17 & 5 & 26.6 & 2.66 & 2.66 & 4.51 \\
\hline 5 & 2 & 1 & 4 & 2 & 6.2 & 0.62 & 0.62 & 5.14 \\
\hline 5 & 3 & 1 & 2 & 0 & 2 & 0.2 & 0.2 & 5.63 \\
\hline 5 & 5 & 1 & 1 & 0 & 1 & 0.1 & 0.1 & 5.93 \\
\hline 5 & 15 & 1 & 0 & 0 & 0 & 0 & 0.1 & 8.50 \\
\hline
\end{tabular}




\begin{tabular}{|c|c|c|c|c|c|c|c|c|}
\hline $\begin{array}{l}\text { Date of } \\
\text { Expt: }\end{array}$ & \multicolumn{8}{|c|}{$8 / 23 / 2005$} \\
\hline Expt \#: & \multicolumn{8}{|c|}{82} \\
\hline Date read: & \multicolumn{8}{|c|}{$8 / 24 / 2005$} \\
\hline Purpose: & \multicolumn{8}{|c|}{ Dosage Response Curve for Enterococci } \\
\hline WS: & \multicolumn{8}{|c|}{$\begin{array}{l}\text { Enterococci grown in } 5: 1 \mathrm{IO} \text { :NB for } 6 \text { days, spun, washed } \mathrm{X} 3 \text {, and resuspended in } \\
5: 1 \mathrm{IO} / \mathrm{diH} 2 \mathrm{O}\end{array}$} \\
\hline Conc.(mg/l) & $\begin{array}{l}\text { time } \\
(\min )\end{array}$ & dilution & $\begin{array}{l}\lg \text { wls } \\
\text { pos }\end{array}$ & $\begin{array}{l}\text { sm wls } \\
\text { pos }\end{array}$ & $\begin{array}{l}\text { MPN/ } \\
100 \mathrm{ml}\end{array}$ & $\mathrm{MPN} / \mathrm{ml}$ & $\begin{array}{l}\text { calc } \\
\mathrm{MPN} / \mathrm{ml}\end{array}$ & $\begin{array}{l}\text { log } \\
\text { redctn. }\end{array}$ \\
\hline 0 & 0 & 3 & 49 & 47 & 2419.6 & 24196 & 24196 & $\mathrm{~N} / \mathrm{A}$ \\
\hline 0 & 0 & 5 & 40 & 5 & 85.7 & 85700 & 85700 & $\mathrm{~N} / \mathrm{A}$ \\
\hline 0 & 0 & 7 & 1 & 0 & 1 & 100000 & 100000 & $\mathrm{~N} / \mathrm{A}$ \\
\hline 0.25 & 1 & 2 & 49 & 48 & $>2419.6$ & $>2419.6$ & $>2419.6$ & $\mathrm{~N} / \mathrm{A}$ \\
\hline 0.25 & 1 & 5 & 31 & 6 & 56.3 & 56300 & 56300 & 0.18 \\
\hline 0.25 & 2 & 2 & 49 & 46 & 1986.3 & 1986.3 & 1986.3 & 1.63 \\
\hline 0.25 & 2 & 5 & 22 & 0 & 28.2 & 28200 & 28200 & 0.48 \\
\hline 0.25 & 3 & 2 & 48 & 47 & 960.6 & 960.6 & 960.6 & 1.95 \\
\hline 0.25 & 3 & 5 & 16 & 1 & 20.1 & 20100 & 20100 & 0.63 \\
\hline 0.25 & 5 & 2 & 48 & 40 & 689.3 & 689.3 & 689.3 & 2.09 \\
\hline 0.25 & 5 & 5 & 7 & 1 & 8.5 & 8500 & 8500 & 1.00 \\
\hline 0.25 & 15 & 2 & 49 & 44 & 1553.1 & 1553.1 & 1553.1 & 1.74 \\
\hline 0.25 & 15 & 5 & 5 & 1 & 6.3 & 6300 & 6300 & 1.13 \\
\hline 0.25 & 30 & 2 & 49 & 43 & 1413.6 & 1413.6 & 1413.6 & 1.78 \\
\hline 0.25 & 30 & 5 & 6 & 0 & 6.3 & 6300 & 6300 & 1.13 \\
\hline 0.75 & 1 & 2 & 49 & 47 & 2419.6 & 2419.6 & 2419.6 & 1.55 \\
\hline 0.75 & 1 & 5 & 6 & 1 & 7.4 & 7400 & 7400 & 1.06 \\
\hline 0.75 & 2 & 2 & 47 & 38 & 472.1 & 472.1 & 472.1 & 2.26 \\
\hline 0.75 & 2 & 5 & 6 & 0 & 6.3 & 6300 & 6300 & 1.13 \\
\hline 0.75 & 3 & 2 & 45 & 30 & 250.4 & 250.4 & 250.4 & 2.53 \\
\hline 0.75 & 3 & 5 & 3 & 0 & 3.1 & 3100 & 3100 & 1.44 \\
\hline 0.75 & 5 & 2 & 43 & 26 & 182.3 & 182.3 & 182.3 & 2.67 \\
\hline 0.75 & 5 & 5 & 0 & 0 & 0 & 0 & 1 & 4.93 \\
\hline 0.75 & 15 & 2 & 32 & 3 & 53.8 & 53.8 & 53.8 & 3.20 \\
\hline 0.75 & 15 & 4 & 0 & 0 & 0 & 0 & 1 & 4.93 \\
\hline 0.75 & 30 & 2 & 18 & 5 & 28.1 & 28.1 & 28.1 & 3.48 \\
\hline 0.75 & 30 & 4 & 0 & 0 & 0 & 0 & 1 & 4.93 \\
\hline 1.5 & 1 & 2 & 24 & 0 & 31.7 & 31.7 & 31.7 & 3.43 \\
\hline 1.5 & 2 & 2 & 10 & 2 & 13.2 & 13.2 & 13.2 & 3.81 \\
\hline 1.5 & 2 & 4 & 0 & 0 & 0 & 0 & 1 & 4.93 \\
\hline 1.5 & 3 & 2 & 9 & 0 & 9.8 & 9.8 & 9.8 & 3.94 \\
\hline 1.5 & 5 & 1 & 40 & 7 & 90.8 & 9.08 & 9.08 & 3.97 \\
\hline 1.5 & 15 & 1 & 39 & 6 & 83.6 & 8.36 & 8.36 & 4.01 \\
\hline 1.5 & 30 & 1 & 25 & 1 & 35 & 3.5 & 3.5 & 4.39 \\
\hline 3 & 1 & 1 & 18 & 7 & 30.7 & 3.07 & 3.07 & 4.45 \\
\hline 3 & 2 & 1 & 18 & 2 & 24.3 & 2.43 & 2.43 & 4.55 \\
\hline 3 & 3 & 1 & 15 & 4 & 22.3 & 2.23 & 2.23 & 4.58 \\
\hline 3 & 5 & 1 & 12 & 1 & 14.6 & 1.46 & 1.46 & 4.77 \\
\hline 3 & 15 & 1 & 4 & 1 & 5.2 & 0.52 & 0.52 & 5.22 \\
\hline 5 & 1 & 1 & 15 & 3 & 21.1 & 2.11 & 2.11 & 4.61 \\
\hline 5 & 2 & 1 & 9 & 2 & 12 & 1.2 & 1.2 & 4.85 \\
\hline 5 & 3 & 1 & 3 & 0 & 3.1 & 0.31 & 0.31 & 5.44 \\
\hline 5 & 5 & 1 & 0 & 1 & 1 & 0.1 & 0.1 & 5.93 \\
\hline
\end{tabular}




\section{E.4 Dosage Response Experiments for Vibrio cholerae}

\begin{tabular}{|c|c|c|c|c|c|c|c|}
\hline \multirow{2}{*}{\begin{tabular}{|l|} 
Date of Expt: \\
Expt \#:
\end{tabular}} & \multicolumn{7}{|l|}{$12 / 6 / 05$} \\
\hline & \multicolumn{7}{|l|}{94} \\
\hline Date read: & \multicolumn{7}{|l|}{$12 / 13 / 05$} \\
\hline WS: & \multicolumn{7}{|c|}{$\begin{array}{l}\text { Vibrio grown in 5:1 IO:NB for } 5 \text { days, then washed } X 3 \mathrm{w} / \mathrm{IO} \text {, then } 1 \times \text { low speed } \\
\text { centrifugation, and resuspended in 5:1 IO:NB }\end{array}$} \\
\hline & & \multicolumn{2}{|c|}{ Number of Colonies } & & \multicolumn{2}{|c|}{ Colony Count } & \\
\hline Specimen/QC & Dilution & Plate 1 & Plate 2 & ave count & & & \\
\hline QC open, hood & & 0 & & & 0 & & \\
\hline QC closed, hood & & 0 & & & 0 & & \\
\hline QC open, counter & & nd & & & nd & & \\
\hline dilution buffer & & 0 & & & 0 & & \\
\hline Instant Ocean & & nd & & & nd & & \\
\hline \multicolumn{8}{|c|}{ all specs. w/ferrate stopped w/TS } \\
\hline & & & \multicolumn{2}{|c|}{ Number of Colonies } & & & \\
\hline Conc (mg/l) & $\begin{array}{l}\text { Time } \\
\text { (min) }\end{array}$ & Dilution & Plate 1 & Plate 2 & $\begin{array}{l}\text { Ave. } \\
\text { Count }\end{array}$ & Calc. Count & Log redctn. \\
\hline 0 & 0 & 6 & 0 & 0 & 0 & 100000 & $\mathrm{~N} / \mathrm{A}$ \\
\hline 0 & 0 & 4 & 0 & 1 & 0.5 & 5000 & $\mathrm{~N} / \mathrm{A}$ \\
\hline 0 & 0 & 3 & 23 & 19 & 21 & 21000 & $\mathrm{~N} / \mathrm{A}$ \\
\hline 0.5 & 1 & 3 & 4 & 5 & 4.5 & 4500 & 0.67 \\
\hline 0.5 & 1 & 1 & 141 & awcg & 141 & 1410 & 1.17 \\
\hline 0.5 & 2 & 3 & 0 & 0 & 0 & 1000 & 1.32 \\
\hline 0.5 & 2 & 1 & 84 & 88 & 86 & 860 & 1.39 \\
\hline 0.5 & 3 & 3 & 0 & 4 & 2 & 2000 & 1.02 \\
\hline 0.5 & 3 & 1 & 49 & cont & 49 & 490 & 1.63 \\
\hline 0.5 & 5 & 3 & 0 & 0 & 0 & 1000 & 1.32 \\
\hline 0.5 & 5 & 1 & 28 & 22 & 25 & 250 & 1.92 \\
\hline 0.5 & 15 & 3 & 0 & 0 & 0 & 1000 & 1.32 \\
\hline 0.5 & 15 & 1 & 23 & 21 & 22 & 220 & 1.98 \\
\hline 0.5 & 30 & 2 & 1 & 4 & 2.5 & 250 & 1.92 \\
\hline 0.5 & 30 & 0 & 87 & $\mathrm{nd}$ & 87 & 87 & 2.38 \\
\hline 1 & 1 & 3 & 0 & 0 & 0 & 1000 & 1.32 \\
\hline 1 & 1 & 1 & 8 & 12 & 10 & 100 & 2.32 \\
\hline 1 & 2 & 3 & 0 & 0 & 0 & 1000 & 1.32 \\
\hline 1 & 2 & 1 & 2 & 7 & 4.5 & 45 & 2.67 \\
\hline 1 & 3 & 3 & 0 & 0 & 0 & 1000 & 1.32 \\
\hline 1 & 3 & 1 & 0 & 9 & 4.5 & 45 & 2.67 \\
\hline 1 & 5 & 3 & 0 & 0 & 0 & 1000 & 1.32 \\
\hline 1 & 5 & 1 & 2 & 6 & 4 & 40 & 2.72 \\
\hline 1 & 15 & 3 & 0 & 0 & 0 & 1000 & 1.32 \\
\hline 1 & 15 & 1 & 1 & 0 & 0.5 & 5 & 3.62 \\
\hline 1 & 30 & 2 & 0 & 0 & 0 & 100 & 2.32 \\
\hline 1 & 30 & 0 & 2 & 7 & 4.5 & 4.5 & 3.67 \\
\hline
\end{tabular}




\begin{tabular}{|c|c|c|c|c|c|c|c|}
\hline & & & Number of & Colonies & & & \\
\hline Conc (mg/l) & $\begin{array}{l}\text { Time } \\
(\min )\end{array}$ & Dilution & Plate 1 & Plate 2 & $\begin{array}{l}\text { Ave. } \\
\text { Count }\end{array}$ & $\begin{array}{l}\text { Calc. } \\
\text { Count }\end{array}$ & $\begin{array}{l}\text { Log } \\
\text { redctn. }\end{array}$ \\
\hline 2.5 & 1 & 3 & 0 & 0 & 0 & 1000 & 1.32 \\
\hline 2.5 & 1 & 1 & 3 & 2 & 2.5 & 25 & 2.92 \\
\hline 2.5 & 2 & 3 & 0 & 0 & 0 & 1000 & 1.32 \\
\hline 2.5 & 2 & 1 & 3 & 0 & 1.5 & 15 & 3.15 \\
\hline 2.5 & 3 & 2 & 0 & 0 & 0 & 100 & 2.32 \\
\hline 2.5 & 3 & 0 & 2 & 5 & 3.5 & 3.5 & 3.78 \\
\hline 2.5 & 5 & 2 & 0 & 0 & 0 & 100 & 2.32 \\
\hline 2.5 & 5 & 0 & 6 & awcg & 6 & 6 & 3.54 \\
\hline 2.5 & 15 & 2 & 0 & 0 & 0 & 100 & 2.32 \\
\hline 2.5 & 15 & 0 & 2 & 3 & 2.5 & 2.5 & 3.92 \\
\hline 2.5 & 30 & 1 & 0 & 0 & 0 & 10 & 3.32 \\
\hline 2.5 & 30 & 0 & 2 & nd & 2 & 2 & 4.02 \\
\hline 4 & 1 & 2 & 0 & 0 & 0 & 100 & 2.32 \\
\hline 4 & 1 & 0 & 9 & 11 & 10 & 10 & 3.32 \\
\hline 4 & 2 & 2 & 0 & 0 & 0 & 100 & 2.32 \\
\hline 4 & 2 & 0 & 0 & 7 & 3.5 & 3.5 & 3.78 \\
\hline 4 & 3 & 1 & 0 & 0 & 0 & 10 & 3.32 \\
\hline 4 & 3 & 0 & 4 & awcg & 4 & 4 & 3.72 \\
\hline 4 & 5 & 0 & 0 & 0 & 0 & 1 & 4.32 \\
\hline 4 & 15 & 0 & 0 & 0 & 0 & 1 & 4.32 \\
\hline 5 & 1 & 2 & 0 & 0 & 0 & 100 & 2.32 \\
\hline 5 & 1 & 0 & 5 & 6 & 5.5 & 5.5 & 3.58 \\
\hline 5 & 2 & 2 & 0 & 0 & 0 & 100 & 2.32 \\
\hline 5 & 2 & 0 & 2 & 8 & 5 & 5 & 3.62 \\
\hline 5 & 3 & 0 & 2 & 0 & 1 & 1 & 4.32 \\
\hline 5 & 5 & 0 & 0 & 0 & 0 & 1 & 4.32 \\
\hline
\end{tabular}




\begin{tabular}{|c|c|c|c|c|c|c|c|}
\hline Date of Expt: & \multicolumn{7}{|l|}{$12 / 6 / 05$} \\
\hline Expt \#: & \multicolumn{7}{|l|}{95} \\
\hline Date read: & \multicolumn{7}{|l|}{$12 / 13 / 05$} \\
\hline WS: & \multicolumn{7}{|c|}{$\begin{array}{l}\text { V. cholerae grown in } 5: 1 \mathrm{IO}: \mathrm{NB} \text { for } 5 \text { days, then washed } \mathrm{X} 3 \mathrm{w} / \mathrm{IO} \text {, then } 1 \mathrm{x} \text { low } \\
\text { speed centrifugation, and resuspended in } 5: 1 \mathrm{IO}: \mathrm{NB}\end{array}$} \\
\hline & & $\begin{array}{l}\text { Number of } \\
\text { Colonies }\end{array}$ & & & \multirow[b]{2}{*}{$\begin{array}{l}\text { Colony } \\
\text { Count }\end{array}$} & & \\
\hline Specimen/QC & Dilution & Plate 1 & $\begin{array}{l}\text { Plate } \\
2\end{array}$ & $\begin{array}{l}\text { ave } \\
\text { count }\end{array}$ & & & \\
\hline QC open, hood & & 0 & & & 0 & & \\
\hline $\begin{array}{l}\text { QC closed, } \\
\text { hood }\end{array}$ & & 0 & & & 0 & & \\
\hline $\begin{array}{l}\text { QC open, } \\
\text { counter }\end{array}$ & & nd & & & nd & & \\
\hline dilution buffer & & 0 & & & 0 & & \\
\hline Instant Ocean & & nd & & & nd & & \\
\hline \multicolumn{8}{|c|}{ all specs. w/ferrate stopped w/TS } \\
\hline & & & \multicolumn{2}{|c|}{$\begin{array}{l}\text { Number of } \\
\text { Colonies }\end{array}$} & & & \\
\hline Conc $(\mathrm{mg} / \mathrm{l})$ & $\begin{array}{l}\text { Time } \\
(\min )\end{array}$ & Dilution & $\begin{array}{l}\text { Plate } \\
1\end{array}$ & Plate 2 & $\begin{array}{l}\text { Ave. } \\
\text { Count }\end{array}$ & $\begin{array}{l}\text { Calc. } \\
\text { Count }\end{array}$ & $\begin{array}{l}\text { Log } \\
\text { redctn. }\end{array}$ \\
\hline 0 & 0 & 6 & 0 & 0 & 0 & 100000 & $\mathrm{~N} / \mathrm{A}$ \\
\hline 0 & 0 & 4 & 0 & 1 & 0.5 & 5000 & $\mathrm{~N} / \mathrm{A}$ \\
\hline 0 & 0 & 3 & 23 & 19 & 21 & 21000 & $\mathrm{~N} / \mathrm{A}$ \\
\hline 0.5 & 1 & 3 & 4 & 5 & 4.5 & 4500 & 0.92 \\
\hline 0.5 & 1 & 1 & 141 & awcg & 141 & 1410 & 1.32 \\
\hline 0.5 & 2 & 3 & 0 & 0 & 0 & 1000 & 1.15 \\
\hline 0.5 & 2 & 1 & 84 & 88 & 86 & 860 & 1.35 \\
\hline 0.5 & 3 & 3 & 0 & 4 & 2 & 2000 & 1.15 \\
\hline 0.5 & 3 & 1 & 49 & cont & 49 & 490 & 1.38 \\
\hline 0.5 & 5 & 3 & 0 & 0 & 0 & 1000 & 1.32 \\
\hline 0.5 & 5 & 1 & 28 & 22 & 25 & 250 & 1.48 \\
\hline 0.5 & 15 & 3 & 0 & 0 & 0 & 1000 & 1.32 \\
\hline 0.5 & 15 & 1 & 23 & 21 & 22 & 220 & 1.66 \\
\hline 0.5 & 30 & 2 & 1 & 4 & 2.5 & 250 & 2.32 \\
\hline 0.5 & 30 & 0 & 87 & nd & 87 & 87 & 2.44 \\
\hline 1 & 1 & 3 & 0 & 0 & 0 & 1000 & 1.32 \\
\hline 1 & 1 & 1 & 8 & 12 & 10 & 100 & 2.19 \\
\hline 1 & 2 & 3 & 0 & 0 & 0 & 1000 & 1.32 \\
\hline 1 & 2 & 1 & 2 & 7 & 4.5 & 45 & 2.18 \\
\hline 1 & 3 & 3 & 0 & 0 & 0 & 1000 & 1.32 \\
\hline 1 & 3 & 1 & 0 & 9 & 4.5 & 45 & 2.42 \\
\hline 1 & 5 & 3 & 0 & 0 & 0 & 1000 & 1.32 \\
\hline 1 & 5 & 1 & 2 & 6 & 4 & 40 & 2.72 \\
\hline 1 & 15 & 3 & 0 & 0 & 0 & 1000 & 1.32 \\
\hline 1 & 15 & 1 & 1 & 0 & 0.5 & 5 & 2.92 \\
\hline 1 & 30 & 2 & 0 & 0 & 0 & 100 & 2.32 \\
\hline 1 & 30 & 0 & 2 & 7 & 4.5 & 4.5 & 2.83 \\
\hline
\end{tabular}




\begin{tabular}{|c|c|c|c|c|c|c|c|}
\hline & & & Number of & Colonies & & & \\
\hline Conc (mg/l) & $\begin{array}{l}\text { Time } \\
(\min )\end{array}$ & Dilution & Plate 1 & Plate 2 & $\begin{array}{l}\text { Ave. } \\
\text { Count }\end{array}$ & $\begin{array}{l}\text { Calc. } \\
\text { Count }\end{array}$ & $\begin{array}{l}\text { Log } \\
\text { redctn. }\end{array}$ \\
\hline 2.5 & 1 & 3 & 0 & 0 & 0 & 1000 & 1.32 \\
\hline 2.5 & 1 & 1 & 3 & 2 & 2.5 & 25 & 2.67 \\
\hline 2.5 & 2 & 3 & 0 & 0 & 0 & 1000 & 1.32 \\
\hline 2.5 & 2 & 1 & 3 & 0 & 1.5 & 15 & 2.78 \\
\hline 2.5 & 3 & 2 & 0 & 0 & 0 & 100 & 2.32 \\
\hline 2.5 & 3 & 0 & 2 & 5 & 3.5 & 3.5 & 3.48 \\
\hline 2.5 & 5 & 2 & 0 & 0 & 0 & 100 & 2.32 \\
\hline 2.5 & 5 & 0 & 6 & awcg & 6 & 6 & 3.54 \\
\hline 2.5 & 15 & 2 & 0 & 0 & 0 & 100 & 2.32 \\
\hline 2.5 & 15 & 0 & 2 & 3 & 2.5 & 2.5 & 3.62 \\
\hline 2.5 & 30 & 1 & 0 & 0 & 0 & 10 & 3.32 \\
\hline 2.5 & 30 & 0 & 2 & nd & 2 & 2 & 3.85 \\
\hline 4 & 1 & 2 & 0 & 0 & 0 & 100 & 2.32 \\
\hline 4 & 1 & 0 & 9 & 11 & 10 & 10 & 3.19 \\
\hline 4 & 2 & 2 & 0 & 0 & 0 & 100 & 2.32 \\
\hline 4 & 2 & 0 & 0 & 7 & 3.5 & 3.5 & 3.48 \\
\hline 4 & 3 & 1 & 0 & 0 & 0 & 10 & 3.32 \\
\hline 4 & 3 & 0 & 4 & awcg & 4 & 4 & 3.42 \\
\hline 4 & 5 & 0 & 0 & 0 & 0 & 1 & 4.32 \\
\hline 4 & 15 & 0 & 0 & 0 & 0 & 1 & 4.32 \\
\hline 5 & 1 & 2 & 0 & 0 & 0 & 100 & 3.32 \\
\hline 5 & 1 & 0 & 5 & 6 & 5.5 & 5.5 & 3.28 \\
\hline 5 & 2 & 2 & 0 & 0 & 0 & 100 & 2.32 \\
\hline 5 & 2 & 0 & 2 & 8 & 5 & 5 & 3.72 \\
\hline 5 & 3 & 0 & 2 & 0 & 1 & 1 & 3.85 \\
\hline 5 & 5 & 0 & 0 & 0 & 0 & 1 & 4.62 \\
\hline
\end{tabular}




\begin{tabular}{|c|c|c|c|c|c|c|c|}
\hline Date of Expt: & \multicolumn{7}{|l|}{$12 / 8 / 05$} \\
\hline Expt \#: & \multicolumn{7}{|l|}{96} \\
\hline Date read: & \multicolumn{7}{|l|}{$12 / 15 / 05$} \\
\hline WS: & \multicolumn{7}{|c|}{$\begin{array}{l}\text { V. cholerae grown in } 5: 1 \mathrm{IO}: \mathrm{NB} \text { for } 7 \text { days, then washed } \mathrm{X} 3 \mathrm{w} / \mathrm{IO} \text {, then } 1 \mathrm{x} \text { low } \\
\text { speed centrifugation, and resuspended in 5:1 IO:NB }\end{array}$} \\
\hline & & $\begin{array}{l}\text { Number of } \\
\text { Colonies }\end{array}$ & & & \multirow[b]{2}{*}{$\begin{array}{l}\text { Colony } \\
\text { Count }\end{array}$} & & \\
\hline Specimen/QC & Dilution & Plate 1 & $\begin{array}{l}\text { Plate } \\
2\end{array}$ & $\begin{array}{l}\text { ave } \\
\text { count }\end{array}$ & & & \\
\hline QC open, hood & & 0 & & & 0 & & \\
\hline $\begin{array}{l}\text { QC closed, } \\
\text { hood }\end{array}$ & & 0 & & & 0 & & \\
\hline $\begin{array}{l}\text { QC open, } \\
\text { counter }\end{array}$ & & nd & & & nd & & \\
\hline dilution buffer & & 0 & & & 0 & & \\
\hline Instant Ocean & & 0 & & & 0 & & \\
\hline \multicolumn{8}{|c|}{ all specs. w/ferrate stopped w/TS } \\
\hline & & & \multicolumn{2}{|c|}{$\begin{array}{l}\text { Number of } \\
\text { Colonies }\end{array}$} & & & \\
\hline Conc (mg/l) & $\begin{array}{l}\text { Time } \\
(\min )\end{array}$ & Dilution & $\begin{array}{l}\text { Plate } \\
1\end{array}$ & Plate 2 & $\begin{array}{l}\text { Ave. } \\
\text { Count }\end{array}$ & $\begin{array}{l}\text { Calc. } \\
\text { Count }\end{array}$ & $\begin{array}{l}\text { Log } \\
\text { redctn. }\end{array}$ \\
\hline 0 & 0 & 6 & 0 & 0 & 0 & 100000 & $\mathrm{~N} / \mathrm{A}$ \\
\hline 0 & 0 & 4 & 1 & 3 & 2 & 20000 & $\mathrm{~N} / \mathrm{A}$ \\
\hline 0 & 0 & 3 & 16 & 13 & 14.5 & 14500 & $\mathrm{~N} / \mathrm{A}$ \\
\hline 0.5 & 1 & 3 & 2 & 3 & 2.5 & 2500 & 0.76 \\
\hline 0.5 & 1 & 1 & 139 & 144 & 141.5 & 1415 & 1.01 \\
\hline 0.5 & 2 & 3 & 0 & 0 & 0 & 1000 & 1.16 \\
\hline 0.5 & 2 & 1 & 76 & 62 & 69 & 690 & 1.32 \\
\hline 0.5 & 3 & 3 & 1 & 2 & 1.5 & 1500 & 0.99 \\
\hline 0.5 & 3 & 1 & 55 & 61 & 58 & 580 & 1.40 \\
\hline 0.5 & 5 & 3 & 0 & 0 & 0 & 1000 & 1.16 \\
\hline 0.5 & 5 & 1 & 28 & 30 & 29 & 290 & 1.70 \\
\hline 0.5 & 15 & 3 & 0 & 0 & 0 & 1000 & 1.16 \\
\hline 0.5 & 15 & 1 & 29 & 28 & 28.5 & 285 & 1.71 \\
\hline 0.5 & 30 & 2 & 5 & 1 & 3 & 300 & 1.68 \\
\hline 0.5 & 30 & 0 & awcg & 52 & 52 & 52 & 2.45 \\
\hline 1 & 1 & 3 & 2 & 0 & 1 & 1000 & 1.16 \\
\hline 1 & 1 & 1 & 13 & 19 & 16 & 160 & 1.96 \\
\hline 1 & 2 & 3 & 0 & 0 & 0 & 1000 & 1.16 \\
\hline 1 & 2 & 1 & 16 & 12 & 14 & 140 & 2.02 \\
\hline 1 & 3 & 3 & 0 & 0 & 0 & 1000 & 1.16 \\
\hline 1 & 3 & 1 & 5 & 11 & 8 & 80 & 2.26 \\
\hline 1 & 5 & 3 & 0 & 0 & 0 & 1000 & 1.16 \\
\hline 1 & 5 & 1 & 5 & 4 & 4.5 & 45 & 2.51 \\
\hline 1 & 15 & 3 & 0 & 0 & 0 & 1000 & 1.16 \\
\hline 1 & 15 & 1 & 0 & 4 & 2 & 20 & 2.86 \\
\hline 1 & 30 & 2 & 0 & 2 & 1 & 100 & 2.16 \\
\hline 1 & 30 & 0 & 9 & nd & 9 & 9 & 3.21 \\
\hline
\end{tabular}




\begin{tabular}{|c|c|c|c|c|c|c|c|}
\hline & & & Number of & Colonies & & & \\
\hline Conc (mg/l) & $\begin{array}{l}\text { Time } \\
(\min )\end{array}$ & Dilution & Plate 1 & Plate 2 & $\begin{array}{l}\text { Ave. } \\
\text { Count }\end{array}$ & $\begin{array}{l}\text { Calc. } \\
\text { Count }\end{array}$ & $\begin{array}{l}\text { Log } \\
\text { redctn. }\end{array}$ \\
\hline 2.5 & 1 & 3 & 1 & 0 & 0.5 & 500 & 1.46 \\
\hline 2.5 & 1 & 1 & 12 & 10 & 11 & 110 & 2.12 \\
\hline 2.5 & 2 & 3 & 0 & 0 & 0 & 1000 & 1.16 \\
\hline 2.5 & 2 & 1 & 7 & 8 & 7.5 & 75 & 2.29 \\
\hline 2.5 & 3 & 2 & 0 & 0 & 0 & 100 & 2.16 \\
\hline 2.5 & 3 & 0 & 7 & 5 & 6 & 6 & 3.38 \\
\hline 2.5 & 5 & 2 & 0 & 0 & 0 & 100 & 2.16 \\
\hline 2.5 & 5 & 0 & 5 & awcg & 5 & 5 & 3.46 \\
\hline 2.5 & 15 & 2 & 0 & 0 & 0 & 100 & 2.16 \\
\hline 2.5 & 15 & 0 & 8 & 2 & 5 & 5 & 3.46 \\
\hline 2.5 & 30 & 1 & 0 & 0 & 0 & 10 & 3.16 \\
\hline 2.5 & 30 & 0 & 4 & nd & 4 & 4 & 3.56 \\
\hline 4 & 1 & 2 & 0 & 0 & 0 & 100 & 2.16 \\
\hline 4 & 1 & 0 & 20 & 16 & 18 & 18 & 2.91 \\
\hline 4 & 2 & 2 & 1 & 0 & 0.5 & 50 & 2.46 \\
\hline 4 & 2 & 0 & awcg & 7 & 7 & 7 & 3.32 \\
\hline 4 & 3 & 1 & 0 & 0 & 0 & 10 & 3.16 \\
\hline 4 & 3 & 0 & 13 & 14 & 13.5 & 13.5 & 3.03 \\
\hline 4 & 5 & 0 & 9 & 0 & 4.5 & 4.5 & 3.51 \\
\hline 4 & 15 & 0 & 0 & 3 & 1.5 & 1.5 & 3.99 \\
\hline 5 & 1 & 1 & 1 & 1 & 1 & 10 & 3.16 \\
\hline 5 & 1 & 0 & 12 & 14 & 13 & 13 & 3.05 \\
\hline 5 & 2 & 2 & 0 & 0 & 0 & 100 & 2.16 \\
\hline 5 & 2 & 0 & 6 & 0 & 3 & 3 & 3.68 \\
\hline 5 & 3 & 0 & 2 & 0 & 1 & 1 & 4.16 \\
\hline 5 & 5 & 0 & 2 & 0 & 1 & 1 & 4.16 \\
\hline
\end{tabular}




\begin{tabular}{|c|c|c|c|c|c|c|c|}
\hline Date of Expt: & \multicolumn{7}{|l|}{$12 / 8 / 05$} \\
\hline Expt \#: & \multicolumn{7}{|l|}{97} \\
\hline Date read: & \multicolumn{7}{|l|}{$12 / 15 / 05$} \\
\hline WS: & \multicolumn{7}{|c|}{$\begin{array}{l}\text { V. cholerae grown in } 5: 1 \mathrm{IO}: \mathrm{NB} \text { for } 7 \text { days, then washed } \mathrm{X} 3 \mathrm{w} / \mathrm{IO} \text {, then } 1 \mathrm{x} \text { low speed } \\
\text { centrifugation, and resuspended in } 5: 1 \mathrm{IO}: \mathrm{NB}\end{array}$} \\
\hline & & \multicolumn{2}{|c|}{ Number of Colonies } & & \multirow[t]{2}{*}{ Colony Count } & & \\
\hline Specimen/QC & Dilution & \begin{tabular}{|l|l} 
Plate 1 \\
\end{tabular} & Plate 2 & ave count & & & \\
\hline QC open, hood & & 0 & & & 0 & & \\
\hline QC closed, hood & & 0 & & & 0 & & \\
\hline QC open, counter & & nd & & & nd & & \\
\hline dilution buffer & & 0 & & & 0 & & \\
\hline \begin{tabular}{|l|} 
Instant Ocean \\
\end{tabular} & & 0 & & & 0 & & \\
\hline \multicolumn{8}{|c|}{ all specs. w/ferrate stopped w/TS } \\
\hline & & & \multicolumn{2}{|c|}{ Number of Colonies } & & & \\
\hline Conc (mg/l) & $\begin{array}{l}\text { Time } \\
(\min )\end{array}$ & Dilution & \begin{tabular}{|l|} 
Plate 1 \\
\end{tabular} & Plate 2 & Ave. Count & Calc. Count & Log redctn. \\
\hline 0 & 0 & 6 & 0 & 0 & 0 & 100000 & $\mathrm{~N} / \mathrm{A}$ \\
\hline 0 & 0 & 4 & 1 & 3 & 2 & 20000 & $\mathrm{~N} / \mathrm{A}$ \\
\hline 0 & 0 & 3 & 16 & 13 & 14.5 & 14500 & $\mathrm{~N} / \mathrm{A}$ \\
\hline 0.5 & 1 & 3 & 0 & 1 & 0.5 & 500 & 0.30 \\
\hline 0.5 & 1 & 1 & 78 & 75 & 76.5 & 765 & 0.12 \\
\hline 0.5 & 2 & 3 & 0 & 0 & 0 & 1000 & 0.00 \\
\hline 0.5 & 2 & 1 & 49 & 52 & 50.5 & 505 & 0.30 \\
\hline 0.5 & 3 & 3 & 0 & 0 & 0 & 1000 & 0.00 \\
\hline 0.5 & 3 & 1 & 34 & 41 & 37.5 & 375 & 0.43 \\
\hline 0.5 & 5 & 3 & 0 & 0 & 0 & 1000 & 0.00 \\
\hline 0.5 & 5 & 1 & 26 & 15 & 20.5 & 205 & 0.69 \\
\hline 0.5 & 15 & 3 & 0 & 0 & 0 & 1000 & 0.00 \\
\hline 0.5 & 15 & 1 & 13 & 10 & 11.5 & 115 & 0.94 \\
\hline 0.5 & 30 & 2 & 3 & 1 & 2 & 200 & 0.70 \\
\hline 0.5 & 30 & 0 & awcg & $\mathrm{nd}$ & nd & $\mathrm{nd}$ & nd \\
\hline 1 & 1 & 3 & 0 & 0 & 0 & 1000 & 0.00 \\
\hline 1 & 1 & 1 & 22 & 17 & 19.5 & 195 & 0.71 \\
\hline 1 & 2 & 3 & 0 & 0 & 0 & 1000 & 0.00 \\
\hline 1 & 2 & 1 & 13 & 17 & 15 & 150 & 0.82 \\
\hline 1 & 3 & 3 & 0 & 0 & 0 & 1000 & 0.00 \\
\hline 1 & 3 & 1 & 0 & 9 & 4.5 & 45 & 1.35 \\
\hline 1 & 5 & 3 & 0 & 0 & 0 & 1000 & 0.00 \\
\hline 1 & 5 & 1 & 4 & 4 & 4 & 40 & 1.40 \\
\hline 1 & 15 & 3 & 0 & 0 & 0 & 1000 & 0.00 \\
\hline 1 & 15 & 1 & 1 & 5 & 3 & 30 & 1.52 \\
\hline 1 & 30 & 2 & 0 & 0 & 0 & 100 & 1.00 \\
\hline 1 & 30 & 0 & 16 & $\mathrm{nd}$ & 16 & 16 & 1.80 \\
\hline
\end{tabular}




\begin{tabular}{|c|c|c|c|c|c|c|c|}
\hline & & & Number of & Colonies & & & \\
\hline Conc (mg/l) & $\begin{array}{l}\text { Time } \\
\text { (min) }\end{array}$ & Dilution & Plate 1 & Plate 2 & $\begin{array}{l}\text { Ave. } \\
\text { Count }\end{array}$ & $\begin{array}{l}\text { Calc. } \\
\text { Count } \\
\end{array}$ & $\begin{array}{l}\text { Log } \\
\text { redctn. }\end{array}$ \\
\hline 2.5 & 1 & 3 & 0 & 0 & 0 & 1000 & 0.00 \\
\hline 2.5 & 1 & 1 & 7 & 9 & 8 & 80 & 1.10 \\
\hline 2.5 & 2 & 3 & 0 & 0 & 0 & 1000 & 0.00 \\
\hline 2.5 & 2 & 1 & 4 & 8 & 6 & 60 & 1.22 \\
\hline 2.5 & 3 & 2 & 0 & 0 & 0 & 100 & 1.00 \\
\hline 2.5 & 3 & 0 & 18 & awcg & 18 & 18 & 1.74 \\
\hline 2.5 & 5 & 2 & 0 & 0 & 0 & 100 & 1.00 \\
\hline 2.5 & 5 & 0 & 5 & 7 & 6 & 6 & 2.22 \\
\hline 2.5 & 15 & 2 & 0 & 0 & 0 & 100 & 1.00 \\
\hline 2.5 & 15 & 0 & 2 & 6 & 4 & 4 & 2.40 \\
\hline 2.5 & 30 & 1 & 0 & 0 & 0 & 10 & 2.00 \\
\hline 2.5 & 30 & 0 & 0 & 0 & 0 & 1 & 3.00 \\
\hline 4 & 1 & 2 & 0 & 0 & 0 & 100 & 1.00 \\
\hline 4 & 1 & 0 & 11 & 10 & 10.5 & 10.5 & 1.98 \\
\hline 4 & 2 & 2 & 0 & 0 & 0 & 100 & 1.00 \\
\hline 4 & 2 & 0 & 6 & 1 & 3.5 & 3.5 & 2.46 \\
\hline 4 & 3 & 1 & 0 & 0 & 0 & 10 & 2.00 \\
\hline 4 & 3 & 0 & 4 & 2 & 3 & 3 & 2.52 \\
\hline 4 & 5 & 0 & 3 & 0 & 1.5 & 1.5 & 2.82 \\
\hline 4 & 15 & 0 & 0 & 0 & 0 & 1 & 3.00 \\
\hline 5 & 1 & 2 & 1 & 0 & 0.5 & 50 & 1.30 \\
\hline 5 & 1 & 0 & 21 & awcg & 21 & 21 & 1.68 \\
\hline 5 & 2 & 2 & 0 & 0 & 0 & 100 & 1.00 \\
\hline 5 & 2 & 0 & 11 & 9 & 10 & 10 & 2.00 \\
\hline 5 & 3 & 0 & 2 & 0 & 1 & 1 & 3.00 \\
\hline 5 & 5 & 0 & 0 & 1 & 0.5 & 0.5 & 3.30 \\
\hline
\end{tabular}




\section{E.5 Experiments on Effect of $\mathrm{N}_{0}$}

\begin{tabular}{|l|l|}
\hline Expt. \#: & 43 \\
\hline Date of Expt.: & $5 / 13 / 2005$ \\
\hline $\begin{array}{l}\text { Date HPC } \\
\text { read: }\end{array}$ & $5 / 17 / 2005$ \\
\hline Purpose: & Investigate effect of $\mathrm{N}_{0}$ on disinfection w/2 mg/l ferrate \\
\hline WS: & $\begin{array}{l}\text { E Coli in IO:NB, } 600 \mathrm{mls} \text { as a } 5: 1 \text { dilution, grown for } 2 \text { days on shaker } \\
\text { table at RT, then spun and resuspended in } 5: 1 \text { IO:dH2O }\end{array}$ \\
\hline
\end{tabular}

\begin{tabular}{|c|c|c|c|c|c|}
\hline \multicolumn{6}{|c|}{ Heterotrophic Plate Count } \\
\hline & & $\begin{array}{l}\text { Number of } \\
\text { Colonies }\end{array}$ & & & \\
\hline Specimen/QC & $\begin{array}{l}\text { Dilution } \\
\left(10^{\wedge}-n\right)\end{array}$ & Plate 1 & $\begin{array}{l}\text { Plat } \\
\text { e } 2\end{array}$ & $\begin{array}{l}\text { ave } \\
\text { count }\end{array}$ & $\begin{array}{l}\text { Colony } \\
\text { Count }\end{array}$ \\
\hline QC open, hood & & 0 & & & 0 \\
\hline QC closed, hood & & 0 & & & 0 \\
\hline QC open, counter & & 5 & & & 5 \\
\hline dilution buffer & & 0 & & & 0 \\
\hline Instant Ocean & & nd & & & nd \\
\hline \multicolumn{6}{|c|}{$\begin{array}{l}\text { all specs. w/ferrate stopped w/TS; all } \\
\text { concs. are } 2 \mathrm{mg} / \mathrm{I}\end{array}$} \\
\hline & & & & & \\
\hline WS 0' & 6 & 28 & 32 & 30 & $\begin{array}{r}3.00 \mathrm{E}+0 \\
7 \\
\end{array}$ \\
\hline WS 0' & 7 & 3 & 2 & 2.5 & $\begin{array}{r}2.50 \mathrm{E}+0 \\
7\end{array}$ \\
\hline $\mathrm{N}_{0}, 15^{\prime}$ & 1 & 118 & 125 & $\begin{array}{r}121 . \\
5 \\
\end{array}$ & $\begin{array}{r}1.22 \mathrm{E}+0 \\
3\end{array}$ \\
\hline $\mathrm{N}_{0}, 30^{\prime}$ & 1 & 9 & 10 & 9.5 & $\begin{array}{r}9.50 \mathrm{E}+0 \\
1\end{array}$ \\
\hline $1: 10 \mathrm{~N}_{0}, 15^{\prime}$ & $1,1 \mathrm{ml}$ & 0 & 0 & 0 & $\begin{array}{r}0.00 \mathrm{E}+0 \\
0 \\
\end{array}$ \\
\hline $1: 10 N_{0}, 30^{\prime}$ & $1,1 \mathrm{ml}$ & 0 & 0 & 0 & $\begin{array}{r}0.00 \mathrm{E}+0 \\
0 \\
\end{array}$ \\
\hline $1: 100 N_{0}, 15^{\prime}$ & $1,1 \mathrm{ml}$ & 0 & 0 & 0 & $\begin{array}{r}0.00 \mathrm{E}+0 \\
0\end{array}$ \\
\hline $1: 100 \mathrm{~N}_{0}, 30 '$ & $1,1 \mathrm{ml}$ & 0 & 0 & 0 & $\begin{array}{r}0.00 \mathrm{E}+0 \\
0 \\
\end{array}$ \\
\hline $1: 1000 N_{0}, 15^{\prime}$ & $1,1 \mathrm{ml}$ & 0 & 0 & 0 & $\begin{array}{r}0.00 \mathrm{E}+0 \\
0\end{array}$ \\
\hline $1: 1000 \mathrm{~N}_{0}, 30^{\prime}$ & $1,1 \mathrm{ml}$ & 0 & 0 & 0 & $\begin{array}{r}0.00 \mathrm{E}+0 \\
0 \\
\end{array}$ \\
\hline
\end{tabular}




\begin{tabular}{|l|l|}
\hline Expt. \#: & 48 \\
\hline Date of Expt.: & $6 / 1 / 2005$ \\
\hline Date HPC read: & $6 / 6 / 2005$ \\
\hline Purpose: & Effect of $\mathrm{N}_{0}$ on effectiveness of 2 mg/l ferrate on K. pneumoniae \\
\hline WS: & $\begin{array}{l}\text { K. pneumoniae in IO:NB, } 600 \text { mls as a } 5: 1 \text { dilution, grown for } 4 \text { days on } \\
\text { shaker table at RT, then spun and resuspended in 5:1 IO:dH2O }\end{array}$ \\
\hline
\end{tabular}

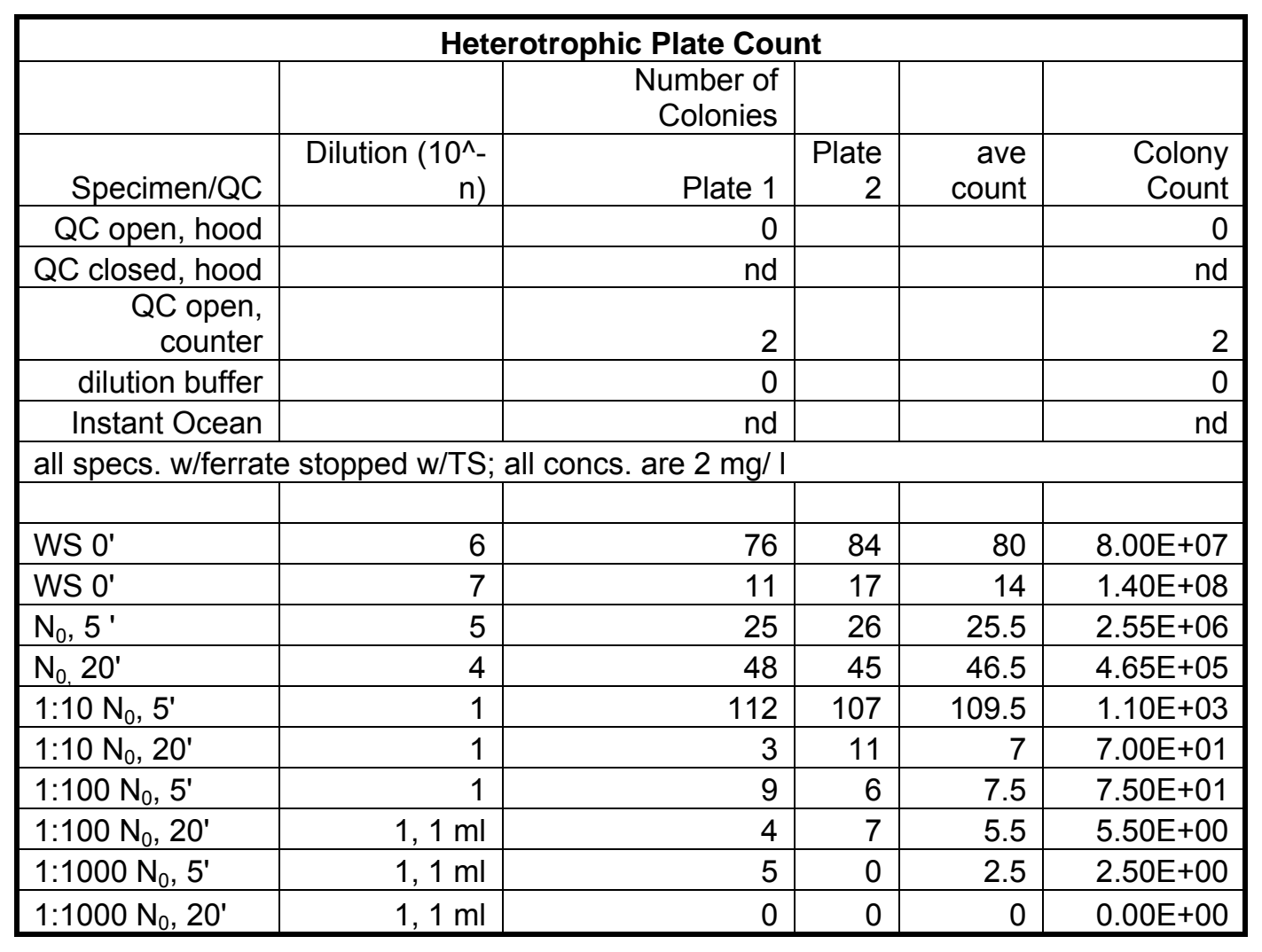




\begin{tabular}{|l|l|}
\hline Expt. \#: & 52 \\
\hline Date of Expt.: & $6 / 7 / 2005$ \\
\hline Date HPC read: & $6 / 12 / 2005$ \\
\hline Purpose: & Investigate effect of $\mathrm{N}_{0}$ on disinfection w/1.5 mg/l ferrate \\
\hline WS: & $\begin{array}{l}\text { E Coli in IO:NB, } 600 \text { mls as a } 5: 1 \text { dilution, grown for } 4 \text { days on shaker table at RT, } \\
\text { then spun and resuspended in 5:1 IO:dH2O }\end{array}$ \\
\hline
\end{tabular}

\begin{tabular}{|c|c|c|c|c|c|}
\hline & & $\begin{array}{l}\text { Number } \\
\text { of } \\
\text { Colonie } \\
\mathrm{s}\end{array}$ & & & \\
\hline Specimen/QC & $\begin{array}{l}\text { Dilution } \\
\left(10^{\wedge}-n\right) \\
\end{array}$ & Plate 1 & $\begin{array}{l}\text { Plate } \\
2\end{array}$ & $\begin{array}{l}\text { ave } \\
\text { count }\end{array}$ & $\begin{array}{l}\text { Colony } \\
\text { Count }\end{array}$ \\
\hline QC open, hood & & 0 & & & 0 \\
\hline QC closed, hood & & nd & & & nd \\
\hline QC open, counter & & 3 & & & 3 \\
\hline dilution buffer & & 0 & & & 0 \\
\hline Instant Ocean & & nd & & & nd \\
\hline \multicolumn{6}{|c|}{$\begin{array}{l}\text { all specs. w/ferrate stopped w/TS; all } \\
\text { concs. are } 1.5 \mathrm{mg} / \mathrm{I}\end{array}$} \\
\hline WS 0' & 6 & 53 & 51 & 52 & $5.20 \mathrm{E}+07$ \\
\hline WS 0' & 7 & 6 & 5 & 5.5 & $5.50 \mathrm{E}+07$ \\
\hline $\mathrm{N}_{0}, 10^{\prime}$ & 3 & 160 & 175 & 167.5 & $1.68 \mathrm{E}+05$ \\
\hline $\mathrm{N}_{0}, 20^{\prime}$ & 3 & 11 & 10 & 10.5 & $1.05 E+04$ \\
\hline $1: 10 \mathrm{~N}_{0}, 10^{\prime}$ & $1,1 \mathrm{ml}$ & 2 & awcg & 2 & $2.00 E+00$ \\
\hline $1: 10 \mathrm{~N}_{0}, 20^{\prime}$ & $1,1 \mathrm{ml}$ & 0 & 0 & 0 & $0.00 \mathrm{E}+00$ \\
\hline $1: 100 \mathrm{~N}_{0}, 10^{\prime}$ & $1,1 \mathrm{ml}$ & 1 & 1 & 1 & $1.00 \mathrm{E}+00$ \\
\hline $1: 100 \mathrm{~N}_{0}, 20$ & $1,1 \mathrm{ml}$ & 0 & 1 & 0.5 & 5.00E-01 \\
\hline $1: 1000 \mathrm{~N}_{0}, 10^{\prime}$ & $1,1 \mathrm{ml}$ & 0 & 0 & 0 & $0.00 \mathrm{E}+00$ \\
\hline $1: 1000 \mathrm{~N}_{0}, 20$ & $1,1 \mathrm{ml}$ & 0 & 0 & 0 & $0.00 \mathrm{E}+00$ \\
\hline
\end{tabular}




\begin{tabular}{|l|l|}
\hline Expt. \#: & 54 \\
\hline Date of Expt.: & $6 / 15 / 2005$ \\
\hline Date HPC read: & $6 / 21 / 2005$ \\
\hline Purpose: & Investigate effect of $\mathrm{N}_{0}$ on disinfection w/0.5 mg/l ferrate \\
\hline WS: & $\begin{array}{l}\text { E Coli in IO:NB, } 600 \text { mls as a } 5: 1 \text { dilution, grown for } 4 \text { days on shaker table at RT, } \\
\text { then spun and resuspended in 5:1 IO:dH2O }\end{array}$ \\
\hline
\end{tabular}

\begin{tabular}{|c|c|c|c|c|c|}
\hline \multicolumn{6}{|c|}{ Heterotrophic Plate Count } \\
\hline & & $\begin{array}{l}\text { Number of } \\
\text { Colonies }\end{array}$ & & & \\
\hline Specimen/QC & $\begin{array}{l}\text { Dilution } \\
\left(10^{\wedge}-n\right)\end{array}$ & Plate 1 & $\begin{array}{l}\text { Plat } \\
\text { e } 2\end{array}$ & $\begin{array}{l}\text { ave } \\
\text { coun } \\
\mathrm{t}\end{array}$ & $\begin{array}{l}\text { Colony } \\
\text { Count }\end{array}$ \\
\hline QC open, hood & & 0 & & & 0 \\
\hline QC closed, hood & & nd & & & nd \\
\hline QC open, counter & & 7 & & & 7 \\
\hline dilution buffer & & 0 & & & 0 \\
\hline Instant Ocean & & nd & & & nd \\
\hline \multicolumn{6}{|c|}{$\begin{array}{l}\text { all specs. w/ferrate stopped w/TS; all } \\
\text { concs. are } 0.5 \mathrm{mg} / \mathrm{I}\end{array}$} \\
\hline & & & & & \\
\hline WS 0' & 6 & 34 & 30 & 32 & $\begin{array}{r}3.20 \mathrm{E}+0 \\
7\end{array}$ \\
\hline WS 0' & 7 & 1 & 5 & 3 & $\begin{array}{r}3.00 \mathrm{E}+0 \\
7\end{array}$ \\
\hline $\mathrm{N}_{0}, 5^{\prime}$ & 2 & 104 & 99 & $\begin{array}{r}101 . \\
5 \\
\end{array}$ & $\begin{array}{r}1.02 \mathrm{E}+0 \\
4 \\
\end{array}$ \\
\hline $\mathrm{N}_{0}, 1^{\prime}$ & 2 & 80 & 76 & 78 & $\begin{array}{r}7.80 \mathrm{E}+0 \\
3 \\
\end{array}$ \\
\hline $1: 10 N_{0}, 5^{\prime}$ & 1 & 102 & 93 & 97.5 & $\begin{array}{r}9.75 \mathrm{E}+0 \\
2\end{array}$ \\
\hline $1: 10 \mathrm{~N}_{0}, 15^{\prime}$ & 1 & 8 & 20 & 14 & $\begin{array}{r}1.40 \mathrm{E}+0 \\
2 \\
\end{array}$ \\
\hline $1: 100 \mathrm{~N}_{0}, 5^{\prime}$ & 1 & 4 & 3 & 3.5 & $\begin{array}{r}3.50 \mathrm{E}+0 \\
1 \\
\end{array}$ \\
\hline $1: 100 \mathrm{~N}_{0}, 15^{\prime}$ & 1 & 3 & 1 & 2 & $\begin{array}{r}2.00 \mathrm{E}+0 \\
1 \\
\end{array}$ \\
\hline $1: 1000 \mathrm{~N}_{0}, 5^{\prime}$ & $1,1 \mathrm{ml}$ & 6 & 3 & 4.5 & $\begin{array}{r}4.50 \mathrm{E}+0 \\
0 \\
\end{array}$ \\
\hline $1: 1000 \mathrm{~N}_{0}, 15^{\prime}$ & $1,1 \mathrm{ml}$ & 0 & 0 & 0 & $\begin{array}{r}0.00 \mathrm{E}+0 \\
0 \\
\end{array}$ \\
\hline
\end{tabular}




\begin{tabular}{|l|l|}
\hline Expt. \#: & 57 \\
\hline Date of Expt.: & $6 / 17 / 2005$ \\
\hline Date HPC read: & $6 / 23 / 2005$ \\
\hline Purpose: & Effect of $\mathrm{N}_{0}$ on effectiveness of $1 \mathrm{mg} / \mathrm{l}$ ferrate on K. pneumoniae \\
\hline WS: & $\begin{array}{l}\text { K. pneumoniae in IO:NB, } 600 \mathrm{mls} \text { as a } 5: 1 \text { dilution, grown for } 4 \text { days on } \\
\text { shaker table at RT, spun, washed, and resuspended in 5:1 IO:dH2O }\end{array}$ \\
\hline
\end{tabular}

\begin{tabular}{|c|c|c|c|c|c|}
\hline & Heterotrop & $\begin{array}{l}\text { ic Plat } \\
\text { Num } \\
\text { Col }\end{array}$ & $\begin{array}{l}\text { Count } \\
\text { r of } \\
\text { ies }\end{array}$ & & \\
\hline & & Plate & Plate & & \\
\hline Specimen/QC & Dilution $\left(10^{\wedge}-n\right)$ & 1 & 2 & ave count & Colony Count \\
\hline QC open, hood & & 0 & & & 0 \\
\hline QC closed, hood & & nd & & & nd \\
\hline QC open, counter & & 4 & & & 4 \\
\hline dilution buffer & & 0 & & & 0 \\
\hline Instant Ocean & & nd & & & nd \\
\hline all specs. w/ferrate st & ped w/TS; all con & are 2 & $\mathrm{gg} / \mathrm{I}$ & & \\
\hline WS 0' & 6 & 53 & 52 & 52.5 & $5.25 E+07$ \\
\hline WS 0' & 7 & 5 & 3 & 4 & $4.00 E+07$ \\
\hline $\mathrm{N}_{0}, 5^{\prime}$ & 3 & 508 & 476 & 492 & $4.92 E+05$ \\
\hline $\mathrm{N}_{0}, 10^{\prime}$ & 3 & 33 & 34 & 33.5 & $3.35 E+04$ \\
\hline $1: 10 \mathrm{~N}_{0}, 5^{\prime}$ & 1 & 42 & awcg & 42 & $4.20 E+02$ \\
\hline $1: 10 \mathrm{~N}_{0}, 10^{\prime}$ & 1 & 15 & 24 & 19.5 & $1.95 E+02$ \\
\hline $1: 100 \mathrm{~N}_{0}, 5^{\prime}$ & 1 & 3 & 4 & 3.5 & $3.50 E+01$ \\
\hline $1: 100 N_{0}, 10^{\prime}$ & $1,1 \mathrm{ml}$ & 2 & 2 & 2 & $2.00 E+00$ \\
\hline $1: 1000 \mathrm{~N}_{0}, 5^{\prime}$ & $1,1 \mathrm{ml}$ & 3 & 0 & 1.5 & $1.50 \mathrm{E}+00$ \\
\hline $1: 1000 \mathrm{~N}_{0}, 10^{\prime}$ & $1,1 \mathrm{ml}$ & 0 & 0 & 0 & $0.00 E+00$ \\
\hline
\end{tabular}




\section{E.6 Experiments on Procedure Optimization}

\section{E.6.1 Effect of Delay in Processing}

\begin{tabular}{|c|c|c|c|c|c|c|c|c|c|}
\hline $\begin{array}{l}\text { Date of } \\
\text { Expt: }\end{array}$ & \multicolumn{9}{|l|}{$7 / 15 / 2005$} \\
\hline Expt \#: & \multicolumn{9}{|l|}{66} \\
\hline Date read: & \multicolumn{9}{|c|}{$7 / 16 / 2005$} \\
\hline Purpose: & \multicolumn{9}{|c|}{ Evaluate any effect on delay in processing } \\
\hline WS: & \multicolumn{9}{|c|}{$\begin{array}{l}\text { E.coli grown in } 5: 1 \mathrm{IO} \text { :NB for } 5 \text { days, then spun, washed } \mathrm{X} 3 \text { and resuspended in } 5: 1 \\
\mathrm{IO} / \mathrm{diH} 2 \mathrm{O}\end{array}$} \\
\hline \multirow[b]{2}{*}{ Conc.(mg/l) } & \multirow[b]{2}{*}{$\begin{array}{l}\text { time } \\
(\min )\end{array}$} & \multirow[b]{2}{*}{ dilution } & \multirow[b]{2}{*}{$\begin{array}{l}\mathrm{lg} \\
\text { wls } \\
\text { pos }\end{array}$} & \multirow[b]{2}{*}{$\begin{array}{l}\text { sm } \\
\text { wls } \\
\text { pos }\end{array}$} & \multirow[b]{2}{*}{$\begin{array}{l}\text { MPN/ } \\
100 \mathrm{ml}\end{array}$} & \multirow[b]{2}{*}{$\mathrm{MPN} / \mathrm{ml}$} & \multirow[b]{2}{*}{$\begin{array}{l}\text { calc } \\
\mathrm{MPN} / \mathrm{ml}\end{array}$} & \multirow[b]{2}{*}{ Condition } & \multirow[b]{2}{*}{$\begin{array}{l}\log \\
\text { redctn. }\end{array}$} \\
\hline & & & & & & & & & \\
\hline 0 & 0 & 3 & 49 & 48 & $>2419.6$ & $>24.2$ & $>24.2$ & 1 & $\mathrm{~N} / \mathrm{A}$ \\
\hline 0 & 0 & 7 & 48 & 18 & 248.9 & 24890000 & 24890000 & I & $\mathrm{N} / \mathrm{A}$ \\
\hline 0 & 0 & 5 & 49 & 48 & $>2419.6$ & $>24.2$ & $>24.2$ & 1 & $\mathrm{~N} / \mathrm{A}$ \\
\hline 0.75 & 1 & 2 & 49 & 47 & 2419.6 & 2419.6 & 2419.6 & I & 4.01 \\
\hline 0.75 & 1 & 5 & 14 & 2 & 18.5 & 18500 & 18500 & I & 3.13 \\
\hline 0.75 & 5 & 1 & 49 & 48 & $>2419.6$ & $>24.2$ & $>24.2$ & 1 & $\mathrm{~N} / \mathrm{A}$ \\
\hline 0.75 & 5 & 3 & 49 & 29 & 579.4 & 5794 & 5794 & I & 3.63 \\
\hline 0.75 & 15 & 1 & 49 & 48 & $>2419.6$ & $>24.2$ & $>24.2$ & 1 & $\mathrm{~N} / \mathrm{A}$ \\
\hline 0.75 & 15 & 3 & 48 & 19 & 260.3 & 2603 & 2603 & I & 3.98 \\
\hline 1.5 & 1 & 1 & 49 & 48 & $>2419.6$ & $>24.2$ & $>24.2$ & 1 & $\mathrm{~N} / \mathrm{A}$ \\
\hline 1.5 & 1 & 4 & 5 & 0 & 5.2 & 520 & 520 & I & 4.68 \\
\hline 1.5 & 5 & 1 & 49 & 48 & $>2419.6$ & $>24.2$ & $>24.2$ & I & $\mathrm{N} / \mathrm{A}$ \\
\hline 1.5 & 5 & 3 & 12 & 1 & 14.6 & 146 & 146 & I & 5.23 \\
\hline 1.5 & 15 & 1 & 49 & 42 & 1299.7 & 129.97 & 129.97 & 1 & 5.28 \\
\hline 0 & 0 & 7 & 48 & 16 & 218.7 & 21870000 & 21870000 & W & 0.06 \\
\hline 0 & 0 & 5 & 49 & 48 & $>2419.6$ & $>24.2$ & $>24.2$ & W & $\mathrm{N} / \mathrm{A}$ \\
\hline 0.75 & 1 & 2 & 49 & 48 & $>2419.6$ & $>24.2$ & $>24.2$ & W & $\mathrm{N} / \mathrm{A}$ \\
\hline 0.75 & 1 & 5 & 20 & 2 & 27.5 & 27500 & 27500 & W & 2.96 \\
\hline 0.75 & 5 & 1 & 49 & 48 & $>2419.6$ & $>24.2$ & $>24.2$ & W & $\mathrm{N} / \mathrm{A}$ \\
\hline 0.75 & 5 & 3 & 48 & 24 & 328.2 & 3282 & 3282 & W & 3.88 \\
\hline 0.75 & 15 & 1 & 49 & 48 & $>2419.6$ & $>24.2$ & $>24.2$ & W & N/A \\
\hline 0.75 & 15 & 3 & 45 & 37 & 312.3 & 3123 & 3123 & W & 3.90 \\
\hline 1.5 & 1 & 1 & 49 & 48 & $>2419.6$ & $>24.2$ & $>24.2$ & W & $\mathrm{N} / \mathrm{A}$ \\
\hline 1.5 & 1 & 4 & 2 & 0 & 2 & 200 & 200 & W & 5.09 \\
\hline 1.5 & 5 & 1 & 49 & 48 & $>2419.6$ & $>24.2$ & $>24.2$ & W & $\mathrm{N} / \mathrm{A}$ \\
\hline 1.5 & 5 & 3 & 10 & 0 & 11 & 110 & 110 & W & 5.35 \\
\hline 1.5 & 15 & 1 & 49 & 42 & 1299.7 & 129.97 & 129.97 & W & 5.28 \\
\hline
\end{tabular}




\section{E.6.2 Experiments on Effect of Stirring}

\begin{tabular}{|l|l|}
\hline Expt. \#: & 47 \\
\hline Date of Expt.: & $5 / 25 / 2005$ \\
\hline Date HPC read: & $5 / 30 / 2005$ \\
\hline Purpose: & Investigate effect of stirring on disinfection w/2 mg/l ferrate \\
\hline WS: & $\begin{array}{l}\text { E Coli in IO:NB, } 600 \text { mls as a } 5: 1 \text { dilution, grown for } 4 \text { days on shaker table at RT, } \\
\text { then spun and resuspended in 5:1 IO:dH2O }\end{array}$ \\
\hline
\end{tabular}

\begin{tabular}{|c|c|c|c|c|c|}
\hline \multicolumn{6}{|c|}{ Heterotrophic Plate Count } \\
\hline & & $\begin{array}{l}\text { Number of } \\
\text { Colonies }\end{array}$ & & & \\
\hline Specimen/QC & $\begin{array}{l}\text { Dilution } \\
\left(10^{\wedge}-n\right)\end{array}$ & Plate 1 & $\begin{array}{l}\text { Plat } \\
\text { e } 2\end{array}$ & $\begin{array}{l}\text { ave } \\
\text { coun } \\
t\end{array}$ & $\begin{array}{l}\text { Colony } \\
\text { Count }\end{array}$ \\
\hline QC open, hood & & 0 & & & 0 \\
\hline QC closed, hood & & nd & & & nd \\
\hline QC open, counter & & 2 & & & 2 \\
\hline dilution buffer & & nd & & & nd \\
\hline Instant Ocean & & 0 & & & 0 \\
\hline \multicolumn{6}{|c|}{$\begin{array}{l}\text { all specs. w/ferrate stopped w/TS; all } \\
\text { concs. are } 1.5 \mathrm{mg} / \mathrm{l}\end{array}$} \\
\hline & & & & & \\
\hline WS $0^{\prime}$ & 6 & 53 & 54 & 53.5 & $\begin{array}{r}5.35 \mathrm{E}+0 \\
7\end{array}$ \\
\hline WS 0' & 7 & 8 & 4 & 6 & $\begin{array}{r}6.00 \mathrm{E}+0 \\
7 \\
\end{array}$ \\
\hline NS $5^{\prime}$ & 4 & 29 & 30 & 29.5 & $\begin{array}{r}2.95 \mathrm{E}+0 \\
5\end{array}$ \\
\hline NS 15' & 1 & 15 & 15 & 15 & $\begin{array}{r}1.50 \mathrm{E}+0 \\
2\end{array}$ \\
\hline MS 5' & 1 & 5 & 2 & 3.5 & $\begin{array}{r}3.50 \mathrm{E}+0 \\
1\end{array}$ \\
\hline MS 15' & $1,1 \mathrm{ml}$ & 1 & 1 & 1 & $\begin{array}{r}1.00 \mathrm{E}+0 \\
0 \\
\end{array}$ \\
\hline VS 5' & $1,1 \mathrm{ml}$ & 0 & 2 & 1 & $\begin{array}{r}1.00 \mathrm{E}+0 \\
0\end{array}$ \\
\hline VS $15^{\prime}$ & $1,1 \mathrm{ml}$ & 0 & 0 & 0 & $\begin{array}{r}0.00 \mathrm{E}+0 \\
0\end{array}$ \\
\hline
\end{tabular}




\begin{tabular}{|l|l|}
\hline Expt. \#: & 50 \\
\hline Date of Expt.: & $6 / 1 / 2005$ \\
\hline Date HPC read: & $6 / 6 / 2005$ \\
\hline Purpose: & Investigate effect of stirring on disinfection of K. pneumoniae w/2 mg/l ferrate \\
\hline WS: & $\begin{array}{l}\text { K. pneumoniae in IO:NB, } 600 \text { mls as a } 5: 1 \text { dilution, grown for } 3 \text { days on } \\
\text { shaker table at RT, then spun and resuspended in } 100 \mathrm{mls} 5: 1 \text { IO:dH2O }\end{array}$ \\
\hline
\end{tabular}

\begin{tabular}{|c|c|c|c|c|c|}
\hline \multicolumn{6}{|c|}{ Heterotrophic Plate Count } \\
\hline & & $\begin{array}{l}\text { Number of } \\
\text { Colonies }\end{array}$ & & & \\
\hline Specimen/QC & $\begin{array}{l}\text { Dilution } \\
\left(10^{\wedge}-n\right)\end{array}$ & Plate 1 & $\begin{array}{l}\text { Plat } \\
\text { e } 2\end{array}$ & $\begin{array}{l}\text { ave } \\
\text { coun } \\
t \\
\end{array}$ & $\begin{array}{l}\text { Colony } \\
\text { Count }\end{array}$ \\
\hline QC open, hood & & 0 & & & 0 \\
\hline QC closed, hood & & nd & & & nd \\
\hline QC open, counter & & 2 & & & 2 \\
\hline dilution buffer & & 0 & & & 0 \\
\hline Instant Ocean & & nd & & & nd \\
\hline \multicolumn{6}{|c|}{$\begin{array}{l}\text { all specs. w/ferrate stopped w/TS; all } \\
\text { concs. are } 2 \mathrm{mg} / \mathrm{l} \text { ferrate }\end{array}$} \\
\hline & & & & & \\
\hline WS 0' & 5 & 120 & 94 & 107 & $\begin{array}{r}1.07 \mathrm{E}+0 \\
7 \\
\end{array}$ \\
\hline WS 0' & 6 & 17 & 26 & 21.5 & $\begin{array}{r}2.15 \mathrm{E}+0 \\
7\end{array}$ \\
\hline NS $5^{\prime}$ & 4 & 31 & 30 & 30.5 & $\begin{array}{r}3.05 E+0 \\
5\end{array}$ \\
\hline NS $15^{\prime}$ & 3 & 13 & 18 & 15.5 & $\begin{array}{r}1.55 \mathrm{E}+0 \\
4 \\
\end{array}$ \\
\hline MS 5' & 2 & 153 & 139 & 146 & $\begin{array}{r}1.46 \mathrm{E}+0 \\
4 \\
\end{array}$ \\
\hline MS 15' & 1 & 25 & 22 & 23.5 & $\begin{array}{r}2.35 \mathrm{E}+0 \\
2\end{array}$ \\
\hline VS $5^{\prime}$ & 2 & 33 & 36 & 34.5 & $\begin{array}{r}3.45 E+0 \\
3\end{array}$ \\
\hline VS $15^{\prime}$ & 1 & 25 & 28 & 26.5 & $\begin{array}{r}2.65 \mathrm{E}+0 \\
2\end{array}$ \\
\hline
\end{tabular}




\section{E.6.3 Experiment on Effect of Washing}

\begin{tabular}{|c|c|c|c|c|c|c|}
\hline Expt. \#: & \multicolumn{6}{|l|}{55} \\
\hline Date of Expt:: & \multicolumn{6}{|l|}{$6 / 17 / 2005$} \\
\hline $\begin{array}{l}\text { Date HPC } \\
\text { read: }\end{array}$ & \multicolumn{6}{|l|}{$6 / 19 / 2005$} \\
\hline Purpose: & \multicolumn{6}{|c|}{ Effect of washing on effectiveness of $1 \mathrm{mg} / \mathrm{l}$ ferrate on $\mathrm{K}$. pneumoniae } \\
\hline WS: & \multicolumn{6}{|c|}{$\begin{array}{l}\text { K. pneumoniae in IO:NB, } 600 \text { mls as a } 5: 1 \text { dilution, grown for } 5 \text { days on shaker } \\
\text { table at RT, spun, washed, and resuspended in } 5: 1 \text { IO:dH2O }\end{array}$} \\
\hline Condition & WS (MPN) & dilution & MPN & $5^{\prime}(\mathrm{MPN})$ & dilution & MPN \\
\hline 1X wash & 1732.9 & 6 & $1.73 \mathrm{E}+07$ & 4.1 & 7 & 4.10E+05 \\
\hline $2 \mathrm{X}$ wash & 1119.9 & 6 & $1.12 \mathrm{E}+07$ & 30.5 & 4 & $3.05 \mathrm{E}+03$ \\
\hline $3 \mathrm{X}$ wash & 629.4 & 6 & $6.29 \mathrm{E}+06$ & 18.9 & 4 & $1.89 \mathrm{E}+03$ \\
\hline
\end{tabular}




\section{E.7 Regrowth Experiments}

\begin{tabular}{|c|c|c|c|c|c|c|c|c|}
\hline $\begin{array}{l}\text { Date of } \\
\text { Expt: }\end{array}$ & \multicolumn{8}{|c|}{$7 / 28 / 2005$} \\
\hline Expt \#: & \multicolumn{8}{|c|}{90} \\
\hline Date read: & \multicolumn{8}{|c|}{$7 / 29 / 2005$} \\
\hline Purpose: & \multicolumn{8}{|c|}{ Regrowth of E. coli after ferrate disinfection } \\
\hline WS: & \multicolumn{8}{|c|}{$\begin{array}{l}\text { E.coli grown in 5:1 IO:NB for } 4 \text { days,spun, washed } X 3 \text { and resuspended in 5:1 } \\
\text { IO/diH2O }\end{array}$} \\
\hline Conc.(mg/l) & $\begin{array}{l}\text { time } \\
(\min )\end{array}$ & dilution & $\begin{array}{l}\lg \text { wls } \\
\text { pos }\end{array}$ & $\begin{array}{l}\text { sm wls } \\
\text { pos }\end{array}$ & $\begin{array}{l}\text { MPN/ } \\
100 \mathrm{ml}\end{array}$ & $\mathrm{MPN} / \mathrm{ml}$ & $\begin{array}{l}\text { calc } \\
\mathrm{MPN} / \mathrm{ml}\end{array}$ & $\begin{array}{l}\text { log } \\
\text { redctn. }\end{array}$ \\
\hline 0 & $15 \mathrm{~min}$ & 3 & 49 & 48 & nd & nd & nd & nd \\
\hline 0 & $15 \mathrm{~min}$ & 7 & 3 & 0 & 3.1 & 310000 & 310000 & $\mathrm{~N} / \mathrm{A}$ \\
\hline 0 & $15 \min$ & 5 & 48 & 15 & 218.7 & 218700 & 218700 & $\mathrm{~N} / \mathrm{A}$ \\
\hline 5 & $15 \mathrm{~min}$ & 1 & 47 & 10 & 160.7 & 16.07 & 16.07 & 4.13 \\
\hline 5 & $15 \mathrm{~min}$ & 3 & 3 & 0 & 3.1 & 31 & 31 & 3.85 \\
\hline 10 & $15 \min$ & 1 & 0 & 0 & 0 & 0 & 0.1 & 6.34 \\
\hline 0 & $48 \mathrm{hr}$ & 4 & 49 & 39 & 1046.2 & 104620 & 104620 & 0.32 \\
\hline 0 & $48 \mathrm{hr}$ & 7 & 1 & 0 & 1 & 100000 & 100000 & 0.34 \\
\hline $0+$ glu & $48 \mathrm{hr}$ & 5 & 48 & 28 & 396.8 & 396800 & 396800 & -0.26 \\
\hline $0+$ glu & $48 \mathrm{hr}$ & 8 & 0 & 0 & 0 & 0 & 1000000 & -0.66 \\
\hline 5 & $48 \mathrm{hr}$ & 1 & 5 & 0 & 5.2 & 0.52 & 0.52 & 5.62 \\
\hline 5 & $48 \mathrm{hr}$ & 3 & 0 & 0 & 0 & 0 & 10 & 4.34 \\
\hline $5+$ glu & $48 \mathrm{hr}$ & 1 & 29 & 3 & 46.4 & 4.64 & 4.64 & 4.67 \\
\hline $5+$ glu & $48 \mathrm{hr}$ & 3 & 0 & 0 & 0 & 0 & 10 & 4.34 \\
\hline 10 & $48 \mathrm{hr}$ & 1 & 0 & 0 & 0 & 0 & 0.1 & 6.34 \\
\hline $10+$ glu & $48 \mathrm{hr}$ & 1 & 0 & 0 & 0 & 0 & 0.1 & 6.34 \\
\hline
\end{tabular}




\begin{tabular}{|c|c|c|c|c|c|c|c|c|}
\hline $\begin{array}{l}\text { Date of } \\
\text { Expt: }\end{array}$ & \multicolumn{8}{|c|}{$7 / 28 / 2005$} \\
\hline Expt \#: & \multicolumn{8}{|c|}{91} \\
\hline Date read: & \multicolumn{8}{|c|}{$7 / 29 / 2005$} \\
\hline Purpose: & \multicolumn{8}{|c|}{ Regrowth of E. coli after ferrate disinfection } \\
\hline WS: & \multicolumn{8}{|c|}{$\begin{array}{l}\text { E.coli grown in 5:1 IO:NB for } 4 \text { days,spun, washed } \mathrm{X} 3 \text { and resuspended in 5:1 } \\
\mathrm{IO} / \mathrm{diH} 2 \mathrm{O}\end{array}$} \\
\hline Conc.(mg/l) & $\begin{array}{l}\text { time } \\
(\min )\end{array}$ & dilution & $\begin{array}{l}\lg \text { wls } \\
\text { pos }\end{array}$ & $\begin{array}{l}\text { sm wls } \\
\text { pos }\end{array}$ & $\begin{array}{l}\text { MPN/ } \\
100 \mathrm{ml}\end{array}$ & $\mathrm{MPN} / \mathrm{ml}$ & $\begin{array}{l}\text { calc } \\
\text { MPN/ml }\end{array}$ & $\begin{array}{l}\text { log } \\
\text { redctn. }\end{array}$ \\
\hline 0 & $15 \mathrm{~min}$ & 3 & 49 & 48 & nd & nd & nd & nd \\
\hline 0 & $15 \mathrm{~min}$ & 7 & 3 & 0 & 3.1 & 310000 & 310000 & $\mathrm{~N} / \mathrm{A}$ \\
\hline 0 & $15 \mathrm{~min}$ & 5 & 48 & 15 & 218.7 & 218700 & 218700 & $\mathrm{~N} / \mathrm{A}$ \\
\hline 5 & $15 \mathrm{~min}$ & 1 & 45 & 7 & 123.6 & 12.36 & 12.36 & 4.25 \\
\hline 5 & $15 \mathrm{~min}$ & 3 & 0 & 0 & 0 & 0 & 10 & 4.34 \\
\hline 10 & $15 \min$ & 1 & 0 & 0 & 0 & 0 & 0.1 & 6.34 \\
\hline 0 & $48 \mathrm{hr}$ & 4 & 49 & 39 & 1046.2 & 104620 & 104620 & 0.32 \\
\hline 0 & $48 \mathrm{hr}$ & 7 & 1 & 0 & 1 & 100000 & 100000 & 0.34 \\
\hline $0+$ glu & $48 \mathrm{hr}$ & 5 & 48 & 28 & 396.8 & 396800 & 396800 & -0.26 \\
\hline $0+$ glu & $48 \mathrm{hr}$ & 8 & 0 & 0 & 0 & 0 & 1000000 & -0.66 \\
\hline 5 & $48 \mathrm{hr}$ & 1 & 11 & 1 & 13.4 & 1.34 & 1.34 & 5.21 \\
\hline 5 & $48 \mathrm{hr}$ & 3 & 0 & 0 & 0 & 0 & 10 & 4.34 \\
\hline $5+$ glu & $48 \mathrm{hr}$ & 1 & 33 & 4 & 58.3 & 5.83 & 5.83 & 4.57 \\
\hline $5+$ glu & $48 \mathrm{hr}$ & 3 & 0 & 1 & 1 & 10 & 10 & 4.34 \\
\hline 10 & $48 \mathrm{hr}$ & 1 & 0 & 0 & 0 & 0 & 0.1 & 6.34 \\
\hline $10+$ glu & $48 \mathrm{hr}$ & 1 & 0 & 0 & 0 & 0 & 0.1 & 6.34 \\
\hline
\end{tabular}


E.8 Experiments on Effect of Salinity

\begin{tabular}{|c|c|c|c|c|c|c|c|c|c|}
\hline $\begin{array}{l}\text { Date of } \\
\text { Expt: }\end{array}$ & \multicolumn{9}{|c|}{$8 / 25 / 2005$} \\
\hline Expt \#: & \multicolumn{9}{|c|}{ 84, Effect of Salinity } \\
\hline Date read: & \multicolumn{9}{|c|}{$8 / 26 / 2005$} \\
\hline WS: & \multicolumn{9}{|c|}{ E.coli grown in 5:1 IO:NB for 2 days,spun, washed $X 3, \&$ resuspended in $5: 1 \mathrm{IO} / \mathrm{diH} 2 \mathrm{O}$} \\
\hline Condition: & \multicolumn{9}{|c|}{$36 \mathrm{ppt}$} \\
\hline Conc. (mg/l) & $\begin{array}{l}\text { time } \\
\text { (min) }\end{array}$ & dilution & $\begin{array}{l}\text { lg wls } \\
\text { pos }\end{array}$ & $\begin{array}{l}\text { sm wls } \\
\text { pos }\end{array}$ & $\begin{array}{l}\text { MPN/ } \\
100 \mathrm{ml}\end{array}$ & $\mathrm{MPN} / \mathrm{ml}$ & $\begin{array}{l}\text { calc } \\
\text { MPN/ml }\end{array}$ & $\begin{array}{l}\text { log } \\
\text { redctn. }\end{array}$ & $\begin{array}{l}\text { delta } \\
\text { log } \\
\text { redctn. }\end{array}$ \\
\hline 0 & 0 & 3 & 49 & 48 & $>2419.6$ & $>24.2$ & $>24.2$ & $\mathrm{~N} / \mathrm{A}$ & \\
\hline 0 & 0 & 5 & 49 & 48 & $>2419.6$ & $>24.2$ & $>24.2$ & $\mathrm{~N} / \mathrm{A}$ & \\
\hline 0 & 0 & 7 & 39 & 6 & 83.6 & 8360000 & 8360000 & $\mathrm{~N} / \mathrm{A}$ & \\
\hline 0 & 2 & 5 & 49 & 48 & $>2419.6$ & $>24.2$ & $>24.2$ & $\mathrm{~N} / \mathrm{A}$ & \\
\hline 0 & 2 & 7 & 40 & 4 & 83.3 & 8330000 & 8330000 & 0.00 & \\
\hline 0 & 5 & 5 & 49 & 48 & $>2419.6$ & $>24.2$ & $>24.2$ & $\mathrm{~N} / \mathrm{A}$ & \\
\hline 0 & 5 & 7 & 40 & 5 & 85.7 & 8570000 & 8570000 & -0.01 & \\
\hline 0 & 15 & 5 & 49 & 48 & $>2419.6$ & $>24.2$ & $>24.2$ & $\mathrm{~N} / \mathrm{A}$ & \\
\hline 0 & 15 & 7 & 39 & 6 & 83.6 & 8360000 & 8360000 & 0.00 & \\
\hline 0 & 30 & 5 & 49 & 48 & $>2419.6$ & $>24.2$ & $>24.2$ & $\mathrm{~N} / \mathrm{A}$ & \\
\hline 0 & 30 & 7 & 38 & 5 & 77.1 & 7710000 & 7710000 & 0.04 & \\
\hline 0.25 & 2 & 3 & 49 & 48 & $>2419.6$ & $>24.2$ & $>24.2$ & $\mathrm{~N} / \mathrm{A}$ & \\
\hline 0.25 & 2 & 6 & 44 & 25 & 193.6 & 1936000 & 1936000 & 0.64 & 0.63 \\
\hline 0.25 & 5 & 3 & 49 & 48 & $>2419.6$ & $>24.2$ & $>24.2$ & $\mathrm{~N} / \mathrm{A}$ & N/A \\
\hline 0.25 & 5 & 6 & 32 & 22 & 89.5 & 895000 & 895000 & 0.97 & 0.98 \\
\hline 0.25 & 15 & 3 & 49 & 48 & $>2419.6$ & $>24.2$ & $>24.2$ & N/A & N/A \\
\hline 0.25 & 15 & 6 & 31 & 14 & 70.5 & 705000 & 705000 & 1.07 & 1.07 \\
\hline 0.25 & 30 & 3 & 49 & 48 & $>2419.6$ & $>24.2$ & $>24.2$ & $\mathrm{~N} / \mathrm{A}$ & N/A \\
\hline 0.25 & 30 & 5 & 47 & 24 & 270 & 270000 & 270000 & 1.49 & 1.46 \\
\hline 0.75 & 2 & 2 & 49 & 48 & $>2419.6$ & $>24.2$ & $>24.2$ & $\mathrm{~N} / \mathrm{A}$ & N/A \\
\hline 0.75 & 2 & 4 & 47 & 28 & 316.9 & 31690 & 31690 & 2.42 & 2.42 \\
\hline 0.75 & 5 & 2 & 49 & 48 & $>2419.6$ & $>24.2$ & $>24.2$ & N/A & $\mathrm{N} / \mathrm{A}$ \\
\hline 0.75 & 5 & 4 & 31 & 5 & 54.6 & 5460 & 5460 & 3.19 & 3.20 \\
\hline 0.75 & 15 & 2 & 49 & 48 & $>2419.6$ & $>24.2$ & $>24.2$ & N/A & N/A \\
\hline 0.75 & 15 & 4 & 19 & 2 & 25.9 & 2590 & 2590 & 3.51 & 3.51 \\
\hline 0.75 & 30 & 2 & 49 & 48 & $>2419.6$ & $>24.2$ & $>24.2$ & N/A & N/A \\
\hline 0.75 & 30 & 4 & 17 & 2 & 22.8 & 2280 & 2280 & 3.56 & 3.53 \\
\hline 1.5 & 2 & 2 & 49 & 48 & $>2419.6$ & $>24.2$ & $>24.2$ & $\mathrm{~N} / \mathrm{A}$ & N/A \\
\hline 1.5 & 2 & 4 & 38 & 16 & 103.4 & 10340 & 10340 & 2.91 & 2.91 \\
\hline 1.5 & 5 & 2 & 49 & 44 & 1413.6 & 1413.6 & 1413.6 & 3.77 & 3.78 \\
\hline 1.5 & 5 & 4 & 10 & 1 & 12.1 & 1210 & 1210 & 3.84 & 3.85 \\
\hline 1.5 & 15 & 1 & 49 & 48 & $>2419.6$ & $>24.2$ & $>24.2$ & $\mathrm{~N} / \mathrm{A}$ & $\mathrm{N} / \mathrm{A}$ \\
\hline 1.5 & 15 & 3 & 29 & 8 & 54.5 & 545 & 545 & 4.19 & 4.19 \\
\hline 1.5 & 30 & 1 & 49 & 48 & $>2419.6$ & $>24.2$ & $>24.2$ & $\mathrm{~N} / \mathrm{A}$ & N/A \\
\hline 1.5 & 30 & 4 & 3 & 0 & 3.1 & 310 & 310 & 4.43 & 4.40 \\
\hline 3 & 2 & 1 & 49 & 44 & 1553.1 & 155.31 & 155.31 & 4.73 & 4.73 \\
\hline 3 & 5 & 1 & 49 & 31 & 648.8 & 64.88 & 64.88 & 5.11 & 5.12 \\
\hline 3 & 15 & 1 & 46 & 25 & 241.5 & 24.15 & 24.15 & 5.54 & 5.54 \\
\hline 3 & 30 & 1 & 16 & 2 & 21.3 & 2.13 & 2.13 & 6.59 & 6.56 \\
\hline 5 & 2 & 1 & 22 & 0 & 28.2 & 2.82 & 2.82 & 6.47 & 6.47 \\
\hline 5 & 5 & 1 & 10 & 0 & 11 & 1.1 & 1.1 & 6.88 & 6.89 \\
\hline 5 & 15 & 1 & 0 & 0 & 0 & 0 & 0.1 & 7.92 & 7.92 \\
\hline 5 & 30 & 1 & 0 & 0 & 0 & 0 & 0.1 & 7.92 & 7.89 \\
\hline
\end{tabular}




\begin{tabular}{|c|c|c|c|c|c|c|c|c|c|}
\hline Expt \#: & 84 & & & & & & & & \\
\hline Condition: & $10 \mathrm{ppt}$ & & & & & & & & \\
\hline & time & & lg wls & sm wls & MPN/ & & calc & & $\log$ \\
\hline Conc.(mg/l) & $(\min )$ & dilution & pos & pos & $100 \mathrm{ml}$ & MPN/ml & $\mathrm{MPN} / \mathrm{ml}$ & redctn. & \\
\hline 0 & 0 & 3 & 49 & 48 & $>2419.6$ & $>24.2$ & $>24.2$ & N/A & \\
\hline 0 & 0 & 5 & 49 & 48 & $>2419.6$ & $>24.2$ & $>24.2$ & $\mathrm{~N} / \mathrm{A}$ & \\
\hline 0 & 0 & 7 & 43 & 11 & 121.1 & 12110000 & 12110000 & $\mathrm{~N} / \mathrm{A}$ & \\
\hline 0 & 2 & 5 & 49 & 48 & $>2419.6$ & $>24.2$ & $>24.2$ & $\mathrm{~N} / \mathrm{A}$ & \\
\hline 0 & 2 & 7 & 44 & 9 & 122.3 & 12230000 & 12230000 & 0.00 & \\
\hline 0 & 5 & 5 & 49 & 48 & $>2419.6$ & $>24.2$ & $>24.2$ & $\mathrm{~N} / \mathrm{A}$ & \\
\hline 0 & 5 & 7 & 44 & 11 & 129.6 & 12960000 & 12960000 & -0.19 & \\
\hline 0 & 15 & 5 & 49 & 48 & $>2419.6$ & $>24.2$ & $>24.2$ & $\mathrm{~N} / \mathrm{A}$ & \\
\hline 0 & 15 & 7 & 42 & 12 & 116.9 & 11690000 & 11690000 & -0.15 & \\
\hline 0 & 30 & 5 & 49 & 48 & $>2419.6$ & $>24.2$ & $>24.2$ & $\mathrm{~N} / \mathrm{A}$ & \\
\hline 0 & 30 & 7 & 42 & 13 & 120.1 & 12010000 & 12010000 & -0.16 & \\
\hline 0.25 & 2 & 3 & 49 & 48 & $>2419.6$ & $>24.2$ & $>24.2$ & N/A & \\
\hline 0.25 & 2 & 6 & 46 & 25 & 241.5 & 2415000 & 2415000 & 0.70 & 0.70 \\
\hline 0.25 & 5 & 3 & 49 & 48 & $>2419.6$ & $>24.2$ & $>24.2$ & N/A & $\mathrm{N} / \mathrm{A}$ \\
\hline 0.25 & 5 & 6 & 39 & 27 & 141.7 & 1417000 & 1417000 & 0.93 & 1.12 \\
\hline 0.25 & 15 & 3 & 49 & 48 & $>2419.6$ & $>24.2$ & $>24.2$ & N/A & $\mathrm{N} / \mathrm{A}$ \\
\hline 0.25 & 15 & 6 & 37 & 9 & 82 & 820000 & 820000 & 1.17 & 1.31 \\
\hline 0.25 & 30 & 3 & 49 & 48 & $>2419.6$ & $>24.2$ & $>24.2$ & N/A & $\mathrm{N} / \mathrm{A}$ \\
\hline 0.25 & 30 & 5 & 48 & 33 & 501.2 & 501200 & 501200 & 1.38 & 1.54 \\
\hline 0.75 & 2 & 2 & 49 & 48 & $>2419.6$ & $>24.2$ & $>24.2$ & N/A & $\mathrm{N} / \mathrm{A}$ \\
\hline 0.75 & 2 & 4 & 48 & 43 & 791.5 & 79150 & 79150 & 2.18 & 2.19 \\
\hline 0.75 & 5 & 2 & 49 & 48 & $>2419.6$ & $>24.2$ & $>24.2$ & N/A & $\mathrm{N} / \mathrm{A}$ \\
\hline 0.75 & 5 & 4 & 45 & 34 & 284.1 & 28410 & 28410 & 2.63 & 2.82 \\
\hline 0.75 & 15 & 2 & 49 & 48 & $>2419.6$ & $>24.2$ & $>24.2$ & N/A & $\mathrm{N} / \mathrm{A}$ \\
\hline 0.75 & 15 & 4 & 29 & 2 & 44.8 & 4480 & 4480 & 3.43 & 3.58 \\
\hline 0.75 & 30 & 2 & 49 & 48 & $>2419.6$ & $>24.2$ & $>24.2$ & N/A & $\mathrm{N} / \mathrm{A}$ \\
\hline 0.75 & 30 & 4 & 21 & 1 & 27.9 & 2790 & 2790 & 3.64 & 3.79 \\
\hline 1.5 & 2 & 2 & 49 & 48 & $>2419.6$ & $>24.2$ & $>24.2$ & N/A & $N / A$ \\
\hline 1.5 & 2 & 4 & 40 & 17 & 62.7 & 6270 & 6270 & 3.29 & 3.29 \\
\hline 1.5 & 5 & 2 & 49 & 45 & 1732.9 & 1732.9 & 1732.9 & 3.84 & 4.03 \\
\hline 1.5 & 5 & 4 & 19 & 0 & 23.3 & 2330 & 2330 & 3.72 & 3.91 \\
\hline 1.5 & 15 & 1 & 49 & 48 & $>2419.6$ & $>24.2$ & $>24.2$ & $\mathrm{~N} / \mathrm{A}$ & $\mathrm{N} / \mathrm{A}$ \\
\hline 1.5 & 15 & 3 & 24 & 2 & 34.5 & 345 & 345 & 4.55 & 4.69 \\
\hline 1.5 & 30 & 1 & 49 & 48 & $>2419.6$ & $>24.2$ & $>24.2$ & N/A & $\mathrm{N} / \mathrm{A}$ \\
\hline 1.5 & 30 & 3 & 19 & 1 & 24.6 & 246 & 246 & 4.69 & 4.85 \\
\hline 3 & 2 & 1 & 49 & 39 & 1046.2 & 104.62 & 104.62 & 5.06 & 5.07 \\
\hline 3 & 5 & 1 & 42 & 14 & 123.4 & 12.34 & 12.34 & 5.99 & 6.18 \\
\hline 3 & 15 & 1 & 25 & 4 & 39.3 & 3.93 & 3.93 & 6.49 & 6.63 \\
\hline 3 & 30 & 1 & 8 & 0 & 8.6 & 0.86 & 0.86 & 7.15 & 7.31 \\
\hline 5 & 2 & 1 & 29 & 5 & 49.6 & 4.96 & 4.96 & 6.39 & 6.39 \\
\hline 5 & 5 & 1 & 15 & 2 & 19.9 & 1.99 & 1.99 & 6.78 & 6.97 \\
\hline 5 & 15 & 1 & 0 & 0 & 0 & 0 & 0.1 & 8.08 & 8.23 \\
\hline 5 & 30 & 1 & 0 & 0 & 0 & 0 & 0.1 & 8.08 & 8.24 \\
\hline
\end{tabular}




\begin{tabular}{|c|c|c|c|c|c|c|c|c|c|}
\hline $\begin{array}{l}\text { Date of } \\
\text { Expt: }\end{array}$ & \multicolumn{9}{|c|}{$8 / 25 / 2005$} \\
\hline Expt \#: & \multicolumn{9}{|c|}{85 , Effect of salinity } \\
\hline Date read: & \multicolumn{9}{|c|}{$8 / 26 / 2005$} \\
\hline WS: & \multicolumn{9}{|c|}{ E.coli grown in 5:1 IO:NB for 5 days,spun, washed X3, \& resuspended in $5: 1 \mathrm{IO} / \mathrm{diH} 2 \mathrm{O}$} \\
\hline Condition: & \multicolumn{9}{|c|}{$36 \mathrm{ppt}$} \\
\hline Conc. $(\mathrm{mg} / \mathrm{l})$ & $\begin{array}{l}\text { time } \\
(\min )\end{array}$ & dilution & $\begin{array}{l}\text { lg wls } \\
\text { pos }\end{array}$ & $\begin{array}{l}\text { sm wls } \\
\text { pos }\end{array}$ & $\begin{array}{l}\text { MPN/ } \\
100 \mathrm{ml}\end{array}$ & $\mathrm{MPN} / \mathrm{ml}$ & $\begin{array}{l}\text { calc } \\
\text { MPN/ml }\end{array}$ & $\begin{array}{l}\text { log } \\
\text { redctn. }\end{array}$ & $\begin{array}{l}\text { delta } \\
\text { log } \\
\text { redctn. }\end{array}$ \\
\hline 0 & 0 & 3 & 49 & 48 & $>2419.6$ & $>24.2$ & $>24.2$ & $\mathrm{~N} / \mathrm{A}$ & \\
\hline 0 & 0 & 6 & 49 & 34 & 770.1 & 7701000 & 7701000 & $\mathrm{~N} / \mathrm{A}$ & \\
\hline 0 & 2 & 5 & 49 & 48 & $>2419.6$ & $>24.2$ & $>24.2$ & $\mathrm{~N} / \mathrm{A}$ & \\
\hline 0 & 2 & 7 & 38 & 4 & 74.9 & 7490000 & 7490000 & 0.01 & \\
\hline 0 & 5 & 5 & 49 & 48 & $>2419.6$ & $>24.2$ & $>24.2$ & N/A & \\
\hline 0 & 5 & 7 & 40 & 3 & 80.9 & 8090000 & 8090000 & -0.02 & \\
\hline 0 & 15 & 5 & 49 & 48 & $>2419.6$ & $>24.2$ & $>24.2$ & $\mathrm{~N} / \mathrm{A}$ & \\
\hline 0 & 15 & 7 & 38 & 6 & 79.4 & 7940000 & 7940000 & -0.01 & \\
\hline 0 & 30 & 5 & 49 & 48 & $>2419.6$ & $>24.2$ & $>24.2$ & N/A & \\
\hline 0 & 30 & 7 & 37 & 5 & 73.3 & 7330000 & 7330000 & 0.02 & \\
\hline 0.25 & 2 & 3 & 49 & 48 & $>2419.6$ & $>24.2$ & $>24.2$ & $\mathrm{~N} / \mathrm{A}$ & \\
\hline 0.25 & 2 & 6 & 43 & 14 & 131.7 & 1317000 & 1317000 & 0.77 & 0.75 \\
\hline 0.25 & 5 & 3 & 49 & 48 & $>2419.6$ & $>24.2$ & $>24.2$ & $\mathrm{~N} / \mathrm{A}$ & $\mathrm{N} / \mathrm{A}$ \\
\hline 0.25 & 5 & 6 & 26 & 4 & 41.4 & 414000 & 414000 & 1.27 & 1.29 \\
\hline 0.25 & 15 & 3 & 49 & 48 & $>2419.6$ & $>24.2$ & $>24.2$ & $\mathrm{~N} / \mathrm{A}$ & $\mathrm{N} / \mathrm{A}$ \\
\hline 0.25 & 15 & 6 & 18 & 0 & 21.8 & 218000 & 218000 & 1.55 & 1.56 \\
\hline 0.25 & 30 & 3 & 49 & 48 & $>2419.6$ & $>24.2$ & $>24.2$ & $\mathrm{~N} / \mathrm{A}$ & $\mathrm{N} / \mathrm{A}$ \\
\hline 0.25 & 30 & 5 & 47 & 16 & 198.9 & 198900 & 198900 & 1.59 & 1.57 \\
\hline 0.75 & 2 & 2 & 49 & 48 & $>2419.6$ & $>24.2$ & $>24.2$ & $\mathrm{~N} / \mathrm{A}$ & $\mathrm{N} / \mathrm{A}$ \\
\hline 0.75 & 2 & 4 & 46 & 36 & 355.5 & 35550 & 35550 & 2.34 & 2.32 \\
\hline 0.75 & 5 & 2 & 49 & 48 & $>2419.6$ & $>24.2$ & $>24.2$ & $\mathrm{~N} / \mathrm{A}$ & $\mathrm{N} / \mathrm{A}$ \\
\hline 0.75 & 5 & 4 & 37 & 9 & 82 & 8200 & 8200 & 2.97 & 2.99 \\
\hline 0.75 & 15 & 2 & 49 & 48 & $>2419.6$ & $>24.2$ & $>24.2$ & $\mathrm{~N} / \mathrm{A}$ & $\mathrm{N} / \mathrm{A}$ \\
\hline 0.75 & 15 & 4 & 20 & 1 & 26.2 & 2620 & 2620 & 3.47 & 3.48 \\
\hline 0.75 & 30 & 1 & 49 & 48 & $>2419.6$ & $>24.2$ & $>24.2$ & $\mathrm{~N} / \mathrm{A}$ & $\mathrm{N} / \mathrm{A}$ \\
\hline 0.75 & 30 & 3 & 46 & 18 & 190.4 & 1904 & 1904 & 3.61 & 3.59 \\
\hline 1.5 & 2 & 2 & 48 & 46 & 870.4 & 870.4 & 870.4 & 3.95 & 3.93 \\
\hline 1.5 & 2 & 4 & 9 & 4 & 14.2 & 1420 & 1420 & 3.73 & 3.72 \\
\hline 1.5 & 5 & 2 & 49 & 35 & 816.4 & 816.4 & 816.4 & 3.97 & 4.00 \\
\hline 1.5 & 5 & 4 & 5 & 1 & 6.3 & 630 & 630 & 4.09 & 4.11 \\
\hline 1.5 & 15 & 1 & 47 & 13 & 178.5 & 17.85 & 17.85 & 5.63 & 5.65 \\
\hline 1.5 & 15 & 3 & 3 & 0 & 3.1 & 31 & 31 & 5.40 & 5.41 \\
\hline 1.5 & 30 & 1 & 44 & 6 & 111.9 & 11.19 & 11.19 & 5.84 & 5.82 \\
\hline 1.5 & 30 & 3 & 2 & 0 & 2 & 20 & 20 & 5.59 & 5.56 \\
\hline 3 & 2 & 1 & 49 & 46 & 1986.3 & 198.63 & 198.63 & 4.59 & 4.58 \\
\hline 3 & 2 & 3 & 13 & 1 & 16 & 160 & 160 & 4.68 & 4.67 \\
\hline 3 & 5 & 1 & 46 & 22 & 217.8 & 21.78 & 21.78 & 5.55 & 5.57 \\
\hline 3 & 15 & 1 & 35 & 4 & 64.4 & 6.44 & 6.44 & 6.08 & 6.09 \\
\hline 3 & 30 & 1 & 12 & 1 & 14.6 & 1.46 & 1.46 & 6.72 & 6.70 \\
\hline 5 & 2 & 1 & 4 & 1 & 5.2 & 0.52 & 0.52 & 7.17 & 7.16 \\
\hline 5 & 5 & 1 & 2 & 0 & 2 & 0.2 & 0.2 & 7.59 & 7.61 \\
\hline 5 & 15 & 1 & 1 & 0 & 1 & 0.1 & 0.1 & 7.89 & 7.90 \\
\hline 5 & 30 & 1 & 0 & 0 & 0 & 0 & 0.1 & 7.89 & 7.87 \\
\hline
\end{tabular}




\begin{tabular}{|c|c|c|c|c|c|c|c|c|c|}
\hline Expt \#: & 85 & & & & & & & & \\
\hline Condition: & $10 \mathrm{ppt}$ & & & & & & & & delta \\
\hline Conc.(mg/l) & $\begin{array}{l}\text { time } \\
\text { (min) }\end{array}$ & dilution & $\begin{array}{l}\text { lg wls } \\
\text { pos }\end{array}$ & $\begin{array}{l}\text { sm wls } \\
\text { pos }\end{array}$ & $\begin{array}{l}\text { MPN/ } \\
100 \mathrm{ml}\end{array}$ & $\mathrm{MPN} / \mathrm{ml}$ & $\begin{array}{l}\text { calc } \\
\text { MPN/ml }\end{array}$ & $\begin{array}{l}\text { log } \\
\text { redctn. }\end{array}$ & $\begin{array}{l}\text { log } \\
\text { redctn. }\end{array}$ \\
\hline 0 & 0 & 3 & 49 & 48 & $>2419.6$ & $>24.2$ & $>24.2$ & $\mathrm{~N} / \mathrm{A}$ & \\
\hline 0 & 0 & 5 & nd & nd & nd & nd & nd & nd & \\
\hline 0 & 0 & 6 & 49 & 37 & 920.8 & 9208000 & 9208000 & $\mathrm{~N} / \mathrm{A}$ & \\
\hline 0 & 2 & 5 & 49 & 48 & $>2419.6$ & $>24.2$ & $>24.2$ & $\mathrm{~N} / \mathrm{A}$ & \\
\hline 0 & 2 & 7 & 44 & 9 & 122.3 & 12230000 & 12230000 & -0.12 & \\
\hline 0 & 5 & 5 & 49 & 48 & $>2419.6$ & $>24.2$ & $>24.2$ & N/A & \\
\hline 0 & 5 & 7 & 44 & 11 & 129.6 & 12960000 & 12960000 & -0.23 & \\
\hline 0 & 15 & 5 & 49 & 48 & $>2419.6$ & $>24.2$ & $>24.2$ & N/A & \\
\hline 0 & 15 & 7 & 42 & 12 & 116.9 & 11690000 & 11690000 & -0.18 & \\
\hline 0 & 30 & 5 & 49 & 48 & $>2419.6$ & $>24.2$ & $>24.2$ & N/A & \\
\hline 0 & 30 & 7 & 42 & 13 & 120.1 & 12010000 & 12010000 & -0.19 & \\
\hline 0.25 & 2 & 3 & 49 & 48 & $>2419.6$ & $>24.2$ & $>24.2$ & N/A & \\
\hline 0.25 & 2 & 6 & 42 & 12 & 120.1 & 1201000 & 1201000 & 0.88 & 1.01 \\
\hline 0.25 & 5 & 3 & 49 & 48 & $>2419.6$ & $>24.2$ & $>24.2$ & $\mathrm{~N} / \mathrm{A}$ & $\mathrm{N} / \mathrm{A}$ \\
\hline 0.25 & 5 & 6 & 26 & 1 & 36.9 & 369000 & 369000 & 1.40 & 1.62 \\
\hline 0.25 & 15 & 3 & 49 & 48 & $>2419.6$ & $>24.2$ & $>24.2$ & $\mathrm{~N} / \mathrm{A}$ & $\mathrm{N} / \mathrm{A}$ \\
\hline 0.25 & 15 & 6 & 22 & 1 & 29.5 & 295000 & 295000 & 1.49 & 1.68 \\
\hline 0.25 & 30 & 3 & 49 & 48 & $>2419.6$ & $>24.2$ & $>24.2$ & $\mathrm{~N} / \mathrm{A}$ & $\mathrm{N} / \mathrm{A}$ \\
\hline 0.25 & 30 & 5 & 44 & 28 & 211 & 211000 & 211000 & 1.64 & 1.83 \\
\hline 0.75 & 2 & 2 & 49 & 48 & $>2419.6$ & $>24.2$ & $>24.2$ & $\mathrm{~N} / \mathrm{A}$ & $\mathrm{N} / \mathrm{A}$ \\
\hline 0.75 & 2 & 4 & 47 & 43 & 550.4 & 55040 & 55040 & 2.22 & 2.35 \\
\hline 0.75 & 5 & 2 & 49 & 48 & $>2419.6$ & $>24.2$ & $>24.2$ & $\mathrm{~N} / \mathrm{A}$ & $\mathrm{N} / \mathrm{A}$ \\
\hline 0.75 & 5 & 4 & 45 & 20 & 183.5 & 18350 & 18350 & 2.70 & 2.93 \\
\hline 0.75 & 15 & 2 & 49 & 48 & $>2419.6$ & $>24.2$ & $>24.2$ & $\mathrm{~N} / \mathrm{A}$ & $\mathrm{N} / \mathrm{A}$ \\
\hline 0.75 & 15 & 4 & 23 & 2 & 32.4 & 3240 & 3240 & 3.45 & 3.63 \\
\hline 0.75 & 30 & 2 & 49 & 48 & $>2419.6$ & $>24.2$ & $>24.2$ & $\mathrm{~N} / \mathrm{A}$ & $\mathrm{N} / \mathrm{A}$ \\
\hline 0.75 & 30 & 4 & 21 & 1 & 27.9 & 2790 & 2790 & 3.52 & 3.71 \\
\hline 1.5 & 2 & 2 & 49 & 48 & $>2419.6$ & $>24.2$ & $>24.2$ & $\mathrm{~N} / \mathrm{A}$ & $\mathrm{N} / \mathrm{A}$ \\
\hline 1.5 & 2 & 4 & 40 & 17 & 62.7 & 6270 & 6270 & 3.17 & 3.29 \\
\hline 1.5 & 5 & 2 & 49 & 45 & 1732.9 & 1732.9 & 1732.9 & 3.73 & 3.95 \\
\hline 1.5 & 5 & 4 & 14 & 0 & 16.1 & 1610 & 1610 & 3.76 & 3.98 \\
\hline 1.5 & 15 & 1 & 49 & 48 & $>2419.6$ & $>24.2$ & $>24.2$ & $\mathrm{~N} / \mathrm{A}$ & $\mathrm{N} / \mathrm{A}$ \\
\hline 1.5 & 15 & 3 & 21 & 1 & 27.9 & 279 & 279 & 4.52 & 4.70 \\
\hline 1.5 & 30 & 1 & 49 & 48 & $>2419.6$ & $>24.2$ & $>24.2$ & $\mathrm{~N} / \mathrm{A}$ & $\mathrm{N} / \mathrm{A}$ \\
\hline 1.5 & 30 & 3 & 9 & 0 & 9.8 & 98 & 98 & 4.97 & 5.17 \\
\hline 3 & 2 & 1 & 49 & 43 & 1413.6 & 141.36 & 141.36 & 4.81 & 4.94 \\
\hline 3 & 5 & 1 & 44 & 16 & 149.7 & 14.97 & 14.97 & 5.79 & 6.02 \\
\hline 3 & 15 & 1 & 36 & 4 & 67.7 & 6.77 & 6.77 & 6.13 & 6.31 \\
\hline 3 & 30 & 1 & 12 & 3 & 16.9 & 1.69 & 1.69 & 6.74 & 6.93 \\
\hline 5 & 2 & 1 & 25 & 2 & 36.4 & 3.64 & 3.64 & 6.40 & 6.53 \\
\hline 5 & 5 & 1 & 7 & 0 & 7.5 & 0.75 & 0.75 & 7.09 & 7.32 \\
\hline 5 & 15 & 1 & 3 & 0 & 3.1 & 0.31 & 0.31 & 7.47 & 7.65 \\
\hline 5 & 30 & 1 & 0 & 0 & 0 & 0 & 0.1 & 7.96 & 8.16 \\
\hline
\end{tabular}




\section{E.9 Experiments on Effect of $\mathrm{pH}$}

\begin{tabular}{|c|c|c|c|c|c|c|c|c|c|}
\hline $\begin{array}{l}\text { Date of } \\
\text { Expt: }\end{array}$ & \multicolumn{9}{|l|}{$8 / 9 / 2005$} \\
\hline Expt \#: & \multicolumn{9}{|c|}{77} \\
\hline Date read: & \multicolumn{9}{|c|}{$8 / 10 / 2005$} \\
\hline Purpose: & \multicolumn{9}{|c|}{ Effect of $\mathrm{pH}$} \\
\hline WS: & \multicolumn{9}{|c|}{ E.coli grown in 5:1 IO:NB for 4 days,spun, washed $\mathrm{X} 3, \&$ resuspended in $5: 1 \mathrm{IO} / \mathrm{diH} 2 \mathrm{O}$} \\
\hline Condition: & \multicolumn{9}{|c|}{$\mathrm{N}($ Normal pH) } \\
\hline Conc.(mg/l) & $\begin{array}{l}\text { time } \\
\text { (min) }\end{array}$ & dilution & $\begin{array}{l}\text { lg wls } \\
\text { pos }\end{array}$ & $\begin{array}{l}\text { sm wls } \\
\text { pos }\end{array}$ & $\begin{array}{l}\text { MPN/ } \\
100 \mathrm{ml}\end{array}$ & $\mathrm{MPN} / \mathrm{ml}$ & $\begin{array}{l}\text { calc } \\
\text { MPN/ml }\end{array}$ & $\begin{array}{l}\text { log } \\
\text { redctn. }\end{array}$ & $\begin{array}{l}\text { delta } \\
\text { log } \\
\text { redctn. }\end{array}$ \\
\hline 0 & 0 & 3 & 49 & 48 & $>2419.6$ & $>24.2$ & $>24.2$ & N/A & \\
\hline 0 & 0 & 5 & 49 & 48 & $>2419.6$ & $>24.2$ & $>24.2$ & $\mathrm{~N} / \mathrm{A}$ & \\
\hline 0 & 0 & 7 & 49 & 22 & 387.3 & 38730000 & 38730000 & $\mathrm{~N} / \mathrm{A}$ & \\
\hline 0 & 2 & 5 & 49 & 48 & $>2419.6$ & $>24.2$ & $>24.2$ & $\mathrm{~N} / \mathrm{A}$ & \\
\hline 0 & 2 & 7 & 49 & 25 & 461.1 & 46110000 & 46110000 & -0.08 & \\
\hline 0 & 5 & 5 & 49 & 48 & $>2419.6$ & $>24.2$ & $>24.2$ & $\mathrm{~N} / \mathrm{A}$ & \\
\hline 0 & 5 & 7 & 49 & 21 & 365.4 & 36540000 & 36540000 & 0.03 & \\
\hline 0 & 15 & 5 & 49 & 48 & $>2419.6$ & $>24.2$ & $>24.2$ & $\mathrm{~N} / \mathrm{A}$ & \\
\hline 0 & 15 & 7 & 49 & 24 & 435.2 & 43520000 & 43520000 & -0.05 & \\
\hline 0 & 30 & 5 & 49 & 48 & $>2419.6$ & $>24.2$ & $>24.2$ & $\mathrm{~N} / \mathrm{A}$ & \\
\hline 0 & 30 & 7 & 48 & 24 & 328.2 & 32820000 & 32820000 & 0.07 & \\
\hline 0.75 & 2 & 3 & 49 & 48 & $>2419.6$ & $>24.2$ & $>24.2$ & $\mathrm{~N} / \mathrm{A}$ & \\
\hline 0.75 & 2 & 5 & 49 & 36 & 866.4 & 866400 & 866400 & 1.65 & 1.73 \\
\hline 0.75 & 5 & 3 & 49 & 48 & $>2419.6$ & $>24.2$ & $>24.2$ & $\mathrm{~N} / \mathrm{A}$ & $\mathrm{N} / \mathrm{A}$ \\
\hline 0.75 & 5 & 5 & 45 & 15 & 157.6 & 157600 & 157600 & 2.39 & 2.37 \\
\hline 0.75 & 15 & 2 & 49 & 48 & $>2419.6$ & $>24.2$ & $>24.2$ & $\mathrm{~N} / \mathrm{A}$ & $\mathrm{N} / \mathrm{A}$ \\
\hline 0.75 & 15 & 5 & 41 & 6 & 93.3 & 93300 & 93300 & 2.62 & 2.67 \\
\hline 0.75 & 30 & 2 & 49 & 48 & $>2419.6$ & $>24.2$ & $>24.2$ & N/A & N/A \\
\hline 0.75 & 30 & 5 & 24 & 0 & 31.7 & 31700 & 31700 & 3.09 & 3.02 \\
\hline 1.5 & 2 & 1 & 49 & 48 & $>2419.6$ & $>24.2$ & $>24.2$ & $\mathrm{~N} / \mathrm{A}$ & $\mathrm{N} / \mathrm{A}$ \\
\hline 1.5 & 2 & 4 & 49 & 29 & 579.4 & 57940 & 57940 & 2.83 & 2.90 \\
\hline 1.5 & 5 & 1 & 49 & 48 & $>2419.6$ & $>24.2$ & $>24.2$ & $\mathrm{~N} / \mathrm{A}$ & $\mathrm{N} / \mathrm{A}$ \\
\hline 1.5 & 5 & 3 & 49 & 34 & 770.1 & 7701 & 7701 & 3.70 & 3.68 \\
\hline 1.5 & 15 & 1 & 49 & 48 & $>2419.6$ & $>24.2$ & $>24.2$ & $\mathrm{~N} / \mathrm{A}$ & $\mathrm{N} / \mathrm{A}$ \\
\hline 1.5 & 15 & 3 & 47 & 18 & 214.2 & 2142 & 2142 & 4.26 & 4.31 \\
\hline 1.5 & 30 & 1 & 49 & 48 & $>2419.6$ & $>24.2$ & $>24.2$ & $\mathrm{~N} / \mathrm{A}$ & N/A \\
\hline 1.5 & 30 & 3 & 47 & 12 & 172.3 & 1723 & 1723 & 4.35 & 4.28 \\
\hline
\end{tabular}




\begin{tabular}{|c|c|c|c|c|c|c|c|c|c|}
\hline Expt \#: & 77 & & & & & & & & \\
\hline Condition: & $-\mathrm{pH}$ (Acid & $\mathrm{pH})$ & & & & & & & delta \\
\hline Conc.(mg/l) & $\begin{array}{l}\text { time } \\
(\min )\end{array}$ & dilution & $\begin{array}{l}\text { lg wls } \\
\text { pos }\end{array}$ & $\begin{array}{l}\text { sm wls } \\
\text { pos }\end{array}$ & $\begin{array}{l}\text { MPN/ } \\
100 \mathrm{ml}\end{array}$ & $\mathrm{MPN} / \mathrm{ml}$ & $\begin{array}{l}\text { calc } \\
\text { MPN/ml }\end{array}$ & $\begin{array}{l}\text { log } \\
\text { redctn. }\end{array}$ & $\begin{array}{l}\text { log } \\
\text { redctn. }\end{array}$ \\
\hline 0 & 0 & 3 & 49 & 48 & $>2419.6$ & $>24.2$ & $>24.2$ & $\mathrm{~N} / \mathrm{A}$ & \\
\hline 0 & 0 & 5 & 49 & 48 & $>2419.6$ & $>24.2$ & $>24.2$ & $\mathrm{~N} / \mathrm{A}$ & \\
\hline 0 & 0 & 7 & 49 & 26 & 488.4 & 48840000 & 48840000 & $\mathrm{~N} / \mathrm{A}$ & \\
\hline 0 & 2 & 5 & 49 & 48 & $>2419.6$ & $>24.2$ & $>24.2$ & $\mathrm{~N} / \mathrm{A}$ & \\
\hline 0 & 2 & 7 & 49 & 23 & 410.6 & 41060000 & 41060000 & 0.08 & \\
\hline 0 & 5 & 5 & 49 & 48 & $>2419.6$ & $>24.2$ & $>24.2$ & N/A & \\
\hline 0 & 5 & 7 & 49 & 23 & 410.6 & 41060000 & 41060000 & 0.08 & \\
\hline 0 & 15 & 5 & 49 & 48 & $>2419.6$ & $>24.2$ & $>24.2$ & $\mathrm{~N} / \mathrm{A}$ & \\
\hline 0 & 15 & 7 & 49 & 25 & 461.1 & 46110000 & 46110000 & 0.02 & \\
\hline 0 & 30 & 5 & 49 & 48 & $>2419.6$ & $>24.2$ & $>24.2$ & N/A & \\
\hline 0 & 30 & 7 & 48 & 28 & 396.8 & 39680000 & 39680000 & 0.09 & \\
\hline 0.75 & 2 & 3 & 49 & 47 & 2419.6 & 24196 & 24196 & 3.31 & \\
\hline 0.75 & 2 & 5 & 49 & 20 & 344.8 & 344800 & 344800 & 2.15 & 2.08 \\
\hline 0.75 & 5 & 3 & 49 & 48 & $>2419.6$ & $>24.2$ & $>24.2$ & N/A & $\mathrm{N} / \mathrm{A}$ \\
\hline 0.75 & 5 & 5 & 21 & 2 & 29.2 & 29200 & 29200 & 3.22 & 3.15 \\
\hline 0.75 & 15 & 2 & 49 & 48 & $>2419.6$ & $>24.2$ & $>24.2$ & N/A & N/A \\
\hline 0.75 & 15 & 5 & 3 & 0 & 3.1 & 3100 & 3100 & 4.20 & 4.17 \\
\hline 0.75 & 30 & 2 & 49 & 45 & 1732.9 & 1732.9 & 1732.9 & 4.45 & 4.36 \\
\hline 0.75 & 30 & 5 & 1 & 0 & 1 & 1000 & 1000 & 4.69 & 4.60 \\
\hline 1.5 & 2 & 1 & 49 & 48 & $>2419.6$ & $>24.2$ & $>24.2$ & $\mathrm{~N} / \mathrm{A}$ & $\mathrm{N} / \mathrm{A}$ \\
\hline 1.5 & 2 & 4 & 42 & 7 & 101.7 & 10170 & 10170 & 3.68 & 3.61 \\
\hline 1.5 & 5 & 1 & 49 & 48 & $>2419.6$ & $>24.2$ & $>24.2$ & $\mathrm{~N} / \mathrm{A}$ & $\mathrm{N} / \mathrm{A}$ \\
\hline 1.5 & 5 & 3 & 40 & 2 & 78.5 & 785 & 785 & 4.79 & 4.72 \\
\hline 1.5 & 15 & 1 & 49 & 48 & $>2419.6$ & $>24.2$ & $>24.2$ & N/A & $\mathrm{N} / \mathrm{A}$ \\
\hline 1.5 & 15 & 3 & 24 & 0 & 31.4 & 314 & 314 & 5.19 & 5.17 \\
\hline 1.5 & 30 & 1 & 49 & 48 & $>2419.6$ & $>24.2$ & $>24.2$ & N/A & $\mathrm{N} / \mathrm{A}$ \\
\hline 1.5 & 30 & 3 & 10 & 0 & 11 & 110 & 110 & 5.65 & 5.56 \\
\hline
\end{tabular}




\begin{tabular}{|c|c|c|c|c|c|c|c|c|c|}
\hline Expt \#: & 77 & & & & & & & & \\
\hline Condition: & $+\mathrm{pH}(\mathrm{Alk}$ & line $\mathrm{pH}$ ) & & & & & & & delta \\
\hline Conc.(mg/l) & $\begin{array}{l}\text { time } \\
\text { (min) }\end{array}$ & dilution & $\begin{array}{l}\text { lg wls } \\
\text { pos }\end{array}$ & $\begin{array}{l}\text { sm wls } \\
\text { pos }\end{array}$ & $\begin{array}{l}\text { MPN/ } \\
100 \mathrm{ml}\end{array}$ & $\mathrm{MPN} / \mathrm{ml}$ & $\begin{array}{l}\text { calc } \\
\text { MPN/ml }\end{array}$ & $\begin{array}{l}\text { log } \\
\text { redctn. }\end{array}$ & $\begin{array}{l}\text { log } \\
\text { redctn. }\end{array}$ \\
\hline 0 & 0 & 3 & 49 & 48 & $>2419.6$ & $>24.2$ & $>24.2$ & $\mathrm{~N} / \mathrm{A}$ & \\
\hline 0 & 0 & 5 & 49 & 48 & $>2419.6$ & $>24.2$ & $>24.2$ & $\mathrm{~N} / \mathrm{A}$ & \\
\hline 0 & 0 & 7 & 49 & 30 & 613.1 & 61310000 & 61310000 & $\mathrm{~N} / \mathrm{A}$ & \\
\hline 0 & 2 & 5 & 49 & 48 & $>2419.6$ & $>24.2$ & $>24.2$ & $\mathrm{~N} / \mathrm{A}$ & \\
\hline 0 & 2 & 7 & 49 & 24 & 435.2 & 43520000 & 43520000 & 0.15 & \\
\hline 0 & 5 & 5 & 49 & 48 & $>2419.6$ & $>24.2$ & $>24.2$ & $\mathrm{~N} / \mathrm{A}$ & \\
\hline 0 & 5 & 7 & 49 & 25 & 461.1 & 46110000 & 46110000 & 0.12 & \\
\hline 0 & 15 & 7 & 49 & 48 & $>2419.6$ & $>24.2$ & $>24.2$ & N/A & \\
\hline 0 & 15 & 7 & 49 & 22 & 387.3 & 38730000 & 38730000 & 0.20 & \\
\hline 0 & 30 & 7 & 49 & 48 & $>2419.6$ & $>24.2$ & $>24.2$ & $\mathrm{~N} / \mathrm{A}$ & \\
\hline 0 & 30 & 7 & 49 & 20 & 344.8 & 34480000 & 34480000 & 0.25 & \\
\hline 0.75 & 2 & 3 & 49 & 48 & $>2419.6$ & $>24.2$ & $>24.2$ & $\mathrm{~N} / \mathrm{A}$ & \\
\hline 0.75 & 2 & 5 & 49 & 42 & 1299.7 & 1299700 & 1299700 & 1.67 & 1.52 \\
\hline 0.75 & 5 & 3 & 49 & 48 & $>2419.6$ & $>24.2$ & $>24.2$ & $\mathrm{~N} / \mathrm{A}$ & $\mathrm{N} / \mathrm{A}$ \\
\hline 0.75 & 5 & 5 & 48 & 26 & 360.9 & 360900 & 360900 & 2.23 & 2.11 \\
\hline 0.75 & 15 & 2 & 49 & 48 & $>2419.6$ & $>24.2$ & $>24.2$ & N/A & N/A \\
\hline 0.75 & 15 & 5 & 47 & 5 & 135.4 & 135400 & 135400 & 2.66 & 2.46 \\
\hline 0.75 & 30 & 2 & 49 & 48 & $>2419.6$ & $>24.2$ & $>24.2$ & $\mathrm{~N} / \mathrm{A}$ & $\mathrm{N} / \mathrm{A}$ \\
\hline 0.75 & 30 & 5 & 19 & 1 & 24.6 & 24600 & 24600 & 3.40 & 3.15 \\
\hline 1.5 & 2 & 1 & 49 & 48 & $>2419.6$ & $>24.2$ & $>24.2$ & $\mathrm{~N} / \mathrm{A}$ & $\mathrm{N} / \mathrm{A}$ \\
\hline 1.5 & 2 & 4 & 49 & 36 & 866.4 & 86640 & 86640 & 2.85 & 2.70 \\
\hline 1.5 & 5 & 1 & 49 & 48 & $>2419.6$ & $>24.2$ & $>24.2$ & N/A & N/A \\
\hline 1.5 & 5 & 3 & 49 & 44 & 1553.1 & 15531 & 15531 & 3.60 & 3.47 \\
\hline 1.5 & 15 & 1 & 49 & 48 & $>2419.6$ & $>24.2$ & $>24.2$ & N/A & $\mathrm{N} / \mathrm{A}$ \\
\hline 1.5 & 15 & 3 & 48 & 31 & 360.9 & 3609 & 3609 & 4.23 & 4.03 \\
\hline 1.5 & 30 & 1 & 49 & 48 & $>2419.6$ & $>24.2$ & $>24.2$ & N/A & N/A \\
\hline 1.5 & 30 & 3 & 47 & 11 & 166.4 & 1664 & 1664 & 4.57 & 4.32 \\
\hline
\end{tabular}




\begin{tabular}{|c|c|c|c|c|c|c|c|c|c|}
\hline $\begin{array}{l}\text { Date of } \\
\text { Expt: }\end{array}$ & \multicolumn{9}{|l|}{$8 / 9 / 2005$} \\
\hline Expt \#: & \multicolumn{9}{|c|}{78} \\
\hline Date read: & \multicolumn{9}{|c|}{$8 / 10 / 2005$} \\
\hline Purpose: & \multicolumn{9}{|c|}{ Effect of $\mathrm{pH}$} \\
\hline WS: & \multicolumn{9}{|c|}{ E.coli grown in 5:1 IO:NB for 4 days,spun, washed $\mathrm{X} 3, \&$ resuspended in $5: 1 \mathrm{IO} / \mathrm{diH} 2 \mathrm{O}$} \\
\hline Condition: & \multicolumn{9}{|c|}{$\mathrm{N}($ Normal $\mathrm{pH})$} \\
\hline Conc.(mg/l) & $\begin{array}{l}\text { time } \\
\text { (min) }\end{array}$ & dilution & $\begin{array}{l}\text { lg wls } \\
\text { pos }\end{array}$ & $\begin{array}{l}\text { sm wls } \\
\text { pos }\end{array}$ & $\begin{array}{l}\text { MPN/ } \\
100 \mathrm{ml}\end{array}$ & MPN/ml & $\begin{array}{l}\text { calc } \\
\text { MPN/ml }\end{array}$ & $\begin{array}{l}\text { log } \\
\text { redctn. }\end{array}$ & $\begin{array}{l}\text { delta } \\
\text { log } \\
\text { redctn. }\end{array}$ \\
\hline 0 & 0 & 3 & 49 & 48 & $>2419.6$ & $>24.2$ & $>24.2$ & N/A & \\
\hline 0 & 0 & 5 & 49 & 48 & $>2419.6$ & $>24.2$ & $>24.2$ & $\mathrm{~N} / \mathrm{A}$ & \\
\hline 0 & 0 & 7 & 49 & 22 & 387.3 & 38730000 & 38730000 & N/A & \\
\hline 0 & 2 & 5 & 49 & 48 & $>2419.6$ & $>24.2$ & $>24.2$ & $\mathrm{~N} / \mathrm{A}$ & \\
\hline 0 & 2 & 7 & 49 & 25 & 461.1 & 46110000 & 46110000 & -0.08 & \\
\hline 0 & 5 & 5 & 49 & 48 & $>2419.6$ & $>24.2$ & $>24.2$ & N/A & \\
\hline 0 & 5 & 7 & 49 & 21 & 365.4 & 36540000 & 36540000 & 0.03 & \\
\hline 0 & 15 & 5 & 49 & 48 & $>2419.6$ & $>24.2$ & $>24.2$ & N/A & \\
\hline 0 & 15 & 7 & 49 & 24 & 435.2 & 43520000 & 43520000 & -0.05 & \\
\hline 0 & 30 & 5 & 49 & 48 & $>2419.6$ & $>24.2$ & $>24.2$ & $\mathrm{~N} / \mathrm{A}$ & \\
\hline 0 & 30 & 7 & 48 & 24 & 328.2 & 32820000 & 32820000 & 0.07 & \\
\hline 0.75 & 2 & 3 & 49 & 48 & $>2419.6$ & $>24.2$ & $>24.2$ & N/A & \\
\hline 0.75 & 2 & 5 & 49 & 39 & 1046.2 & 1046200 & 1046200 & 1.57 & 1.64 \\
\hline 0.75 & 5 & 3 & 49 & 48 & $>2419.6$ & $>24.2$ & $>24.2$ & N/A & $\mathrm{N} / \mathrm{A}$ \\
\hline 0.75 & 5 & 5 & 46 & 22 & 217.8 & 217800 & 217800 & 2.25 & 2.22 \\
\hline 0.75 & 15 & 2 & 49 & 48 & $>2419.6$ & $>24.2$ & $>24.2$ & $\mathrm{~N} / \mathrm{A}$ & $\mathrm{N} / \mathrm{A}$ \\
\hline 0.75 & 15 & 5 & 37 & 3 & 69.1 & 69100 & 69100 & 2.75 & 2.80 \\
\hline 0.75 & 30 & 2 & 49 & 48 & $>2419.6$ & $>24.2$ & $>24.2$ & $\mathrm{~N} / \mathrm{A}$ & N/A \\
\hline 0.75 & 30 & 5 & 27 & 1 & 38.9 & 38900 & 38900 & 3.00 & 2.93 \\
\hline 1.5 & 2 & 1 & 49 & 48 & $>2419.6$ & $>24.2$ & $>24.2$ & N/A & $\mathrm{N} / \mathrm{A}$ \\
\hline 1.5 & 2 & 4 & 49 & 34 & 770.1 & 77010 & 77010 & 2.70 & 2.78 \\
\hline 1.5 & 5 & 1 & 49 & 48 & $>2419.6$ & $>24.2$ & $>24.2$ & $\mathrm{~N} / \mathrm{A}$ & $\mathrm{N} / \mathrm{A}$ \\
\hline 1.5 & 5 & 3 & 49 & 39 & 1046.2 & 10462 & 10462 & 3.57 & 3.54 \\
\hline 1.5 & 15 & 1 & 49 & 48 & $>2419.6$ & $>24.2$ & $>24.2$ & $\mathrm{~N} / \mathrm{A}$ & N/A \\
\hline 1.5 & 15 & 3 & 48 & 19 & 260.3 & 2603 & 2603 & 4.17 & 4.22 \\
\hline 1.5 & 30 & 1 & 49 & 48 & $>2419.6$ & $>24.2$ & $>24.2$ & N/A & $\mathrm{N} / \mathrm{A}$ \\
\hline 1.5 & 30 & 3 & 42 & 15 & 126.7 & 1267 & 1267 & 4.49 & 4.41 \\
\hline
\end{tabular}




\begin{tabular}{|c|c|c|c|c|c|c|c|c|c|}
\hline Expt \#: & 78 & & & & & & & & \\
\hline Condition: & $-\mathrm{pH}$ (Acid & $\mathrm{pH})$ & & & & & & & delta \\
\hline Conc.(mg/l) & $\begin{array}{l}\text { time } \\
(\min )\end{array}$ & dilution & $\begin{array}{l}\text { lg wls } \\
\text { pos }\end{array}$ & $\begin{array}{l}\text { sm wls } \\
\text { pos }\end{array}$ & $\begin{array}{l}\text { MPN/ } \\
100 \mathrm{ml}\end{array}$ & $\mathrm{MPN} / \mathrm{ml}$ & $\begin{array}{l}\text { calc } \\
\text { MPN/ml }\end{array}$ & $\begin{array}{l}\text { log } \\
\text { redctn. }\end{array}$ & $\begin{array}{l}\text { log } \\
\text { redctn. }\end{array}$ \\
\hline 0 & 0 & 3 & 49 & 48 & $>2419.6$ & $>24.2$ & $>24.2$ & $\mathrm{~N} / \mathrm{A}$ & \\
\hline 0 & 0 & 5 & 49 & 48 & $>2419.6$ & $>24.2$ & $>24.2$ & $\mathrm{~N} / \mathrm{A}$ & \\
\hline 0 & 0 & 7 & 49 & 26 & 488.4 & 48840000 & 48840000 & $\mathrm{~N} / \mathrm{A}$ & \\
\hline 0 & 2 & 5 & 49 & 48 & $>2419.6$ & $>24.2$ & $>24.2$ & $\mathrm{~N} / \mathrm{A}$ & \\
\hline 0 & 2 & 7 & 49 & 23 & 410.6 & 41060000 & 41060000 & 0.08 & \\
\hline 0 & 5 & 5 & 49 & 48 & $>2419.6$ & $>24.2$ & $>24.2$ & N/A & \\
\hline 0 & 5 & 7 & 49 & 23 & 410.6 & 41060000 & 41060000 & 0.08 & \\
\hline 0 & 15 & 5 & 49 & 48 & $>2419.6$ & $>24.2$ & $>24.2$ & $\mathrm{~N} / \mathrm{A}$ & \\
\hline 0 & 15 & 7 & 49 & 25 & 461.1 & 46110000 & 46110000 & 0.02 & \\
\hline 0 & 30 & 5 & 49 & 48 & $>2419.6$ & $>24.2$ & $>24.2$ & N/A & \\
\hline 0 & 30 & 7 & 48 & 28 & 396.8 & 39680000 & 39680000 & 0.09 & \\
\hline 0.75 & 2 & 3 & 49 & 47 & 2419.6 & 24196 & 24196 & 3.31 & \\
\hline 0.75 & 2 & 5 & 49 & 24 & 435.2 & 435200 & 435200 & 2.05 & 1.97 \\
\hline 0.75 & 5 & 3 & 49 & 48 & $>2419.6$ & $>24.2$ & $>24.2$ & N/A & $\mathrm{N} / \mathrm{A}$ \\
\hline 0.75 & 5 & 5 & 18 & 0 & 21.8 & 21800 & 21800 & 3.35 & 3.27 \\
\hline 0.75 & 15 & 2 & 49 & 48 & $>2419.6$ & $>24.2$ & $>24.2$ & N/A & N/A \\
\hline 0.75 & 15 & 5 & 5 & 1 & 6.3 & 6300 & 6300 & 3.89 & 3.86 \\
\hline 0.75 & 30 & 2 & 49 & 46 & 1986.3 & 1986.3 & 1986.3 & 4.39 & 4.30 \\
\hline 0.75 & 30 & 5 & 2 & 0 & 2 & 2000 & 2000 & 4.39 & 4.30 \\
\hline 1.5 & 2 & 1 & 49 & 48 & $>2419.6$ & $>24.2$ & $>24.2$ & $\mathrm{~N} / \mathrm{A}$ & $\mathrm{N} / \mathrm{A}$ \\
\hline 1.5 & 2 & 4 & 39 & 3 & 76.7 & 7670 & 7670 & 3.80 & 3.73 \\
\hline 1.5 & 5 & 1 & 49 & 48 & $>2419.6$ & $>24.2$ & $>24.2$ & N/A & $\mathrm{N} / \mathrm{A}$ \\
\hline 1.5 & 5 & 3 & 34 & 1 & 55.7 & 557 & 557 & 4.94 & 4.87 \\
\hline 1.5 & 15 & 1 & 49 & 48 & $>2419.6$ & $>24.2$ & $>24.2$ & N/A & $\mathrm{N} / \mathrm{A}$ \\
\hline 1.5 & 15 & 3 & 20 & 1 & 26.2 & 262 & 262 & 5.27 & 5.25 \\
\hline 1.5 & 30 & 1 & 49 & 37 & 920.8 & 92.08 & 92.08 & 5.72 & 5.63 \\
\hline 1.5 & 30 & 3 & 7 & 0 & 7.5 & 75 & 75 & 5.81 & 5.72 \\
\hline
\end{tabular}




\begin{tabular}{|c|c|c|c|c|c|c|c|c|c|}
\hline Expt \#: & 78 & & & & & & & & \\
\hline Condition: & $+\mathrm{pH}$ (Alka & ine $\mathrm{pH}$ ) & & & & & & & delta \\
\hline Conc.(mg/l) & $\begin{array}{l}\text { time } \\
(\min )\end{array}$ & dilution & $\begin{array}{l}\text { lg wls } \\
\text { pos }\end{array}$ & $\begin{array}{l}\text { sm wls } \\
\text { pos }\end{array}$ & $\begin{array}{l}\text { MPN/ } \\
100 \mathrm{ml}\end{array}$ & $\mathrm{MPN} / \mathrm{ml}$ & $\begin{array}{l}\text { calc } \\
\text { MPN/ml }\end{array}$ & $\begin{array}{l}\text { log } \\
\text { redctn. }\end{array}$ & $\begin{array}{l}\text { log } \\
\text { redctn. }\end{array}$ \\
\hline 0 & 0 & 3 & 49 & 48 & $>2419.6$ & $>24.2$ & $>24.2$ & $\mathrm{~N} / \mathrm{A}$ & \\
\hline 0 & 0 & 5 & 49 & 48 & $>2419.6$ & $>24.2$ & $>24.2$ & $\mathrm{~N} / \mathrm{A}$ & \\
\hline 0 & 0 & 7 & 49 & 30 & 613.1 & 61310000 & 61310000 & $\mathrm{~N} / \mathrm{A}$ & \\
\hline 0 & 2 & 5 & 49 & 48 & $>2419.6$ & $>24.2$ & $>24.2$ & $\mathrm{~N} / \mathrm{A}$ & \\
\hline 0 & 2 & 7 & 49 & 24 & 435.2 & 43520000 & 43520000 & 0.15 & \\
\hline 0 & 5 & 5 & 49 & 48 & $>2419.6$ & $>24.2$ & $>24.2$ & $\mathrm{~N} / \mathrm{A}$ & \\
\hline 0 & 5 & 7 & 49 & 25 & 461.1 & 46110000 & 46110000 & 0.12 & \\
\hline 0 & 15 & 7 & 49 & 48 & $>2419.6$ & $>24.2$ & $>24.2$ & N/A & \\
\hline 0 & 15 & 7 & 49 & 22 & 387.3 & 38730000 & 38730000 & 0.20 & \\
\hline 0 & 30 & 7 & 49 & 48 & $>2419.6$ & $>24.2$ & $>24.2$ & $\mathrm{~N} / \mathrm{A}$ & \\
\hline 0 & 30 & 7 & 49 & 20 & 344.8 & 34480000 & 34480000 & 0.25 & \\
\hline 0.75 & 2 & 3 & 49 & 48 & $>2419.6$ & $>24.2$ & $>24.2$ & $\mathrm{~N} / \mathrm{A}$ & \\
\hline 0.75 & 2 & 5 & 49 & 45 & 1732.9 & 1732900 & 1732900 & 1.55 & 1.40 \\
\hline 0.75 & 5 & 3 & 49 & 48 & $>2419.6$ & $>24.2$ & $>24.2$ & $\mathrm{~N} / \mathrm{A}$ & $\mathrm{N} / \mathrm{A}$ \\
\hline 0.75 & 5 & 5 & 49 & 28 & 547.5 & 547500 & 547500 & 2.05 & 1.93 \\
\hline 0.75 & 15 & 2 & 49 & 48 & $>2419.6$ & $>24.2$ & $>24.2$ & N/A & N/A \\
\hline 0.75 & 15 & 5 & 47 & 5 & 135.4 & 135400 & 135400 & 2.66 & 2.46 \\
\hline 0.75 & 30 & 2 & 49 & 48 & $>2419.6$ & $>24.2$ & $>24.2$ & $\mathrm{~N} / \mathrm{A}$ & $\mathrm{N} / \mathrm{A}$ \\
\hline 0.75 & 30 & 5 & 14 & 3 & 19.7 & 19700 & 19700 & 3.49 & 3.24 \\
\hline 1.5 & 2 & 1 & 49 & 48 & $>2419.6$ & $>24.2$ & $>24.2$ & $\mathrm{~N} / \mathrm{A}$ & $\mathrm{N} / \mathrm{A}$ \\
\hline 1.5 & 2 & 4 & 49 & 26 & 488.4 & 48840 & 48840 & 3.10 & 2.95 \\
\hline 1.5 & 5 & 1 & 49 & 48 & $>2419.6$ & $>24.2$ & $>24.2$ & N/A & N/A \\
\hline 1.5 & 5 & 3 & 49 & 30 & 613.1 & 6131 & 6131 & 4.00 & 3.88 \\
\hline 1.5 & 15 & 1 & 49 & 48 & $>2419.6$ & $>24.2$ & $>24.2$ & $\mathrm{~N} / \mathrm{A}$ & N/A \\
\hline 1.5 & 15 & 3 & 48 & 14 & 209.8 & 2098 & 2098 & 4.47 & 4.27 \\
\hline 1.5 & 30 & 1 & 49 & 48 & $>2419.6$ & $>24.2$ & $>24.2$ & N/A & N/A \\
\hline 1.5 & 30 & 3 & 40 & 4 & 83.3 & 833 & 833 & 4.87 & 4.62 \\
\hline
\end{tabular}




\section{E.10 Anti-Clumping Measures}

\begin{tabular}{|c|c|c|c|c|c|c|c|c|}
\hline $\begin{array}{l}\text { Date of } \\
\text { Expt: }\end{array}$ & \multicolumn{8}{|c|}{$12 / 13 / 2005$} \\
\hline Expt \#: & \multicolumn{8}{|c|}{98} \\
\hline Date read: & \multicolumn{8}{|c|}{$12 / 14 / 2005$} \\
\hline Purpose: & \multicolumn{8}{|c|}{ Effect of anti-clumping measures } \\
\hline WS: & \multicolumn{8}{|c|}{$\begin{array}{l}\text { E.coli grown in 5:1 IO:NB for } 5 \text { days,spun, washed } X 3 \text { and resuspended in 5:1 } \\
\mathrm{IO} / \mathrm{diH} 2 \mathrm{O}\end{array}$} \\
\hline Condition: & \multicolumn{8}{|c|}{$\mathrm{N}$ (Normal preparation) } \\
\hline \multirow[b]{2}{*}{ Conc.(mg/l) } & \multirow{2}{*}{$\begin{array}{l}\text { time } \\
(\min )\end{array}$} & & \multirow{2}{*}{$\begin{array}{l}\lg \text { wls } \\
\text { pos }\end{array}$} & \multirow{2}{*}{$\begin{array}{l}\text { sm wls } \\
\text { pos }\end{array}$} & \multirow{2}{*}{$\begin{array}{l}\text { MPN/ } \\
100 \mathrm{ml}\end{array}$} & & \multirow{2}{*}{$\begin{array}{l}\text { calc } \\
\text { MPN/ml }\end{array}$} & \multirow{2}{*}{$\begin{array}{l}\log \\
\text { redctn. }\end{array}$} \\
\hline & & dilution & & & & $\mathrm{MPN} / \mathrm{ml}$ & & \\
\hline 0 & 0 & nd & nd & nd & nd & nd & nd & $\mathrm{N} / \mathrm{A}$ \\
\hline 0 & 0 & 5 & 49 & 42 & 1299.7 & 1299700 & 1299700 & $\mathrm{~N} / \mathrm{A}$ \\
\hline 0 & 0 & 7 & 15 & 0 & 17.5 & 1750000 & 1750000 & $\mathrm{~N} / \mathrm{A}$ \\
\hline 0.75 & 1 & 3 & 49 & 48 & $>2419.6$ & $>24.2$ & $>24.2$ & $\mathrm{~N} / \mathrm{A}$ \\
\hline 0.75 & 1 & 6 & 7 & 1 & 8.5 & 85000 & 85000 & 1.25 \\
\hline 0.75 & 2 & 3 & 49 & 43 & 1413.6 & 14136 & 14136 & 2.03 \\
\hline 0.75 & 2 & 6 & 1 & 0 & 1 & 10000 & 10000 & 2.18 \\
\hline 0.75 & 3 & 3 & 49 & 37 & 920.8 & 9208 & 9208 & 2.22 \\
\hline 0.75 & 3 & 6 & 0 & 0 & 0 & 0 & 10000 & 2.18 \\
\hline 0.75 & 5 & 3 & 49 & 24 & 435.2 & 4352 & 4352 & 2.54 \\
\hline 0.75 & 5 & 6 & 0 & 0 & 0 & 0 & 10000 & 2.18 \\
\hline 0.75 & 15 & 3 & 49 & 23 & 410.6 & 4106 & 4106 & 2.57 \\
\hline 0.75 & 15 & 6 & 0 & 0 & 0 & 0 & 10000 & 2.18 \\
\hline 0.75 & 30 & 3 & 48 & 22 & 298.7 & 2987 & 2987 & 2.71 \\
\hline 1.5 & 1 & 2 & nd & nd & nd & nd & nd & nd \\
\hline 1.5 & 1 & 4 & 30 & 2 & 47.1 & 4710 & 4710 & 2.51 \\
\hline 1.5 & 2 & 3 & 41 & 5 & 90.6 & 906 & 906 & 3.23 \\
\hline 1.5 & 3 & 3 & 32 & 2 & 52.1 & 521 & 521 & 3.47 \\
\hline 1.5 & 5 & 3 & 28 & 3 & 44.1 & 441 & 441 & 3.54 \\
\hline 1.5 & 15 & 3 & 20 & 4 & 30.1 & 301 & 301 & 3.70 \\
\hline 1.5 & 30 & 3 & 12 & 0 & 13.5 & 135 & 135 & 4.05 \\
\hline 3 & 1 & 3 & 48 & 18 & 248.9 & 2489 & 2489 & 2.79 \\
\hline 3 & 1 & 5 & nd & nd & nd & nd & nd & nd \\
\hline 3 & 2 & 3 & 24 & 1 & 33.1 & 331 & 331 & 3.66 \\
\hline 3 & 2 & 5 & nd & nd & nd & $\mathrm{nd}$ & nd & nd \\
\hline 3 & 3 & 2 & 46 & 9 & 142.1 & 142.1 & 142.1 & 4.03 \\
\hline 3 & 5 & 2 & 37 & 10 & 84.2 & 84.2 & 84.2 & 4.26 \\
\hline 3 & 15 & 2 & 35 & 1 & 58.6 & 58.6 & 58.6 & 4.42 \\
\hline 3 & 30 & 2 & 17 & 2 & 22.8 & 22.8 & 22.8 & 4.83 \\
\hline 4 & 1 & 3 & 36 & 8 & 75.9 & 759 & 759 & 3.30 \\
\hline 4 & 1 & 2 & nd & nd & nd & nd & nd & nd \\
\hline 4 & 2 & 3 & 25 & 2 & 36.4 & 364 & 364 & 3.62 \\
\hline 4 & 2 & 2 & nd & nd & nd & nd & nd & nd \\
\hline 4 & 3 & 2 & 36 & 5 & 69.7 & 69.7 & 69.7 & 4.34 \\
\hline 4 & 5 & 2 & 24 & 6 & 40.2 & 40.2 & 40.2 & 4.58 \\
\hline 4 & 15 & 1 & 46 & 17 & 184.2 & 18.42 & 18.42 & 4.92 \\
\hline
\end{tabular}




\begin{tabular}{|c|c|c|c|c|c|c|c|c|}
\hline Expt \#: & 98 & & & & & & & \\
\hline Condition: & Anti-clum & ing/Low-s & beed cent & fugation & & & & \\
\hline Conc.(mg/l) & $\begin{array}{l}\text { time } \\
(\min )\end{array}$ & dilution & $\begin{array}{l}\text { lg wls } \\
\text { pos }\end{array}$ & $\begin{array}{l}\text { sm wls } \\
\text { pos }\end{array}$ & $\begin{array}{l}\text { MPN/ } \\
100 \mathrm{ml}\end{array}$ & MPN/ml & $\begin{array}{l}\text { calc } \\
\text { MPN/ml }\end{array}$ & $\begin{array}{l}\text { log } \\
\text { redctn. }\end{array}$ \\
\hline 0 & 0 & $\mathrm{nd}$ & $\mathrm{nd}$ & $\mathrm{nd}$ & $\mathrm{nd}$ & nd & nd & $N / A$ \\
\hline 0 & 0 & 6 & 49 & 26 & 488.4 & 4884000 & 4884000 & $\mathrm{~N} / \mathrm{A}$ \\
\hline 0 & 0 & 3 & 49 & 48 & $>2419.6$ & $>24.2$ & $>24.2$ & N/A \\
\hline 0.75 & 1 & 3 & 49 & 48 & $>2419.6$ & $>24.2$ & $>24.2$ & N/A \\
\hline 0.75 & 1 & 6 & 3 & 0 & 3.1 & 31000 & 31000 & 2.20 \\
\hline 0.75 & 2 & 3 & 49 & 48 & $>2419.6$ & $>24.2$ & $>24.2$ & $\mathrm{~N} / \mathrm{A}$ \\
\hline 0.75 & 2 & 6 & 2 & 0 & 2 & 20000 & 20000 & 2.39 \\
\hline 0.75 & 3 & 3 & 49 & 46 & 1986.3 & 19863 & 19863 & 2.39 \\
\hline 0.75 & 3 & 6 & 0 & 0 & 0 & 0 & 10000 & 2.69 \\
\hline 0.75 & 5 & 3 & 49 & 43 & 1413.6 & 14136 & 14136 & 2.54 \\
\hline 0.75 & 5 & 6 & 0 & 0 & 0 & 0 & 10000 & 2.69 \\
\hline 0.75 & 15 & 2 & 49 & 48 & $>2419.6$ & $>24.2$ & $>24.2$ & $\mathrm{~N} / \mathrm{A}$ \\
\hline 0.75 & 15 & 5 & 14 & 0 & 16.1 & 16100 & 16100 & 2.48 \\
\hline 0.75 & 30 & 3 & 49 & 32 & 686.7 & 6867 & 6867 & 2.85 \\
\hline 1.5 & 1 & 2 & nd & nd & nd & nd & nd & nd \\
\hline 1.5 & 1 & 3 & 49 & 44 & 1553.1 & 15531 & 15531 & 2.50 \\
\hline 1.5 & 2 & 2 & 49 & 46 & 1986.3 & 1986.3 & 1986.3 & 3.39 \\
\hline 1.5 & 3 & 2 & 49 & 17 & 290.9 & 290.9 & 290.9 & 4.23 \\
\hline 1.5 & 5 & 2 & 49 & 17 & 290.9 & 290.9 & 290.9 & 4.23 \\
\hline 1.5 & 15 & 2 & 46 & 14 & 167 & 167 & 167 & 4.47 \\
\hline 1.5 & 30 & 2 & 44 & 15 & 145.5 & 145.5 & 145.5 & 4.53 \\
\hline 3 & 1 & 2 & 49 & 46 & 1986.3 & 1986.3 & 1986.3 & 3.39 \\
\hline 3 & 1 & 5 & nd & nd & nd & nd & nd & nd \\
\hline 3 & 2 & 2 & 48 & 18 & 248.9 & 248.9 & 248.9 & 4.29 \\
\hline 3 & 2 & 5 & nd & nd & nd & nd & nd & nd \\
\hline 3 & 3 & 2 & 23 & 3 & 34.1 & 34.1 & 34.1 & 5.16 \\
\hline 3 & 5 & 2 & 20 & 4 & 30.1 & 30.1 & 30.1 & 5.21 \\
\hline 3 & 15 & 2 & 16 & 1 & 20.1 & 20.1 & 20.1 & 5.39 \\
\hline 3 & 30 & 1 & 44 & 8 & 118.7 & 11.87 & 11.87 & 5.61 \\
\hline 4 & 1 & 2 & 46 & 18 & 190.4 & 190.4 & 190.4 & 4.41 \\
\hline 4 & 1 & 2 & nd & nd & nd & nd & nd & nd \\
\hline 4 & 2 & 2 & 31 & 5 & 54.6 & 54.6 & 54.6 & 4.95 \\
\hline 4 & 2 & 2 & nd & nd & nd & nd & nd & nd \\
\hline 4 & 3 & 2 & 22 & 0 & 28.2 & 28.2 & 28.2 & 5.24 \\
\hline 4 & 5 & 1 & 48 & 17 & 238.2 & 23.82 & 23.82 & 5.31 \\
\hline 4 & 15 & 1 & 46 & 6 & 129.1 & 12.91 & 12.91 & 5.58 \\
\hline
\end{tabular}




\begin{tabular}{|c|c|c|c|c|c|c|c|c|}
\hline $\begin{array}{l}\text { Date of } \\
\text { Expt: }\end{array}$ & \multicolumn{8}{|c|}{$12 / 13 / 2005$} \\
\hline Expt \#: & \multicolumn{8}{|c|}{99} \\
\hline Date read: & \multicolumn{8}{|c|}{$12 / 14 / 2005$} \\
\hline Purpose: & \multicolumn{8}{|c|}{ Effect of anti-clumping measures } \\
\hline WS: & \multicolumn{8}{|c|}{$\begin{array}{l}\text { E.coli grown in 5:1 IO:NB for } 5 \text { days,spun, washed } X 3 \text { and resuspended in 5:1 } \\
1 \mathrm{O} / \mathrm{diH} 2 \mathrm{O}\end{array}$} \\
\hline Condition: & \multicolumn{8}{|c|}{$\mathrm{N}$ (Normal preparation) } \\
\hline Conc.(mg/l) & $\begin{array}{l}\text { time } \\
(\min )\end{array}$ & dilution & $\begin{array}{l}\lg \text { wls } \\
\text { pos }\end{array}$ & $\begin{array}{l}\text { sm wls } \\
\text { pos }\end{array}$ & $\begin{array}{l}\text { MPN/ } \\
100 \mathrm{ml}\end{array}$ & MPN/ml & $\begin{array}{l}\text { calc } \\
\text { MPN/ml }\end{array}$ & $\begin{array}{l}\text { log } \\
\text { redctn. }\end{array}$ \\
\hline 0 & 0 & nd & nd & nd & nd & nd & nd & $\mathrm{N} / \mathrm{A}$ \\
\hline 0 & 0 & 3 & 49 & 48 & $>2419.6$ & $>24.2$ & $>24.2$ & $\mathrm{~N} / \mathrm{A}$ \\
\hline 0 & 0 & 5 & 49 & 21 & 365.4 & 365400 & 365400 & 0.00 \\
\hline 0.75 & 1 & 3 & 48 & 45 & 870.4 & 8704 & 8704 & 1.62 \\
\hline 0.75 & 1 & 6 & 5 & 1 & 6.3 & 63000 & 63000 & 0.76 \\
\hline 0.75 & 2 & 3 & 47 & 43 & 571.7 & 5717 & 5717 & 1.81 \\
\hline 0.75 & 2 & 6 & 0 & 0 & 0 & 0 & 10000 & 1.56 \\
\hline 0.75 & 3 & 3 & 47 & 31 & 357.8 & 3578 & 3578 & 2.01 \\
\hline 0.75 & 3 & 6 & 0 & 0 & 0 & 0 & 10000 & 1.56 \\
\hline 0.75 & 5 & 3 & 47 & 22 & 249.5 & 2495 & 2495 & 2.17 \\
\hline 0.75 & 5 & 6 & 0 & 0 & 0 & 0 & 10000 & 1.56 \\
\hline 0.75 & 15 & 3 & 45 & 19 & 177.9 & 1779 & 1779 & 2.31 \\
\hline 0.75 & 15 & 6 & 0 & 0 & 0 & 0 & 10000 & 1.56 \\
\hline 0.75 & 30 & 3 & 44 & 17 & 154.1 & 1541 & 1541 & 2.37 \\
\hline 1.5 & 1 & 2 & nd & nd & nd & nd & nd & nd \\
\hline 1.5 & 1 & 4 & 47 & 30 & 343.6 & 34360 & 34360 & 1.03 \\
\hline 1.5 & 2 & 3 & 42 & 20 & 144.5 & 1445 & 1445 & 2.40 \\
\hline 1.5 & 3 & 3 & 39 & 14 & 103.6 & 1036 & 1036 & 2.55 \\
\hline 1.5 & 5 & 3 & 35 & 9 & 74.3 & 743 & 743 & 2.69 \\
\hline 1.5 & 15 & 3 & 17 & 0 & 20.3 & 203 & 203 & 3.26 \\
\hline 1.5 & 30 & 3 & 10 & 0 & 10 & 100 & 100 & 3.56 \\
\hline 3 & 1 & 3 & 47 & 12 & 172.3 & 1723 & 1723 & 2.33 \\
\hline 3 & 1 & 5 & nd & nd & nd & nd & nd & nd \\
\hline 3 & 2 & 3 & nd & nd & nd & nd & nd & nd \\
\hline 3 & 2 & 5 & nd & nd & nd & nd & nd & nd \\
\hline 3 & 3 & 2 & 46 & 6 & 129.1 & 129.1 & 129.1 & 3.45 \\
\hline 3 & 5 & 2 & 32 & 9 & 64.5 & 64.5 & 64.5 & 3.75 \\
\hline 3 & 15 & 2 & 26 & 0 & 35.5 & 35.5 & 35.5 & 4.01 \\
\hline 3 & 30 & 2 & 11 & 1 & 13.4 & 13.4 & 13.4 & 4.44 \\
\hline 4 & 1 & 3 & 44 & 18 & 158.5 & 1585 & 1585 & 2.36 \\
\hline 4 & 1 & 2 & nd & nd & nd & nd & nd & nd \\
\hline 4 & 2 & 3 & nd & nd & nd & nd & nd & nd \\
\hline 4 & 2 & 2 & 32 & 3 & 53.8 & 53.8 & 53.8 & 3.83 \\
\hline 4 & 3 & 2 & 29 & 2 & 44.8 & 44.8 & 44.8 & 3.91 \\
\hline 4 & 5 & 2 & 20 & 0 & 24.9 & 24.9 & 24.9 & 4.17 \\
\hline 4 & 15 & 1 & 29 & 0 & 41.6 & 4.16 & 4.16 & 4.94 \\
\hline
\end{tabular}




\begin{tabular}{|c|c|c|c|c|c|c|c|c|}
\hline Expt \#: & 99 & & & & & & & \\
\hline Condition: & Anti-clum & ing/Vortes & ing & & & & & \\
\hline Conc.(mg/l) & $\begin{array}{l}\text { time } \\
(\min )\end{array}$ & dilution & $\begin{array}{l}\text { lg wls } \\
\text { pos }\end{array}$ & $\begin{array}{l}\text { sm wls } \\
\text { pos }\end{array}$ & $\begin{array}{l}\text { MPN/ } \\
100 \mathrm{ml}\end{array}$ & MPN/ml & $\begin{array}{l}\text { calc } \\
\text { MPN/ml }\end{array}$ & $\begin{array}{l}\log \\
\text { redctn. }\end{array}$ \\
\hline 0 & 0 & $\mathrm{nd}$ & $\mathrm{nd}$ & $\mathrm{nd}$ & $\mathrm{nd}$ & $\mathrm{nd}$ & $\mathrm{nd}$ & $\mathrm{N} / \mathrm{A}$ \\
\hline 0 & 0 & 5 & 49 & 21 & 365.4 & 365400 & 365400 & $\mathrm{~N} / \mathrm{A}$ \\
\hline 0 & 0 & 3 & 49 & 48 & $>2419.6$ & $>24.2$ & $>24.2$ & $\mathrm{~N} / \mathrm{A}$ \\
\hline 0.75 & 1 & 3 & 49 & 45 & 1732.87 & 17328.7 & 17328.7 & 1.32 \\
\hline 0.75 & 1 & 6 & 47 & 36 & 436.6 & 4366000 & 4366000 & -1.08 \\
\hline 0.75 & 2 & 3 & 49 & 43 & 1413.6 & 14136 & 14136 & 1.41 \\
\hline 0.75 & 2 & 6 & 3 & 0 & 0 & 0 & 10000 & 1.56 \\
\hline 0.75 & 3 & 3 & 43 & 33 & 219.8 & 2198 & 2198 & 2.22 \\
\hline 0.75 & 3 & 6 & 0 & 0 & 0 & 0 & 10000 & 1.56 \\
\hline 0.75 & 5 & 3 & 39 & 19 & 117.4 & 1174 & 1174 & 2.49 \\
\hline 0.75 & 5 & 6 & 0 & 0 & 0 & 0 & 10000 & 1.56 \\
\hline 0.75 & 15 & 2 & 47 & 15 & 191.8 & 191.8 & 191.8 & 3.28 \\
\hline 0.75 & 15 & 5 & 0 & 0 & 0 & 0 & 1000 & 2.56 \\
\hline 0.75 & 30 & 3 & 21 & 4 & 31.8 & 318 & 318 & 3.06 \\
\hline 1.5 & 1 & 2 & nd & nd & nd & nd & nd & nd \\
\hline 1.5 & 1 & 4 & 49 & 32 & 686.7 & 68670 & 68670 & 0.73 \\
\hline 1.5 & 2 & 3 & 43 & 11 & 121.1 & 1211 & 1211 & 2.48 \\
\hline 1.5 & 3 & 3 & 31 & 5 & 52.9 & 529 & 529 & 2.84 \\
\hline 1.5 & 5 & 3 & 11 & 1 & 13.4 & 134 & 134 & 3.44 \\
\hline 1.5 & 15 & 3 & 0 & 0 & 0 & 0 & 10 & 4.56 \\
\hline 1.5 & 30 & 3 & 0 & 0 & 0 & 0 & 10 & 4.56 \\
\hline 3 & 1 & 3 & 48 & 29 & 436 & 4360 & 4360 & 1.92 \\
\hline 3 & 1 & 5 & nd & nd & nd & nd & nd & nd \\
\hline 3 & 2 & 3 & 48 & 17 & 238.2 & 2382 & 2382 & 2.19 \\
\hline 3 & 2 & 5 & nd & nd & nd & nd & nd & $\mathrm{nd}$ \\
\hline 3 & 3 & 2 & 19 & 2 & 24.6 & 24.6 & 24.6 & 4.17 \\
\hline 3 & 5 & 2 & 11 & 0 & 12.2 & 12.2 & 12.2 & 4.48 \\
\hline 3 & 15 & 2 & 0 & 0 & 0 & 0 & 1 & 5.56 \\
\hline 3 & 30 & 1 & 0 & 0 & 0 & 0 & 0.1 & 6.56 \\
\hline 4 & 1 & 3 & 44 & 21 & 172.7 & 1727 & 1727 & 2.33 \\
\hline 4 & 1 & 2 & nd & nd & nd & nd & nd & nd \\
\hline 4 & 2 & 2 & 19 & 9 & 34 & 34 & 34 & 4.03 \\
\hline 4 & 2 & 2 & nd & nd & nd & nd & nd & nd \\
\hline 4 & 3 & 2 & 4 & 3 & 7.2 & 7.2 & 7.2 & 4.71 \\
\hline 4 & 5 & 2 & 1 & 0 & 1 & 1 & 1 & 5.56 \\
\hline 4 & 15 & 1 & 0 & 0 & 0 & 0 & 0.1 & 6.56 \\
\hline
\end{tabular}




\section{LIST OF REFERENCES}

American Water Works Assn., 1999. Water Quality and Treatment: A Handbook of Community Water Supplies, $5^{\text {th }}$ ed.; McGraw-Hill, Inc.: NY, NY.

Azanza, M.P.V., Azanza, R.V., Gedaria, A.I., Sententa, H.G., Idjao, M.V., 2001. Decimal reduction times of Pyrodinium bahamense var compressum and Escherichia coli in chlorine- and ultraviolet-treated seawater. Letters in Appl. Microbiol. 33, 371376.

Bai, M.; Zhang, Z., Bai, X., Zhou, X., Deng, S., Wang, N., 2003. The killing of microorganisms in ship as ballast water using hydroxyl radicals. Oceanologia et Limnolgia Sinica 34, 484-489.

Basu, A., Williams, K.R., Modak, M.J., 1987. Ferrate oxidation of Escherichia coli DNA polymerase-I. J. Biol. Chem. 262, 9601-9607.

Bolster, C.H., Bromley, J.M., Jones, S.H., 2005. Recovery of chlorine-exposed Escherichia coli in estuarine microcosms. Environ. Sci. Technol. 39, 3083-3089.

Brock, T.D., Madigan, M.T., Martinko, J.M., Parker,J., 1994. Biology of Microorganisms, $7^{\text {th }}$ ed. Prentice Hall, Englewood Cliffs, NY. 
Cohen, G.N., 2004. Microbial Biochemistry. Kluwer Acad. Pubs., Boston.

Crichton, R., 2001. Inorganic Biochemistry of Iron Metabolism: From Molecular Mechanisms to Clinical Consequences, $2^{\text {nd }}$ ed. John Wiley \& Sons, NY.

Carlton, J.T., Reid, D., van Leeuwen, H., 1995. The Role of Shipping in the Introduction of Nonindigenous Aquatic Organisms to the Coastal Waters of the United States (other than the Great Lakes) and an Analysis of Control Options (Tech. Rep. No. CG-D11-95, US Coast Guard, Washington DC) in Ruiz, G.M., Rawlings, T.K., Dobbs, F.C., Drake, L.A., Mullady, T., Huq, A., Colwell, R.R., 2000. Global spread of microorganisms by ships. Nature 408, 49-50.

Carlton, J.T., Geller, J.B.,1993. Ecological roulette: The global transport of nonindigenous marine organisms. Science 261, 78-82.

Debarbieux, L., Wandersman, C., 2004. Hemophore-dependent heme acquisition systems, pp 38-47 in Iron Transport in Bacteria, Crosa, J.H., Mey, A.R., Payne, S.M., eds. ASM Press, Wash., DC.

Di Lorenzo, M., Stork, M., Alice, A.F., Lopez, C.S., Crosa, J.H., 2004. Vibrio, pp 241255 in Iron Transport in Bacteria, Crosa, J.H., Mey, A.R., Payne, S.M., eds. ASM Press, Wash., DC. 
Duce, R.A., Tindale, N.W., 1991. Atmospheric transport of iron and its deposition in the ocean. Limnol. Oceangr. 36, 1715-1726, in Microbial Ecology of the Oceans, Kirchman, D.L., ed., 2000, Wiley-Liss, NY.

Emerick, R.W., Loge, F.J., Ginn, T., Darby, J.L., 2000. Modeling the inactivation of particle-associated coliform bacteria. Water Environ. Res. 72, 432-438.

Escobar, I.C., Randall, A.A., Taylor, J.S., 2001. Bacterial growth in distribution systems: effect of assimilable organic carbon and biodegradable dissolved organic carbon. Environ. Sci. Technol. 35, 3442-3447.

Falkowski, P.G., 1995. Towards understanding the molecular ecology of phytoplankton photosynthesis, pp 17-38 in Molecular Ecology of Aquatic Microbes, I Joint, ed. Springer-Verlag, NY.

Florida Department of Environmental Protection, 2006. Surface Water Quality Standards, Chapter 62-302. http://www.dep.state.fl.us/legal/Rules/shared/62-302.pdf (accessed March 2006).

Gerba, C.P., Nwachuku, N., Riley, K.R., 2003. Disinfection resistance of waterborne pathogens on the United States Environmental Protection Agency's Contaminant Candidate List (CCL). Aqua 52, 81-94. 
Greets, N.V., Fomichev, A.Y., 1985. The dependence of ozone antibacterial and antiphage action on the concentration of cells and phage particles in the reaction medium. Mickrobiologiya 54, 410-413.

Gyurek, L.L., Finch, G.R., 1998. Modeling water treatment chemical disinfection kinetics. J. Environ. Eng. 124, 783-793.

Haas, C.N., 1981. Rational approaches in the analysis of chemical disinfection kinetics. Chemistry in Water Reuse, Vol. 1, Ann Arbor Science, Ann Arbor, MI.

Haas, C.N., 1979. Kinetics of bacterial deactivation with chlorine. J. Environ. Eng. 105, 1198-1199.

Haas, C.N., Heath, M., Jacangelo, J., Anmangandla, U., Joffe, J., Hornberger, J.C., Glicker, J., 1994. Development and validation of rational design methods of disinfection. American Water Works Assn. and AWWA Research Foundation, Denver, CO.

Haas, C.N., Joffe, J., 1994. Disinfection under dynamic donditions: Modification of Hom's model for decay. Environ. Sci. Technol., 28, 1367-1369.

Haas, C.N., Karra, S.B.,1984. Kinetics of microbial inactivation by chlorine: Review of results in demand-free systems. Water Res., 18, 1443-1449. 
Haas, C.N., Kaymak, B., 2003. Effect of initial microbial density on inactivation of Giardia muris by ozone. Water. Res. 37, 2980-2988.

Hassen, A., Heyouni, A., Shayeb, H., Cherif, M., Boudabous, A., 2000. Inactivation of indicator bacteria in wastewater by chlorine-a kinetics study. Biores. Tech. 72, $85-93$.

Hebert, P. D. N., Muncaster, B.W., Mackie, G. L., 1989. Ecological and genetic studies on Dreissena polymorpha (Pallas): A new mollusc in the Great Lakes. Can. J. Fish. Aquat. Sci., 46, 1587-1591.

Hom,L.W., 1972. Kinetics of chlorine disinfection in an ecosystem. J. Sanit. Eng. Div. Am. Soc. Civ. Engrs. 98, 183-193.

Helsel, D.R., Hirsch, R.M., 2002. Statistical Methods in Water Resources, Chapter 3 in the Techniques of Water-Resources Investigations of the United States Geological Survey, Book 4, Hydrologic Analysis and Interpretation. http://water.usgs.gov/pubs/twri/twri4a3 (accessed January 2006).

Hulsmann, N., Galil, B.S., 2001. The effects of freshwater flushing on marine heterotrophic protists - Implications for ballast water management. Marine Pollution Bulletin 42, 1082-1086. 
Jiang, J.-Q., Lloyd, B., 2002. Review: Progress in the development and use of ferrate salt as an oxidant and coagulant for water and wastewater treatment. Water Res. 36, 1397-1408.

Joachimsthal, E.L., Ivanov, V., Tay, J.-H., Tay, S.T.-L., 2004. Bacteriological examination of ballast water in Singapore Harbour by flow cytometry with FISH. Marine Pollution Bulletin 49, 334-343.

Joachimsthal, E.L., Ivanov, V., Tay, J.-H., Tay, S.T.-L., 2003. Flow cytometry and conventional enumeration of microorganisms in ships' ballast water and marine samples. Marine Pollution Bulletin 46, 308-313.

Kirchman, D.L., 2000. Uptake and Regeneration of Inorganic Nutrients by Marine Heterotrophic Bacteria, pp 261-288 in Kirchman, D.L., ed., Microbial Ecology of the Oceans. Wiley-Liss: NY, NY.

Kovalak, W.P., Longton, G.D., Smithee, D., 1993. Infestation of Power Plant Water Systems by the Zebra Mussel (Dreissena polymorpha pallas) in Nalepa, T.F.; Schloesser, D.W. eds., Zebra Mussels: Biology, Impacts, and Control. Lewis Pub.: Boca Raton, FL. 
Jegatheesan, V., Kastl, G., Fisher, I., Chandy, J., Angles, M., 2004. Modeling bacterial growth in drinking water: Effect of nutrients. J. Am. Water Works Assoc. 96, 129-141.

Lee, Y., Cho, M., Kim, J.Y., Yoon, J., 2004. Chemistry of ferrate (Fe(VI)) in aqueous solution and its applications as a green chemical. J. Ind. Eng. Chem. 10, 161-171.

Lehninger, A.L., 1982. Principles of Biochemistry. Worth Pub., NY.

Mann, N.H., 1995. How do cells express nutrient limitation at the molecular level? pp 171-190 in Molecular Ecology of Aquatic Microbes, Joint, I., ed. SpringerVerlag, NY.

Matheickal, J., Selvakumar, P., Weitz, F., Mahmud, H., Daly, L., Reinhart, D.R.; Sharma, V.K., Ching Thin, L.L., 2004. “Singapore's R\&D efforts in developing innovative ballast water treatment technology with a special emphasis on Fe-VI (Ferrate) as a potential secondary disinfection chemical," presented at the Ballast Water Treatment Symposium, Singapore, May 2004.

McCarthy, S.A., Khambaty, F.M., 1994. International Dissemination of Epidemic Vibrio cholerae by Cargo Ship Ballast and Other Nonpotable Waters. Appl. \& Environ. Microbiol. 60, 2597-2601. 
Metcalf \& Eddy, Inc., 2003. Wastewater Engineering: Treatment and Reuse, $4^{\text {th }}$ ed. McGraw-Hill, NY.

Nathanson, N., Langmuir, A.D., 1963. The Cutter Incident: Poliomyelitis following formaldehyde-inactivated poliovirus vaccination in the United States during the spring of 1955. II. Relationship of poliomyelitis to Cutter vaccine. American Journal of Epidemiology 78:29-60.

Norton, C.D., LeChevallier, M.W., Falkinham, J.O., 2004. Survival of Mycobacterium avium in a model distribution system. Water Res. 38:1457-1466.

Oemcke, D., Parker, N., Mountfort, D., 2004. Effect of UV irradiation on viability of micro scale and resistant forms of marine organisms: Implications for the treatment of ships' ballast water. J. Marine Environ. Eng. 7, 153-171.

Oemcke, D., van Leeuwen, J., 2005. Ozonation of the marine dinoflagellate alga Amphidium sp-Implications for ballast water disinfection. Water Res. 39, 51195125.

Page, D.W., van Leeuwen, J.A., Spark, K.M., Drikas, M., Withers, N., D.E. Mulcahy, 2002. Effect of alum treatment on the trihalomethane formation and bacterial regrowth potential of natural and synthetic waters. Water Res. 36, 4884-4892. 
Perfiliev, Y.D., Sharma, V.K., 2004. Ferrate (VI) synthesis: Dry and wet methods. Proceedings of the International Symposium Innovative Ferrate(VI) Technology in Water and Wastewater Treatment; Prague, Czech Republic, May 31; ICT Press, Institut of Chem. Tech., Prague, 32-37.

Propato, M., Uber, J.G., 2004. Vulnerability of water distribution systems to pathogen intrusion: How effective is a disinfectant residual? Environ. Sci. Technol. 38, $3713-3722$.

Qualls, R.G., Johnson, J.D., 1985. Modelling and efficiency of ultraviolet disinfection systems. Water Res. 19, 1039-1046.

Raaymakers, S., 2001. $1^{\text {st }}$ International Ballast Water Treatment Standards Workshop Report, March 28-30, 2001, report. http://globallast.imo.org (accessed March 2006).

Raymond, K.N., Dertz, E.A, 2004. Biochemical and Physical Properties of Siderophores, pp 3-17 in Iron Transport in Bacteria, JH Crosa, AR Mey, and SM Payne, eds. ASM Press, Wash., DC.

Rennecker, J.L., Kim, J.-H., Corona-Vasquez, B., Marinas, B.J., 2001. Role of disinfectant concentration and $\mathrm{pH}$ in the inactivation kinetics of Cryptosporidium 
parvum oocysts with ozone and monochloramine. Environ. Sci. Technol. 35, $2752-2757$.

Rigby, G.R., Hallegraeff, G.M., Sutton, C., 2002. Novel ballast water heating technique offers cost-effective treatment to reduce the risk of global transport of harmful marine organisms. Marine Ecol. Progress Series 191, 289-293.

Rincon, A.-G., Pulgarin, C., 2004. Bactericidal action of illuminated $\mathrm{TiO}_{2}$ on pure Escherichia coli and natural bacterial consortia: Post-irradiation events in the dark and assessment of the effective disinfection time. Appl. Catalysis B: Environ. 49, 99-112.

Rizzo, L., Belgiorno, V., Napoli, R.M.A., 2004. Regrowth evaluation of coliform bacteria injured by low chlorine doses using selective and nonselective media. J. Environ. Sci. and Health 39, 2081-2092.

Schink, T., Waite, T.D., 1980. Inactivation of $\mathrm{f} 2$ virus with ferrate (VI). Water Res. 14, $1705-1717$.

Scully, F.E., Jr., Hogg, P.A., Kennedy, G., Lewicki, C., Rule, A.M., Soffriti, J.G., 1999. Development of Disinfection-Resistant Bacteria During Wastewater Treatment. Water Environ. Res., 71, 277-281. 
Selleck, R.E., Saunier, B.M., Collins, H.F., 1978. Kinetics of bacterial deactivation with chlorine. J. Environ. Eng. 104, 1197-1212.

Sohn, J., Amy, G., Cho, J., Lee, Y., Yoon, Y., 2004. Disinfectant decay and disinfection by-products formation model development: chlorination and ozonation byproducts. Water Res. 38, 2461-2478.

US Environmental Protection Agency, 2001. Aquatic Nuisance Species in Ballast Water Discharge: Issue and Options, Office of Water, Washington, DC http://www.socp.org/ballast/papers/EPA (accessed June 2006).

WEF, 1996. Wastewater Disinfection: Manual of Practice FD-10. Water Environment Federation.

Western Oregon University, 2006. Pourbaix Diagrams. www.wou.edu/las/physci/ch412/pourbaix.htm (accessed March 2006).

White, C.G. 1999. Handbook of Chlorination and Alternative Disinfectants, $4^{\text {th }}$ ed. John Wiley \& Sons, NY.

Wood, R.H., 1957. The heat, free energy and entropy of the ferrate (VI) ion. J. Amer. Chem. Soc. 80, 9, 2038-2041. 
Xie, Y.F., 2004. Disinfection Byproducts in Drinking Water: Formation, Analysis, and Control. Lewis Pub.: NY, NY. 